UNIVERSIDADE DE SÃO PAULO

FACULDADE DE FILOSOFIA, LETRAS E CIÊNCIAS HUMANAS DEPARTAMENTO DE LETRAS MODERNAS

PROGRAMA DE PÓS-GRADUAÇÃO EM ESTUDOS LINGÜÍSTICOS E LITERÁRIOS EM INGLÊS

CARLOS RENATO LOPES

\title{
Lendas Urbanas na Internet: entre a ordem do discurso e o acontecimento enunciativo
}

São Paulo

2007 


\section{Lendas Urbanas na Internet: entre a ordem do discurso e o acontecimento enunciativo}

Tese apresentada ao Programa de

Pós-Graduação em Estudos Lingüísticos e Literários em Inglês do Departamento de Letras Modernas da Faculdade de Filosofia, Letras e Ciências Humanas da Universidade de São Paulo, para a obtenção do título de Doutor em Letras.

Orientadora: Prof ${ }^{a}$. Dr ${ }^{\mathrm{a}}$. Anna Maria G. Carmagnani

São Paulo

2007 
BANCA EXAMINADORA 
Para minha mãe, meu irmão, e em memória do meu pai

"Procur[emos]... testemunhar da única coisa que conta[:] a infância do encontro, o acolhimento feito à maravilha que acontece (qualquer coisa), o respeito pelo acontecimento. Não te esqueças de que foste e és, tu próprio, isso, a maravilha acolhida, o acontecimento respeitado, a infância misturada dos teus pais." - J.- F. Lyotard, “Glosa sobre a resistência”, 1986 


\section{AGRADECIMENTOS}

A Anna Maria Carmagnani, minha orientadora desde o Mestrado, pelo estímulo, respeito e amizade de sempre.

À CAPES pelo auxílio da bolsa.

Aos colegas da USP, de hoje e de há muito tempo, pela amizade e trocas sempre prazerosas.

Aos meus professores da área de Estudos Lingüísticos e Literários em Inglês, que muito me inspiraram (e continuam inspirando) por suas idéias e seu exemplo.

Aos amigos e familiares que, mesmo de longe, transmitiram sempre seu carinho.

Aos que compartilharam comigo, direta ou indiretamente, o interesse por essas narrativas estranhas e fascinantes.

E, como não poderia deixar de ser, aos sujeitos por trás das práticas, esses meus conhecidos desconhecidos. 


\section{RESUMO}

Este trabalho é dedicado ao estudo de narrativas do gênero lendas urbanas dentro de uma perspectiva discursiva. Com base em um corpus composto de mensagens trocadas em uma comunidade virtual sobre o tema na Internet no período entre 2005 e 2006, busca-se fundamentalmente investigar os modos pelos quais tais narrativas se situam, enquanto enunciados, entre uma ordem de discurso dotada de uma certa sistematicidade e uma instância de acontecimento único, materializada na enunciação.

Propõe-se a reflexão de que as lendas urbanas, sendo geradas no seio da vida cotidiana e trazendo elementos que fazem parte desse cotidiano de um modo bastante acessível - embora em muitos casos representando ameaças novas e impensadas -, configuram-se como narrativas que reelaboram velhos enredos (ou intrigas) da experiência social em combinações potencialmente variadas, multiplicando-se, assim, as possibilidades de formulação de acontecimentos enunciativos dentro de uma estrutura mais ou menos estável e reconhecível. A ênfase na dimensão de prática discursiva em que as lendas se materializam - sendo elas retomadas, contestadas, (re)contextualizadas no interior dessa prática - revela o modo como tais narrativas se entretecem em uma rede particularmente heterogênea, freqüentemente polêmica, na qual antigos medos, ansiedades e apreensões sociais são articulados e na qual os sujeitos envolvidos são confrontados com seus pressupostos de verdade e relações de poder/saber.

A partir das análises empreendidas, conclui-se que a tensão dialética entre regularidade e singularidade - ou, de forma mais geral, estrutura e acontecimento - se encontra na base mesma das práticas discursivas estudadas, manifestando-se em diferentes níveis de análise e sob uma multiplicidade de formas, que vão desde a definição do gênero lenda urbana, passando pelos movimentos de arquivamento e atualização das narrativas, até as representações identitárias construídas e reencenadas pelos textos.

Palavras-chave: lendas urbanas; discurso; narrativa; verdade; identidade 


\begin{abstract}
This thesis is dedicated to the study of the genre of narratives known as urban legends from a discursive perspective. Based on a corpus composed of messages exchanged in a virtual community on the Internet between 2005 and 2006, we aim at investigating the ways in which these narratives are situated, as utterances, between a discursive order which is marked by a certain regularity and the domain of the single event which is materialized through enunciation.

We argue that urban legends, being generated in the midst of daily life and carrying elements that are part of this daily life in an acessible form - although in many cases enacting new and unexpected threats -, present themselves as narratives which reelaborate certain ancient plots of social experience into potencially varied combinations, thus enabling the multiplication of possible formulations of enunciative events within a more or less stable and recognizable structure. An emphasis on the discursive practice dimension through which the legends are materialized - their being recovered, contested, (re)contextualized in the space of such practice - reveals how those narratives are woven into a particularly heterogeneous and often polemical network, in which old social fears, anxieties and apprehensions are articulated and in which the subjects involved are confronted with their assumptions on truth and power/knowledge relations.

From the analyses conducted, we conclude that the dialectical tension between regularity and uniqueness - or, more generically, between structure and event - can be found at the very basis of the discursive practices under scrutiny, manifesting itself on different levels of analysis and in a multiplicity of forms, which include the definition of the urban legend genre, the movements of archiving and updating of legends, and the identity representations that are built and re-enacted in the texts.
\end{abstract}

Key words: urban legends; discourse; narrative; truth; identity 


\section{ÍNDICE}

INTRODUÇÃO 1

PARTE I - Lendas Urbanas, Narrativa e a Questão da Verdade 13

CAPÍTULO 1: Em Busca do Gênero Lenda Urbana 13

1. Definições e Questões de Gênero 13

1.1. Definições dos Folklore Studies 14

1.2. Rumores e Faits Divers 24

1.2.1. Lenda ou rumor? 24

1.2.2. Lenda ou fait divers? 26

1.3. Desconstruindo o conceito de gênero 28

2. Condições de Produção: As Lendas Urbanas na Ordem do Discurso 30

2.1. Procedimentos de Exclusão Externos 31

2.1.1. O tabu do objeto 32

2.1.2. O ritual da circunstância 36

2.1.3. O direito de quem fala (escreve) 37

2.2. Procedimentos de Exclusão Internos 39

2.2.1. O comentário 39

2.2.2. O autor 40

2.3. Procedimentos de Seleção dos Indivíduos 41

2.3.1. As "sociedades do discurso" 41

2.3.2. Os rituais 44

2.3.3. A apropriação social dos discursos 46

CAPÍTULO 2: Narrativas entre a Estrutura e o Acontecimento 48

1. Lendas Urbanas como Narrativa $\quad 48$

1.1. Narrativa e História 49

1.2. Narrativa e Canonicidade 52

1.3. Narrativa e Intriga 54

1.4. Lendas em Narrativa $\quad 57$

2. Estrutura e Acontecimento 61

2.1. Estrutura versus Acontecimento? 61

2.2. Estrutura e Acontecimento no Discurso 65

2.3. Estrutura e Acontecimento nas Lendas Urbanas: uma breve retomada 69

CAPÍTULO 3: A Vontade de Verdade $\quad 72$

1. A Verdade em Xeque: da Filosofia ao Discurso 73

1.1. A Verdade Ontológica em Heidegger e a Tradição Metafísica 73

1.2. Nietzsche, Foucault e a Verdade como Vontade 80

1.3. Rorty e a Visão Pragmatista de Verdade 87

2. A Verdade nas Lendas Urbanas 93

2.1. No Rastro do Furacão: construindo um discurso de verdade 93

2.2. “Quem precisa de lendas urbanas?” 102 
CAPÍTULO 4: Lendas Urbanas e as Ameaças do Cotidiano

1. Os Tecno-Medos

1.1. Celulares Explosivos

109

1.2. Em caso de emergência...

2. Dedos, ratos e outros corpos estranhos

2.1. "Garçom, tem um... dedo no meu chilli!"

2.2. Venenos que matam lentamente

2.3. "Leptospirose em Latinha”, ou Uma História Exemplar 124

3. "Shop 'til you drop... dead"

CAPÍTULO 5: Lendas Urbanas em Arquivo: entre o velho e o novo 135

1. The Nigerian Scam - Um golpe sem fronteiras 138

2. Pains and Needles 148

3. Trick or Treat? - Mais e novas "surpresas" 159

CAPÍTULO 6: Lendas Urbanas como Construções do Outro 165

1. A Conexão Mexicana 167

2. Imigrantes Ingratos, Americanos Estúpidos 175

3. Children of the World 184

CONCLUSÃO 195

BIBLIOGRAFIA $\quad 204$

a) Referências bibliográficas 204

b) Obras consultadas 212

APÊNDICE A 216

$\begin{array}{ll}\text { APÊNDICE B } & 218\end{array}$ 


\title{
INTRODUÇÃO
}

\begin{abstract}
"Por metanarrativa, ou grande narrativa, entendo precisamente narrações com uma função legitimante. O seu declínio não impede que milhares de histórias, umas pequenas e outras menos, continuem a ser a trama da vida quotidiana." - J.-F. Lyotard, O Pós-Moderno Explicado às Crianças, 1986
\end{abstract}

Pesquisar lendas urbanas é deparar-se com um universo vasto de histórias inusitadas. É lidar com casos tão disparatados quanto os que envolvem roubos misteriosos de órgãos humanos para transplante; contaminação por fornos de microondas e telefones celulares cancerígenos; correntes pedindo ajuda para salvar crianças com leucemia; aparições de imagens de santos em janelas de casas; golpes em estacionamentos de shoppings e hipermercados; ou mensagens demoníacas escondidas em gravações musicais.

As chamadas lendas urbanas, ou lendas contemporâneas, parecem fazer parte de nosso cotidiano. Elas nos chegam em conversas com pessoas em que confiamos (ou não), nos jornais sensacionalistas e também nos mais sérios, nos e-mails encaminhados por dezenas de remetentes anteriores de quem nunca ouvimos falar, e até mesmo em filmes e outros produtos populares da mídia. Elas nos alcançam quando menos esperamos e, em alguns casos, mais do que provocar espanto ou surpresa, geram incredulidade e irritação, especialmente quando inundam nossas caixas de mensagens de correio eletrônico.

O que talvez terá sido meu primeiro contato com uma lenda urbana - embora à época nem desconfiasse que se pudesse chamar tal história de "lenda”, ou "urbana”me soou mais como uma história estritamente local: a de uma tal "loira do banheiro" que assustava as crianças da escola onde eu cursava o ensino básico. Em sua versão mais comum, tratava-se da aparição do fantasma de uma moça loira muito bonita, toda vestida de branco, com chumaços de algodão ensangüentados enfiados no nariz e os pulsos cortados, no banheiro feminino da escola onde anos antes havia se matado vítima da paixão não correspondida por um professor. Na verdade, a razão do suicídio pouco importava diante do pânico que a simples idéia de encontrar um fantasma no banheiro provocava entre as crianças, especialmente as meninas. Essas se recusavam a ir ao banheiro desacompanhadas, pois sabiam que, se assim o fizessem, teriam uma grande chance de se confrontar com a dita aparição. 
Anos mais tarde, já lecionando em escolas superiores na cidade de São Paulo, tive a oportunidade de constatar que vários de meus alunos, a maioria bem jovens, entre seus 18 e 20 e poucos anos, não só já tinham ouvido falar da história da "loira do banheiro" como também sabiam de detalhes a acrescentar ou corrigir. Talvez eu não imaginasse que essa história fosse de fato restrita à escola primária que freqüentara, mas não deixei de me surpreender com a possibilidade de ela ter sido fabricada muito longe dali, de ter atravessado gerações diferentes e, principalmente, de seu "recontar" ter despertado tamanho entusiasmo, semelhante ao de quem relembra momentos emblemáticos de um tempo um tanto remoto ${ }^{1}$.

Desde já, o episódio suscita a reflexão de como narrativas desse tipo habitam o nosso imaginário de modo intenso, ainda que de formas distintas. E assim me remeto à proposição do teórico alemão Walter Benjamin, em meados do século passado, segundo a qual a narrativa estaria em vias de se acabar, que "a arte de narrar está definhando porque a sabedoria - o lado épico da verdade - está em extinção” (1936/1987: 200-1). Mas talvez tão lugar-comum quanto essa "sentença de morte" nos tenha soado ao longo dos anos deva ser a idéia oposta de que a narrativa vive, sim, nas culturas e nas formas como as sociedades se conhecem e reconhecem. Outro filósofo, o francês Paul Ricoeur, aponta 50 anos depois para o fato de novas formas de narrar estarem nascendo, as quais não sabemos ainda dominar, mas que atestam o poder de metamorfose da função narrativa. E conclui: "Não temos qualquer idéia do que seria uma cultura em que não se soubesse mais o que significa narrar." (Ricoeur 1984/1995: 46). Mais ou menos na mesma época, diria ainda Michel de Certeau, aproximando a questão um pouco mais do tipo de narrativa de que trata este trabalho: "De manhã à noite, as narrativas assombram constantemente as ruas e prédios. Elas articulam nossa existência nos ensinando como esta deve ser. Elas 'cobrem o evento', quer dizer, fazem dele nossas lendas (legenda, aquilo que deve ser lido e dito)” (Certeau 1980/1988: 186)².

Dizer que a narrativa vive é, de fato, testemunhar que as formas de cultura popular, em especial aquelas que nos chegam pela mídia, ocupam lugar de destaque na construção das nossas identidades e relações sociais.

\footnotetext{
${ }^{1}$ A respeito dessa questão, a folclorista norte-americana Linda Dégh (2001: 52) esclarece que, ao contrário do que a dicotomia pode sugerir, as lendas são ao mesmo tempo locais e "migratórias". Afinal, como pode uma comunidade garantir que o repertório que compartilha seja único e local, e não algo potencialmente conhecido por outras comunidades? De qualquer maneira, a lenda local é local nos termos daquela comunidade em questão, por mais que ela tenha "migrado" na experiência de quem a estuda.

${ }^{2}$ São minhas todas as traduções de citações de obras consultadas originalmente em inglês e francês.
} 
Os estudos acadêmicos que levam em conta esse papel importante da cultura popular já há algumas décadas têm se dedicado, se não às formas narrativas clássicas que Benjamin julgava agonizantes com a ascensão do romance, a "novas” experiências narrativas, de natureza mais fragmentada, afiliadas a gêneros e formatos diversos para as quais apontavam Ricoeur e Certeau. Ainda que revisitem temas tão antigos à humanidade quanto a aparição de fantasmas, essas “novas” experiências dão alento continuado à arte de narrar.

Por arte de narrar entendo aqui não somente a tradição oral de transmissão de histórias, mas também - e principalmente neste trabalho - uma forma contemporânea de contar histórias em rede, que encontra na Internet seu meio mais bem acabado. Foi observando como as lendas urbanas encontraram na Internet um ambiente profícuo de transmissão e re-transmissão que percebi aí um rico potencial de pesquisa e investigação. Foi pensando também como essas histórias fazem parte do cotidiano das pessoas de modo um tanto difuso, mas ainda assim constante o suficiente para reaparecer ora e vez em produtos da mídia, em conversas informais e, sobretudo, num universo de referências culturais de jovens educandos com quem trabalho, que acreditei ser justificável um estudo aprofundado dessas narrativas em uma tese de doutorado.

Haveria, além dessas justificativas, o fato de que no Brasil, pelo menos até onde tenho conhecimento, não existem trabalhos publicados exclusivamente sobre o tema. Se eles existem, de qualquer maneira, não o abordam sob uma perspectiva de linguagem e discurso. Ainda assim, o espaço acadêmico atual me parece aberto a investigações dessa natureza. As formas de linguagem contemporâneas, ricas em suas sempre novas (e reformuladas) configurações, em seus sempre metamorfoseados gêneros, impõem desafios constantes ao pesquisador que se aventura nessa empreitada. Talvez essa abertura tenha sido possibilitada sob a credencial dos estudos de mídia que têm sido feitos nos últimos anos aliando as contribuições de linhas de investigação crítica da linguagem - entre elas a Análise do Discurso de linha francesa - ao pensamento teórico vindo de outras áreas como a sociologia, a psicologia social, a antropologia, a filosofia e os estudos de cultura e comunicação.

Particularmente dentro da área de estudos lingüísticos em inglês, em que se situa esta minha pesquisa, penso que o trabalho se justifica em pelo menos dois aspectos. Um primeiro aspecto está relacionado ao universo de referência cultural dos países de língua inglesa, em que as lendas se inscrevem em um repertório de narrativas 
populares/midiáticas mais imediatamente identificável e acessível por uma memória de discurso (relativamente) recente. Conforme aponta o folclorista norte-americano Jan Harold Brunvand em sua Encyclopedia of Urban Legends (2002: xvii), as lendas urbanas na virada do milênio já haviam migrado em larga escala de uma tradição oral de folclore para um universo de pop culture, onde se tornaram "estereotipadas, padronizadas, exploradas, comercializadas e repaginadas” de inúmeras formas, tendo na Internet seu meio de circulação privilegiado. No Brasil, no entanto, não são muitas as pessoas capazes de identificar de imediato o que seja uma lenda urbana, o que pude evidenciar cada vez que tive que explicar de que tratava o meu objeto de pesquisa.

Um segundo aspecto que justifica a vinculação - e talvez mais significativo para nós aqui - tem a ver com a proposta de analisar mais de perto as lendas em que figura o elemento do “estrangeiro”, do “outro”, como articulando a construção da identidade do “um”. É o caso, por exemplo, das histórias em que imigrantes ilegais - ou qualquer outro elemento que remeta à presença do estrangeiro na sociedade - representam uma suposta ameaça à segurança e à unidade identitária do elemento local. A idéia aqui seria relacionar, de maneira mais ampla, as lendas enquanto discurso à sua exterioridade sócio-histórica, o que nos poderia fornecer um insight sobre o estado atual de nossa cultura e sociedade, como já sugeria Brunvand há mais de 25 anos (1981: 2) em uma das obras pioneiras publicadas sobre o tema.

Mas uma questão logo se impõe: que tratamento dar às lendas urbanas, isto é, como recortar esse material e iluminá-lo de um modo original dentro de um trabalho acadêmico como este? Na tentativa de abordar essa questão, parto, antes de mais nada, do princípio de que se deve olhar para as lendas como práticas discursivas, dotadas de regularidades próprias, mas cuja instanciação não se dá sob a forma de textos fechados, estabelecidos de uma forma única e fixa. Dentro dessa perspectiva, alinho-me com a posição teórica de Orlandi (2001) segundo a qual o texto é um local privilegiado de escuta dos processos discursivos que, no entanto, não se iniciam nem se encerram nele. O texto é porta de entrada material para se vislumbrar a maneira como o discurso se filia a uma memória do dizer - aqui, no nosso caso, uma memória constituída pelo que já se disse e se escreveu sobre lendas urbanas -, ao quê e ao como já se contou. O texto, dentro dessa perspectiva, materializa a memória e deve ser visto em seus mecanismos de construção de sentido, e não meramente como o reflexo de uma realidade que lhe é 
exterior. Como aponta a autora, o texto é parte de um processo discursivo abrangente e, assim sendo,

"Uma vez atingido [por meio da análise] o processo discursivo que é o que faz o texto significar, o texto, ou os textos particulares analisados desaparecem como referências específicas para dar lugar à compreensão de todo um processo discursivo do qual eles - e outros que nem mesmo conhecemos - são parte. Não são pois só aqueles textos os responsáveis pelos processos de significação que se atinge, e eles não estão tampouco relacionados só aos processos que eram objeto de sua análise. Eles são matéria provisória da análise.” (Orlandi 2001: 89)

Assim como não haveria “a” versão definitiva da lenda da loira do banheiro - o que se atesta pela variação de detalhes e circunstâncias em torno dessa mesma história -, não podemos dizer tampouco que as coletâneas de lendas urbanas disponíveis em publicações organizadas por estudiosos do folclore contenham versões definitivas das histórias. Como veremos no Capítulo 1 a seguir, as lendas urbanas, diferentemente de narrativas populares tais como as lendas tradicionais ou os contos de fada, se estabelecem sob a forma de confronto de versões, de reiterações ou mesmo retificações de versões anteriores, sempre recontadas, sempre retornando à baila ou, nos termos da discussão teórica suscitada por Orlandi, reavivando a memória de um dizer.

Não somente isso: as lendas urbanas, especialmente pelo modo como são articuladas na mídia eletrônica, se materializam em meio a práticas argumentativas nas quais se debatem, (re-)afirmam, ou contestam seus conteúdos e suas formas. De fato, as lendas urbanas - e essa é uma das teses que buscarei sustentar ao longo deste trabalho são práticas sócio-discursivas descontínuas e multiformes, geradas em um configuração interdiscursiva particularmente heterogênea a qual se constitui por meio de processos freqüentemente polêmicos, e na qual sujeitos se confrontam diretamente com seus pressupostos de verdade e relações de poder/saber.

Em especial, buscarei investigar, a partir do corpus coletado, como a tensão entre estrutura e acontecimento se manifesta no gênero lenda urbana de diferentes formas e em diversas frentes, articulando, entre outras dualidades, a do símbolo e o signo, o dado e o criado, a contingência e a necessidade, o arquivado e o arquivar. A 
tensão entre estrutura e acontecimento constitui-se, pois, desde já, um fio condutor que norteará este trabalho.

O título Lendas Urbanas na Internet: entre a ordem do discurso e o acontecimento enunciativo sumariza a orientação constante, ao longo de todo o trabalho, de explorar esse movimento que parte, de um lado, daquilo que se inscreve numa ordem do discurso, isto é, na ordem das regularidades e repartições de sentido em configurações discursivas relativamente estáveis a, de outro, aquilo que se constituiu no momento único da produção e/ou circulação das lendas em suas diferentes versões, nos sucessivos comentários a seu respeito, nas suas sucessivas retomadas e re-significações.

Em vista dessas questões preliminares, proponho a seguinte hipótese geral para este trabalho: as lendas urbanas são narrativas multiformes e heterogêneas, materializadas em práticas discursivas localizadas, por meio das quais antigos medos e apreensões sociais são (re)articulados sob a forma do "novo" e nas quais as crenças dos sujeitos envolvidos a respeito do que é ou não "verdadeiro" são (re)encenadas.

A definição do corpus está diretamente ligada à elaboração dessa hipótese, na medida em que os textos que o compõem funcionam, em sua dimensão de prática discursiva, como terreno de exploração potencial das questões levantadas. Gostaria, portanto, de discutir em algum detalhe minha escolha do corpus a partir de uma fundamentação teórica.

Inicio por reconhecer o risco, apontado por Michel Pêcheux de, ao inscrever-se um tal discurso em uma dada série (no caso, uma série de lendas urbanas), “absorver o acontecimento desse discurso na estrutura da série na medida em que esta tende a funcionar como transcendental histórico, grade de leitura ou memória antecipadora do discurso em questão" (1983/1997: 56). É preciso reconhecer o corpus como um recorte, não como uma grade de leitura, o que apenas contribuiria para reforçar o discurso em sua dimensão de regularidade estrutural, apagando-se sua dimensão de acontecimento. Ora, conforme já sugeri, o que este trabalho pretende fazer é explorar justamente a tensão constante que se estabelece entre essas duas dimensões.

Como aponta Gregolin, a proposta de Pêcheux, formulada em seus últimos escritos a partir de uma releitura de Michel Foucault, representa uma mudança paradigmática no percurso teórico da Análise do Discurso de linha francesa, uma vez que passa a colocar a questão da escolha do corpus não mais a partir de um saber histórico exterior - um momento inaugural ou uma decisão definitiva - mas de um saber 
construído "no interior mesmo do campo discursivo, na imensa circulação de enunciados” (Gregolin 2004: 180). É por isso que não se deve falar, nesse quadro de referência, em um arquivo de ordem fixa, mas antes em "estados de corpus" que permanentemente se reconfiguram, como que em forma de espiral, articulando o lingüístico e o discursivo. Com efeito, não é possível se pensar em um arquivo fixo de lendas urbanas, a não ser para fins meramente de compilação. Minha proposta é trabalhar dentro dessas práticas os espaços contraditórios que reforçam e ao mesmo tempo redefinem as próprias condições de existência dessas narrativas, mais do que propriamente explorá-las sob o ponto de vista dos temas evocados.

Demarcadas essas primeiras balizas teóricas, compus o corpus de base para este trabalho a partir de dois conjuntos de textos:

a) Lendas urbanas apresentadas, comentadas e discutidas em uma lista de discussão na Internet - urban-legends@yahoo.com, ligada ao site www.snopes.com - dedicada exclusivamente ao tema, da qual faço parte desde março de $2003^{3}$. Num primeiro momento, propus aqui um recorte meramente cronológico, englobando todas as mensagens recebidas durante o ano de 2005, aproximadamente 7200. A partir daí efetuei um segundo recorte, contendo 1412 mensagens, com base em dois critérios: (i) mensagens que remetessem, de alguma forma ou de outra, a alguma questão ou tema recorrentes já identificados em lendas urbanas conhecidas e que aqui sofrem uma reatualização, ou pelo menos, suscitam um debate mais estendido; e (ii) mensagens que apontam para o próprio fazer das lendas urbanas como prática mediada dentro de um veículo de discussão; isto é, mensagens que se referem aos próprios limites do processo discursivo, questionando sua legitimidade, sua relevância, sua própria dispersão como forma de discurso. Mais fluidos do que se possa imaginar, esses dois critérios permitiram a inclusão de mensagens de natureza bastante diversa, as quais freqüentemente se encaixam tanto em um quanto em outro grupo. Posteriormente, tendo delineado a organização dos capítulos de análise, procedi a mais um recorte, estabelecendo, assim, o corpus final em 751 mensagens, das quais 614 vieram diretamente daquele segundo recorte, e outras 137 complementares foram coletadas do conjunto de mensagens que continuei a receber e arquivar ao longo de 2006, já durante

\footnotetext{
${ }^{3}$ Em mensagem de 17 de outubro de 2005, Barbara Mikkelson, co-fundadora e moderadora do site, informa, em resposta a um membro da lista, que esta contava, na época, com pouco mais de 1200 inscritos.
} 
o processo de escrita. Longe de ser um conjunto homogêneo de textos, tal corpus apresenta-se sob os mais variadas formatos: ele inclui desde uma simples indicação de um link para um texto jornalístico que o autor julga relevante, ou o relato de casos anedóticos associados a determinada questão do momento, até longas séries (ou threads) de debates entre os membros da comunidade virtual - debates esses em que não raro figuram assuntos paralelos ou completamente alheios aos conteúdos das lendas em si. Destacam-se, entre outras, todas as mensagens recebidas no período referindo-se ao uso de telefones celulares - incluindo a polêmica sobre seus possíveis riscos -, bem como as que tratam de casos envolvendo suposta contaminação ou adulteração de produtos alimentícios consumidos em lojas e restaurantes, e também as que implicam a presença do fator "estrangeiro”, como sugeri acima ser essa uma das análises que privilegiarei no trabalho (ver Capítulo 6). Porém, insisto: mais importante que os temas é como esse corpus materializa as práticas discursivas, em especial as configurações identitárias e de poder/saber que a elas subjazem. Pela riqueza desse material, e em consonância com o pressuposto de que as lendas urbanas não são textos fechados, mas sim instâncias de uma prática, recorro a essa seção do corpus como material de base para a maior parte das análises conduzidas ao longo do trabalho.

b) Lendas urbanas que me chegam por e-mail desde 2001, de remetentes conhecidos ou não, boa parte das quais se tornaram referências - e em alguns casos verdadeiros clássicos instantâneos - do gênero em publicações recentes. Incluem-se aqui alertas contra o uso de desodorantes cancerígenos, contaminação por urina de rato em latinhas de bebida e golpes para obtenção de dinheiro fácil, para citar alguns exemplos. Também entram nesse grupo paródias de lendas urbanas, que já vêm figurando como capítulo à parte em algumas coletâneas ${ }^{4}$. Essas lendas serão usadas como apoio às análises do corpus na Parte II deste trabalho. De um total de aproximadamente 140 mensagens recebidas no período, selecionei 13 , cada qual contendo uma lenda diferente, em vista dos temas já determinados pela escolha das mensagens em a) acima.

No intuito de melhor justificar minha escolha de delimitar o corpus a um conjunto de mensagens transmitidas pela Internet (e não oralmente, como poderia também ser o

\footnotetext{
${ }^{4}$ Dentre tais compilações, que contam já com uma certa freqüência de publicação em países de língua inglesa, especialmente nos Estados Unidos, destacam-se as enciclopédias e coleções por temas editadas por Vos (1996), Genge (2000), Brunvand $(2001$; 2002) e Roeper (2002). Em francês, destaca-se Campion-Vincent \& Renard (2002)
} 
caso), julgo relevante lembrar aqui o que diz Foucault a respeito dos aparatos institucionais e técnicos e sua contribuição decisiva para o formato com que os discursos transitam em nossa sociedade:

“As práticas discursivas não são pura e simplesmente modos de fabricação de discursos. [Elas] ganham corpo em conjuntos técnicos, em instituições, em esquemas de comportamento, em tipos de transmissão e de difusão, em formas pedagógicas, que ao mesmo tempo as impõem e as mantém.” (Resumo do Curso de 1970-1, in: Foucault 1997: 12)

Assim, a noção de que a Internet é o meio de transmissão pelo qual as lendas parecem ter adquirido novo fôlego, como numa espécie de "ressurreição” do gênero, precisa ser posta em consideração. Aplicando o raciocínio de Foucault, deve-se pensar a Internet não simplesmente como um meio "moderno" de se transmitir narrativas, mas sim um meio que impõe características e limites específicos a essa transmissão, os quais devem ser levados em conta como parte integrante da análise das condições de produção/recepção do discurso ${ }^{5}$.

Dentro desse universo de referência, penso na questão das fontes de “verificação” das histórias que circulam na lista de discussão, imediatamente acessáveis por meio de hipertexto, ou a questão do conhecimento prévio (interdiscursivo) que essa comunidade bem restrita de interlocutores - os membros da lista em questão - carregam o tempo inteiro consigo, desde o momento da seleção do que é ou não publicável, até o nível de comentários (ora derrisórios, ora autoritários) sobre a relevância e, como não poderia deixar de ser, a veracidade das histórias.

Ainda que aqui as respostas não se dêem oralmente, durante a transmissão, e sim a posteriori, a partir da leitura das mensagens da lista, acredito que elas ainda refletem traços avaliativos comuns às que as platéias normalmente fazem ao ouvir as lendas. Entre esses traços avaliativos, Bill Ellis (2001: 22) inclui: referências a experiências de outras pessoas confirmando ou negando a validade da lenda, a crítica direta ou indireta das “personagens” envolvidas na história, e o apelo à concordância de outros membros

\footnotetext{
${ }^{5}$ Fernback (2003: 29-30—42) identifica no ciberespaço um local onde se encontram marcas tanto da cultura oral quanto da escrita, o que torna até certo ponto irrelevante a mera distinção do discurso da lenda urbana por via eletrônica entre oral e escrito. Uma característica que a autora reconhece como resultante dessa modalidade híbrida seria a possibilidade de se transmitir, imediatamente e de modo casual e efêmero, uma história que poderia não soar como digna de crédito se contada pessoalmente.
} 
da comunidade. A lista de discussão na Internet constitui, enfim, um suporte complexo para essas práticas também por si só bastante complexas.

Para encerrar esta introdução, passo a uma breve descrição, em forma de prévia, dos conteúdos das partes e capítulos em que se divide o trabalho. Começo por esclarecer que este não está dividido de forma nítida em parte teórica e parte de análise. No entanto, a divisão básica entre as partes aponta para um crescendo, os pressupostos teóricos se delineando na Parte I e as análises se desenvolvendo na Parte II. As análises na Parte II irão, portanto, refletir, sempre que for possível/relevante, as discussões teóricas que terão sido feitas na Parte I, aprofundando conceitos já introduzidos e discutidos numa espécie de efeito espiral. De qualquer maneira, a possibilidade mesma de se pensar as práticas discursivas no espaço intermediário entre estrutura e acontecimento impede que se abordem os textos de modo estanque, como mera ilustração da teoria. Antes, procuro ter em mente, como nos lembra Foucault em seu $A$ Arqueologia do Saber, a dimensão de “acontecimento estranho" dos textos/enunciados com que estou trabalhando. A saber, para o autor o enunciado é

“um acontecimento estranho, por certo: inicialmente porque está ligado, de um lado, a um gesto de escrita ou à articulação de uma palavra, mas, por outro lado, abre para si mesmo uma existência remanescente no campo de uma memória, ou na materialidade dos manuscritos, dos livros e de qualquer forma de registro; em seguida, porque é único como todo acontecimento, mas está aberto à repetição, a transformação, a reativação; finalmente, porque está ligado não apenas a situações que o provocam, e a conseqüências por ele ocasionadas, mas, ao mesmo tempo, e segundo uma modalidade inteiramente diferente, a enunciados que o precedem e o seguem.” (Foucault 1969/2004: 31-2)

Explorar essa “estranheza” em suas múltiplas relações, em suas contradições inerentes, enfim, em sua espessura própria representa a contribuição modesta (mas o desafio maior) a que este trabalho se propõe.

Portanto, aos capítulos. A Parte I se inicia com um capítulo mais geral, buscando entender as lendas urbanas enquanto gênero. Na primeira parte desse Capítulo 1, 
apresento diferentes definições do gênero, conforme ele é discutido pelos estudos do folclore e áreas afins. Na seqüência, confronto tais definições com as de duas formas relacionadas - o rumor e o fait divers - e, finalmente, busco problematizar a própria noção de gênero como forma fixa e estabelecida. Numa segunda parte do capítulo, proponho um levantamento dos mecanismos de distribuição e controle (externos e internos) do discurso que Foucault identifica em A Ordem do Discurso (1971/1996), analisando os mais pertinentes ao nosso objeto de estudo. Esses mecanismos são estudados tanto em seu aspecto mais coercitivo quanto em seu caráter produtivo, com a ênfase recaindo, nesse momento inicial, no primeiro aspecto, uma vez que a preocupação é de delimitar o objeto em sua dimensão de estrutura, ou seja, em suas regularidades específicas. Tal abordagem funciona como um "roteiro" para tratar das lendas urbanas de forma não meramente descritiva ou "conteudística”. Isto é, cada um dos conceitos ali discutidos servirá para delimitar o objeto e explorar suas possibilidades enquanto discurso.

No Capítulo 2, discuto as lendas urbanas sob a perspectiva das teorias de narrativa que aproximam história e ficção - especialmente as propostas por Ricoeur, Sahlins, White e Certeau - e avanço na discussão, já levantada na Introdução e no Capítulo 1 sobre a relação entre estrutura e acontecimento, binômio que irá ser retomado continuamente ao longo das discussões teóricas e das análises do corpus.

Outro aspecto central deste trabalho, a vontade de verdade - a qual constitui também um dos mecanismos discutidos por Foucault em A Ordem do Discurso - ganha um capítulo exclusivo (Capítulo 3), encerrando a Parte I. Aqui a contribuição da filosofia de Heidegger, Nietzsche, Foucault e Rorty é mobilizada na discussão envolvente e inquietante sobre como se constrói a própria idéia de realidade e como essa realidade se propõe como verdade dentro do discurso das lendas urbanas. Ainda nesse capítulo, uma primeira análise de um segmento do corpus é conduzida.

A Parte II, centrada nas análises propriamente ditas, começa com um capítulo (Capítulo 4) que trata das ameaças do mundo contemporâneo, tema que aglutina boa parte das mensagens que compõem o conjunto das análises. Trata-se de investigar como as lendas urbanas articulam discursivamente medos e tensões que os sujeitos percebem como fazendo parte do cotidiano que os cerca.

O Capítulo 5 propõe análises que enfatizam a relação dialética entre o novo e o velho tal como é construída pelas práticas discursivas em torno de três ciclos de lendas 
urbanas. Retomam-se, aqui, as noções de arquivo e suplementaridade na abordagem do discurso enquanto acontecimento enunciativo único e ao mesmo tempo elemento estruturador de uma memória.

No capítulo final (Capítulo 6), a discussão sobre o caráter de acontecimento do discurso avança um pouco mais, propondo-se uma investigação de como as lendas se constituem como um espaço de construção de identidades, especialmente a identidade do outro estrangeiro.

Finalmente, na conclusão, retomam-se as idéias centrais desenvolvidas ao longo dos capítulos em vista de todas as discussões teóricas e análises que foram sendo traçadas até então. Será o momento de avaliar se a hipótese central inicialmente delineada se confirma e, se o faz, de que formas isso se dá.

Espero, assim, que o leitor me acompanhe nesse trajeto como alguém que se dispõe a ouvir uma história que, embora não sendo uma lenda, pretende suscitar interesse e curiosidade semelhantes aos que animam os ouvintes de uma história "boa demais" para ser verdade. 


\section{PARTE I - Lendas Urbanas, Narrativa e a Questão da Verdade}

\section{CAPÍTULO 1: Em Busca do Gênero Lenda Urbana}

"I was warned that I might not see the bottom of my in-box again if I signed up with this group. The bits of lore to be investigated are fun and interesting but what really delights me is to see so many insightful observations and cogent, persuasive arguments. I hope I can return the favor." - R. Cuplin, urban-legends@yahoogroups.com, 2005

"Pat is right - this list is no place for "My God is crunchier and better-tasting than your God" pulpit poundings."

-Barbara Mikkelson, urban-legends@yahoogroups.com, 2005

\section{Definições e Questões de Gênero}

Comecemos com a pergunta: afinal, o que são lendas urbanas? Uma primeira definição, digamos, intuitiva poderia ser formulada nos seguintes termos: são histórias que envolvem elementos ou situações banais do cotidiano, mas que por seu caráter inusitado, ou em muitos casos absurdo, provavelmente não aconteceram. No entanto, são contadas como se tivessem de fato acontecido, não diretamente a seus narradores, mas a alguém por eles conhecido ou a eles ligado. Quando um conhecido nos conta, por exemplo, que alguém foi contaminado por uma agulha infectada com o vírus HIV ao sentar-se numa cadeira de cinema, ou ao enfiar o dedo no lugar de onde saem as moedas de troco em um telefone público, dificilmente saberemos quem é essa pessoa, seu nome, onde mora. Nosso conhecido nos dirá que aconteceu com “um amigo de um amigo”, ou que ouviu contarem isso numa festa, ou ainda, como diriam os americanos, by the water cooler (isto é, em conversa ao redor do bebedouro, ou no cafezinho).

A inclusão de narrativas de natureza tão diferentes quanto as que menciono na Introdução, sob uma mesma categoria a qual estou chamando de "lendas urbanas", sugere que vários elementos e formatos estão em jogo nessa modalidade de prática discursiva. São diversas as tentativas de definir o gênero, e elas vêm de campos de estudo diferentes. De fato, estudiosos do fenômeno vêm há tempos tentando chegar a um denominador comum no que concerne a definição de lenda, tanto em sua versão “tradicional” quanto em sua versão “contemporânea”. Conforme indiquei anteriormente, 
as lendas urbanas são estudadas - particularmente na Europa e na América do Norte dentro da uma área específica chamada folklore studies, mas também em outras áreas, como a sociologia e a psicologia social. Sugiro, portanto, que, num primeiro momento desta seção, olhemos para como esses autores têm buscado definir o gênero, levando em conta o que podemos aproveitar dessas reflexões em nosso trabalho. Em seguida, em vista do corpus selecionado para análise, proponho traçar uma correlação entre lendas urbanas, fait divers e rumores, investigando as semelhanças e diferenças entre esses diferentes gêneros com vistas a uma abordagem mais inclusiva do material que comporá as análises em capítulos posteriores. Finalmente, ainda nesta seção, revejo o conceito de gênero propriamente dito, buscando desconstruir a noção de categoria fechada ou forma estável que se poderia associar ao conceito.

\subsection{Definições dos Folklore Studies}

Antes de mais nada, há o conceito de lenda. Embora já se tenha dito que é impossível definir realmente o que é uma lenda, as tentativas continuam surgindo. Já na década de 1970, o folclorista Robert Georges, consciente desse fato, chegou a propor a involuntariamente engraçada definição de lenda como

"uma história ou narrativa que pode nem mesmo ser uma história ou narrativa; ela se dá em um passado histórico recente que pode ser concebido como remoto ou anti-histórico, ou nem mesmo em um passado; ela é tida como verdadeira por alguns, falsa por outros, e ambos ou nenhum dos dois pela maioria.” (Georges 1971 apud Brunvand 2002: 112)

Mas, se essa definição pode ser interessante pelas próprias contradições que comporta, ninguém parece tê-la levado muito a sério.

Em uma linha mais conciliatória, Linda Dégh (2001) faz um levantamento em ordem cronológica das definições de lenda e lenda contemporânea propostas por estudiosos europeus e norte-americanos no último século, a fim de identificar, para além das discordâncias, alguns elementos de intersecção. 
Revisando a tradição filológica germânica do estudo de lendas, a autora identifica já dois aspectos bastante recorrentes: a crença e o medo, ambos discutidos nos trabalhos de Lutz Röhrich, por exemplo. Esse autor reitera a idéia de que " $a$ lenda demanda do contador e do ouvinte a crença na verdade do que se conta", e que as pessoas contam lendas a fim de "verbalizar ansiedades e medos e, ao explicá-los, liberar-se do poder opressivo de seus medos” (1988 apud Dégh 2001: 37). Elaborando de uma forma mais dialética a noção da crença associada à lenda, Helge Gerndt postula que "as lendas aspiram a ser diretamente ou indiretamente verdadeiras e informar sobre um evento passado verdadeiro", acrescentando: "Uma história se torna uma lenda somente se for apresentada na zona intersticial entre a crença e a dúvida” (1991 apud Dégh op. cit.: 38).

A tradição das abordagens anglo-americanas não revelaria questões substancialmente diferentes, a não ser pela ênfase maior na questão da crença na verdade das narrativas. Como novidade a se destacar, porém, há a inclusão do aspecto social da transmissão e recepção das lendas, assim formulado por Richard M. Dorson:

"Uma vez que se propõem históricas e factuais, [as lendas] devem ser associadas na mente da comunidade com algum indivíduo conhecido, marco geográfico ou episódio particular. Todos ou muitos dos membros de um dado grupo social terão ouvido falar da tradição e podem se lembrar dela de forma breve ou elaborada. Esse é de fato um dos principais testes da lenda: que ela seja conhecida por um número de pessoas unidas em sua área de residência, ocupação, nacionalidade ou crença.” (Dorson 1968 apud Dégh op. cit.: 43)

A problemática da definição, porém, torna-se mais complexa quando entram em cena as lendas contemporâneas. Uma das dificuldades parece ser a de encontrar o que realmente distingue a versão contemporânea da não-contemporânea. Além disso, existe a questão dos vários gêneros e sub-gêneros que são freqüentemente associados à lenda contemporânea. Tall tales, rumors, belief stories, anecdotes, scary stories e bogus warnings são apenas alguns dos exemplos de terminologias que encontramos na literatura.

De qualquer maneira, alguns novos conceitos começam a ganhar ênfase nos esforços definitórios, conceitos que julgo diretamente relevantes ao tipo de análise que 
pretendo fazer aqui. Proponho, então, destacar um conjunto de cinco definições de lenda urbana, ou lenda contemporânea ${ }^{6}$, cada qual enfatizando um aspecto de suas possíveis frentes de abordagem. Analiso as três primeiras de um modo mais geral e as últimas duas em mais detalhe, não com o intuito de fechar questão sobre uma ou outra, mas antes levantar elementos que deverão auxiliar uma investigação de caráter mais discursivo, objetivo a que se propõe este trabalho.

\section{DEFINIÇÃO 1: LENDA EM CONTEXTO}

O sociólogo norte-americano Gary Alan Fine, embora reconhecendo as limitações da tarefa que consiste em descrever formalmente um gênero, propõe uma descrição operacional de lenda contemporânea que comporta alguns elementos que me interessam mais de perto. Para o autor, a lenda contemporânea é

"uma narrativa que um contador apresenta a uma platéia no contexto de seu relacionamento. O texto é um relato de um acontecimento no qual o narrador ou um contato pessoal imediato não esteve envolvido, e é apresentado como uma proposição para a crença; não é sempre tido como verdadeiro pelo falante ou platéia, mas é apresentado como algo que poderia ter ocorrido, e é contada como se tivesse acontecido. As ocorrências são eventos notáveis do tipo dos que são supostamente 'estranhos mas verdadeiros'.” (Fine 1992: 2)

Lendo essa definição com um olhar para as discussões que desenvolverei em capítulos posteriores, destaco, em primeiro lugar, a idéia de que a lenda circula em uma comunidade, isto é, num contexto reconhecível a membros de uma comunidade. Portanto, quem a conta faz parte também dessa comunidade e compartilha com ela suas

\footnotetext{
${ }^{6}$ A propósito, os termos "urbana” e "contemporânea” ambos apresentam problemas. O primeiro se tornou mais popular graças em parte às coletâneas do folclorista Jan Harold Brunvand publicadas desde a década de 1980. Alguns teóricos, no entanto, o rejeitam por acreditar que as histórias não se circunscrevem ao universo das cidades. Já o segundo termo, preferido por autores como Bill Ellis e ratificado pela International Society for Contemporary Legend Research, criada no início dos anos 1990 (Fine 1992: 1), pode levar à falsa impressão de que se trata apenas de histórias recentes, quando muitas delas têm suas raízes em tradições antigas. Em defesa desse termo, porém, há a idéia de que qualquer história é percebida como contemporânea à época em que circula. (Ellis 2001: xiii) Ao longo do trabalho deverei usar os dois termos, mas privilegiarei o primeiro, ainda que consciente de suas limitações.
} 
práticas discursivas e suas regras de funcionamento - regras essas mais ou menos conscientes, mais ou menos anônimas.

A chamada proposição para a crença inclui-se aí nessas regras. Trata-se de um pacto que os membros da comunidade se propõem a fazer, ainda que não tomem como verdadeiras as histórias que fazem circular. Já se tem aí um primeiro questionamento quanto à necessidade da comprovação factual do conteúdo narrado pelas lendas: podemos entender pela sentença final que o supostamente se aplica tanto a elas serem estranhas, quanto verdadeiras. Conforme veremos, essa necessidade racionalizante, que busca apoio em explicações científicas - ou simplesmente de "bom senso" - está na base de grande parte da discussão sobre as lendas por parte da comunidade virtual estudada.

\section{DEFINIÇÃO 2: LENDA COMO RESPOSTA COLETIVA}

A pesquisadora de cultura norte-americana Donna Wycoff também considera a transmissão de lendas como prática dentro de uma comunidade. Sua definição, no entanto, vai mais além, ao afirmar que as lendas contemporâneas:

“... aquelas histórias-rumores de base lingüística, narráveis, apócrifas e geralmente anônimas que relatam eventos relativamente atuais $e$ ostensivamente verdadeiros circulam freqüentemente no interior de uma comunidade como parte de uma resposta coletiva, criativa e inconsciente a alguma questão da comunidade, ainda que codifiquem simbolicamente as ambigüidades sociais que subjazem essa questão.” (Wycoff 1993 apud Dégh 2001: 45)

A autora propõe a idéia de que as lendas articulam questões com as quais a comunidade se vê às voltas para explicar. Podemos aqui interpretar essas questões como sendo medos, ansiedades, polêmicas e interditos que uma sociedade precisa simbolizar, até certo ponto inconscientemente, na forma de narrativas. Essas narrativas viriam então confirmar ou questionar concepções de mundo tidas como válidas dentro da comunidade em questão. A definição de Wycoff dialoga, em certo sentido, com duas outras formulações: a do filólogo e folclorista alemão Lutz Röhrich, já citado acima, e a das estudiosas norte-americanas Mariamne Whatley e Elissa Henken, as quais defendem 
a idéia de que mais importante que a verdade objetiva ou científica por trás da lenda talvez seja “ $a$ 'verdade' que o folclore transmite sobre as atitudes, medos e crenças de um grupo, as quais, por sua vez, moldam e mantêm a identidade daquele grupo" (Whatley \& Henken 2001: 5).

Veremos como essa relação com uma cultura do medo, construída interdiscursivamente, aparece como elemento estruturante de diversas das histórias que compõem o corpus de análise.

\section{DEFINIÇÃO 3: LENDA ENTRE O MUNDANO E O EXTRAORDINÁRIO}

Já o folclorista britânico Paul Smith enfatiza uma outra característica importante da lenda: o fato de estar entre planos de representação. Diz o teórico:

"[A]s lendas contemporâneas se situam em algum lugar entre o mundano, as experiências cotidianas e o extraordinário. Se preferirem, elas dizem respeito ao mundano e o ordinário, porém com um toque inusual. E é sua natureza mundana que fornece a elas uma qualidade única que as diferencia das outras formas de narrativa tradicionais.” (Smith 1995 apud Dégh 2001: 45)

As lendas contemporâneas são, sob esse ponto de vista, histórias ambivalentes, que lidam com elementos imediatamente reconhecíveis e cotidianos (o mundano), mas que estão de algum modo “fora da ordem” (o extraordinário). A idéia remonta a Aristóteles, que em sua Arte Poética já propunha que a narrativa, ao mesmo tempo em que exige um elemento de reconhecimento, algo que nos soa familiar e conhecido - ou "o que faz passar da ignorância ao conhecimento” (s/d: 255) -, também nos apresenta uma reversão, uma mudança no sentido contrário do destino, a chamada peripécia. Na lenda, reconhece-se alguma coisa ao mesmo tempo em que se estranha alguma coisa. Essa característica de estar entre dois planos de representação - o que configura seu caráter único e singular - será explorada mais adiante por um viés análogo e que está na base da hipótese central que norteia o trabalho: a de que as lendas se situam, enquanto práticas discursivas, entre a estrutura (a regularidade, a sistematicidade, relativas à ordem do discurso) e o acontecimento (o particular, relativo à ordem da enunciação). 
Ainda que alguns dos termos propostos exijam uma maior qualificação (em especial, o que Wyckoff chama de “eventos ostensivamente verdadeiros”), nas três definições acima encontramos elementos que concorrem para aproximar, com ênfases e de formas diferentes, o material narrado ("parte de uma resposta coletiva, criativa e inconsciente”), o narrador (“falante”, “contador”) e a comunidade com a qual interage (“seu contexto de relacionamento"). Isso aponta para uma visão mais discursiva do fenômeno das lendas, colocando-as como práticas sociais reconhecíveis ("do mundano e do ordinário”) e compartilhadas por sujeitos sócio-histórico-ideologicamente situados. A abordagem do fenômeno por aqueles autores não se coloca explicitamente nesses termos, mas definitivamente sugere pontes com pressupostos de teorias do discurso que sustentam as discussões que proponho ao longo do trabalho.

Gostaria agora de discutir, mais especificamente, a definição de Bill Ellis (2001) de lendas contemporâneas como formas emergentes e a visão defendida por Linda Dégh (2001) de lenda como gênero dialético. Apresento, na seqüência, os elementos principais dessas propostas.

\section{DEFINIÇÃO 4: LENDA COMO GÊNERO “EMERGENTE”}

Pudemos observar como estudiosos de diferentes áreas começaram nas últimas décadas a definir as lendas urbanas como processos comunicativos, não formas estáticas. Para Bill Ellis, as lendas contemporâneas se constituem como formas emergentes, à medida em que "surgem dentro de contextos sociais os quais elas pretendem alterar" (2001: xiii). Esse caráter emergente das lendas urbanas se dá, segundo o autor, em três níveis.

Primeiro, as lendas urbanas emergem como "notícias fresquinhas” no contexto social de quem as conta. Embora seus temas e sua estrutura possam ser bem antigos, os eventos ou crenças que elas abordam se apresentam como relevantes, na medida em que dizem respeito ao passado, presente e futuro do ouvinte/leitor.

Em um segundo nível, as lendas são emergentes na medida em que seus significados mais elementares derivam de condições e papéis sociais determinados. Consideram-se aqui, por um lado, as razões pelas quais alguém conta uma lenda, e o controle da situação e o poder de transformação de estruturas sociais que essa(s) pessoa(s) podem ou não exercer ao fazê-lo; e, por outro, as expectativas que as platéias têm do evento e o modo como podem influenciar e redirecionar o processo narrativo como um todo. Como bem coloca o autor em um outro momento do texto: 
“As lendas normalmente fazem parte de uma discussão contínua e estão constantemente sujeitas a contribuições, correções, comentários $e$ objeções de outros participantes. Diferentemente dos contos, que em geral são separados de uma conversação normal e ouvidos sem interrupções, as lendas devem ser vistas como parte de um evento comunitário, em que o papel do público é tão importante quanto o dos narradores." (Ellis 2001: 10)

Aqui reforça-se a idéia de que a lenda não é nunca um texto completo, contido em si mesmo, mas sim parte de uma conversa continuada - ainda que na forma escrita, que é o caso que analiso neste trabalho - e, portanto, ela não pode ser descolada das circunstâncias que lhe dão corpo, isto é, de sua performance. Essa performance, motivada pelas preocupações e aspirações locais daquele grupo em que a lenda circula, será mais ou menos longa e detalhada, mais ou menos acalorada, dependendo dos interesses dessa mesma comunidade. Em outras palavras, a "vida” de uma lenda não se limita de uma vez por todas a essa circulação local, mas reinscreve-se sempre, reencenase e toma corpo e voz só mesmo aí num tal espaço, nessa prática discursiva.

Finalmente, as lendas urbanas incorporam um elemento de emergência no sentido de urgência - por exemplo, ao descrever um problema social que precisa de atenção urgente da comunidade. Ainda que esse sentido de urgência tenda a desaparecer à medida em que as "últimas" (mais recentes) lendas vão sendo rapidamente “desbancadas” e outras novas vão surgindo e lhe roubando a atenção, deve-se combater, segundo Ellis, a postura simplista de folcloristas que, ao decretarem de antemão a falsidade das histórias, ignoram aspectos complexos do contexto sócio-histórico em que elas se inserem.

Essa tentativa de trazer o contexto - as condições de produção e recepção - para dentro da própria caracterização do gênero certamente aproxima a tese de Ellis da abordagem discursiva que mobilizarei posteriormente. Assim, explorar as possíveis aproximações entre essas posições teóricas se coloca desde já como uma tarefa promissora. 


\section{DEFINIÇÃO 5: LENDA COMO DIALÉTICA}

Igualmente instrumental é a proposição de Linda Dégh de "lenda" - termo abrangente que ela prefere usar para suas diferentes versões - como gênero "conversacional, dialético e polifônico" por definição (2001: 2). Para a autora, a lenda, mais que qualquer outro gênero do folclore, só pode fazer sentido dentro de um fogo cruzado de controvérsias. Ainda que os interlocutores não expressem particularmente nenhuma resistência ou discordância em relação à proposição da lenda, a já esperada voz opositiva da sociedade se faz sentir de um modo ou de outro. Quando, por exemplo, um narrador descreve uma situação extraordinária ou paranormal, ele tem uma certa consciência das resistências e objeções que poderá gerar na platéia e, assim, pode antecipar em sua formulação uma contra-argumentação (algo como "Eu sei que é difícil acreditar nisso, mas tal fato realmente ocorreu...”). Tal resistência pode até mesmo não ser verbalizada diretamente por membros da platéia (ou ser expressa por outros meios), mas ela existirá sempre em estado potencial.

Dégh coloca a disputa - o "ressoar de opiniões contrárias" - não apenas como mais um elemento da lenda, mas sim sua própria razão de ser. Em suas palavras:

"Toda afirmação que contraria noções tidas como racionais ou autênticas, ou crenças que são canonizadas e portanto quase racionais, traz em si sua própria dialética. Essa antecipação incorporada da contradição é o principal identificador da lenda, distinguindo-a de outros gêneros do folclore.” (Dégh 2001: 2)

Ora, torna-se visível aqui o nexo existente entre essas idéias e os princípios do dialogismo do teórico russo Mikhail Bakhtin (1934-5/1990; 1952-3/2000). Conforme sugerido por esse autor, todos os gêneros são dialógicos no sentido de que "conversam entre si”, incorporando marcas de seu exterior em seu interior de modo constitutivo. Isso equivale a dizer que em todo enunciado é possível ver ressoar, de modo mais ou menos perceptível, as palavras do outro, com as quais ele vem estabelecer uma relação de dialogismo. Além disso, a relação de alteridade se dá não apenas entre um enunciado e os que o precedem, mas também entre um enunciado e os que lhe sucedem na cadeia da comunicação verbal.

De fato, o domínio que os falantes aprendem a ter dos diferentes gêneros do discurso ao longo da vida lhes permite moldar suas falas às formas desses gêneros, isto 
é, adaptar-se à sua extensão, entonação ou gravidade. Ao mesmo tempo, isso só pode ocorrer se se levar em conta o outro e o porvir de sua resposta. Assim, o gênero "lenda” conforme definido por Dégh revela de maneira explícita a relação dialógica, na medida em que ele se sustenta na alteridade, ou seja, traz para si já anunciada a voz do “outro”esse outro que no fluxo da cadeia de comunicação se opôs ou irá se opor a ele, nem que seja para acrescentar uma nova contribuição ou versão recontada da “mesma história”.

Avançando nessa discussão sobre o gênero, retomo aqui o pensamento de Ellis a respeito da performance das lendas para traçar uma conexão entre sua definição e a de Dégh logo acima. Trata-se de reconhecer o fato de que as práticas discursivas em que emergem e circulam as lendas urbanas podem, elas mesmas, ser bastante variadas. As lendas podem estar encaixadas em uma conversa cujo tema principal não seja a lenda propriamente dita; podem vir na forma de um "conto de precaução” (cautionary tale); podem suscitar uma ação imediata, como no caso das correntes via Internet; ou podem ainda se resumir a uma espécie de "lenda-rumor", algo na linha de "Você sabia que essa canção dos Beatles, quando tocada ao contrário, revela uma mensagem demoníaca anunciando a morte de Paul McCartney?” ou “Os hambúrgueres do McDonald’s não são feitos de carne bovina, mas de minhoca”. Conforme aponta Ellis, não existem histórias "básicas”, subjacentes em uma estrutura profunda, a partir das quais vão surgindo versões diferentes, mas sim um conjunto ilimitado de possíveis narrativas com o qual o intérprete (seja ele o estudioso, o contador de histórias, ou a própria platéia) pode vir a associá-las. E acrescenta:

"O que é mais importante, existe também um conjunto ilimitado de narrativas possíveis que cada uma das partes poderia construir no futuro em resposta a essas narrativas existentes. Isso quer dizer que o que quer que proponhamos como sendo 'uma lenda' não é uma trama subjacente mas sim um ímpeto social de criar novas narrativas no formato das antigas." (Ellis 2001: 8)

Isso vem mais uma vez afirmar a idéia de que o estudo de tais narrativas não se deve ater a textos fechados, isto é, versões estruturadas ou resumidas de histórias tal como são apresentadas por folcloristas nas enciclopédias do gênero. Como toda narrativa, de resto, as lendas urbanas devem ser estudadas como performances em 
processos sócio-discursivos, com atenção especial aos mecanismos de produção/recepção que as permitem circular, aos elementos contingenciais de sua enunciação, bem como às questões ideológicas indissociáveis desses processos. Segundo Dan Ben-Amos, o folclore, domínio no qual o estudo das lendas tradicionalmente se situa, não se pode resumir a um amontoado de textos impressos tomados isoladamente e em abstrato, mas sim deve ser visto como um processo comunicativo localizado em um contexto cultural determinado. Dentro dessa perspectiva, nos diz o autor, “a narração é a narrativa; portanto, o narrador, sua história e seu público estão todos relacionados entre si como componentes de um único contínuo” (1972 apud Ellis 2001: 4).

Com efeito, a prática de contar e discutir lendas urbanas nos posiciona como sujeitos cujo papel vai além do julgamento imediato da veracidade ou falsidade das histórias. Essa prática pode nos ajudar a perceber, conforme sugerido na definição 2 acima, o que é que em nosso “mundo cotidiano” tanto mobiliza a circulação de tais histórias; perceber que anseios, que preocupações e que questões estão em jogo; perceber, enfim, que discursos estão sendo construídos e (re)afirmados através dessas histórias. O que leva Ellis (op. cit.: 11) a propor uma abordagem do gênero que me inspira particularmente para a realização deste trabalho. Sugere o autor que perguntemos não que fórmulas as lendas contêm mas o que essas fórmulas corporificam. Isso implica responder à questão: $\mathrm{O}$ que as pessoas estão fazendo quando contam lendas? Certamente não estão simplesmente trocando histórias curiosas ou inusitadas de maneira inocente. Estão compartilhando visões sobre eventos que reconhecem como fazendo parte significativa do mundo que habitam, ainda que de modo potencial ou especulativo. Daí que as narrativas - incluídas as lendas urbanas "sobrevivem em parte porque elas nos lembram do que sabemos e em parte porque elas nos chamam de volta para aquilo que nós consideramos significativo” (Fulford 1999: 3).

Linda Dégh vai mais longe ao afirmar, de modo um tanto positivista talvez, que as lendas tratam de preocupações universais, das questões mais cruciais do mundo e da vida humana. Segundo a autora, as lendas suscitam perguntas do tipo:

"A ordem do mundo é mesmo essa que nos ensinaram? Podemos esperar que a vida irá seguir seu curso como aprendemos que ela deveria? Nós 
conhecemos as forças que regulam o universo e a nossa vida, ou existem dimensões escondidas que podem desviar o fluxo causal e racional das coisas? E se há forças desconhecidas, podem elas ser identificadas, alteradas, evitadas ou exploradas em nosso benefício?” (Dégh 2001: 2)

Ceticismo, ironia, ansiedade, pavor: seja qual for a atitude que adotemos diante das lendas urbanas e sua “improvável veracidade”, ela haverá de ser resultado de um reconhecimento e ao mesmo tempo de um desconforto com algo que "não se encaixa bem” na ordem das coisas que cremos natural.

\subsection{Rumores e Faits Divers}

Vimos como as lendas urbanas, ao estarem inseridas em processos discursivos mais amplos que o simples "contar uma história”, podem assumir modalidades distintas de expressão, não sendo redutíveis a uma história básica subjacente. Duas dessas modalidades discursivas me retêm a atenção mais particularmente a partir de um exame inicial do corpus estabelecido para este trabalho: os rumores e os fait divers. A seguir, discuto cada uma delas em detalhe a partir de um levantamento teórico.

\subsubsection{Lenda ou rumor?}

Alguns folcloristas insistem em definir rumor como um gênero à parte, com características formais próprias que a destinguem da lenda. Brunvand, por exemplo, define o rumor como um "relato breve, anônimo e não-verificado de um suposto acontecimento que circula de boca em boca ou pela mídia” (Brunvand 1981: 194). Diferentemente da lenda, o rumor tende a ser não-narrativo e ter vida curta, embora possa contribuir para o crescimento e difusão de uma lenda. Klintberg, por sua vez,

enfatiza justamente o aspecto da difusão como sendo a marca principal do rumor - que muitas vezes se resume a uma simples declaração -, em oposição ao conteúdo narrativo, que caracterizaria a lenda. (Klintberg 1985: 285 apud Dégh 2001: 84).

Outros estudiosos, no entanto, postulam haver uma diferença muito pouco substancial, ou no mínimo nebulosa, entre lenda e rumor. Fine, entre eles, aponta para a chamada "estrutura de credibilidade", isto é, o fato de que ambos gêneros se 
caracterizam por uma proposição à crença. Além disso, tanto a lenda quanto o rumor podem mobilizar conteúdos tradicionais e ecoar aspectos da situação social imediata dos falantes/ participantes do processo de transmissão. (Fine 1992: 2-3). Para o autor, os dois gêneros parecem tão imbricados que com freqüência é difícil saber onde termina um e onde começa o outro. De fato, é comum a percepção de que os temas mais ou menos limitados e previsíveis dos rumores possam se expandir em lendas, à medida em que sobrevivem a sua breve realização assumindo um caráter mais narrativo e ganhando longevidade dentro de uma determinada tradição cultural.

Entretanto, a pergunta se coloca: como sabemos se uma lenda é sobrevivente de um rumor? Em outras palavras, como identificar o momento em que um rumor deixa de ser rumor e assume o "estatuto" de lenda? Essa dificuldade epistemológica se manifesta, como bem aponta Dégh (2001: 84), no trabalho de pesquisadores, jornalistas e estudantes da área, que perseguem avidamente os meandros que tais relatos assumem nos mais diversos canais de comunicação contemporâneos em busca de uma "lenda em emergência” - para no fim descobrirem que muitos deles não ultrapassam a barreira de sua própria efemeridade, ou seja, não se tornam lendas, quer porque são desbancados com a mesma velocidade com que se difundem, quer porque novos rumores thes vêm substituir, quer ainda porque não repercutem de modo mais intenso além dos limites de uma ou outra comunidade discursiva.

Evidentemente, tal condição se aplica ao meu próprio processo de coleta de material para análise. Como já sugeri na Introdução, tenho à disposição um conjunto de textos que materializa mesmo essa indefinição de gêneros. Vários são os threads do grupo de discussão na Internet que tentam cercar os rumores de todos os lados em questão de horas e poucos dias, até serem deixados de lado completamente, ou eventualmente serem retomados sob um novo enfoque tempos depois.

Mas para não nos restringirmos apenas ao âmbito dos estudos de folclore, caberia mencionar a interessante discussão proposta por Orlandi a respeito dos boatos. Segundo a autora, a formulação desses burburinhos, desses relatos surdos não comprovados, é o anúncio da chegada de um discurso, o que possibilitará a construção, em forma de texto, de um dizer a partir de um "fato". Os boatos seriam uma forma de discurso "à procura de uma memória (de um saber dizer), para produzir o efeito de estar em uma filiação, uma rede de significação constituindo uma tradição de sentidos possíveis, até mesmo necessários” (2001: 136). Assim, arriscaria dizer que é na medida 
em que deixam um rastro permanente, que encontram e se filiam a essa memória, que os boatos podem produzir um efeito de verdade que os "promova" ao estatuto de lenda dentro de uma tradição de sentidos plausíveis.

Reportando ainda essa última discussão ao que diz Dégh (2001: 131) sobre os rumores assustadores que envolvem ameaças à segurança de indivíduos e grupos como os vírus de computador, o roubo de órgãos para tráfico, os cultos satânicos, entre vários outros -, é possível dizer que quanto mais "perigosos e virulentos” forem esses rumores, ainda que em sua mínima elaboração narrativa, maiores as chances de eles se articularem aos temas poderosos que concernem "os medos do momento" e de se desenvolverem em mini-narrativas improvisadas e adaptativas, como espécies de “agregados de lendas contemporâneas”. Talvez seja esse mesmo um bom termo para definir parte do material à disposição para análise.

\subsubsection{Lenda ou fait divers?}

Lendas podem se desenvolver também a partir de material jornalístico. É comum que agências de notícias ou jornais não necessariamente sensacionalistas ${ }^{7}$ dediquem uma seção regular a histórias do cotidiano com algum conteúdo curioso, inusitado, que chame a atenção pela articulação de elementos a princípio incongruentes em sua própria estrutura. Esse tipo de notícia ecoa o que se chama em francês de fait divers - algo como "fato curioso", ou "curiosidade", em português. Segundo Roland Barthes, que discutiu o gênero em um de seus inúmeros ensaios, o fait divers não apresenta um conteúdo que seja propriamente estranho ao mundo. Acidentes, roubos, assassinatos, esquisitices e outros temas típicos do fait divers, remetem ao homem, "a sua história, a sua alienação, a seus fantasmas, a seus sonhos, a seus medos”. (1966/2003: 58). Porém, o que o torna notável é a relação que articula entre os elementos enunciados, remetendo para si próprio todo o efeito de surpresa, choque ou horror. O autor dá como exemplo o seguinte enunciado: "Empregada rapta o bebê de seus patrões”. Em função do estereótipo, faz-se crer imediatamente que se trata de um seqüestro convencional com um único objetivo: um resgate. No entanto, o que permitiu que o fato se tornasse notícia foi a quebra do estereótipo: a empregada raptou a criança por amá-la e querer tomá-la para si.

\footnotetext{
${ }^{7}$ É o caso, por exemplo, do site da Reuters na Internet, que publica uma seção diária chamada Oddly Enough.
} 
Ocorre aqui o que Barthes chama de causalidade desregulada: um evento prosaico, de causa cultural e socialmente presumível, torna-se um acontecimento importante - ou pelo menos digno de nota, newsworthy - pela reversão (muitas vezes decepcionante) do estereótipo no momento em que são reveladas as motivações reais desse evento. Tal reversão, porém, longe de enfraquecer o impacto da notícia, reforça-a em pelo menos dois aspectos: por um lado, cria um efeito segundo o qual as causas dos eventos podem estar em toda a parte - num mundo superhabitado por signos, cujo poder é infinito e onipresente -, potencialmente ligando o homem a qualquer elemento do cotidiano; mas, por outro lado, ocasiona a perda do controle dessa mesma causalidade na medida em que esta se submete a forças que lhe escapam. Nos dizeres de Barthes:

"perturbada sem entretanto desaparecer, [essa causalidade] fica de certo modo suspensa entre o racional e o desconhecido, oferecida a um espanto fundamental; distante de seu efeito (e é isto, no fait divers, a própria essência do notável), a causa aparece fatalmente penetrada por uma força estranha: o acaso; no fait divers, toda causalidade é suspeita de acaso.” (Barthes 1966/2003: 63)

Ora, estamos diante de um universo que, ao menos potencialmente, nos convida a transformar rumores em lendas, fatos curiosos e efêmeros em histórias mais duradouras. O que permite que essas histórias permaneçam seja talvez a necessidade que as sociedades contemporâneas têm de fazer sentido desse mundo povoado de signos ao mesmo tempo reconhecíveis e incertos; confortantes, na medida em que remetem a um mundo cheio de signos - ou seja, de sentido -, e insondáveis, na medida em que escapam das formas mais convencionais e estereotípicas da cultura, buscando, no percurso, tornar-se símbolos.

Cria-se, assim, uma espécie de ironia quando se pensa na lenda como uma história velha vestida de nova, uma vez que, para os que aderem a seu processo de transmissão/recepção, o que a torna material de notícia é o fato de emergir como "notícia fresquinha". Dégh chama a atenção para esse efeito, lembrando que "[O]s assinantes de jornais locais podem até gostar de ler sobre mistérios passados, mas com seu café da manhã o que querem é ser informados sobre as novas 'bombas' (new shockers)" (2001: 170-1). 
Teremos a oportunidade de aprofundar essas questões em capítulos posteriores. Por ora, gostaria de entrar um pouco mais na discussão sobre gênero, e para isso proponho uma revisão teórica em torno desse conceito na seção a seguir.

\subsection{Desconstruindo o conceito de gênero}

O que surge primeiro: uma história particular ou um gênero? $\mathrm{O}$ ovo ou a galinha? O teórico norte-americano Jerome Bruner nos lembra que estudiosos vêm tentando, desde a época de Aristóteles até os dias de hoje, decidir se os gêneros “geram” histórias particulares - levando à interpretação de seqüências de eventos de acordo com sua prescrição genérica - ou se eles são “meros pensamentos a posteriori que ocorrem para organizar as mentes acadêmicas” (1996/2001: 129).

Com efeito, é possível observar como histórias particulares tendem a ser interpretadas como se se encaixassem em gêneros preexistentes, evocando fórmulas como: “o bem vence o mal”, “o feitiço vira contra o feiticeiro”, “a curiosidade mata”, “mentira tem perna curta”, “o castigo vem a galope”, e assim por diante. Não seria possível começar a interpretar qualquer forma narrativa se não lançássemos mão de um suporte de conhecimento prévio sobre categorias preconcebidas, os chamados gêneros. Na definição do autor, os gêneros seriam "formas culturalmente especializadas de vislumbrar a condição humana e de comunicá-la” (op. cit.: op. cit.). No trabalho de interpretação do mundo, acabamos por não "resistir" à imposição de categorias genéricas aos personagens e situações que nos rodeiam na vida cotidiana, assimilandoos aos formatos que a cultura desenvolveu e consolidou.

De fato, o que faz com que os gêneros tenham um caráter social e historicamente determinado é o fato de estarem ligados a instâncias concretas de produção de linguagem. Como bem aponta Grillo, “[E]m vez de uma forma na qual se viriam alojar os conteúdos ideológicos, o gênero já é uma interpretação do real a partir de um lugar de produção de linguagem” (2004: 46). Essa interpretação do real se substancializa, por sua vez, sob a forma de regularidades, especificidades e convencionalidades que se constituem como parâmetros interpretativos inscritos num cânone, numa memória discursiva acessível aos membros da comunidade que compartilham daquele gênero. $\mathrm{E}$ o reconhecimento dessas regularidades torna possível, ainda que provisória, a 
“ancoragem interpretativa” que diferencia um gênero do outro, tanto em sua produção quanto em sua recepção.

No entanto, não se pode pensar no gênero como uma força meramente conservadora. Da mesma forma em que tende a uma estabilização, essa força é submetida a contínuos deslocamentos em virtude mesmo de sua inserção numa determinada prática sócio-histórico-culturalmente localizada (Pinheiro 2002: 286). Uma prática, bem entendido, que envolve a língua, a história e os sujeitos. Essa dupla natureza do gênero, em sua força tanto de estrutura (reguladora) quanto de acontecimento (transformador), é resumida por Gregolin nos seguintes termos:

“O gênero é, portanto, um operador da memória social que permite as retomadas e os deslocamentos de sentidos, que distribui papéis e institui lugares que podem ser ocupados por sujeitos historicamente situados. Assim, muito mais do que uma pura forma concluída, ele é um espaço móvel onde vêm-se encontrar o sujeito, a língua e a História.” (Gregolin 2005: 32)

Problematizando a questão um pouco mais, vale evocar a discussão que Derrida propõe a respeito de gênero (1992: 230-1). Para o autor, não se pode, certamente, conceber um texto sem gênero. Mas também não se pode dizer que um determinado texto pertença, propriamente, a determinado gênero. Antes, o gênero participa de um ou vários gêneros. Seguindo o raciocínio de Derrida, que usa o gênero do romance como exemplo, tomemos a designação "lenda urbana”. De uma forma ou de outra, ela pressupõe uma marca, ainda que não explicitamente rotulada, ou ainda que atribuída de forma confusa ou irônica. Essa marca, no entanto, não encerra em si uma finalidade, um acabamento completo. Ela opera em suas fronteiras simultaneamente uma inclusão e uma exclusão em relação ao gênero como categoria. Em outras palavras, a designação marca e ao mesmo tempo demarca um lugar de significação. Esse lugar de significação reúne o corpus sob uma identificação provisória (uma legenda), mas no mesmo movimento, impede-o de se fechar, de se identificar consigo mesmo. Assim, a lenda não pertence ao corpus. Ela é instituída pelo corpus ao mesmo tempo em que o sustenta. Instaura sua própria condição de possibilidade e reconhece a impossibilidade de uma taxonomia categórica. 
Podemos dizer que o gênero, dessa forma, funciona analogamente ao arquivo, assim descrito pelo próprio Derrida em um outro ensaio: “[T]odo arquivo... é ao mesmo tempo instituidor e conservador. Revolucionário e tradicional. Arquivo eco-nômico neste duplo sentido: guarda, põe em reserva, economiza, mas de modo não natural, isto é, fazendo a lei (nomos) ou fazendo respeitar a lei” (1995/2001: 17). O arquivo, enfim, não se fecha numa coleção; demanda sempre e está sempre pronto a incorporar novo material.

A partir dessa discussão preliminar, podemos concluir para nossos fins que a indeterminação e heterogeneidade dos gêneros, antes de serem fatores complicadores para a delimitação das lendas urbanas, é uma condição inescapável dos processos discursivos por meio do qual elas (e qualquer outro gênero narrativo, afinal) se constituem. De uma forma ou de outra, todos os autores discutidos acima levam em conta essa preocupação. A relativa estabilidade das formas genéricas - já descrita na definição clássica de gênero tal como se encontra em Bakhtin (1952-3/2000: 279-287): “tipos relativamente estáveis de enunciados... formas típicas de enunciado” - deve, portanto, ser enfatizada na análise na medida em que: por um lado, é preciso trabalhar com categorias a priori que permitam a própria operação da análise, isto é, a “ancoragem, ou lei interpretativa” (aqui temos um rumor, acolá provavelmente uma lenda, por exemplo); por outro lado, não se pode jamais perder de vista o "trânsito interpretativo” resultante da fluidez dessas categorias, de sua composição heterogênea por natureza, tanto no sentido de não serem formas “puras” por si sós, quanto no sentido de que estão constantemente articuladas com outras categorias afins, compartilhando o espaço discursivo em que circulam (aqui temos uma notícia de jornal contendo simultaneamente um rumor e um relato factual, por exemplo).

\section{Condições de Produção: As Lendas Urbanas na Ordem do Discurso}

Venho insistindo até aqui que as lendas urbanas estão envolvidas em processos discursivos e que sua realização não se dá por meio de textos fechados. Em outras palavras, tenho procurado identificar nosso objeto de estudo dentro de uma ordem do discurso. Nesta seção, exploro um pouco mais tal hipótese tratando das condições de produção desse discurso, especialmente o modo como ele aparece no grupo de 
discussão da Internet que irei analisar. Para isso, proponho tomar como ponto de partida a tese defendida por Michel Foucault na aula/ensaio A Ordem do Discurso (1971/1996) e investigar os mecanismos de produção e controle do discurso por ele apontadas.

Trata-se de um dispositivo de interpretação que tem a vantagem de servir como uma espécie de roteiro para a descrição das condições de produção e distribuição das lendas urbanas enquanto práticas discursivas. Não pretendo, porém, tomar tal dispositivo como um modelo fechado, pois isso fugiria ao próprio objetivo deste trabalho (e às idéias do próprio autor em que esta análise se baseia ${ }^{8}$ ). Adoto-o, antes, como um instrumento auxiliar ao entendimento daquelas práticas, focando a atenção, ainda neste momento inicial da discussão, sobre as regularidades do discurso, ou seja, aquilo que ele tem de mais propriamente estrutural.

Mas qual a tese em questão? Foucault propõe que a produção do discurso é, em toda sociedade, “controlada, selecionada, organizada e redistribuída por certo número de procedimentos que têm por função conjurar seus poderes e perigos, dominar seu acontecimento aleatório, esquivar sua pesada e temível materialidade” (op. cit.: 8-9). Identifica, assim, três conjuntos de procedimentos que funcionam como reguladores do discurso. Dentro de cada um desses conjuntos, identifico e analiso em seguida os procedimentos que têm uma relevância mais direta em relação ao nosso objeto de pesquisa.

\subsection{Procedimentos de Exclusão Externos}

Os procedimentos de exclusão externos são aqueles mecanismos que limitam o desejo e o poder que agem sobre o discurso. Discutirei aqui somente um desses procedimentos, que é a interdição ${ }^{9}$. Segundo Foucault, são três os tipos fundamentais de interdição, que se entrecruzam e que constantemente se modificam: o tabu do objeto, o ritual da circunstância, e o direito privilegiado ou exclusivo do sujeito que fala (ou escreve).

\footnotetext{
${ }^{8}$ A propósito disso, Foucault enumera algumas tarefas metodológicas a serem observadas na análise dos discursos, dentre as quais está o que chama de princípio da especificidade. Segundo esse princípio, não se deve transformar o discurso em um jogo de significações preconcebidas; "não imaginar que o mundo nos apresenta uma face legível que teríamos de decifrar apenas; ele não é cúmplice de nosso conhecimento; não há providência pré-discursiva que o disponha a nosso favor” (op. cit.: 56).

${ }^{9}$ Os outros dois procedimentos de exclusão externos são (a) os da separação e da rejeição, que tratam respectivamente da oposição entre razão e loucura e da segregação da loucura, questões que não se aplicam diretamente à nossa discussão; e (b) o da oposição verdadeiro/falso e a vontade de verdade/vontade de saber implicadas nessa oposição, que será assunto central do Capítulo 3.
} 


\subsubsection{O tabu do objeto}

Não se pode falar de qualquer assunto em uma determinada comunidade de discurso. Há os assuntos privilegiados, há os irrelevantes, e hás os interditos. No ambiente da comunidade virtual onde se situa o corpus (ver Introdução), existem mecanismos específicos que regulam o que se qualifica como “material lendário”, o que é off topic $[O T]$, o que é notícia, o que é boato, etc. Por exemplo, assuntos que comentam os acontecimentos recentes, mas que não sugerem, ainda que indiretamente, qualquer elemento contencioso (ou não imediatamente verificável) tendem a ser excluídos do debate, ou simplesmente ignorados.

De um modo geral, no entanto, o conteúdo veiculado pelo site www.snopes.com (Urban Legends Reference Pages) inclui material que vai além do que se poderia definir como lenda urbana em sentido estrito. Diz o texto da seção FAQ (Frequently Asked Questions) do site, em resposta à pergunta: “Tudo neste site é sobre lendas urbanas?”:

“Em um sentido folclórico estrito, não. Lendas urbanas são um tipo específico de folclore, e muitos dos itens discutidos neste site não se encaixam na definição folclórica de 'lenda urbana'. Nós seguimos o uso mais amplo e popular (ainda que impreciso) de 'lenda urbana' como um termo que abrange não apenas as lendas urbanas mas também falácias comuns, informações falsas, crendices populares, fatos jornalísticos curiosos, rumores, fofocas sobre celebridades, e afins." 10

Dentro da própria lista de discussão, não faltam também auto-referências sobre o que se faz ali, do que se fala e do que não se fala. Isso é bem ilustrado pelo seguinte trecho de uma mensagem postada em 20 de agosto de 2005 por Mr. Calvin, um membro mais antigo da lista, em resposta a um novato que se diz "desapontado" com o site por este não estar cumprindo seu papel de “desbancar” lendas, e sim perpetuando-as:

"Sinto muito por você estar desapontado. Esta lista não está aqui para meramente desbancar rumores. Nós estamos aqui para discutir folclore

\footnotetext{
${ }^{10}$ Os sites de referência sobre lendas urbanas citados diretamente neste trabalho estão incluídos entre as Referências bibliográficas - ver seção a) da Bibliografia.
} 
urbano, que pode vir na forma de rumores e farsas, lendas, piadas, receitas e fábulas modernas sentimentalistas as quais chamamos de glurge. Ela inclui movimentos sociais do tipo mensagens de boca-a-boca (como petições do momento) e muitas outras coisas relacionadas. Há membros aqui que se deleitam em desbancá-las, claro, porque reportar os fatos corretamente é importante para eles. Mas esse é um passo secundário em relação ao nosso objetivo principal: que é saber sobre esses fatos. Colecioná-los, em suas variantes, e em sua freqüência." ${ }^{11}$ (in: Virus (yeah, right), 20/8/2005)

Considerando-se, conforme já apontei na primeira seção deste capítulo, a dificuldade de se definir de um modo preciso o que seja uma lenda urbana (ou contemporânea), ainda que num sentido "estritamente folclórico", não haveríamos de estranhar a proposição do site de incluir tal variedade de gêneros. Um exame superficial do nosso corpus já comprovaria essa tendência. Seria o caso, então, de perguntar o que dentro dessa comunidade pode ser visto como tabu do objeto, isto é, que tipo de práticas se vêem ameaçadas e potencialmente excluídas dentro desse regime discursivo?

Uma dessas práticas se pode apontar desde já: quando a discussão se encaminha para uma troca de comentários políticos, julgados como "estritamente subjetivos”, há uma tendência por parte da moderadora da lista de intervir, bem como de outros membros da lista (em geral os mais assíduos e veteranos) de expressarem suas objeções ou restrições. Vejamos um exemplo disso que estamos tratando. Entre os dias 3 e 6 agosto de 2005, depois de uma seqüência relativamente tranqüila de troca de posts dentro da lista - isto é, num fluxo não muito acima da média -, uma enxurrada de mensagens começa a ser enviada, muitas das quais motivadas por um suposto "teste de história” de múltipla escolha em circulação pela Internet ${ }^{12}$. O teste é reproduzido por Andrea Tringo, que, mesmo temendo "perpetuar a loucura", demanda saber dos colegas membros da lista se já haviam tomado conhecimento do assunto e o que teriam a comentar a respeito. Cada questão do teste perguntava sobre a autoria de diversos

\footnotetext{
${ }^{11}$ Neste capítulo, mais teórico, opto por traduzir também os trechos de mensagens citados diretamente do corpus.

${ }^{12} \mathrm{O}$ thread em questão se relaciona diretamente com uma outra seqüência longa de mensagens correndo simultaneamente naquele período (sob a rubrica Chain Email about Stupid American), que será analisada no Capítulo 6, seção 1.
} 
crimes históricos ocorridos ao redor do mundo e supunha como resposta correta sempre a da última alternativa, a mesma em todas as questões: "Muslim male extremists between the ages of 17 and 40”. Ora, configurava-se aí, uma tendência indisfarçadamente discriminatória, anti-muçulmana. O suposto autor do teste era citado na mensagem, comentando, ao final da série de 13 perguntas, sobre como os fatos “por si sós” desqualificavam a acusação de racial profiling, isto é, a prática de discriminação explícita contra determinado grupo de pessoas com determinadas características étnicas. Ele fazia isso para protestar contra a decisão dos aeroportos norte-americanos de não mais praticar o profiling em seus procedimentos de segurança, passando a abordar passageiros por meio de uma amostragem aleatória, supostamente menos discriminatória.

Uma série de comentários inflamados se segue e logo o assunto principal passa a ser a morte do brasileiro Jean Charles de Menezes pela polícia britânica por tê-lo confundido com um terrorista. Algumas tantas mensagens depois, Karen Hoyt resolve interferir em favor de uma discussão mais fundamentada em referências factuais e menos em opiniões eventualmente ofensivas. Pergunta ela:

“Então, qual é a razão de continuar uma discussão que está fadada a não resolver nada, não lançar nenhuma luz nova sobre os assuntos em questão, e que está rapidamente se deteriorando em uma luta de gritos virtuais numa lista com centenas de assinantes? Não que opiniões estejam banidas, ou não sejam bem-vindas. Só me parece uma perda de tempo simplesmente ficar repetindo sempre as mesmas [opiniões] de modo cada vez mais cáustico, e sem nenhuma informação nova, 'na frente' de centenas de leitores desconhecidos.” (in: This is a discussion list (was:

Comment on the British incident), 4/8/2005)

Ao que R. (Mr.) Cuplin, um dos debatedores mais ativos até então e quem havia motivado o post de Karen mais diretamente, responde:

“Eu devo a todos um pedido de desculpas por me desviar do trilho. Karen Hoyt me lembrou sobre o propósito deste grupo. De alguma maneira, eu tinha conseguido me esquecer de que este é um fórum para 
desbancar lendas e não uma página de editorial. Me desculpe, pessoal.

Eu vou ver se consigo me ater a escarafunchar os fatos." (in: This is a discussion group, 4/8/2005)

Karen parece estar preocupada não com o fato de a lista estar discutindo um assunto tabu por si mesmo, assunto que pode até não ter um elo direto com as lendas urbanas (e portanto off-topic), mas sim por o debate estar se tornando perigosamente fora de controle. Assim, a resposta de Cuplin, com toda sua aparente sinceridade, poderia muito bem ser lida com um toque de ironia!

Uma outra prática que costuma gerar formas semelhantes de reação, trazendo à tona um outro tabu do objeto, é a do debate de fundo religioso. Muitas vezes originado de discussões sobre determinada questão do momento, o debate passa a assumir formas de pregação e militância religiosas que logo vem a ser refreadas. Como exemplos desse tipo de debate, poderia citar, além desse surgido na esteira do "teste de história" antimuçulmano, que acabo de discutir, aquele que foi motivado pelas mensagens que se seguiram à passagem do furacão Katrina pela costa leste dos Estados Unidos em setembro de 2005, as quais serão analisadas na segunda parte do Capítulo 3.

O que podemos concluir a partir dessa exposição é que, no que se refere aos chamados tabus do objeto, estamos diante de uma contradição estrutural, inerente à ordem do discurso. Se de um lado existe a abertura para a discussão de textos afins à lenda urbana, o que abre o espectro do tipo de conteúdo que se aceita circular e comentar na lista - incluindo aí os diferentes pontos de vista (como lembra a mensagem de Mr. Calvin, os que "devem” desbancar as lendas vêem nisso a razão de existência da comunidade) -, há por outro lado um mecanismo de controle que tende a cercear a "livre” circulação de opiniões políticas e/ou religiosas. Quer dizer, quando o debate parece "esquentar", apela-se para um suposto "objetivo primário" da lista - o de discutir lendas - buscando-se assim conjurar o mal que o discurso inflamado e dito “subjetivo" pode infligir. É como se se permitisse aventar de tudo nesse fórum, os rumores mais ou menos absurdos ou improváveis - pode-se acreditar ou desacreditar neles, mas não se pode, por exemplo, entrar em guerras verbais que ameacem marcar a comunidade como partidária de uma outra ideologia radical.

Mas como escapar da ideologia e da discussão inflamada quando lendas deixam de ser simplesmente historietas curiosas e divertidas dentro de uma compilação de 
textos e passam a circular - como, de resto, qualquer outra forma de discurso - dentro de um regime de práticas dotado de regras e investido de desejo (de poder, de verdade, de afirmação de identidades)? Como acrescentaria ainda Joe Yuska, um outro membro que se declara um veterano, participando da lista há pelo menos oito anos: "São nossas opiniões e reações passionais (gut feelings) sobre essas histórias que nos trazem a esse lugar, afinal".

Não creio, no entanto, que essa contradição, que chamei de estrutural, represente um verdadeiro paradoxo. Quando pensamos nos termos da proposição de Foucault segundo a qual a proliferação dos discursos, antes de ser uma celebração festiva da circulação infinita dos discursos, funciona como elemento de restrição desses discursos, entendemos porque multiplicam-se os textos e rarefazem-se os discursos.

\subsubsection{O ritual da circunstância}

Os discursos normalmente requerem uma circunstância determinada para que se produzam. O que equivale a dizer: não podem ser produzidos em qualquer circunstância. Os estudiosos de folclore tradicionalmente buscavam nas fontes orais o material para a análise de lendas, contemporâneas ou não. Numa visão mais tradicional, acreditava-se que era preciso recorrer a uma fonte original e autêntica a partir da qual se desdobrariam as variáveis, os rituais de transmissão e re-transmissão.

Com o advento da Internet como um meio horizontalmente democrático de veiculação de material lendário, passou-se a revalorizar a modalidade escrita como meio principal de uma prática. O que merece nossa atenção, porém, não é simplesmente o fato de lendas aparecerem na fala ou na escrita, e sim o que poderíamos chamar de recontextualização do ambiente de transmissão. Quer dizer, com a Internet é possível criar uma circunstância permanente de troca desse tipo de material. Dispensando a necessidade de um ritual que reúna pessoas em torno de uma roda para se contar histórias, ou em torno de uma mesa de bar, por exemplo, a comunidade de internautas vê aberta a possibilidade de trocar mensagens sempre que quiser, de encaminhar e reencaminhar posts recebidos sempre que julgar relevante. Conforme sugere Fernback, as pessoas muitas vezes decidem encaminhar mensagens, sobre cuja autenticidade ou veracidade não podem atestar, somente para “desencargo de consciência”. Escreve a autora: “A lenda pode não ser crível o suficiente para se transmitir pessoalmente, mas 
a imediatez e efemeridade da comunicação mediada por computadores permite ao usuário distribuir a lenda e participar no ritual de contá-la sem muito esforço.” (2003: 42)

De fato, quando se trocam lendas pela Internet, não é necessário que se responda ou reaja imediatamente, como em uma interação face-a-face. Quando as pessoas simplesmente encaminham as mensagens, não esperam aprovação ou rejeição imediatas. Quando fazem parte de uma comunidade virtual, podem também ficar apenas lendo (lurking) sem envolvimento direto. Podem ainda “esconder-se” sob apelidos. Enfim, não precisam estar reunidas com um propósito específico. Mas, claro, talvez não sejam tão comuns os rituais orais de transmissão com esse mesmo propósito. Conforme já aludi na Introdução e em discussões anteriores neste capítulo, as lendas urbanas aparecem em meio a outros processos discursivos, em meio a conversas informais, em festas, viagens, etc. O que quero mostrar é que na Internet ocorre uma espécie de nivelamento de práticas, uma democratização do narrar, reunindo eventualmente as pessoas, sim, mas em torno de textos que se podem deletar, ignorar, ou perpetuar comentar, enfim -, interferindo-se em seu destino de maneira mais livre e desritualizada. Isso nos conduz diretamente à discussão seguinte, sobre quem tem o direito de dizer/escrever as lendas.

\subsubsection{O direito de quem fala (escreve)}

Seria então o caso de pensar que todos os que participam do processo discursivo estão em pé de igualdade e gozam dos mesmos direitos? No fórum específico que é a comunidade virtual que se está estudando, vê-se, obviamente, que certas interdições se impõem quanto ao direito de quem escreve. Entrarei em pormenores a respeito do funcionamento da lista de discussão enquanto comunidade logo a seguir, quando tratar das questões do autor e das “sociedades do discurso". Por ora, descrevo brevemente os diferentes papéis que se estabelecem no regime de troca de mensagens dentro da lista.

Membros veteranos: Funcionam como uma espécie de guardiões do discurso. São normalmente os mais participativos, tanto no que se refere a propor material para discussão quanto para discutir material já proposto. Referem-se uns aos outros como se já conhecessem o estilo e as idiossincrasias de cada um, os temas preferidos, os temas 
que mais irritam. São também os que freqüentemente, num gesto auto-reflexivo, se voltam para o discurso da comunidade. Discutem os limites do que pode e do que não pode ser dito, ponderam sobre o que lhes parece estar saindo de controle. E, principalmente, garantem que uma das funções principais da comunidade, a de “desbancar” as lendas, seja devidamente preservada, na medida em que se armam de argumentos cada vez mais incisivos para comprovar a falsidade de determinada lenda ou rumor. Em suma, os membros veteranos são aqueles que mais tendem a ativar a memória da prática (inter)discursiva, reatualizando-a, mas deslocando-a sempre. Formulam e reformulam os enunciados (verdadeiros), instaurando a repetibilidade daquilo que é passado mas que torna também aberto o futuro das práticas discursivas ${ }^{13}$.

Moderadora: Conforme já apontado, trata-se da co-fundadadora e mantenedora do site. Espera-se dela uma pronta intervenção em casos mais contenciosos, uma vez que a ela se atribui o poder, pelas regras da comunidade, de impor limites à proliferação ao mesmo tempo “inútil” e "perigosa” de um discurso repetido - um discurso que todos já ouviram antes e que pertence talvez melhor a alguma outra lista (como costuma sugerir).

Membros novatos: São os que normalmente trazem questões, buscam elucidar dúvidas. Muitas vezes, por não estarem a par da “extensão histórica” de determinados enunciados na memória da lista, fazem aparecer como novo o que já é há tempos sabido. Entre os veteranos e eles, cria-se uma dinâmica interessante que revela uma espécie de “desnivelamento” dos saberes. Por um lado, instaura-se o didatismo de quem “já sabe”, explicando e corrigindo o discurso falso, a crença infundada; por outro, contribui-se para manter a eletricidade das trocas discursivas, o frisson da surpresa - a fulguração efêmera com que as histórias/mensagens se lançam sucessivamente.

Lurkers: Há finalmente esses membros anônimos que participam do processo à distância, limitando-se a ler as mensagens e, muito ocasionalmente, inserir seus comentários e contribuições. Seriam o equivalente daquela platéia que acompanha

\footnotetext{
${ }^{13}$ Evocando as palavras de Pêcheux, o que temos aqui é um "espaço aberto de retomadas, formando trajetos em redes de textos (com pontos de acumulação instáveis, organizando redes de memória provisoriamente regularizadas, expostas ao choque dos acontecimentos)" (Relatório de 1983 apud Maldidier 1989/2003: 92).
} 
silenciosa o desenrolar de um espetáculo, mas da qual não se pode precisar o número, o volume, nem aferir a adesão. Sabe-se que estão lá por algum motivo, mas não se pode antecipar como seus gestos de interpretação irão afetar a prática discursiva em seus desdobramentos.

\subsection{Procedimentos de Exclusão Internos}

Os procedimentos de exclusão internos são aqueles que operam do interior do discurso sobre ele mesmo - sobre sua aparição aleatória - agindo na dimensão do acaso e do acontecimento. Discuto dois deles aqui: o comentário e o autor.

\subsubsection{O comentário}

Há uma riqueza de práticas de comentário, constituintes do próprio processo discursivo de trocas de mensagens num grupo de discussão. Mas podemos nos referir ao comentário sob um ponto de vista bem particular: como uma função. Foucault propõe uma visão dialética do comentário. Por um lado, há o seu aspecto produtivo, que possibilita a construção infinita de novos discursos: "o fato de o texto primeiro pairar acima, sua permanência, seu estatuto de discurso sempre reatualizável, o sentido múltiplo ou oculto de que passa por ser detentor, a reticência e a riqueza essenciais que lhe atribuímos”; por outro lado, seu aspecto coercitivo: “o de dizer enfim o que estava articulado silenciosamente no texto primeiro.” (1971/1996: 25). Assim, em um paradoxo incontornável, o comentário aparenta dizer pela primeira vez aquilo que já havia sido dito, e repetir continuamente aquilo que nunca havia sido dito.

O que acredito ser o aspecto mais revelador dessa discussão é a idéia de que o comentário possa ser um fator de cerceamento do discurso, agindo no sentido de conjurar o acaso e impedir que novos saberes ameacem os saberes já estabelecidos. Por mais que uma lenda ou rumor reapareça nos meios de comunicação como uma novidade, de conteúdo inusitado ou inédito (ver a discussão sobre os faits divers na seção 1.2 acima, por exemplo), haverá sempre um movimento de “cercar”, rarefazer

esse discurso. O que pode se dar de diversas formas: com explicações e referências a fatos cientificamente comprovados, a conhecimentos que os membros julgam que outros membros têm, a avaliações de especialistas, a argumentos e contra-argumentos - 
enfim, toda uma gama de comentários que buscam absorver o acontecimento dentro de uma estrutura já reconhecida, onde os sentidos podem ser (temporariamente) assentados.

Em outras palavras, é justamente porque há sistema que o acontecimento pode

aflorar. É justamente porque existe um arsenal de conhecimentos disponíveis à mão quer sejam eles de cunho tradicional, técnico-científico, ou meramente "intuitivos”prontos para serem mobilizados no fio do discurso (isto é, recuperados de uma memória) que os acontecimentos podem proliferar, que as novas versões das histórias podem se apresentar, enfim, que os comentários podem se acumular.

A ordem do discurso, é claro, jamais permanece a mesma a cada movimento dessa dinâmica - afinal, os discursos se multiplicam. Mas ela não deixa de ser a condição primeira, enquanto estrutura, para que todos os enunciados/comentários que nela se produzem estejam, como diria Foucault, no verdadeiro - isto é, que reclamem algum efeito de sentido, alguma verdade verificável, algum ponto de vista concebível em torno de um dado do real.

\subsubsection{O autor}

Questões como “quem originou o discurso”, quem é seu autor, são particularmente problemáticas no que concerne as lendas urbanas. Em um primeiro momento, poderíamos dizer que os autores de uma lenda são todos aqueles que tomam para si a tarefa de narrá-las ou passá-las para frente, eventualmente (diríamos, potencialmente) alterando seus enredos. E se essas histórias se apresentam sob a guisa de "fatos reais", elas quase nunca acontecem conosco, e sim com "um amigo de um amigo”, alguém que mal conhecemos.

Mas, ao mesmo tempo em que são apócrifas - e sua continuidade depende dessa condição, em certa medida -, tais histórias também clamam por alguma legitimação, que pode ser maior ou menor dependendo dos "elos da cadeia” que as perpetua - quer sejam estes os membros da comunidade mais ou menos assíduos, os próprios mediadores, ou propriamente as publicações que servem de fonte para as mensagens.

Certamente, quando se pensa no autor como um elemento empírico, alguém que cria um discurso individual e original, dificilmente se aplica o conceito. O que Foucault propõe, efetivamente, é pensar o autor (do mesmo modo que o comentário) como uma 
função, um "princípio de agrupamento do discurso, como unidade e origem de suas significações, como foco de sua coerência.” (1971/1996: 26). Um princípio de coerência, diríamos, que impõe alguma forma de assinatura a um discurso, independentemente de se ter subscrito o nome de um ou outro autor empírico.

Enquanto princípio de coerência, a autoria nas lendas urbanas é resultado não de um processo de escrita assinada por um autor determinado - assinatura essa que, segundo aponta Gregolin, impediria o reconhecimento de determinado discurso meramente como um discurso "cotidiano, indiferente, flutuante e passageiro, imediatamente consumível" (2004: 103) - mas sim de um trabalho de elaboração conjunta e em permanente escritura, cuja eventual assinatura surge apenas como um horizonte projetado, um gesto potencial.

Quer dizer, se alguém decide, na cadeia de interação verbal em torno de uma lenda, "selar" a questão, imprimir sua assinatura - por exemplo, decretando de uma vez por toda a falsidade de tal ou tal história - o fará somente como o resultado de uma prática de poder, de um gesto que dramatiza a busca de um significado transcendente e final para uma determinada prática de discurso. A prática, essa, pode continuar a se desenrolar como a de um discurso cotidiano, indiferente, flutuante e passageiro, ainda que sofra as pressões que qualquer poder/saber sofre para "estruturar uma memória", cristalizar-se - estabelecer-se, enfim, como verdade incontestável.

\subsection{Procedimentos de Seleção dos Indivíduos}

Finalmente, há aqueles procedimentos que, segundo Foucault, determinam as condições de funcionamento do discurso como um todo. Segue uma discussão de três deles: as "sociedades do discurso", os rituais, e a apropriação social dos discursos.

\subsubsection{As "sociedades do discurso"}

O conceito não se aplica aqui no seu sentido tradicional, de sociedade restrita e fechada. De qualquer maneira, a lista de discussão se constitui como aquilo que podemos chamar de comunidade virtual, com suas regras e mecanismos próprios.

Quando se trata de constituir uma comunidade virtual, há algumas questões que se devem levar em conta. Uma comunidade não se consolida pelo simples fato de reunir 
pessoas em torno de uma atividade, interesse ou gosto comuns. Segundo Fernback, sem um investimento pessoal, sem intimidade e sem compromisso, muitas comunidades virtuais tornam-se meros agregados de pessoas com interesses afins (1999 apud Szczepanska 2001: 6). Ora, essa espécie de vínculo efetivo que se deveria buscar criar numa “comunidade ideal” aparece na nossa lista de discussão de algumas maneiras. Podemos pensar, por exemplo, na linguagem afetiva usada por membros veteranos para se referirem uns aos outros, nas referências constantes a experiências anteriores envolvendo esses membros, na busca de unidade e respeito a regras éticas implícitas e, claro, na intervenção firme da moderadora da lista.

Mas um mecanismo em particular chama a atenção justamente por seu caráter ritualizado e tradicional. Trata-se da enquete que ocorre no final de cada ano, geralmente proposta por um membro veterano da lista (que não a moderadora), para saber quem somos nós. Nela, os assinantes da lista são convidados a responder uma pequena série de perguntas sobre o que fazem, onde vivem, por que se inscreveram na lista, etc.

No ano de 2005, especificamente no dia 6 de dezembro, o ritual foi proposto por Richard Roiz, um dos participantes mais antigos e regulares, sob a rubrica "Usual End of Year WhoAmi Thread”. Tomando a iniciativa de já se apresentar, Roiz sugere os seguintes itens:

- WHOAMI (quem sou eu)

- $\quad$ WHDR I DO (o que faço)

- WHERAMI (onde estou)

- WHEN/WHY I am on this list (quando/por que estou nesta lista)

- LIKES/DISLIKES (do que gosto/não gosto)

- FAVORITE WEEVIL (“praga de plantação” preferida)

- WHY I ADMIRE ROIZ (por que eu admiro Roiz)

- WHAT I WANT ON MY TOMBSTONE (o que quero escrito na minha lápide)

O tom descontraído e bem-humorado fica evidente não só pela linguagem como pelo tipo de pergunta. Por exemplo, a que indaga sobre a praga de plantação preferida (da classe dos besouros) "gera protestos" e causa espanto para alguns respondentes, que, obviamente, atendem à solicitação se quiserem. Num universo de pouco mais de 50 
respostas, é possível observar uma variedade considerável de perfis. Vejamos alguns dados gerais:

- A porcentagem de mulheres aproxima-se dos $70 \%$.

- Dos que declaram a idade, a faixa vai dos 23 aos 65 anos (boa parte dos quais acima dos 50).

- Quanto às profissões, encontram-se: advogado, engenheiro, donas de casa, professores, estudantes, garçonete, bibliotecária, assistentes sociais, artistas amadores, voluntários e oficiais militares e da aeronáutica, além de vários aposentados e alguns desempregados.

- Há uma predominância de americanos, embora aproximadamente $20 \%$ são estrangeiros e/ou moram em outros países, dentre os quais se destaca o Canadá.

- Há também imigrantes latinos e pessoas que têm contato direto com a cultura mexicana e da América Central.

- Alguns se declaram novatos na lista, outros tantos se definem como lurkers e mais outros especificam o período em que freqüentam a lista, alguns há mais de 10 anos.

- Entre as coisas de que as pessoas gostam, são comuns referências a elementos de pop culture (filmes, programas de TV, literatura de ficção científica, histórias em quadrinhos).

- Um bom número de respondentes inclui entre as motivações por estarem na lista o desejo de desbancar as falsas histórias e descobrir a "verdade” sobre elas.

Numa comunidade tão diversa quanto essa, a imagem que se tem do outro, de seu universo de referências, de seu conhecimento específico, só pode ser uma projeção aproximativa. Como bem aponta Bauman, "em uma sociedade marcada pela heterogeneidade e pelo advento da comunicação eletrônica como a em que vivemos, o entendimento 'natural' que pressupõe a identidade e coesão entre os membros de uma comunidade sofre um golpe fatal." (2003: 19) De certa maneira ecoando a discussão de Foucault sobre a ordem do discurso, o sociólogo nos lembra que em uma comunidade "toda homogeneidade deve ser 'pinçada' de uma massa confusa e variada por via de seleção, separação e exclusão" (op. cit.: op. cit.), de onde se conclui que a unidade que sustenta uma comunidade - no caso, virtual - só pode ser construída artificialmente, por meio de um acordo tácito entre os seus membros. 
Embora um interesse comum os una em um primeiro momento, a comunidade só se mantém - e ela existe desde 1995 - como um exercício de construção de identidades e de saberes, que busca combustível novo a partir de resíduos de discursos já ditos, conhecimentos já inscritos numa memória. Trata-se da elaboração conjunta, pela comunidade como um todo, de um arquivo que não se assenta nunca, tanto no sentido mais “material” do termo - não há, por parte de seus criadores, e provavelmente de nenhum membro da lista, um arquivo que abrigue todas as mensagens enviadas até hoje! - quanto no sentido de um acúmulo de discursos que edifica aquela memória. Os significados resistem à “documentação”, por mais que se creia tê-los “arquivados”. Como afirma Sahlins, “o significado de qualquer forma cultural específica consiste em seus usos particulares na comunidade como um todo. Mas este significado é realizado in presentia, apenas como eventos do discurso ou da ação. O evento é a forma empírica do sistema” (1985/1990: 190). Podemos dizer, portanto, que não há lendas como documentos acabados. O que há são acontecimentos enunciativos perturbando a ordem do discurso, o sistema de que são, conforme nos lembra Sahlins, a forma empírica, ou ainda, como poderia dizer Foucault, monumentos.

\subsubsection{Os rituais}

O que Foucault chama de rituais sobrepõe-se, de alguma maneira, às categorias que já apresentei nas seções anteriores. Segundo o autor, o ritual define “a qualificação que devem possuir os indivíduos que falam (e que, no jogo de um diálogo, da interrogação, da recitação, devem ocupar determinada posição e formular determinado tipo de enunciados)"; ele define também "os gestos, os comportamentos, as circunstâncias, e todo o conjunto de signos que devem acompanhar o discurso" (1971/1996: 39). Assim, nesta seção trato apenas de descrever alguns outros rituais (signos) mais específicos da lista de discussão, ainda não mencionados.

Bottom-posting: Toda vez que um participante da lista deseja comentar ou se referir diretamente a uma mensagem prévia dentro de um mesmo thread, deve fazê-lo citando essa mensagem antes do seu texto (e não depois, o que configuraria top-posting). Quando deixa de fazê-lo, costuma ser repreendido. Esse gesto, ainda que não seja consenso entre os membros, é recomendado pelos veteranos e a moderadora da lista 
com o argumento de que facilita a compreensão dos leitores sobre que conteúdos específicos estão sendo comentados. O texto “primeiro” deixa logo sua marca na cadeia seqüencial do discurso. E cria-se, com isso, um ambiente favorável para a intertextualidade, isto é, a retomada explícita do texto do outro dentro da seqüência. Como já dito a respeito do comentário, o efeito aqui é o de uma teia que se vai tecendo ao redor de um enunciado, construindo acontecimentos que vêm ativar a memória discursiva, ao mesmo tempo em que a desloca para novos sentidos.

Referência a links externos: Outro recurso tornado possível pelo funcionamento do discurso no meio eletrônico é a múltipla referencialidade a textos “externos”, situados em outras páginas. Os links remetem a textos de jornais, revistas, editoriais e outras páginas da Internet onde aparecerem as lendas. Tal recurso evidencia ainda mais a natureza dialógica (interdiscursiva) da comunicação virtual, tornando facilmente consultáveis as fontes textuais que “competem” para a construção da lenda como processo discursivo.

Glurges e off-topics: Termo cunhado por Pat Chapin, contribuidora regular da lista, refere-se ao tipo de história que costuma evocar sentimentos inspiradores e edificantes, de tom freqüentemente espiritualista. Tornou-se uma designação popular entre os membros da lista, que o empregam como um sinal de alerta sempre quando enviam mensagens desse tipo, normalmente em forma de correntes. Sinal de alerta porque o termo assume quase sempre um sentido pejorativo, uma vez que, conforme a definição que a enciclopédia eletrônica Wikipedia (já) traz, “enquanto seu propósito é de alegrar o leitor, o aspecto edificante é tão exacerbado que é mais provável que provoque náusea do que propriamente inspiração”. Dessa forma, se não é um tabu completamente interdito, o glurge se anuncia como material passível de descarte e rejeição pela comunidade logo de antemão. Outro sinal de alerta, comum a tantas outras comunidades, é a rubrica off-topic [OT], que assinala o material tratado como sendo supostamente fora do objetivo principal da discussão - embora esteja sempre a ele ligado de alguma forma, como freqüentemente se comprova. Seria o caso de se questionar o que, afinal de contas, é off-topic numa rede tão heterogênea de práticas discursivas como essa. 


\subsubsection{A apropriação social dos discursos}

Trata-se do último dos procedimentos de seleção discutidos por Foucault. O que o autor tem em mente quando fala de “apropriação social dos discursos” é basicamente a educação enquanto instituição. Embora não seja objetivo específico deste trabalho abordar uma possível aplicação do estudo de lendas urbanas ao ensino, creio ser possível pensar, nessa conexão, como a mídia contemporânea, enquanto sistema de distribuição de saberes, se apropria do discurso das lendas nos mais diversos formatos (sites da Internet, filmes, programas de TV, etc.) e como essas referências fazem parte do repertório cultural de jovens educandos.

Com efeito, aquilo que Foucault diz a respeito da educação como sistema parece valer igualmente para a mídia: "uma maneira política de manter ou de modificar a apropriação dos discursos, com os saberes e os poderes que eles trazem consigo" (1971/1996: 44). O que a popularização da idéia de lendas urbanas acabou trazendo ao longo das últimas décadas foi um conjunto de saberes (um capital cultural) um tanto difuso, é verdade, identificado e reconhecido de maneiras distintas - e em graus variados, conforme se considere a prevalência desse tipo de história na cultura popular norte-americana comparada à cultura popular brasileira, por exemplo -, e referenciado a diferentes produtos culturais. Isto é, pode-se ter ouvido falar de uma narrativa desse tipo durante um filme, em uma notícia de jornal, um site da Internet, um livro de literatura de ficção, ou uma história em quadrinhos, para citar apenas algumas.

De qualquer forma, levar em conta esse capital cultural pode se constituir, acredito, na plataforma de um trabalho interessante de discussão de questões relacionadas não somente com o poder da mídia em si, mas também questões ligadas à representação do “outro”, do “elemento estranho” e, mais amplamente, à diferença cultural e suas implicações.

É importante considerar a ressalva que o próprio Foucault faz quanto a uma certa arbitrariedade implicada a separação, em categorias distintas, dos procedimentos aqui discutidos. Pondera o autor: “[esses procedimentos] se ligam uns aos outros $e$ constituem espécies de grandes edifícios que garantem a distribuição dos sujeitos que falam nos diferentes tipos de discurso e a apropriação dos discursos por certas categorias de sujeitos". Trata-se, como conclui, dos "grandes procedimentos de 
sujeição do discurso" (1971/1996: 44). O reconhecimento dessa ressalva é importante para colocar em perspectiva a opção de examinar as condições de produção do discurso das lendas urbanas por meio daquelas categorias neste momento inicial do trabalho.

Ressalto ainda, para concluir este capítulo, que algumas das discussões apontadas aqui - como as relacionadas ao comentário e os diversos rituais, por exemplo - serão melhor desenvolvidas em momentos posteriores, quando aplicadas às análises de material do corpus. Por ora, fica lançada a base de um edifício que se pretende erigir ao longo do trabalho. O próximo estágio dessa arquitetura proponho desenvolver no capítulo seguinte, que tratará da tensão entre estrutura e acontecimento sob o ponto de vista de teorias da narrativa e do discurso, explorando no percurso as fronteiras movediças entre história, ficção e realidade. 


\section{CAPÍTULO 2: Narrativas entre a Estrutura e o Acontecimento}

"[W] hat cannot be explained is in principle capable of being understood; and ..., finally, this understanding is nothing other than its representation in the form of a narrative."

- Hayden White, The Content of the Form, 1987

"[T]o eliminate the unforeseen or expel it from calculation as an illegitimate accident and an obstacle to rationality is to interdict the possibility of a living and 'mythical' practice of the city. It is to leave its inhabitants only the scraps of a programming produced by the power of the other and altered by the event." - Michel de Certeau, The Practice of Everyday Life, 1980

\section{Lendas Urbanas como Narrativa}

Ao apresentar o tema deste trabalho na Introdução, parti do pressuposto de que as lendas urbanas são narrativas do cotidiano que dão testemunho à permanência do impulso, nas sociedades contemprâneas, de propor sempre novas (velhas) narrativas, isto é, de engendrar as experiências do cotidiano em seqüências narrativas mais ou menos padronizadas. A arte da narrativa, assim, permanece viva.

Em seguida, na primeira parte do capítulo anterior, vimos como as lendas urbanas podem estar situadas na interseç̧ão entre os rumores e os faits divers. Quando as lendas se apresentam desprovidas de um enredo desenvolvido - ainda que minimamente - na forma de relatos, elas se aproximariam mais daquele primeiro gênero. Mas quando se apresentam dentro de um paradigma em que as ações se desdobram em uma seqüência narrativa identificável, as lendas se aproximariam do segundo gênero.

Neste capítulo, proponho, num primeiro momento, refletir sobre que maneira as lendas urbanas poderiam ser consideradas propriamente como narrativas. Quer dizer, caberia investigar o que nos permitiria enquadrá-las dentro dessa categoria aparentemente tão genérica, mas ao mesmo tempo dotada de características bastante específicas, conforme o ponto de vista teórico que se adote. Para tanto, tomo como ponto de partida algumas reflexões teóricas propostas por autores de diferentes áreas notadamente da história, psicologia, antropologia e filosofia - com o objetivo de buscar aí elementos que contribuam mais diretamente para essa investigação. Finalmente, proponho olhar para as lendas como instâncias híbridas situadas entre as dimensões da 
estrutura e do acontecimento, questão esta já sugerida de passagem em nossa discussão sobre o gênero.

\subsection{Narrativa e História}

Entremos nesta discussão pela via de acesso que as reflexões sobre a escrita da história nos oferecem. De acordo com um senso comum mais ou menos estabelecido, narrativa e historiografia se apresentam como formas muito distintas, quase opostas, de

elaborar dados da realidade. À primeira normalmente se associa o elemento da criação ficcional, que constrói, sob a forma de um enredo, um determinado conteúdo da experiência. Da segunda, espera-se um relato factual e objetivo da realidade tal qual ela se passou.

Uma reflexão mais aprofundada, porém, irá revelar como tal dicotomia entre o discurso histórico e o discurso narrativo é também ela uma construção, havendo, de fato, entre as duas modalidades uma intersecção. Poder-se-ia mesmo dizer que são variantes de uma forma mais geral de elaborar os acontecimentos de uma cultura. Esta é uma visão que recusa a idéia de objetividade absoluta dos fatos, os quais seriam meramente “reportados” por um historiador. É uma visão que recusa também o elemento puramente "ficcional" dos relatos narrativos, identificando aí também elementos construídos a partir do próprio conhecimento histórico, ou de um arcabouço culturalmente pré-constituído de enredos possíveis.

Segundo o historiador Hayden White (1978/1994), um dos teóricos expoentes dessa concepção de história, é possível conferir sentido a um conjunto de acontecimentos de várias formas distintas. Há o que se chama explicação científica, pela qual os eventos, tomados como “efeitos de forças mecânicas”, são subordinados às leis causais que teriam regido seu engendramento a fim de produzir uma configuração particular. Mas há também o que se poderia chamar de explicação narrativa. Para conferir sentido a um conjunto de acontecimentos aparentemente estranhos ou enigmáticos - e vamos pressupor aí incluídas as nossas lendas urbanas -, recorre-se a categorias culturalmente fornecidas, tais como conceitos metafísicos ou crenças místicoreligiosas, no esforço de tornar familiar o não-familiar. Ora, esta segunda modalidade de discurso não é exclusividade do relato ficcional. De fato, ela não é de modo algum alheia ao trabalho do historiador, na medida em que os dados com que trabalha são 
também eles estranhos, nem que seja pelo próprio fato de estarem distanciados no tempo e/ou no espaço em relação à escrita que deles se faz. Conforme aponta White:

“O historiador partilha com seu público noções gerais das formas que as situações humanas significativas devem assumir em virtude de sua participação nos processos específicos da criação de sentido que o identificam como membro de uma dotação cultural e não de outra. No processo de estudar um dado complexo de eventos, ele começa por perceber a possível forma de estória que tais eventos podem configurar. Em seu relato narrativo do modo como este conjunto de eventos assumiu a forma que percebe ser inerente a esse relato, ele [o historiador] urde o seu relato na forma de uma estória de um tipo particular.” (White 1978: 1023)

O leitor, por sua vez, experimenta o efeito de reconhecer no relato a forma genérica - mais ou menos estável, lembremos - que este assume, tendendo a assimilar a estranheza ou exotismo originais dos fatos reportados sob o código de uma narrativa de um tipo particular. Assim, os eventos tornam-se familiares não somente por terem se revelado em sua suposta objetividade, mas também, como argumenta White, por terem se harmonizado com uma estrutura de enredo com a qual o leitor familiarizou-se como fazendo parte de sua dotação cultural.

O que White tenta enfatizar aqui é a formação implícita de uma estrutura dentro da qual podem ser encaixados os eventos de modo a codificá-los sob a forma de tipos diferentes de narrativa. Tal estrutura, sempre em movência, representa necessariamente uma forma de transgressão das normas de objetividade factual esperada de um relato historiográfico ou de uma explicação científica, uma vez que se confundem os limites entre o histórico como dado objetivo apreensível e o possível do narrado, isto é, a narrativa plausível que se possa tecer ao redor desse objeto. Levando o pressuposto ao limite do seu potencial, White dirá que a estrutura evidencia uma distorção inerente a todo modelo teórico, em qualquer campo factual de que o discurso pretende ser a representação (op. cit.: 129).

Nessa conexão, poder-se-ia convocar o pensamento análogo de Michel de Certeau sobre o fazer histórico. Para o historiador, existe no trabalho de escrita da 
história uma revolução fundamental, tributária do momento em que a linguagem e a ideologia passam a ser vistas como inescapavelmente imbricadas - momento em que a prática historiográfica afirma, auto-reflexivamente, a produção de sentido em seu próprio modo de atividade, em seus próprios procedimentos e escolhas, isto é, em suas seriações, suas descontinuidades. Trata-se mesmo de uma revolução fundamental, que "transforma a pesquisa de um sentido desvendado pela realidade observada, em análise das opções ou das organizações de sentido implicadas por operações interpretativas" (1975/1982: 41). Assim sendo, conclui o autor, todo e qualquer "fato histórico” resulta de uma práxis, que já é, ela própria, um signo, a afirmação de um sentido. Por isso, não se pode falar em apreender significados a partir do real, e sim em articulá-los sob um modo de compreensão num “discurso de fatos”.

Avançando um pouco mais essa discussão, sem nunca perder de vista nosso objeto de estudo, poderíamos dizer que todo e qualquer discurso se encaminha em direção a uma estrutura, uma configuração particular da realidade sobre a qual torna-se possível fazer perguntas significativas do tipo: o quê, quando, onde e por quê. E isso se dá, antes de mais nada, porque existe uma dimensão metafórica primeira em todo e qualquer uso da linguagem, tornando-o figurativo ainda que se insinue como relato objetivo e imparcial da realidade. Ainda de acordo com White, mesmo no mais simples relato em prosa, ou na representação supostamente não-mediada de um fato, o uso da linguagem, por si só, projeta uma dimensão figurativa profunda (como uma poética), situada à parte dos próprios “fatos”, a qual prepara o leitor, de maneira mais ou menos consciente, para receber "tanto a descrição dos fatos quanto a sua explicação como sendo plausíveis, de um lado, e mutuamente adequadas, de outro” (1978: 127). É assim com o discurso histórico, e é assim também com o discurso ficcional, na medida em que ambos, cada um a seu modo específico, elaboram na linguagem as metáforas que elegem como sendo as que irão ordenar e dar sentido ao mundo passado, presente e futuro.

Tal concepção da narrativa nos permite, como nos lembra White, considerar uma estória específica como sendo o reflexo dos eventos "tais como ocorreram” ao mesmo tempo em que ela se inscreve num modelo conceitual, um sistema genérico, com o qual se devem codificar os elementos a partir de uma estrutura reconhecível. No entanto, tal estrutura, que poderíamos chamar de canonicidade narrativa, só é mobilizada em função do elemento performático da linguagem, isto é, pelas instâncias enunciativas 
determinadas nas quais os relatos e as narrativas se materializam. Sempre com a relação entre narrativa e discurso histórico em mente, White afirma:

“Um relato narrativo é sempre um relato figurativo, uma alegoria. Desconsiderar esse elemento figurativo na análise da narrativa é ignorar não apenas seu aspecto alegórico mas também a performance na linguagem por meio da qual uma crônica de eventos é transformada em narrativa.” (White 1987: 48)

Falarei mais a respeito do caráter performático da linguagem na segunda parte deste capítulo, quando tratarei das dimensões de estrutura e acontecimento implicadas no discurso das lendas. Antes, porém, proponho explorar um pouco o sentido do termo canonicidade, empregado anteriormente, a partir de escritos mais recentes propostos por Jerome Bruner no campo da psicologia. Trata-se de um pensamento complementar ao dos historiadores citados, e cuja pertinência se presta plenamente à reflexão que venho traçando até aqui.

\subsection{Narrativa e Canonicidade}

Segundo Bruner (1990/1997), num modo de vida culturalmente adaptado como o das nossas sociedades, precisamos de significados e conceitos que sejam partilhados no domínio público. Por mais ambíguo ou polissêmico que nos possa parecer um discurso, é preciso que este seja negociado na esfera pública para que se possa interpretá-lo dentro de um determinado padrão cultural, uma estrutura reconhecível, pré-construída. Como aponta o autor, a psicologia popular - a do senso comum, antimentalista - é investida de uma canonicidade que põe em relevo o caráter usual e previsível da experiência humana. Quando uma determinada forma de discurso parece se encaixar facilmente dentro de uma esfera de previsibilidade - caso, por exemplo, dos clichês, lugares-comuns, ou narrativas ficcionais altamente padronizadas -, tal estrutura se nos apresenta como naturalizada, quase tácita, diante de mais uma instância que reforça suas normas.

Mas, como sabemos, o discurso também pode (e freqüentemente o faz) nos oferecer um elemento de estranhamento, de incomum ou excepcional, com que se deve 
lidar no trabalho de interpretação. Ora, aí reside, segundo Bruner, uma característica de adaptação da canonicidade, uma vez que esta dispõe de meios para interpretar o excepcional e o incomum de forma compreensível. Isto é, a cultura equipa seus membros a lidarem simultaneamente com a excepcionalidade e a convencionalidade. Embora a cultura seja apreendida como dotada de um conjunto de normas, ela deve também oferecer um conjunto de procedimentos discursivos (interpretativos) que permita que seus membros interpretem os desvios que insistem em se operar sobre aquelas mesmas normas. E eles o fazem por meio de narrativas. Nos dizeres de Bruner, a função de uma história (ou narrativa) é encontrar um estado intencional - entendido aqui como uma crença ou um desejo - “que atenue ou pelo menos torne compreensível um afastamento de um padrão cultural canônico” (1990/1997: 50). Estabelece-se, assim, a verossimilhança que permite assimilar a mais estranha história dentro dos limites de uma interpretação aceitável.

O autor vai mais além, ao afirmar que uma narrativa vale a pena ser contada justamente na proporção em que esta vai contra a expectativa de um roteiro canônico. Enquanto a realidade narrativa nos assegura sobre o que é convencional, costumeiro e legítimo, ela deve, para ser legitimada, mais uma vez, tornar estranho o familiar, invertendo assim o processo de “decodificação” da realidade. Certamente, esses desvios da canonicidade podem eles mesmos ser facilmente assimilados, num movimento previsto pelo próprio sistema. Quer dizer, as reviravoltas ocorridas sobre o senso comum acabam por ser identificáveis (até esperáveis) dentro de uma espécie de cumplicidade entre o contador de histórias e os que "se deixam levar" pela inventividade aparentemente singular daquela narrativa específica. Um exemplo banal disso seria o que ocorre com as telenovelas em que o final feliz, tão "legitimamente antecipado”, sofre um contínuo adiamento pela impossibilidade de os protagonistas românticos da trama ficarem verdadeiramente juntos, ou a de os vilões serem punidos ao longo de toda a intriga (recebendo seu merecido e esperado castigo somente no último capítulo).

A assimilação da peripécia na estrutura da canonicidade, no entanto, não poderia ocorrer totalmente a priori, como que prescrita passo a passo em seus desdobramentos. É no ato de contar as histórias - ou no termo que preferimos aqui o tempo todo, na prática discursiva - que se é possível pressentir a sombra da estrutura canônica que paira por sobre as narrativas. É preciso sempre encenar o discurso, enunciá-lo a cada 
vez, no presente, para que a canonicidade pré-construída seja testada em seus limites limites desde sempre projetados numa idealidade e, portanto, fluidos e em constante movência. Num raciocínio análogo a esse, podemos citar Lyotard, quando nos lembra:

“Aquilo a que as narrativas se referem pode parecer pertencer ao passado, mas na realidade ele é sempre contemporâneo ao ato da recitação. É o ato presente que, em cada uma de suas ocorrências, anuncia a temporalidade efêmera que habita o espaço entre o 'eu ouvi” e o 'você vai ouvir'.” (Lyotard 1979/1997: 22)

Podemos concluir daí que, num movimento simultaneamente de retenção e avanço, as "mesmas” histórias são contadas e recontadas sob novos formatos - e susceptíveis a novas interpretações -, mas sempre portando consigo uma marca ou resquício do que já prevalecia antes. Mesmo num mundo em que a sensibilidade para as formas genéricas das histórias possa eventualmente ter atingido um grau máximo de auto-reflexidade, “o 'consolo da narrativa' pode ser sua própria sensibilidade em relação às normas que mudam”, conforme ainda apontaria Bruner em um momento posterior (1996/2001: 137).

\subsection{Narrativa e Intriga}

Outro conceito relacionado à questão da narrativa, e importante para a discussão que se vem desenhando até aqui, é o de intriga (ou enredo), tal como o desenvolve o filósofo Paul Ricoeur nos três tomos de sua obra Tempo e Narrativa (1983/1994; 1984/1995; 1985/1997). De acordo com o autor, ocorre em qualquer narrativa a combinação, em proporções variáveis, de duas dimensões básicas. Uma delas tem a ver com o aspecto cronológico da narrativa, isto é, sua dimensão episódica. A outra tem a ver com a configuração da narrativa, ou seja, a construção de todos coerentes, ou enredos, a partir de eventos dispersos. É essa segunda dimensão que funda a própria condição da historicidade, uma vez que os eventos só são “dignos de narração” na medida em que possam contribuir para o desenvolvimento de uma trama. Como resultado do trabalho interpretativo do historiador, ou do autor de ficção igualmente, os eventos deixam de ser instâncias únicas e singulares da experiência humana e passam a 
assumir um caráter estrutural, formador de um espaço de repetição e memória. Esse ponto de vista proposto por Ricoeur é bem resumido por White, quando afirma que:

"um evento especificamente histórico não é aquele que se pode inserir numa história onde quer que o escritor queira; ele é antes um tipo de evento que pode 'contribuir' para o desenvolvimento de uma intriga. É como se a intriga fosse uma entidade em processo de desenvolvimento anterior à ocorrência de um dado evento qualquer, e qualquer evento pudesse ser investido de historicidade apenas na proporção em que se pode mostrá-lo como contribuindo para esse processo.” (White 1987: 51)

Ricoeur vê na narrativa uma função simbolizante de eventos que indica sua historicidade, alçando os acontecimentos de uma simples relação de estar-no-tempo para uma dimensão de temporalidade ela própria tecida na forma de uma intriga. A narrativa representa os aspectos do tempo pelos quais fins podem ser ligados a meios e a começos formando uma continuidade dentro de uma diferença. A possibilidade de contemplar essa unidade coerente só se realiza em "retrospecto”, como resultado de um esforço interpretativo, e não como uma estrutura já dada que viria se impor autonomamente sobre os acontecimentos narrados.

Ainda segundo o autor, a historicidade não pode ser representada diretamente, mas sim indicada por determinadas narrativas, as quais funcionam como alegorias da experiência de estar-no-tempo na medida em que encenam figurativamente a própria estrutura da temporalidade. E o que mais nos interessa aqui: o raciocínio se aplica não somente ao relato histórico propriamente dito, mas a qualquer estrutura simbólica, incluindo as histórias de caráter mais tradicionalmente ficcional. Isto é, ao relatar um evento histórico ou ao submeter à crença uma determinada narrativa, tanto o historiador quanto o contador de histórias necessariamente revelam uma intriga. Uma intriga que media o acontecido no tempo e o estruturado na memória.

Assim, dentro desse raciocínio, creio que é possível afirmar que quando nos deparamos com uma lenda urbana, podemos lançar sobre ela as mesmas perguntas que poderíamos lançar sobre um relato histórico: que vínculo ela estabelece entre um presente (enunciado, relatado por meio de uma instância única) e um passado 
(rememorado, constitutivo de uma memória)? E que sentidos “promete” para o futuro em função desse mesmo vínculo? Enfim, em que intriga ela está tecida?

Podemos observar pontos em comum entre as três abordagens teóricas apresentadas anteriormente. Primeiro, há em todas elas o entendimento de que a narrativa é um fator simbolizante da experiência humana que se faz presente tanto num relato mais supostamente objetivo e factual da realidade - notadamente o relato histórico - quanto no relato ficcional, lendário ou literário. A narrativa é, assim, um modo de estruturar a experiência e de fazer sentido do mundo que nos cerca. Outro ponto em comum entre as abordagens é a proposta de que há uma certa canonicidade, um arcabouço de narrativas consolidadas sócio-culturalmente, ao qual se pode recorrer para fazer sentido daquilo que não nos parece familiar à primeira vista. Como bem sintetiza uma das epígrafes deste capítulo, “aquilo que não pode ser explicado é em princípio possível de ser entendido" e tal entendimento "nada mais é que sua representação [ou simbolização] na forma de uma narrativa” (White 1987: 54). Trata-se de um mecanismo que garante que o estranho seja assimilável, que o novo se encaixe em um molde já-pré-construído, mas sempre de modo a deslocar uma impossível e nunca concretizável “fixidez absoluta” desse molde.

Assim é que entra em consideração o papel da enunciação, que atualiza o préconstruído em narrativas sempre novas sobre um curso de acontecimentos (históricos ou não) - ou seja, narrativas únicas a partir de um mesmo histórico. Nesse contexto, situo a afirmação de Ricoeur segundo a qual:

"entre uma narrativa e um curso de acontecimentos, não há uma relação de reprodução, de reduplicação, de equivalência, mas sim uma relação metafórica: o leitor é dirigido para a espécie de figura que assimila (liken) os acontecimentos relacionados a uma forma narrativa que nossa cultura tornou familiar para nós.” (Ricoeur 1985/1997: 258)

Mas precisamos ainda avaliar mais especificamente o que tem sido dito sobre lendas urbanas enquanto narrativas. Como as idéias dos autores aqui discutidos se relacionam com o que os estudiosos das lendas têm proposto em relação a essa questão? 


\subsection{Lendas em Narrativa}

O folclorista Bill Ellis (2001: 6-12) lança a aparentemente simples questão: uma lenda é uma narrativa? Se considerarmos que uma narrativa é caracterizada por fórmulas convencionais de começo, meio e fim, e que ela simplesmente segue enredos coerentes e convencionalizados, a resposta é não. Vimos, quando tratamos do gênero no Capítulo 1, como a lenda pode ser um desdobramento apenas um pouco mais elaborado de um rumor, ou como pode se confundir com uma notícia de jornal curiosa ou inusitada. Vimos também como a lenda pode se insinuar dentro de uma conversa circunstancial, ou alguma outra prática discursiva que não se reduza a "contar uma história”.

Revendo estudos recentes que buscam em teorias da narrativa um suporte para o entendimento das lendas, Ellis aponta para a distinção entre, de um lado, o texto da lenda com todas suas especificidades lingüísticas e em sua dimensão de performance individualizada - o que se denomina, em certa tradição européia, o sjuzhet da lenda - e, de outro, uma suposta "estrutura profunda" - ou fabula - subjacente à performance individual, a qual remeteria sempre a algum "motif” conhecido, já manifesto em tantos outros textos.

Tal distinção, no entanto, tem se tornado cada vez menos sustentável, à medida em que as noções mesmas de "estrutura profunda" ou "histórias básicas" são postas em questão. Ellis cita, em particular, a reserva expressa pela crítica literária Barbara H. Smith sobre essas noções, que revelar-se-iam mais como artefatos metodológicos de certos folcloristas que tendem a valorizar uma suposta matriz original dos textos em detrimento do caráter material (enunciativo) das performances das lendas. A autora toma como exemplo a história de Cinderela, que há gerações circula em diferentes versões, em diversos lugares do mundo. Procurar "a” versão original e definitiva do conto, argumenta, seria ignorar o fato de que sua versão padrão se submeteu a critérios relacionais específicos, mas arbitrários, que se consolidaram dentro de uma dada tradição, por alguma comunidade em particular, com seus valores particulares.

Isso não significa de modo algum que o conceito de narrativa se revele inoperante para fins de estudo das lendas. Ao contrário, como sugere o folclorista europeu Henrik Lassen, se supusermos, a partir de uma perspectiva pragmática, a existência da narrativa como um conceito operacional, e usarmos a construção abstrata 
da estrutura narrativa como um meio viável para identificar aquilo que torna diferentes as versões, variantes e performances individuais das lendas - ao invés de meramente especular sobre os temas compartilhados por essas lendas - "a idéia de estrutura narrativa pode, então, funcionar como um conceito capacitante, uma ferramenta válida e efetiva” (1998 apud Ellis 2001:7).

Dessa maneira, Lassen vê na idéia de tradição, de estrutura narrativa, um elemento heurístico-pragmático, isto é, um meio para determinado fim, antes que propriamente uma forma de conhecimento em si mesma. Para ele, a idéia de "iterabilidade" faz sentido apenas na medida em que lança uma luz sobre as características mais ou menos singulares das diversas versões das narrativas. E não o contrário. Sua proposta, portanto, aponta para o processo da narração - e não seu conteúdo - como o verdadeiro foco de atenção crítica nos estudos sobre as lendas.

Também está se levando em conta aí, bem entendido, o papel fundamental dos sujeitos que recebem e interpretam (visto que produzem, também eles, sentido sobre) as narrativas - sujeitos estes que supostamente compartilham dos interesses e dos pressupostos de sentido da comunidade em que circulam as narrativas. A antropológa norte-americana Elizabeth Bird aponta para a importância de se considerar os anseios e os medos específicos das comunidades em que se transmitem determinadas narrativas, lembrando que aquilo que nos soa inusitado ou inusual não se explica aleatoriamente, mas sim por meio de narrativas que apresentam uma relevância cultural para aquelas comunidades. A autora cita W.F.H. Nicolaisen, que, ecoando o pensamento de White sobre a centralidade da narrativa no trabalho de estruturação da experiência, afirma: “[A]s histórias fazem a realidade. Elas mostram que os eventos têm estrutura e não simplesmente seqüência.” (1985 apud Bird 2002: 528). Assim, como resultado de uma espécie de impulso para narrar, os eventos aparentemente aleatórios da experiência humana são investidos de uma certa estruturalidade que se coloca à disposição de uma cultura como parte de seu repertório discursivo.

Especificamente no caso das lendas urbanas, podemos mobilizar ainda a tese defendida por Carl Lindahl (1996 apud Trubshaw 2002: 79-80) de que o papel de intérpretes que os ouvintes (ou leitores) das lendas contemporâneas são instados a assumir é uma condição essencial do processo discursivo das lendas, uma vez que estas são freqüentemente transmitidas sob a forma moderna de "estruturas elípticas de enredo”, isto é, formas fragmentadas de narrar que exigem um alto grau de 
pressuposição e conhecimento de fórmulas genéricas. Mais que propriamente seu conteúdo, esse grau de interação entre os sujeitos envolvidos na prática discursiva é tido por Lindahl como provavelmente o aspecto mais definidor do gênero.

Ora, as visões de Lassen, Bird e Lindahl estão em certo ponto afinadas com a tese que venho defendendo até aqui de que é preciso olhar para as lendas como práticas discursivas, instâncias concretas de uso da linguagem por sujeitos sócio-históricoculturalmente situados - no caso específico, instâncias de transmissão e recepção de lendas contemporâneas por escrito em um meio eletrônico. Trata-se, enfim, de investigar o processo (contínuo, sempre em andamento) antes que propriamente o produto (um texto supostamente fechado ou um "núcleo profundo” recuperável pelo trabalho da interpretação).

Creio, porém, que é preciso, nessa altura da discussão, retomar um pouco a proposta hermenêutica de compreensão da narrativa proposta por Ricoeur e contrastá-la com essa visão mais pragmática da estrutura narrativa - sobretudo em Lassen - para colocar a questão em maior perspectiva. Quando Ricoeur avança a noção de intriga como sendo uma espécie de fio condutor e estruturante da experiência humana, materializável sob a forma de narrativa(s), não parece estar de forma alguma minimizando o elemento enunciativo - de acontecimento - dessas narrativas em nome de uma estrutura globalizante. Vimos mesmo como, para esse autor, qualquer forma de relato, inclusive o mais banalmente cronológico, remete inescapavelmente a uma historicidade, a um já-dito (já-contado) sem o qual os sujeitos dificilmente fariam sentido de o que quer que fosse. Ao estarmos situados em uma cultura, uma sociedade determinada, somos inevitavelmente atravessados por um conhecimento dessas formas recebidas de fazer sentido do mundo, às quais só poderíamos ter acesso, em termos concretos, por meio de narrativas, ou seja, histórias mesmas que são contadas para nós e que nós contamos a outros ao longo de uma vida, mas sempre, é claro, sob a feição do acontecimento vivo, da narração que fazemos aqui e agora - e, portanto, sempre diferentemente - dessas histórias. Em uma relexão análoga, Fabrício nos lembra que, ao contarmos uma história, estamos não somente organizando discursivamente a experiência, mas também “fazendo correlações entre eventos e projetando e atribuindo novos significados para um conjunto de incidentes (reunidos segundo determinados parâmetros de pertinência), para nós mesmos e para os outros” (2006: 206). Estamos, 
enfim, nos posicionando em relação às expectativas sociais e culturais da comunidade discursiva da qual participamos (op. cit.: 200-1).

Não se trata, conseqüentemente, de opor forma e conteúdo, substância e matéria, narrado e narrável. Estamos falando de coisas imbricadas, inseparáveis. Um texto ou acontecimento enunciativo irá sempre apontar, no momento mesmo em que se colocar disponível para leitura, sob a égide de uma iterabilidade que o torna histórico. Uma iterabilidade que é estrutural, e não mera repetição. Tal movimento, pressuposto pela idéia de historicidade apresentada por Ricoeur, a propósito, encontra eco no pensamento de Derrida que, ao discutir a relação entre texto, repetição e história, aponta:

“... a estrutura de um texto... sua iterabilidade... ao mesmo tempo em que finca raízes na unidade de um contexto, imediatamente abre esse contexto não-saturável para uma recontextualização. Tudo isso é histórico do começo ao fim. A iterabilidade do traço (unicidade, identificação e alteração na repetição) é a condição da historicidade." (Derrida 1992: 63)

Em outras palavras, a historicidade se constrói pela possibilidade mesma de repetição das intrigas com que elaboramos a experiência humana em sociedade.

Para concluir esta seção, lanço mão do pensamento do sociólogo francês Emmanuel Taïeb, que julgo sintetizar bem a reflexão sobre a relação entre lendas e narrativa que vem se delineando até aqui. Analisando especificamente o rumor e sua persistência na época das tecnologias eletrônicas, o autor chega à conclusão de que, sendo porosas as fronteiras que distinguem os gêneros narrativos (lendas contemporâneas, rumores, correntes, fait divers), seria mais produtivo e interessante analisar o sistema narrativo que engendra tais gêneros. Para Taïeb, uma narrativa não existe isolada, mas sim dentro de uma estrutura narrativa que se prolonga pelo tempo e que é duplamente constituída (2001: 267).

De um lado, a estrutura indica o estoque (ou repertório) de histórias e narrativas disponíveis em uma dada sociedade - incluindo aí filmes, peças, artigos de jornais - as quais dialogam entre si, desmentindo-se, reforçando-se, incorporando-se umas às outras, num jogo de permanente intertextualidade. O envio de correntes mágicas por e-mail, por exemplo, só fará sentido se os interlocutores considerarem tal prática como familiar, isto é, se tiverem sido expostos a outras correntes semelhantes. Também é o caso dos 
rumores que fazem referência a outros rumores seus contemporâneos ou, mais explicitamente, o caso das paródias de lendas urbanas que circulam na Internet. Só fazem sentido dentro de uma memória compartilhada.

De outro lado, essa estrutura narrativa constitui-se no espaço que se abre para que um relato possa evoluir, desdobrar-se, passar de uma modalidade a outra. Assim poder-se-ia explicar como uma determinada narrativa se transmuta, por exemplo, de rumor a notícia, de notícia a lenda urbana, de lenda urbana a obra de ficção, de obra de ficção a paródia, quebrando as barreiras invisíveis que se tentam impor entre os gêneros narrativos. De fato, é possível verificar com freqüência que "gêneros inteiros se cruzam e se assimilam entre si, como se formassem um ciclo da palavra que jamais devesse se romper” (Taïeb 2001: 268). Ora, o que temos aqui, então, se não mais uma vez o reforço da noção de prática discursiva, sustentada dialeticamente por movimentos de arquivamento - em todas as suas metáforas relacionadas, às quais já nos referimos em algum momento anterior: arcabouço, memória, canonicidade - e movimentos de atualização - e também suas metáforas correspondentes: fluxo, corrente, enunciação?

\section{Estrutura e Acontecimento}

Acredito que nossa reflexão vem fluindo cada vez mais na direção de se considerar a prática discursiva da lenda urbana como possuindo um caráter (sempre) duplamente articulado. Dedicarei, pois, a segunda parte deste capítulo à investigação, por meio de outros cruzamentos teóricos, dessa dupla articulação, à qual me referirei daqui para diante, para fins de nossa hipótese central, como a tensão entre a estrutura e o acontecimento enunciativo.

\subsection{Estrutura versus Acontecimento?}

Como vimos anteriormente, Ricoeur propõe a idéia de intriga como elemento estruturante das narrativas. Ela se constrói sob a forma de acontecimentos que se relacionam entre si de forma tanto a confirmar quanto a deslocar a norma. O autor reformula os postulados epistemológicos implícitos no uso corrente que fazem os historiadores do termo acontecimento - isto é, como sinônimo de singularidade e 
contingência absolutos - buscando salientar aquela conexão primordial que acredita haver entre acontecimento e narrativa por meio da intriga. Os acontecimentos recebem uma inteligibilidade, ou seja, só “fazem sentido" na medida em que contribuem para a progressão da intriga, o que exige um redimensionamento das noções de singularidade e contingência.

Dentro desse raciocínio, Ricoeur defende que as intrigas são ao mesmo tempo singulares e não singulares: narram acontecimentos que só ocorrem nessas intrigas, e que portanto não se encaixam automaticamente nos paradigmas disponíveis, mas tendem ao mesmo tempo a armar-se como novos paradigmas, universalizando aqueles acontecimentos que as compõem. Assim, as intrigas combinam ao mesmo tempo desvio e conformidade aos paradigmas. Escreve o autor:

“O processo de tessitura da intriga oscila entre a conformidade servil em relação à tradição narrativa e a rebelião em relação a qualquer paradigma recebido. Entre esses dois elementos, estende-se toda a gama das combinações entre sedimentação e invenção. Os acontecimentos, quanto a isso, seguem o destino da intriga. Também eles seguem a regra e quebram a regra, sua gênese oscilando de um lado e do outro do ponto médio da ‘deformação regrada'.” (Ricoeur 1983/1994: 295)

O que Ricoeur basicamente propõe nessa discussão é que os acontecimentos, pelo fato mesmo de serem narrados, serão sempre e simultaneamente únicos e típicos, contingentes e previsíveis, desviantes e tributários de paradigmas, quer isso se dê de modo deliberado (por exemplo, numa paródia ou narrativa de teor irônico) ou não (caso das narrativas históricas ou jornalísticas, que, ao buscarem a objetividade no relato dos fatos, acabam por mascarar essa própria articulação). Postular uma cisão entre acontecimento e estrutura como sendo substâncias independentes torna-se, sob o prisma da teoria da narrativa de Ricoeur, uma tarefa pouco produtiva.

E é numa esteira bastante semelhante à desse autor que caminha um pensamento vindo de outro campo de investigação, a antropologia cultural representada pelo norteamericano Richard Sahlins, cujas idéias centrais apresento a seguir.

Sahlins identifica em uma certa tradição dos estudos antropológicos e históricos um movimento que tende a isolar determinados eventos - marcos, alterações no painel 
da história e da cultura - e opô-los à estrutura - matriz que estabelece o padrão de continuidade da história e da cultura. Ora, tal oposição, julga o autor, revela-se perniciosa pelo simples motivo de que "toda estrutura ou sistema [já] é sempre eventual”, isto é, só se verifica em termos empíricos por meio dos eventos, dos usos particulares que dela fazem os sujeitos sócio-histórico-culturalmente situados. Mais significativa (e talvez um pouco mais difícil de reconhecer), no entanto, é a proposição inversa, segundo a qual "todos os acontecimentos são culturalmente sistemáticos” (1985/1990: 190).

Com efeito, um evento é um acontecimento dotado de significância, e enquanto tal, depende da estrutura para produzir seus efeitos. Um evento não pode ser tomado simplesmente como um acontecimento isolado da experiência com o mundo, mas sim em relação à estrutura simbólica que permite que ele apareça e se torne significativo. Ressalta Sahlins:

"[A]pesar de um evento enquanto acontecimento ter propriedades 'objetivas’ próprias e razões procedentes de outros mundos (sistemas), não são essas propriedades, enquanto tais, que lhe dão efeito, mas a sua significância, da forma que é projetada a partir de algum esquema cultural. O evento é a interpretação do acontecimento, e interpretações variam.” (op. cit.: 190-1)

Conclui-se daí que não se pode entender os eventos separados de seus valores. Os eventos são sempre interpretados, ou como diria Ricoeur, armados-em-intriga. É assim que uma separação essencialista entre estrutura e evento (acontecimento com significância) se apresenta mais como um ato de vontade, um esforço metodológico, que propriamente uma descrição objetiva da realidade.

E é dessa forma também que Sahlins vê na dinâmica das práticas de agentes situados a própria possibilidade de transformação de categorias e valores culturalmente estabelecidos. Para explicar essa dinâmica, o autor propõe o conceito de estrutura da conjuntura ("structure of the conjuncture"), segundo o qual os sujeitos, embora motivados em suas ações e relações por categorias convencionais recebidas da cultura em que se situam, podem eventualmente re-significar essas categorias, conferindo-lhes novas interpretações e agindo sobre elas de modo não (necessariamente) previsível. 
Forma-se, assim, um ciclo em que a estrutura se projeta sobre o contexto, que por sua vez, por meio das práticas, realimenta a estrutura, dando-lhe uma nova configuração.

Tal dinâmica explicaria as contradições e conflitos gerados, por exemplo, a partir do contato entre os europeus e os chefes e povos do Havaí nos séculos XVIII e XIX que, num primeiro momento, se deu de acordo com as autoconcepções e habituais interesses de ambas as partes - num movimento, portanto, de reprodução da cultura recebida - mas que inevitavelmente evoluiu, por efeito das condições específicas desse contato, para o desenvolvimento de formas não previstas nas relações tradicionalmente prescritas, o que resultou em novas categorias funcionais e uma conseqüente reconfiguração da estrutura. Donde, “os valores adquiridos na prática retornam para a estrutura como novas relações entre suas categorias” (Sahlins 1981: 50).

A suposta dicotomia existente entre estrutura e acontecimento viria a ser problematizada mais explicitamente pelas teorias pós-estruturalistas, as quais se propunham a reavaliar o primado da estrutura na base do pensamento lévi-straussiano. Para o estruturalismo, a estrutura preexistiria ao acontecimento: as regras, a gramática e mesmo a ideologia sobredeterminariam os acontecimentos, os quais se constituem como marcações pontuais. A estrutura, assim, ditaria o que o acontecimento significa, ou mesmo se ele é digno ou não de significar (ter significância). A história, por exemplo, tida como uma progressão linear do tempo, configuraria uma estrutura idealizada, invariável e homogênea, uma vez que se a enxerga como reflexo transparente dos fatos da realidade. Os eventos históricos, dessa forma, seriam o próprio modo de acesso à estrutura. Eles, por assim dizer, evidenciariam, ou confirmariam, a estrutura.

Ora, acontecimentos são sempre-já inseridos em uma estrutura. Não há possibilidade de se enxergar um acontecimento sem que esteja necessariamente dentro de uma estrutura. No entanto, quando se atenta para as condições específicas de produção dos acontecimentos (a história, o contexto amplo) percebe-se como as estruturas são diferentes para as diferentes comunidades interpretativas, isto é, os diferentes agentes que descrevem e constroem a estrutura. O que nos permite concluir que sempre haverá acontecimentos e estruturas, porém o elo entre eles vai depender sempre do local de enunciação a partir do qual se interpretam as estruturas. Um mesmo evento é compreendido de diferentes maneiras na medida em que se situa em diferentes 
estruturas de interpretação (uma estrutura científico-racional, por exemplo, em oposição a uma estrutura místico-religiosa).

De qualquer maneira, a ligação entre estrutura e acontecimento permanece sempre no trabalho da significação. O que freqüentemente ocorre é que as diferentes comunidades interpretativas buscam atribuir universalidade às suas próprias estruturas, tratando-as como se fossem a-históricas. As estruturas nunca são a-históricas; elas se modificam constantemente (e potencialmente) a cada ato de re-significação de um determinado evento. Em outras palavras, o evento é sempre capaz de modificar a estrutura, ainda que gere a ilusão de imutabilidade e a-historicidade dessa mesma estrutura ${ }^{14}$.

Como não poderia deixar de ser, encontraremos também nas reflexões sobre linguagem como discurso uma discussão sobre a tensão entre estrutura e acontecimento. Por ser essa uma discussão de relevância mais direta aos propósitos deste trabalho, faço em seguida uma breve exposição de como ela se deu ao longo da trajetória da Análise do Discurso de linha francesa (AD), de um "primeiro" Michel Foucault a um "último” Michel Pêcheux.

\subsection{Estrutura e Acontecimento no Discurso}

Em seu A Arqueologia do Saber (1969/2004: 28-32), Foucault busca já identificar como os acontecimentos discursivos, sob a forma de enunciados, possibilitam o surgimento, o estabelecimento e a consolidação de certos objetos de saber em nossas sociedades. Tais acontecimentos discursivos representam o conjunto de todos os enunciados efetivos - tanto os falados quanto os escritos - em sua instância única de ocorrência irrepetível. Trata-se de descrever esse conjunto finito e limitado de seqüências em sua irrupção histórica, isto é, em sua singularidade eventual cujo significado não se encerra na descrição lingüística de suas propriedades semânticas.

Os acontecimentos discursivos, embora finitos, não são, no entanto, independentes. Estão necessariamente ligados a outros enunciados pelo trabalho histórico do sentido. Os acontecimentos são, de um lado, um gesto único e irrepetível,

\footnotetext{
${ }^{14}$ Devo grande parte dessas reflexões acerca das teorias pós-estruturalistas a anotações colhidas em disciplinas que cursei nos programas de mestrado e doutorado nesta faculdade - em especial "Narrativas e Identidade”, ministrada pelo professor Lynn Mario T. M. de Souza - e à leitura de Derrida (1967/2002; 1972/2001b.) e Smart (1996).
} 
e, de outro, evidências de uma memória à qual se ligam tanto na direção do passado (o já-dito) quanto do futuro (o devir).

Para esse aspecto Pêcheux chamou especialmente a atenção ao revisar a influência desse primeiro momento na obra de Foucault dentro da trajetória das teorias de Análise do Discurso (AD) desenvolvidas na França desde o final da década de 1960. Especificamente, a idéia de formação discursiva, tal como havia sido interpretada numa fase inicial daquela disciplina - a saber, o conjunto de enunciados que podem e devem ser ditos em determinada configuração discursiva - levara, segundo Pêcheux, a uma certa distorção. Antes de ser tomada dialeticamente como força de filiação $e$ dispersão, a formação discursiva parecia constituir-se como uma verdadeira máquina de assujeitamento voltada à repetição, na medida em que todo acontecimento discursivo tenderia sempre ao apagamento, ou absorção, àquela estrutura. Ciente dessa distorção, Pêcheux propôs recuperar uma visão descontínua de história e discurso, que estivera presente o tempo todo na base do pensamento foucaultiano, para formular uma visão de acontecimento como ruptura, uma espécie de (sempre nova) agitação da estrutura que força esta a (constantemente) se reconfigurar . E é assim que surge a sua freqüentemente citada formulação:

“[T]odo discurso é o índice potencial de uma agitação nas filiações sócio-históricas de identificação, na medida em que ele constitui ao mesmo tempo um efeito dessas filiações e um trabalho (mais ou menos consciente, deliberado, construído ou não, mas de todo modo atravessado pelas determinações inconscientes) de deslocamento no seu espaço." (Pêcheux 1983/1997: 56)

Conclui-se daí que as formações discursivas, enquanto estruturas, só podem ser entendidas como configurações heterogêneas - divididas entre a regularidade e a diversidade, a unidade e a diversidade -, uma vez que se remetem necessariamente umas às outras, sendo constituídas, de modo paradoxal, a partir de seu exterior. Assim, quando se trata de apreender a dinâmica das estruturas, ou seja, identificar os acontecimentos que as materializam em determinadas práticas, é preciso insistir sobre esse caráter irredutivelmente heterogêneo, que traz a alteridade para dentro do mesmo, fazendo com que se desestabili[ze] a garantia de homogeneidade sociohistórica de um corpus” (Grigoletto 2002: 31). 
De fato, Pêcheux amplia, numa última fase de seu trabalho, a noção de acontecimento discursivo. Conforme bem sintetiza De Nardi, o acontecimento aparece aí como um princípio organizacional, uma vez que pode ser abordado simultaneamente sob duas perspectivas: no contexto de uma presença/evidência e no espaço de uma memória, por ele retomada e reorganizada. Assim, o acontecimento remete sempre a uma transparência, “um dizer que não poderia ser, naquele momento, senão aquele”, e a uma opacidade, "porque carrega consigo uma série de práticas anteriores que possibilitaram sua eclosão (ou tentaram impedir seu aparecimento)” (2004: 4-5).

Tais concepções de acontecimento discursivo se aliariam, de certa forma (e ressalvadas as diferenças), à visão enunciativa na linha de Benveniste e Ducrot, que enfatizavam o enunciado em sua singularidade irrepetível. No entanto, conforme aponta Possenti (2004: 379), a AD parece ter privilegiado o elemento repetível, estrutural dos acontecimentos, os quais, embora nunca completamente assimiláveis a um efetivamente já-dito, estão sempre sujeitos a inscrever-se numa rede de memória, num trajeto histórico-social que eles contribuem para tecer.

O conceito de memória revela-se, nessa junção, um eixo central para entendermos a tensão entre estrutura e acontecimento (além de estar ligado à própria definição de discursividade). Em um outro texto, ainda de 1983, Pêcheux se dedica à questão, apontando para o caráter estruturante da materialidade discursiva que a memória possui, sendo entendida em uma dialética da repetição e da regularização. Escreve o autor:

"[A] memória discursiva seria aquilo que, face a um texto que surge como acontecimento a ler, vem restabelecer os 'implícitos' (quer dizer, mais tecnicamente, os pré-construídos, elementos citados e relatados, discursos-transversos, etc.) de que sua leitura necessita: a condição do legível em relação ao próprio legível.” (Pêcheux 1983/1999: 52)

O local onde se iriam encontrar esses pré-construídos não seria, no entanto, um arquivo imediatamente acessível, como um fundo de memória coletiva permanente, à espera de um resgate. Antes de ser concebida como uma "esfera plena, cujas bordas seriam transcendentais históricos e cujo conteúdo seria um sentido homogêneo, acumulado ao modo de um reservatório”, a memória deve ser vista como possuindo 
um caráter móvel, heterogêneo e não meramente acumulativo, constituindo-se como um “espaço de desdobramentos, réplicas, polêmicas e contra-discursos” (op. cit.: 56).

Pêcheux acompanha Pierre Achard (1983/1999) na hipótese de que a presença da repetição em uma seqüência discursiva seria responsável pela formação de um efeito de série a partir do qual se iniciaria uma regularização. Estariam aí localizadas, nessa própria regularização, as diversas manifestações do pré-construído: remissões, retomadas, citações, paráfrases, comentários, paródias...

Mas tal regularização, longe de se sedimentar numa edificação sólida e estável, "é sempre susceptível de ruir sob o peso do acontecimento discursivo novo, que vem perturbar a memória” (Pêcheux 1983/1999: 53). O que isso significa? Que sempre novas séries podem se configurar retrospectivamente, que sempre novos cruzamentos podem ser tecidos a partir da irrupção de novos acontecimentos, o que impede que a regularização se estabeleça de um modo linear e uniforme. Num jogo de forças que visa a manter uma regularização preexistente, os acontecimentos tendem, assim, a ser absorvidos pelo sistema, que, por sua vez, já não pode permanecer idêntico a si mesmo, pelo resultado dos deslocamentos provocados por aqueles mesmos acontecimentos.

Se pensarmos nos acontecimentos discursivos como paráfrases sempre novas desse mesmo pré-construído, veremos que eles se apresentam como evidências de uma falta, um vazio constitutivamente impreenchível - o que, de resto, caracteriza o próprio trabalho da linguagem como discurso. Isso porque o discurso só se constrói pelo encontro de uma memória do dizer - ou seja, o interdiscurso, que é o conjunto do dizível historicamente constituído, exterior e anterior ao sujeito - e uma atualidade enunciativa - ou seja, o movimento de dispersão do sujeito no discurso, de seu investimento ideológico sobre o já-dito, sob a forma de novos/repetidos dizeres.

Uma visão que contemple o discurso não só como estrutura, mas também como acontecimento, parece-me, dessa forma, bastante pertinente para os fins deste trabalho. Ela traz para o centro da discussão, como bem apontam Grigoletto (2002: 39-41) e Gregolin (2005: 24-7), a possibilidade de vislumbrar nas seqüências discursivas - no caso aqui, os recortes que compõem nosso corpus - o primado do interdiscurso, isto é, a incidência dos diversos dizeres regularizados por uma memória minimamente identificável, mas sempre fluida, sujeita aos embates que os acontecimentos discursivos vêm a impor numa totalidade que nunca se encerra. Uma totalidade inatingível, afinal, pois assim o é o próprio trabalho do sujeito com a linguagem. 


\subsection{Estrutura e Acontecimento nas Lendas Urbanas: uma breve retomada}

Parece-me válido neste momento lançar um olhar retrospectivo sobre o que já foi dito até aqui sobre nosso objeto de estudo e a partir daí fazer uma espécie de pequeno balanço das idéias apresentadas, tomando-as pelo viés dessa relação fundamental entre a estrutura e o acontecimento.

Começaria pela questão da definição do gênero lendas urbanas. Vimos como a tentativa de identificar traços comuns a essas narrativas esbarra constantemente na intersecção com outros gêneros semelhantes, como os rumores e os fatos curiosos. Ou seja, a tentativa de encontrar um sistema, uma estrutura que caracterizasse o gênero, tem de conviver forçosamente com o efeito elusivo gerado pelos acontecimentos dentro de uma prática discursiva. Poderíamos dizer que as lendas urbanas só poderiam ser reconhecidas como gênero na medida em que os membros de uma determinada comunidade - no nosso caso, um grupo de discussão na Internet - investissem suas interpretações naquilo que consideram como sendo o que pode ou deve ser dito, ou, por oposição, o que não pode e não deve ser dito sobre seu objeto. Ao discutir mais ou menos explicitamente o que se encaixaria na categoria lenda urbana e o que não se encaixaria, os membros dessa comunidade estariam, na verdade, arbitrando sobre os limites da própria prática, cercando suas possibilidades, circunscrevendo nessa própria prática o objeto que, de resto, não existe a priori, como fazendo parte de um "arquivo folclórico/enciclopédico” situado fora dessa própria prática que lhe dá vida e forma.

Ora, tal investimento interpretativo poderia ser associado com aquilo que Dominique Maingueneau denomina competência interdiscursiva, dispositivo por meio do qual os sujeitos são capazes de "reconhecer a incompatibilidade semântica de enunciados da(s) formação(ões) do espaço discursivo que constitui(em) seu Outro”, bem como "interpretar, traduzir esses enunciados nas categorias de seu próprio sistema de restrições”, atestando a "irredutível descontinuidade que funda o espaço discursivo” (1984/2005: 56-7).

Trata-se, portanto, de reconhecer a alteridade, o caráter incontornavelmente heterogêneo (interdiscursivo, intertextual, polifônico...) de qualquer gênero, ao mesmo tempo em que se é capaz de identificar um "corpo estranho”, de banir um ou outro texto da prática por ele estar fora de um "cânone” afinal nunca definitivamente estabelecido. Isso se evidenciaria, por exemplo, na necessidade de intervenção de um 
mediador ou o confronto entre novatos e veteranos dentro da comunidade virtual (lista de discussão) a respeito do pertencimento - a validade ou relevância - de determinadas mensagens naquele espaço circunscrito.

O que nos remete mais uma vez à discussão sobre as condições de produção do discurso que compõe nosso corpus, empreendida ainda no Capítulo 1. Lá pude fazer um levantamento de mecanismos que, segundo a "tipologia” de Foucault, contribuem para o cerceamento e a regulação dos dizeres. Dentre esses mecanismos, destaquei a prática do comentário, observando como este se desenvolve em uma relação complexa, de aparente contradição, entre o que já foi dito e o que está a se dizer "pela primeira vez”. Estamos obviamente diante de mais um matiz possível da tensão entre sistema e ocorrência. Segundo aquela relação, as múltiplas retomadas de lendas urbanas sob novas e sempre atualizadas versões, bem como os múltiplos acontecimentos “comentadores” das mensagens que veiculam as lendas urbanas no grupo de discussão, acenam para uma permanente expansão do discurso, a saturação de um sistema anônimo que no entanto se projeta na enunciação como um espectro, uma matriz a ser observada, senão "preservada”.

É esse um movimento que, como diria Derrida (1967/2002), busca um centro para a estrutura - esquecendo, num mesmo golpe, de que esse centro só pode ser ocupado provisoriamente, uma vez que a estrutura é sujeita ao jogo, isto é, ao deslocamento permanente desse espaço pretensamente sólido que é o centro. Em outras palavras, a multiplicação dos acontecimentos sob a forma do comentário, enquanto agita as estruturas, não deixa de apontar, como num movimento oposto, para a falta ou esquecimento constitutivos do próprio processo de significação, cujo assentamento desejado depende, fundamentalmente, do efeito de apagamento da estruturalidade da estrutura, ou seja a possibilidade de se entender a estrutura não como um lugar fixo, mas como uma função a preencher - ela sempre também sujeita ao jogo ${ }^{15}$.

Já no presente capítulo começamos a aprofundar a reflexão sobre as lendas urbanas enquanto narrativas, dotadas de uma estrutura de enredo que atravessa

\footnotetext{
15 A reflexão de Derrida se estende, aliás, à toda a história metafísica, logocêntrica, do conceito de estrutura, que sofre uma ruptura a partir do momento em que se passa a pensar " $a$ lei que comandava de algum modo o desejo do centro na constituição da estrutura, e o processo da significação ordenando os seus deslocamentos e as suas substituições a essa lei da presença central; mas de uma presença central que nunca foi ela própria, que sempre já foi deportada para fora de si no seu substituto” (1967/2002: 232). Substituto esse nunca inteiramente "novo" em relação ao substituído, uma vez que de algum modo já lhe preexistia. É nesse sentido que, para Derrida, pode-se pensar o centro como um não-lugar, um espaço projetado onde se realizam substituições indefinidas de signos.
} 
diferentes textos em diferentes versões. Àquela discussão poderíamos acrescentar a hipótese de, que por serem geradas no seio da vida cotidiana, trazendo elementos que fazem parte desse cotidiano de um modo bastante acessível mas que em muitos casos representam ameaças novas e impensadas, as narrativas elaboram enredos (intrigas) identificáveis em combinações potencialmente variadas. Isto é, multiplicam-se nas narrativas contemporâneas as possibilidades de acontecimentos proto-lendários na medida mesma em que elas não precisam buscar numa ordem sobrenatural ou declaradamente fantasiosa o material de que são feitas.

As lendas urbanas diferenciam-se, assim, da maior parte das narrativas normalmente associadas ao folclore tradicional, onde as possibilidades de variação e mesmo de "verossimilhança” parecem mais reduzidas. Claro, verossimilhança é entendida aqui em termos do "efeito de realidade" gerado pela familiaridade com os temas e motivos que povoam as lendas urbanas - contaminação de alimentos, acidentes com produtos da tecnologia moderna, ameaças vindas do estrangeiro, para citar alguns dos exemplos a serem analisados na Parte II -, mais do que propriamente pela configuração bastante particular, freqüentemente "inacreditável", de cada um dos acontecimentos relatados. Bem ao encontro desse pensamento, evoco, para concluir esta revisão, as palavras de Jean-Bruno Renard, que propõe:

“[O]s relatos lendários são o produto de uma dupla determinação, eventual e mítica: os eventos fornecem os pontos de ancoragem no real, a verossimilhança e as causas imediatas da lenda, enquanto que os modelos míticos impõem uma estrutura narrativa $e$ de motivos temáticos, freqüentemente imemoriais”. (Renard 1999/2006: 84)

Irei enfocar, dentre outras questões, essa presença constitutiva do elemento cotidiano nas lendas urbanas - cotidiano igualmente confortante e ameaçador - ao longo das análises do corpus na Parte II. Mas, antes, resta-me ainda, nesta Parte I, tratar de uma questão que julgo fundamental para entender as práticas discursivas em torno das lendas urbanas. Trata-se da questão da verdade, ou mais precisamente: a vontade de verdade que perpassa o discurso em diversos planos. Dedico, assim, o próximo capítulo a uma investigação mais detida do problema. 


\section{CAPÍTULO 3: A Vontade de Verdade}

"Facts sometimes have a strange and bizarre power that makes their inherent truth seem unbelievable."

- Werner Herzog, "Lessons of Darkness”, 1999

"When weaving a story, how much responsibility rests with the story-teller to shade the truth, and how much with the reader/viewer to differentiate the realities?" (patch, signaling for "once upon a time")

- Pat Chapin, urban-legends@yahoogroups.com, 2005

"Uma silenciosa conivência habita a espessura de uma experiência que um enuncia e outros declaram verídica."

- Michel de Certeau, A Cultura no Plural, 1974

Quando em algum lugar, em algum momento, alguém conta para alguém uma lenda urbana, ou simplesmente se refere a ela, é grande a chance de se ouvirem comentários do tipo: “Mas isso não é verdade, é?”, “Isso não aconteceu, não pode ser verdade”. Ou então, ao contrário, “Juro que isso aconteceu”, “É verdade mesmo, foi fulano que me contou”. De fato, quando se trata de lendas urbanas, é praticamente impossível ignorar a questão da verdade que as cerca. Ela pode estar presente já na própria formulação da narrativa, quando o autor garante que irá contar algo que “realmente aconteceu”, ou pode aparecer nas reações das pessoas que ouvem ou lêem as narrativas, nas formas de incredulidade, dúvida ou mesmo crença imediata. De qualquer maneira, a lenda urbana como gênero é atravessada pela vontade de verdade que está na própria base do conhecimento. De acordo com Foucault (1971/1996; 1975-6/1999; 1979/1996), toda prática discursiva tem a capacidade de gerar efeitos de verdade mais ou menos potentes e duradouros. Tal possibilidade de criação de efeitos de verdade no e pelo discurso se deve a um elemento inescapável aos sujeitos desse discurso: o desejo da verdade.

Por acreditar na centralidade do conceito de verdade nas lendas urbanas, investirei neste capítulo em uma investigação teórica mais detalhada desse conceito, indo buscar, num primeiro momento, subsídios na filosofia de Heidegger e Nietzsche, os quais - em especial o segundo - irão embasar o pensamento de Foucault e teorias de discurso mais recentes. Em seguida, analisarei a questão por um viés mais pragmático, de acordo com uma linha de pensamento que remete a Richard Rorty e, mais 
recentemente, Zygmunt Bauman. Num segundo momento, examinarei mais de perto uma série de mensagens de nosso corpus de análise em que a questão da verdade aparece de maneira explícita - as práticas do grupo de discussão sendo o local de construção de um discurso de verdade -, a fim de ilustrar a reflexão teórica inicial.

\section{A Verdade em Xeque: da Filosofia ao Discurso}

\subsection{A Verdade Ontológica em Heidegger e a Tradição Metafísica}

A problemática da verdade e a busca de sua compreensão se confundem, de certa forma, com a própria história da filosofia ocidental, ou pelo menos com uma longa e estabelecida tradição metafísica de se fazer filosofia. De Platão aos pragmáticos norteamericanos do século XX, dificilmente encontraremos uma corrente ou escola de pensamento filosófico que não tenha, em maior ou menor grau, se debruçado sobre a questão.

Começar a abordar o tema da verdade pela filosofia de Heidegger pode soar, a princípio, como uma tarefa arriscada. Seu pensamento é bastante complexo e, além disso, suas contribuições não parecem ter sido muito exploradas em conexão com os estudos de linguagem e discurso. De qualquer maneira, a partir da investigação de um primeiro Heidegger, o de Ser e Tempo (1927/1995), é possível encontrar conceitos que dialogam bastante de perto com o tipo de discussão que pretendo fazer da problemática da verdade no discurso sobre as lendas urbanas. Portanto, assumo o risco.

Minha proposta é tomar como base o que o filósofo escreve sobre a verdade, especificamente no parágrafo 44 do Primeira Parte daquela obra e no ensaio "Sobre a Essência da Verdade” (1930/1961), e a partir daí “apropriar-me” das idéias que podem de alguma forma iluminar o percurso que aqui começo a desenhar. Obviamente, isso significa “passar ao largo” de toda uma intricada rede de argumentação filosófica, que o autor define como ontologia fundamental alicerçada sobre a questão do Ser, e concentrar-se prioritariamente sobre como verdade e não-verdade ecoam no cotidiano e nas formas concretas - isto é, nas práticas - de ser-no-mundo.

Entretanto, não é possível chegar às idéias que o autor avança sobre a verdade simplesmente desviando-se da questão do Ser, da qual é indissociável. Faz-se necessário 
traçar pelo menos um resumo simplificado da argumentação de Heidegger que irá desembocar no aspecto que julgo mais relevante para meu propósito. E, nessa tarefa, muito me auxiliaram as leituras de comentadores da obra do filósofo, obra essa cuja leitura representa por si só um caminho espinhoso (mas não menos compensador) de entendimento.

Em Ser e Tempo, Heidegger abre sua reflexão propondo o conceito operacional de Dasein (o "ser-aí”) para dar conta de seu projeto de descrever o modo de existência do ser-no-mundo. O Dasein é um construto, uma instância que se projeta, por assim dizer, em direção à compreensão do Ser em sua totalidade ${ }^{16}$. Para Heidegger, a inclinação metafísica de toda uma tradição filosófica que se inicia com o platonismo levou a um gradual esquecimento da especificidade do Ser, em privilégio de uma cisão entre ente e ser e o eventual apagamento deste último. De Platão a Nietzsche, e entre estes Aristóteles, os romanos, Descartes e Kant, todos, à sua maneira, postularam uma forma de metafísica que foi gradualmente construindo o ente como essência, ou única modalidade que baliza a existência e o próprio conceito de verdade - quer num sentido idealista, quer num sentido racional-científico. Vejamos, em brevíssimas pinceladas, como isso se deu.

Platão, o pai de toda a metafísica, lançou a base da tradição que coloca o ser num mundo das idéias, em oposição ao ente vivente concreto. Aristóteles, por sua vez, aparentemente materialista e portanto oposto a Platão, também precisou partir daquela suposta divisão postulada por Platão. Era o período em que a idéia de verdade se estabelecia como a de correspondência às coisas - adequação do olhar ao objeto, ou seja, do modo de ver à natureza das coisas. Na época dos romanos, caracterizada pela ascenção do conceito de império, começava-se a abrir mão do platonismo em privilégio da noção de correção. Ser verdadeiro era ter uma visão correta, justa da realidade. A partir dos modernos, fundamentalmente com Descartes, o ente alçou-se à condição de sujeito cognoscente, ente supremo a partir do qual todo o conhecimento e toda a verdade estavam condicionados. Como sintetiza Marcondes: “A verdade torna-se assim uma relação sujeito-objeto, base de toda nossa concepção de epistemologia, central no pensamento moderno, mas originando-se, de acordo com esta interpretação, já na

\footnotetext{
${ }^{16}$ Para os propósitos da exposição breve que estou traçando aqui, seguirei usando a forma com letra maiúscula quando quiser enfatizar o conceito heideggeriano de Ser em sua totalidade, embora esteja consciente de que a discussão a respeito das diferentes denominações (incluindo o próprio Dasein) pode ser bastante mais técnica.
} 
teoria platônica do conhecimento” (1997/2005: 267). Finalmente, Nietzsche, ao negar categoricamente qualquer essência ao ser - o ente sendo tudo o que restou da metafísica -, desponta como o "último dos metafísicos”, segundo a leitura de Heidegger ${ }^{17}$.

Olhando retrospectivamente para essa tradição, sem no entanto se colocar fora dela, Heidegger irá propor uma espécie de “passo atrás” em direção aos pré-socráticos, com quem se plantou (não por muito tempo) uma compreensão inicial do ser indissociado do ente. Heidegger faz isso não como nostalgia, mas como uma espécie de revelação do “destino abortado” da compreensão do Ser como fundamento da existência - destino esse que a metafísica tratou de obscurecer até sua “máxima potência”, esquecendo-se de que se esqueceu do Ser. Em suma, a metafísica abandonou o ser como há (lampejo, força, revelação) e abraçou o ser como é. Daí o curioso paradoxo: o ente é, mas o ser não é.

Para resgatar o Ser em sua especificidade, isto é, o caráter ontológico da existência, é preciso romper com o sentimento mais imediato que temos de nós mesmos, sentimento esse alicerçado sobre dicotomias do tipo subjetividade e objetividade, mente e mundo, empirismo e idealismo. Como bem define Jonathan Rée (2000: 8), a visão com a qual Heidegger busca romper está embutida na própria alvenaria da filosofia ocidental, ao longo de toda sua história, além de mesclar-se ao próprio tecido de nosso auto-conhecimento cotidiano.

Bem entendido, o homem já nasce com uma certa vocação à ontologia, alternando entre a compreensão que tem de si mesmo como fazendo parte de um universo de coisas que estão prontas-à-mão - isto é, as coisas que só existem porque têm uma função, ou se relacionam com o homem de modo instrumental - e a abertura para um conjunto de questões “mais abstratas” que o acompanham desde sempre, incluindo “O que significa ser?” e “O que é a verdade?”. O que ocorre é que o homem está tão absorvido pela cotidianidade que tende a abstrair as coisas como perdidas numa coletividade impessoal, agindo como um mero ser-entre-as-coisas e se afastando de sua autenticidade.

Quando o homem está imerso nessa cotidianidade, e este é um ponto que nos interessa mais de perto na discussão de nosso tema, ele engaja em atividades

\footnotetext{
${ }^{17}$ Nesse percurso, Heidegger credita a Kant um momento privilegiado do pensamento filosófico, em que a questão da relação ser-tempo, fundamental na teoria do primeiro, pôde ser mais claramente articulada. No entanto, Kant teria ficado a meio-caminho de um desenvolvimento aprofundado da questão, nos termos de Heidegger (ver Boutot 1991: 73-75).
} 
“inautênticas”, como o palavreado, a tagarelice e a curiosidade (e aí incluiria os rumores), que são, segundo Heidegger, formas de “corrupção do discurso”, formas do senso comum de escapar do auto-conhecimento do Dasein. O apego a essas formas reforça a impessoalidade trivial do modo mundano do ser-entre-os-outros. Quando tudo se torna acessível a todos, numa faticidade disforme e indiferente, as coisas-à-mão tornam-se mais e mais instrumentalizadas, o que gera uma opacização na relação estabelecida entre o ente e suas crenças ${ }^{18}$.

Mas voltaremos a essa questão mais adiante quando investigarmos as relações possíveis entre as diferentes visões de verdade e a prática das lendas urbanas. Por enquanto, sigamos buscando entender o que significa, então, para Heidegger, ser autêntico. Ora, não se trata de buscar um Ser essencial, subjetivizado, isolado do mundo e frente a frente com sua própria individualidade. Antes, trata-se de compreender a natureza autenticamente incompleta e fragmentada do Ser em sua totalidade, visto que este é marcado por uma falha constitutiva do próprio estar-no-mundo. Para ser autêntico, o ente precisa se abrir para a liberdade de deixar-ser, deixar as coisas se revelarem como são. Ele precisa se descobrir, paradoxalmente, como irremediavelmente inautêntico, vivendo imerso num universo de coisas prontas-à-mão. A inautenticidade, dessa forma, não é um mero erro ou desvio moral, mas parte integrante da existência autêntica.

É mesmo na abertura à revelação - como descobrimento, desvelamento - que se coloca a questão da verdade ${ }^{19}$. Para Heidegger, a verdade está indissocidada do Ser que a desvela, não sendo esta, portanto, uma propriedade independente das coisas. Toda a verdade é relativa ao Ser do Dasein. A verdade existe necessariamente em função do Dasein, pois à medida em que busca o entendimento de si mesmo, o homem abre caminho para o desvelamento da verdade.

Heidegger ilustra essa proposição tomando como exemplo as leis de Newton. A descoberta de tais leis, segundo o autor, só é possível como resultado da projeção da existência historicamente situada do Dasein, a qual pode nos desvelar um aspecto

\footnotetext{
${ }^{18}$ Comentando o conceito de "mundanidade” de Heidegger, o sociólogo Michel Maffesoli coloca a questão nos seguintes termos: o "ser-aqui” é por constituição paradoxal, "pois o que é próprio do vivenciado, do saber e da experiência enraizada, o próprio da comunidade orgânica, só permite a existência individual em relação ao 'dado': o que é dado pela natureza, pelo grupo (...) O grupo, enquanto limite espacial, permitindo pôr em ordem a experiência individual” (2004/2007: 72).

${ }^{19}$ Heidegger remete ao conceito de aletheia, palavra usada pela tradição mítico-poética dos gregos para se referir à verdade, e que significa precisamente “não-ocultamento”, “desvelamento”.
} 
permanente da natureza como ela realmente é. Em outras palavras, as leis, ao serem descobertas, mostram-se, pelo resultado da abertura à verdade operada pelo Dasein, precisamente como entidades que já existiam antes. É porque ocorre essa abertura que a ciência se encontra ao nosso alcance.

Num primeiro momento dessa discussão, talvez seja difícil ver de que maneira Heidegger se distancia de uma visão idealista de verdade - uma verdade a cujo reino sublime precisamos ascender via consciência transcendente, abrindo mão de nossas peculiaridades individuais, livrando-nos, enfim, de nossa mundanidade ordinária. Mas não é nesses termos que o filósofo coloca a questão. Ao contrário, para Heidegger, a origem e âncora de todo nosso conhecimento é fundamentalmente ontológica, isto é, está atrelada à modalidade do Ser enquanto ser-com, ser-entre outros, ser relacional. A consciência, para o filósofo, não é a de uma essência subjetiva, mas antes a escuta de um lugar possível de autenticidade, um lugar possível de abertura a um desvelamento que, já por constituição, se apresenta como ocultamento em função mesmo do modo de estar-no-mundo inerente ao Ser.

Mas Heidegger irá aprofundar um pouco mais essa problemática da verdade quando fala da não-verdade e da errância como instâncias inseparáveis da verdade, e não simplesmente como seus opostos lógicos. Se, como vimos, a verdade se dá como desvelamento, é porque nasce já como ocultação de sua totalidade. Pelo fato de estarmos todos invariavelmente sujeitos a essa ocultação (ou dissimulação), esta se torna pressuposto e fundamento para o desvelamento mesmo do ser-no-mundo. Ora, Heidegger vem então dizer que esse ocultamento é ele próprio ocultado, uma vez que, inseparável de toda verdade, ele impede que essa última seja concebida como desvelamento total, não chegando nunca a ser reconhecido pelo ser-aí como privação do desvelamento radical. Como resumem Waelhens e Biemel:

“[O] desvelamento é sempre parcial, particular. Ele se dá sobre um fundo de ocultamento que ele ajuda a dissimular por força de seu próprio progresso. Aquilo que se sabe sobre um ente em particular empurra para a sombra o ente em sua totalidade; o próprio sucesso desse desvelamento implica a dissimulação daquilo que é necessariamente oculto.” (Waelhens \& Biemel 1948: 47) 
Tal concepção tem implicações claras para a tentativa do homem de impor-se como medida de todas as coisas, uma vez que é cego para esses esquecimentos. Conforme aponta Ernildo Stein, "na tradição moderna, o sujeito sempre foi medida da verdade. Medida enquanto condição de possibilidade”, e enquanto tal, "o ser humano se apresenta como o padrão para todas as proposições que se referem a situações contingentes onde há verdade e falsidade” (1993: 191). De fato, para Heidegger, é na técnica, no saber moderno da ciência, que se manifesta o apogeu dessa metafísica onde o ente é tomado como a baliza de tudo.

Assim é que o ser ex-istente torna-se in-sistente ${ }^{20}$. O ente erra, e o faz desde sempre, isto é, está condenado à errância. Errância não como o simples erro acidental ou isolado, mas antes "o domínio da história daqueles emaranhados nos quais todos os tipos de erro se entrelaçam” (Heidegger 1930/1961, seção 7). E essa errância e a dissimulação da dissimulação - ou esquecimento, conforme referido anteriormente constituem-se como uma anti-essência do homem, algo que do interior mesmo da essência original da verdade, e a ela pertencendo, a ela se opõe.

De onde se pode concluir que a verdade, em sua origem, se dá sempre-já como não-verdade, não no sentido de oposto lógico à verdade, mas antes no sentido de uma privação, uma incompletude, posto que opera dialeticamente, pela errância do homem histórico, ou seja, pela manifestação da dissimulação/ocultamento de sua totalidade na errância do cotidiano mundano. Conforme resume Stein:

“A verdade originária tem, justamente, este caráter de negação da absolutidade, enquanto nela se dá verdade e não-verdade como contrapontos que se completam. E a não-verdade é introduzida no caráter transcendental da verdade, justamente para não nos perdermos na idéia de que apenas verdade se constitui em fundamento de toda a verdade, de transparência, de apoditicidade, de absolutidade, etc.” (Stein 1993: 190)

Ainda assim, em mais uma demonstração de seu pensamento dialético que visa a eliminar as facilidades de uma lógica binária, Heidegger nos lembra que se o homem conseguir vivenciar essa errância como errância, e não simplesmente se deixar debater

\footnotetext{
${ }^{20}$ Nos termos de Heidegger, ex-istir é estar do lado do ente, "apegar-se" a ele, posto que é o que lhe é mais acessível pela própria cotidianidade.
} 
ou absorver por ela, poderá se orientar - dialeticamente, já que uma coisa funda ou está dentro da outra - em direção à verdade essencial ${ }^{21}$.

Como vimos, Heidegger busca romper com uma tradição metafísicoepistemológica ao resgatar o Ser e a verdade em seu caráter ontológico. No entanto, é preciso que se tenha claro que tal ruptura não se pode dar simplesmente do "exterior" da tradição, como se se pudessem apagar em toda sua extensão, e por uma decisão voluntariosa, os conceitos submetidos à revisão. É o que postula Derrida, ao falar da dupla marca. Para ele, não há sentido abandonar os conceitos da metafísica para abalar a metafísica, uma vez que não possuímos nenhuma linguagem que seja estranha a essa história; "não podemos enunciar nenhuma proposição destruidora que não se tenha já visto obrigada a escorregar para a forma, para a lógica e para as postulações implícitas daquilo mesmo que gostaria de contestar” (1967/2002: 232).

Cada empréstimo específico faz vir a si toda a rede de significações do qual é retirado. Assim é que, embora Heidegger esteja negando a possibilidade de descoberta de uma verdade absoluta, está falando ainda de uma verdade originária. Assim é que, enquanto está falando de verdade e não-verdade como elementos dialeticamente constitutivos dessa essência de verdade, está falando ainda de verdade nos termos de uma presença a si.

Mas, aparentemente, não há como escapar desse “jogo”, para usar o termo derridiano. Derrida, ele mesmo, em seu A Farmácia de Platão elabora a problemática da verdade-como-presença já se apoiando na discussão que Heidegger pôde avançar. Fala da não-verdade, isto é, da desaparição da verdade enquanto presença, como sendo a condição mesma de manifestação da verdade. Em uma relação de suplemento. Diz que a iterabilidade - a possibilidade de repetição, duplicação - é a condição pela qual o entepresente pode ser único, idêntico a si. Mais especificamente: “o verdadeiro e o nãoverdadeiro são espécies de repetição. E só há repetição possível no gráfico da suplementaridade, acrescentando, na falta de uma unidade plena, uma outra unidade que vem supri-la, sendo ao mesmo tempo a mesma o bastante e outra o bastante para substituir acrescentando” (1972/2005: 121). Enfim, Derrida desloca a questão, elabora

\footnotetext{
${ }^{21}$ A propósito, Waelhens e Biemel (1948: 55) apontam que a dialética é uma marca registrada da filosofia de Heidegger. Não se trata, porém, da dialética hegeliana, que busca superar as oposições numa síntese superior. Ao contrário, na dialética heideggeriana, as oposições são definitivamente insuperáveis - o que não significa uma destruição da unidade de seu pensamento. Antes diríamos, como faria Derrida posteriormente (1972/2001a.) , tratar-se de uma “desconstrução”.
} 
sua discussão sobre uma base de termos que ecoa familiarmente a filosofia heideggeriana, mas não necessariamente suplanta essa filosofia ${ }^{22}$.

De qualquer maneira, é possível ir sempre mais além deste horizonte. E nossa investigação prossegue agora apontando como dois outros filósofos importantes (re)elaboram a questão da verdade e de que maneira seu pensamento rompe/dialoga com a tradição.

\subsection{Nietzsche, Foucault e a Verdade como Vontade}

Uma das marcas do pensamento de Nietzsche é a idéia de que não existe verdade enquanto conhecimento do mundo tal como ele é. O filósofo alemão se opunha à idéia de uma possível apreensão da realidade por meio da linguagem, uma vez que não haveria um universo preexistente e delimitado de “coisas a conhecer”. Com efeito, Nietzsche propunha que abandonássemos de vez qualquer tentativa de "conhecimento da verdade”. Para o filósofo, deveríamos abrir mão da idéia de que a linguagem é capaz de recobrir e "representar" o todo da realidade - essa realidade supostamente determinável e cuja verdade nos fosse possível desvelar.

Como se opera, então, o conhecimento? Nietzsche dirá que o conhecimento é uma invenção do homem, ou seja, não é algo que esteja absolutamente inscrito na natureza humana, apenas à espera de uma revelação. Em sua raiz, o conhecimento, antes de surgir como resultado de um impulso em direção a uma identificação, uma afeição ou paixão por seu objeto, é fruto de uma vontade de poder, que "mina” seu objeto e procura aniquilá-lo em toda sua potencialidade ameaçadora. É como se fosse necessário primeiro rechaçar o objeto para logo em seguida trazê-lo de volta ao seu domínio, já domesticado, já moldado. O que implica que toda e qualquer forma de conhecimento, inclusive a ciência e a técnica, torna-se necessariamente perspectiva, parcial, oblíqua.

Ora, se esse conhecimento, fruto de uma vontade histórica, conduz ao que se chama de verdade, esta nada mais é, segundo tal raciocínio, que o resultado de relações humanas contingentes, às quais, por um desejo de verdade, buscamos dar um estatuto universal. A clássica definição de Nietzsche, proposta no ensaio "Sobre a verdade e a mentira no sentido extra-moral”, sintetiza perfeitamente esse pensamento:

\footnotetext{
${ }^{22}$ A reflexão de Derrida sobre a metafísica da presença é, obviamente, muito mais complexa do que posso sugerir aqui. De qualquer maneira, lanço mão especificamente dessa passagem no autor com o intuito de ilustrar um ponto-chave aqui: o de que não há ruptura sem re-inserção, o "novo“ sem a marca do "velho".
} 
"O que é a verdade, portanto? Um batalhão móvel de metáforas, metonímias, antropomorfismos, enfim, uma soma de relações humanas, que foram enfatizadas poética e retoricamente, transpostas, enfeitadas, $e$ que, após longo uso, parecem a um povo sólidas, canônicas e obrigatórias: as verdades são ilusões, das quais se esqueceu que o são, metáforas que se tornaram gastas e sem força sensível, moedas que perderam sua efígie e agora só entram em consideração como metal, não mais como moedas.” (Nietzsche 1873/1987: 34)

A verdade é, então, para Nietzsche, um conhecimento interessado, produto de uma vontade que cria a própria oposição entre o verdadeiro e o falso, ou seja, o efeito de verdade. Ela surge sob a forma de metáforas arbitrárias, as quais vão no entanto se literalizando, assumindo um caráter convencional e naturalizado que se vai transmitir ao longo da história do homem. As metáforas intuitivas de origem são, dessa maneira, tomadas como sendo as coisas elas mesmas.

Mas o homem "se esquece” disso. Ele se esquece de que criou suas próprias verdades, uma vez que se construiu a si próprio e as coisas dentro de um paradigma de racionalidade. Ele acredita partir de uma essência, e que a linguagem serve simplesmente de conduto transparente dessa essência. Acredita, enfim, poder olhar o real pelo lado de fora. E é isso que lhe permite pensar a ciência e a filosofia em termos de descoberta de verdades. Como observa Arrojo, a perspectiva descortinada por Nietzsche nos leva à conclusão de que “o homem não é um descobridor de 'verdades' independentes de seu desejo de poder ou de seu instinto de sobrevivência mas, sim, um produtor de significados e, portanto, de conhecimentos que se consagram através das convenções que disciplinam os homens em grupos sociais” (1992: 54).

A produção de significados sólidos e naturalizados não se dá, entretanto, somente em uma dimensão racional, "um novo mundo regular e rígido como uma praça forte" (Nietzsche 1873/1987: 36); ela se dá também na relação do homem com o mito e a arte. Ele deixa-se enganar pela ilusão de buscar uma forma eternamente nova, matizada, sempre reinventada, de se relacionar com o mundo do sonho. Enquanto isso não lhe causar um dano visível, ele irá se “enfeitiçar” quando ouvir contos épicos sendo contados como verdadeiros, quando vir um ator representar um rei mais regiamente que o próprio 
rei, e, por que não dizer - acrescentando um exemplo aos que Nietzsche propõe -, quando receber e retransmitir lendas urbanas via Internet.

A noção nietzschiana de que a verdade não existe como um dado absoluto e preexistente da realidade, mas que pode existir como efeito - mesmo que necessariamente ilusório - ressalta o caráter utilitário da verdade. Nietzsche acredita na idéia de que o conhecimento, na medida em que se coloca como um conjunto de crenças verdadeiras e confiáveis, pode ser vantajoso para certos propósitos mas não para outros, e que certas coisas podem ser descritas como úteis para certos tipos de pessoas mas não para outros - o que só reforça o abandono do autor da idéia de verdade como correspondência. Isto é, ao invés de corresponder a uma realidade de fatos independentes de sua apreensão por seres humanos, a verdade é proposta por Nietzsche como sendo um modo de satisfazer desejos, necessidades e incertezas humanas.

Esse tipo de pensamento permite aproximá-lo de uma visão mais pragmatista da realidade - visão essa que exploro na seção seguinte. Mas é aí também que parece estar a fonte de uma aparente contradição no projeto filosófico de Nietzsche, pelo menos tal como ela é apontada por aqueles comentadores de sua obra que buscam reconciliar, de um lado, a negação de qualquer aspiração metafísica à verdade, explicitamente demarcada em suas primeiras obras, e, de outro, o investimento em "verdades”, elas mesmas de vocação metafísica, como o eterno retorno e a vontade de potência, presentes em sua obra mais tardia ${ }^{23}$. A questão se coloca, para esses comentadores, nos termos de uma “auto-refutação”. Quer dizer, estaria Nietzsche negando a si próprio, em seus próprios termos, ao propor verdades metafísicas quando essas não poderiam, já de princípio, sequer existir? Tratar-se-ia mesmo de um paradoxo irreconciliável?

Ora, a resposta a essas questões não parece tão complicada assim quando, mais uma vez em nosso auxílio, Derrida (1972/2001b.) dirá que a metafísica está tão intimamente circunscrita à linguagem que não pode ser atacada sem que usemos seus próprios conceitos para tal. É precisamente pela contradição e aparente auto-refutação que Nietzsche desenvolve seu pensamento. Pois, ao propor seus insights filosóficos, ele não está necessariamente clamando por verdades universais. A idéia de uma verdade última e transcendental não deixa necessariamente de ser combatida quando se postula, por exemplo, que toda a verdade é função de um desejo de potência humano,

\footnotetext{
${ }^{23}$ Para um levantamento das diversas vertentes interpretativas do pensamento nietzschiano a respeito da verdade, vale consultar Clark (1990/1998).
} 
demasiadamente humano. Quando o faz, Nietzsche não está em contradição com sua anti-metafísica. Ao contrário, está exercendo na prática outro de seus insights filosóficos importantes: o de que todo conhecimento - e, conseqüentemente, toda verdade - é necessariamente perspectivo, tornando-se impossível qualquer pretensão a uma apreensão absoluta e definitiva da realidade. Como bem sintetiza Mosé, “[a]o afirmar que a verdade é um valor, Nietzsche busca dessacralizar esse princípio de avaliação, desvela[ndo] sua condição de invenção humana: a verdade é uma idéia, uma construção do pensamento, ela tem história” (2005: 31). É, portanto, inescapavelmente parcial.

Pode-se ainda “defender” Nietzsche contra a acusação de contradição evocando o caráter afirmativo de seu projeto, isto é, seu posicionamento no sentido de afirmar a vida. Segundo o filósofo, para que sigamos vivendo, precisamos conservar certas categorias classificatórias (e que a linguagem consolida), não porque estas correspondam à natureza das coisas, mas simplesmente porque nos dão a ilusão necessária do conhecimento. Nietzsche apóia-se na idéia de que as coisas existem como um fluxo, o qual a linguagem desmembra para fins utilitários e práticos; mas tal desmembramento não necessariamente avança nossa compreensão das coisas, apenas nos "facilita a vida”, dando-nos uma ilusão de compreensão (Blackburn 2006: 169). Assim é que podem-se interpretar as “verdades universais” da vontade de potência e do eterno retorno, por exemplo, não como um resgate (contraditório ou auto-refutativo) da metafísica, mas antes como a proposição para uma "retomada do caráter criativo, que ocorreria com a explicitação do caráter metafórico das palavras e da verdade” (Mosé 2005: 85), ou, em outros termos, a proposição para uma tomada de “' atitudes em relação à vida' que nos ajudam a vivê-la da forma mais afirmativa possível” (Olson 2001: s/p).

Por fim, mantendo uma relação de coerência com o perspectivismo de Nietzsche, diríamos que suas idéias podem, de fato, soar contraditórias, mas isso só é possível dizer a partir de um certo ponto de vista - certamente um ponto de vista que não busca no próprio projeto nietzschiano uma “verdade universal”.

Outro importante filósofo enxerga as contradições no pensamento nietzschiano como vitais, e não auto-refutativas. Refiro-me a Foucault. Influenciado diretamente por Nietzsche, o filósofo francês irá buscar aí boa parte da fundamentação de um dos pilares de seu pensamento: a relação de interdependência entre poder e saber. Mas antes vejamos como essa interdependência está vinculada à visão de verdade deste autor. 
De acordo com Foucault (1971/1996: 13-21), a verdade é um importante procedimento de exclusão externo da ordem do discurso ${ }^{24}$, que opera por meio da oposição verdadeiro/falso. Quando se trata de olhar para o interior de um discurso, no nível de uma frase ou proposição, tal oposição não se apresenta como arbitrária, nem violenta. Também não se modifica: a proposição é sempre verdadeira ou sempre falsa. Mas quando se trata de identificar qual tem sido, historicamente, a vontade de verdade que atravessa nossos discursos e que espécie de separação a rege, então a verdade se configura como um sistema de exclusão histórico e institucionalmente sustentado. Grandes mutações por que nossas sociedades passaram ao longo de séculos, incluindo descobertas científicas, podem ser lidas, em grande medida, como resultado de sempre novas vontades de verdade que foram se impondo em um conjunto de práticas institucionais como a pedagogia, a pesquisa empírica, ou a exploração de recursos tecnológicos.

Mas algo muito particular ocorre com o discurso verdadeiro: por se apresentar como liberto do desejo e do poder, ele não pode reconhecer a vontade de verdade que o atravessa; isto é, para se impor como verdadeiro, o discurso não pode deixar de se mascarar como produto dessa vontade. Assim, o que nos é dado a ver é "uma verdade que seria riqueza, fecundidade, força doce e insidiosamente universal” e não a “prodigiosa maquinaria destinada a excluir todos aqueles que, ponto por ponto, em, nossa história, procuraram contornar essa vontade de verdade e recolocá-la em questão contra a verdade” (Foucault 1971/1996: 20).

Pode-se já perceber como a verdade não se produz como um organismo autônomo, livre de equívoco, pairando sobre a errância humana e independente dos mecanismos institucionais de ação e controle sociais ou da vontade humana. A verdade está, definitivamente, atrelada a esses mecanismos, e, portanto, ao poder. Foucault nos lembra que em qualquer sociedade as múltiplas relações de poder que caracterizam o corpo social não podem se estabelecer nem funcionar sem um regime de verdade, isto é, sem que sejam sustentadas por discursos verdadeiros. Nas palavras do autor:

“Não há exercício do poder sem uma certa economia dos discursos de verdade que funcionam nesse poder, a partir e através dele. Somos submetidos pelo poder à produção da verdade e só podemos exercer o

\footnotetext{
${ }^{24}$ Para uma discussão dos demais procedimentos de exclusão, ver Capítulo 1, seção 2.
} 
poder mediante a produção da verdade. (...) Afinal de contas, somos julgados, condenados, classificados, obrigados a tarefas, destinados a uma certa maneira de viver ou a uma certa maneira de morrer, em função de discursos verdadeiros, que trazem consigo efeitos específicos de poder, efeitos de verdade." (Foucault 1975-6/1999: 28-9)

Dessa forma, Foucault conclui que o desejo da verdade, originário da divisão historicamente construída entre certo e errado, ou verdadeiro e falso, nada mais é do que o desejo excluidor do poder. O discurso "verdadeiro" não passa de uma ilusão necessária para que os sujeitos lutem pelo poder. E é importante entender como essa luta se dá no interior mesmo da prática discursiva: não podemos enxergar "a” verdade pois sempre-já nos alocamos a uma posição de sujeito circunstanciado ao enunciarmos o que quer que seja.

O autor propõe que, para analisar a vontade de poder (e saber) no discurso, é preciso construir e definir, pouco a pouco, os instrumentos de análise, em uma atividade que ele chama de "genealógica”. Isso se faz de acordo com exigências e possibilidades delineadas por estudos concretos, localizados (Resumo do Curso de 1970-1, in: Foucault 1997). Trazendo para essa perspectiva nosso objeto de estudo, acredito que é preciso investigar e entender melhor como as práticas discursivas ao redor das lendas urbanas freqüentemente salientam a questão da veracidade versus falsidade das histórias como sendo $a$ razão de ser das lendas - como se essas dependessem exclusivamente de um veredicto "objetivo-científico" para se sustentar. Trata-se, com efeito, de uma investigação que passa pela análise das práticas discursivas na sua dimensão de saberes locais. Conforme sustenta Foucault:

“... não se trata de forma alguma de opor à unidade abstrata da teoria a multiplicidade concreta dos fatos: não se trata de forma alguma de desqualificar o especulativo para lhe opor, na forma de um cientificismo qualquer, o rigor dos conhecimentos bem estabelecidos. (...) Trata-se, na verdade, de fazer que intervenham saberes locais, descontínuos, desqualificados, não legitimados, contra a instância teórica unitária que pretenderia filtrá-los, hierarquizá-los, ordená-los em nome de um 
conhecimento verdadeiro, em nome dos direitos de uma ciência que seria possuída por alguns.” (Foucault 1975-1976/1999: 13)

Como veremos em mais detalhes adiante, um grande número de mensagens da lista de discussão que compõem o corpus deste trabalho gira especificamente sobre a questão da verdade das/nas/ao redor das lendas. É freqüente observar como os diversos interlocutores lutam, por meio de argumentos e referências científicas supostamente legitimadas, para desbancar os rumores ou "proto-lendas" e re-estabelecer a ordem dos fatos, tão logo estes cheguem a suas caixas de correio eletrônico. Certamente, será preciso olhar com atenção para o modo como esses textos elaboram a tensão entre aqueles saberes locais, descontínuos e não verificados que circundam as lendas urbanas e a força hierarquizante de um conhecimento verdadeiro, um conhecimento que, disponível a todos por meio de um aparato lógico-racional da ciência, é como que "revelado" ou "esclarecido" pelo discurso desses alguns que o detêm.

Mas, nessa altura, convém não perder de vista a ressalva de Foucault de que não ocorre uma mera divisão entre discurso admitido e discurso excluído, ou entre discurso dominante e discurso dominado. Quer dizer, "[n]ão existe um discurso do poder de um lado e, em face dele, um outro contraposto" (1976/1999: 96-97). Antes, numa dada prática discursiva, costuma-se verificar uma co-relação de forças, uma multiplicidade de estratégias de poder/saber diferentes que coexistem. E é essa distribuição de forças que nos cabe detectar na análise: o jogo entre as coisas ditas e as não-ditas ou interditas; as variantes e efeitos distintos segundo quem fala, quando, de que posição de poder, e dentro de que contexto institucional; os deslocamentos e reutilizações de formas idênticas para objetivos opostos.

Enfim, é preciso admitir a existência de "um jogo complexo e instável em que o discurso pode ser ao mesmo tempo, instrumento e efeito de poder, e também obstáculo, escora, ponto de resistência e ponto de partida de uma estratégia oposta” (op. cit.: 96). Isso nos permitirá explicar o fato de poder haver discursos distintos e mesmo contraditórios dentro de uma mesma estratégia, ou ainda discursos que circulam sem mudar de forma em meio a estratégias opostas. 


\subsection{Rorty e a Visão Pragmatista de Verdade}

Finalmente, vejamos o que pensa a linha filosófica pragmatista a respeito da verdade. Os pragmatistas são filósofos de uma tradição majoritariamente anglo-saxônica para quem o saber é uma ferramenta, um instrumento que deve ser posto a serviço das condições da experiência. Um dos princípios básicos do pragmatismo - comum ao pensamento de seus maiores representantes, de William James a Richard Rorty, passando por John Dewey e Donald Davidson - é o anti-representacionismo: a idéia de que não existe um mundo "lá fora”, uma realidade independente do pensamento que possa ser representada pela linguagem em uma relação de adequação ou correspondência. Uma idéia que, conforme apontamos, já estava presente em Nietzsche.

O mesmo se dá com a noção de verdade, que, já nos primeiros pragmatistas, aparece como desvinculada da idéia de representação das coisas da realidade. O foco passa a incidir sobre a experiência, no modo como as pessoas se relacionam com a realidade. Segundo essa linha de pensamento, a verdade não pode ser uma correspondência com a realidade, mas antes, o produto contingente de relações que os humanos estabelecem entre si por meio de usos, ou, nos termos de Wittgenstein, "jogos de linguagem”. Em outras palavras, o “verdadeiro” não é uma propriedade externa à linguagem, um predicado das coisas do mundo "lá fora”, mas sim um expediente fundamentalmente lingüístico, um predicado de frases, sentenças ou proposições.

Richard Rorty, talvez o nome mais expoente do pensamento pragmatista da atualidade, formula a questão nos seguintes termos:

“Dizer que a verdade não está diante de nós é simplesmente dizer que onde não há frases não há verdade, que as frases são elementos das linguagens humanas e que as linguagens humanas são criações do homem. A verdade não pode estar diante de nós - não pode existir independentemente da mente humana - porque as frases não podem existir dessa maneira ou estar diante de nós dessa maneira. O mundo está diante de nós, mas as descrições do mundo não. Só as descrições do mundo podem ser verdadeiras ou falsas; o mundo por si próprio - sem auxílio das atividades descritivas dos seres humanos - não pode.” (Rorty 1989/1994: 25) 
Tal reflexão leva Rorty a questionar mesmo se a verdade ainda se presta à investigação filosófica como um conceito relevante e inquestionável em si mesmo. Ele se pergunta sobre a utilidade para a sociedade humana de se insistir em compor uma teoria sobre a verdade, um corpo de pensamento consistente que dê conta de um conceito que, afinal, atravessa toda a problemática epistemológica-metafísica-transcendental, de Platão a Heidegger, e continua a confundir e obscurecer o pensamento filosófico - inclusive daqueles que ele considera seus precursores, como James e Dewey. Antes, segundo Rorty, o pensamento filosófico deveria se voltar para a descrição das condições nas quais o "verdadeiro” se apresenta em comportamentos lingüísticos, isto é, em práticas contingentes nas quais as pessoas fazem coisas com a linguagem ${ }^{25}$.

A visão de verdade que Rorty, ele próprio, procura desenvolver vai na direção de reter o que há de minimalista - leia-se: o caráter descritivo, não explicativo, dos usos da linguagem - nas teorias semânticas e comunicativas propostas por seus antecessores, e abandonar o que nelas ainda possa haver de resquícios metafísicos ou representacionistas. Em sua leitura de Davidson, por exemplo, ele valoriza a proposta de trabalhar com hipóteses empíricas - como o faz um lingüista de campo - para dar conta de comportamentos complexos que determinados falantes adotam em determinados conjuntos de enunciados, os quais poderiam ser formalizados e sistematizados tal como semanticistas (entre os quais, Ramsey e Tarski) se propuseram anteriormente a fazer a partir de noções como “condições de satisfação”. Sem entrar em pormenores que nos desviariam consideravelmente de nosso objetivo aqui, cabe ressaltar que o que Rorty valoriza antes de mais nada na tradição em que se insere é a vocação de seus precursores - resguardadas as diferenças e divergências - para deslocarem o foco sobre questões tais como “O que no mundo é verdadeiro?” para questões do tipo “Como se usa o termo ‘verdadeiro’?” (Rorty 1991/1999: 132), ou para, basicamente, considerarem a questão da verdade na linguagem em termos performativos, evidenciando a natureza necessariamente pública e portanto social da linguagem.

Assim é que, ao invés de empreender uma teoria sobre a verdade, Rorty propõe

\footnotetext{
${ }^{25}$ Rorty se inspira na idéia wittgensteiniana de que a prática filosófica atual deveria assumir uma função "terapêutica", pela qual, antes de alimentar e tentar resolver pseudoproblemas metafísicos - entre eles, notadamente, a questão da verdade - , a filosofia deveria buscar dissolvê-los, intervindo somente quando se deseja "diagnosticar e tratar algum desconforto filosófico" (Ghiraldelli 2001: 112). Trata-se, para Rorty, de criar vocabulários novos para abordar problemas antigos de modo realmente original.
} 
identificar os usos lingüísticos dos termos “verdade” e “verdadeiro”, estabelecendo a seguinte tipologia (op. cit.: 128):

1) Uso de endosso: aquele em que os falantes avaliam explicitamente sua fala como sendo verdadeira, ou como expressando aquilo que consideram verdadeiro - em expressões como “é claro que”, “é verdade”, “certamente”, “sem dúvida que”, etc.

2) Uso descitacional: em que se deixa claro que aquilo que os outros dizem não é necessariamente endossado pelos falantes. Trata-se de reconhecer a voz do outro, mas colocando-a, por assim dizer, “entre aspas”.

3) Uso preventivo: o que lança mão da distinção entre verdade e justificação - algo pode ser justificável (por exemplo, "um governo não tem o direito de roubar o dinheiro do povo”), mas não verdadeiro. Para Rorty, não se trata aqui de uma diferença de graus entre uma verdade “mais profunda”, ou “escondida”, e uma outra “aparente” e “superficial”. Trata-se mesmo de uma equivalência: a verdade existe enquanto justificável, embora, é claro, a justificativa possa sempre ser uma outra, ou várias outras, dependendo do momento histórico, do local de enunciação, dos enunciadores, etc.

Tal tipologia permite a Rorty tornar mais explícita a visão contingente e contextualista que ele tem sobre a verdade. Numa espécie de minimalismo radical, o que Rorty está nos dizendo é que "tudo o que se pode dizer de X é o que X é”, sendo que não há para X um lado oculto ou “intrínseco” que escape à apreensão relacional que se faz de X pela linguagem. Como aponta Ghiraldelli, para Rorty a verdade não pode ser descoberta. "Isto seria admitir que a verdade depende 'de como o mundo é' (...) no sentido em que tal expressão engloba apenas relações causais e não as descrições pelas quais não podemos conversar sobre tudo, inclusive falar de relações causais $e$ descrevê-las” (2001: 118).

Estendendo essa sua visão para uma formulação mais especificamente política, Rorty defende que, em uma sociedade idealmente liberal e democrática, a idéia de verdade enquanto correspondência com a realidade deveria ceder lugar a uma idéia de verdade como aquilo que se passa a crer ao longo de encontros livres e abertos. Nos dizeres do autor: 
"[U]ma sociedade liberal é uma sociedade que se contenta com chamar 'verdadeiro' (ou 'certo' ou 'justo') ao resultado, seja ele qual for, de uma comunicação não distorcida, a uma perspectiva, seja ela qual for, que vença num encontro livre e aberto. Essa substituição equivale a pôr de parte a imagem de uma harmonia preestabelecida entre o sujeito humano e o objeto do conhecimento e, assim, a pôr de parte a problemática epistemológica-metafísica-transcendental.” (Rorty 1989/1994: 98)

Para Rorty, então, a verdade surge como uma contingência histórica, e não como uma convergência, ou consenso comunicativo, racional e válido universalmente, conforme defendem figuras como Jürgen Habermas (Rorty 1989/2004; Ghiraldelli 2001). Mas isso significa que se deva interpretar a visão de Rorty como reduzindo a verdade a um mero pacto, um acordo frágil sujeito aos caprichos dos “jogadores de linguagem”?

Vejamos, por exemplo, o que Zygmunt Bauman tem a dizer nessa conexão. Embora se alinhe à visão pragmatista pela qual a verdade, antes de simbolizar a relação entre o que é dito e determinada realidade não-verbal, "simboliza nos nossos usos uma determinada atitude que adotamos, mas acima de tudo desejamos e esperamos que outros adotem, para com o que é dito ou acreditado", (1998: 142) o sociólogo polonês insiste em salientar que, em determinadas crenças, o que está em questão é algo mais do que o uso da verdade como endosso, algo que vai além da mera aprovação. Está em questão o modo como essas crenças atingem tal grau de certeza e confiança que qualquer ponto de vista alternativo ou contrário seja rejeitado.

De acordo com Bauman, não há sentido em falar de verdade se não em uma situação de desacordo. Isto é, a verdade só surge como questão quando diferentes pessoas se apegam a diferentes crenças, tornando-a objeto da disputa sobre "quem está certo e quem está errado". Ela surge quando se reivindica o direito de alguém falar com autoridade, e quando torna-se particularmente importante a um adversário comprovar que o outro lado da disputa está errado. A disputa pela verdade representa, dessa forma, a luta pelo estabelecimento de determinadas espécies de crenças como sistematicamente superiores, "sob o pretexto de que a elas se chegou graças a um determinado procedimento confiável, ou que é assegurado pela espécie de pessoas em que se pode confiar que o sigam” (Bauman 1998: 143). 
O que Rorty faria, até onde o interpreto, é colocar essa questão em outros termos, talvez menos “ideológicos”. Ao discorrer sobre a relação entre verdade e justificação - lembremos que tal relação corresponde ao item 3 de sua tipologia de usos resumida anteriormente, o do uso preventivo -, o filósofo sustenta que a necessidade de justificar nossas crenças e desejos aos outros e a nós mesmos nos submete a normas, a obediência às quais "produz um padrão de comportamento que temos de detectar nos outros antes de, com confiança, atribuir-lhes crenças” (1998/2005: 13-4). Ou seja, entramos no jogo de linguagem com determinadas crenças, e sabemos que os outros com quem jogamos possuem, de seu lado, suas próprias crenças. Mas há que se comprovar a existência dessas crenças performativamente, no interior de trocas lingüísticas, e não assumi-las como dadas de antemão. O que Rorty não acredita, talvez diferentemente de Bauman, é que essas normas do jogo lingüístico visem necessariamente a obedecer a uma "ordem adicional: o comando para buscar a verdade” (Rorty 1998/2005: 14).

O que Bauman estaria então fazendo em sua argumentação se não reacender a chama da idéia de vontade de verdade, associada à vontade de poder, identificada por Nietzsche e Foucault? E para não fugir à terminologia do próprio Rorty, o que seriam aquelas crenças “certas e confiáveis”, para cuja força adverte Bauman, se não metáforas que, contingentes em sua origem, vão aos poucos se literalizando?

Para além das diferenças irreconciliáveis entre uma e outra teoria sobre verdade aqui discutida, acredito ser possível encontrar em todas elas pontos de apoio e referência para a discussão que me interessa percorrer aqui, a saber: por que a verdade é uma questão tão central no discurso das e a respeito das lendas urbanas? Talvez a perspectiva que eu esteja adotando sobre a teoria se aproxime do da reflexão pragmatista, para a qual o conhecimento é tão bom quanto se possa fazer dele uma aplicação utilitária. Segundo esse ponto de vista, é possível dizer que Heidegger, Nietzsche, Foucault e Rorty se complementam - não de uma maneira continuista, como numa linha de progressão de pensamento de um teórico para outro, mas antes como a intersecção de determinados pontos em comum a respeito da verdade.

Se olharmos retrospectivamente para o que foi discutido, veremos como todos esses filósofos propõem uma ruptura com a noção de verdade como correspondência absoluta entre o mundo e sua representação, entre as palavras e as coisas. Veremos 
também como a questão da verdade é inseparável de uma reflexão sobre as práticas (humanas) do cotidiano, em que pessoas fazem coisas com a linguagem. Ora, essas práticas podem ser vistas, como por Heidegger, como errância, ou como por Nietzsche, como uma ilusão. Podem ainda ser vistas como por Foucault, como práticas de luta e resistência em um regime de verdade que mobiliza saberes e engendra poderes. Ou, finalmente, como defende Rorty, elas podem ser vistas como uma abertura para a criação e consolidação de crenças contingentes, resultantes de encontros livres e abertos. Mas todos irão concordar que tais práticas são necessárias, no sentido de que constituem o modo de existir do homem no mundo.

Assim, errar, segundo Heidegger, é estar imerso em um universo em que as coisas do mundo, as coisas que estão à mão e, portanto, apreendidas em função de sua relação com o homem, se tornam instrumentalizáveis. Sim, claro, Heidegger vê aí o modo do próprio ente operar em seu esquecimento do Ser. Mas é justamente essa imersão na cotidianidade que nos interessa aqui, mais do que uma suposta "essência esquecida”.

Em Nietzsche, por sua vez, é a ilusão de domar a realidade por meio da linguagem - uma linguagem que já nasce metafórica mas que sufoca, por meio do esquecimento, a movência dessas metáforas, tornando-as mortas - que permite que o homem sobreviva em sua ilusão de identidade, de racionalidade, enfim, em suas “verdades duráveis”.

Nessa mesma esteira, Foucault dirá que as práticas discursivas tendem à rarefação dos discursos: na proporção mesma em que os discursos se proliferam, eles se submetem a um regime de verdade que os restringe, limitando seu acaso e, portanto, rarefazendo-os. Isto é, os discursos se afirmam como verdadeiros, mas só o fazem dentro de uma ordem (prática) que estimula sua proliferação ao mesmo tempo em que freia sua expansão, num mecanismo próprio e necessário à correlação de forças de poder e saber.

Já Rorty, ao dessacralizar a idéia de verdade como algo a ser revelado, algo que seria intrínseco as coisas, aposta suas fichas nas coisas que seres humanos fazem com a linguagem, no uso contingente dos vocabulários, que só podem se afirmar como verdades em decorrência de práticas e usos historicamente situados. 


\section{A Verdade nas Lendas Urbanas}

No horizonte das reflexões sobre a verdade traçadas anteriormente, proponho olhar mais de perto, nesta seção, para um subconjunto de textos do nosso corpus composto por mensagens trocadas entre os membros da lista de discussão (www.snopes.com) durante o período de 1 a 21 de setembro de 2005, logo na seqüência da passagem do furacão Katrina pela costa leste dos Estados Unidos. Entre boatos, lendas, comentários e testemunhos, o site foi mais um dos inúmeros fóruns em que o fenômeno foi discutido e interpretado. Minhas interpretações vêm se juntar aos inúmeros fios de interpretação que ainda (e sempre) estão se tecendo sobre os fatos. Trata-se de um gesto de escrita sobre o Katrina, ou, talvez seria melhor dizer, sobre discursos que se mobilizam, contradizem, contradistinguem, reforçam ou perpetuam efeitos de verdade sobre realidades tais como um furacão devastador.

\subsection{No Rastro do Furacão: construindo um discurso de verdade}

Cada vez que um fenômeno natural de proporções gigantescas se abate sobre o planeta, como nos casos mais recentes do tsunami na Ásia no final de 2004 e do furacão Katrina nos Estados Unidos em meados de 2005, reaparecem discursos premonitórios, vexatórios e punitivos buscando dar conta dos fenômenos.

Em um primeiro momento, tem-se a percepção generalizada de que as estruturas foram abaladas, uma vez que não se pode assimilar, logo de início, tamanha devastação. Mas logo o efeito sempre-já-lá da estrutura trata de atribuir agência ao outro, esse outro que assume diversas formas. Em um nível de significação, é o Deus que pune e se volta com sua ira aos abusos do homem; a própria natureza, com sua autonomia, que se revolta; ou ainda Deus e natureza agindo como a extensão suplementar um do outro. Em um outro nível de significação, são os presidentes dos países afetados pelas tragédias, acusados de negligência e demora no envio de ajuda; ou as autoridades locais que empurram entre si as responsabilidades; ou esse outro não-negro que age racistamente em prejuízo das comunidades negras vítimas diretas da catástrofe (caso de grande parte da população de Nova Orleans, nos Estados Unidos, devastada pelo Katrina). Os argumentos e as explicações vão assim se sucedendo e sobrepondo na tentativa de estabelecimento de uma "verdade" em meio a um acontecimento em grande 
parte imponderável. Sim, há fatos verificáveis como o de os diques de Nova Orleans terem sido projetados de maneira a não sustentar fenômenos como um furacão. Mas há também fatos que remetem mais explicitamente a lutas de poder, a esquemas de saber/poder tão bem engendrados que tornam e tornam a aparecer como que carregados pela própria ventania. O motivo do racismo é somente um deles.

A mensagem que inaugura nosso conjunto, enviada à lista nas primeiras horas do dia $1^{\circ}$ de setembro de 2005, já se apresenta como polêmica. Nela, Sarah Hall reproduz a mensagem de um suposto médico que escreve, via Internet, diretamente do Hotel Ritz Carlton em New Orleans (A Physician writes from New Orleans) dando um testemunho panorâmico da situação do local. Com descrições bastante detalhadas ${ }^{26}$, o autor aborda a situação das populações desabrigadas, os riscos de saúde que enfrentam, as dificuldades das ações de resgate, bem como o problema dos saques a lojas e supermercados em busca de alimentos e produtos de primeira necessidade. Segue-se então, dentro de um espaço de pouco mais de 24 horas, uma série de quatro respostas questionando a veracidade do relato, apontando desde erros de ortografia na mensagem, a ausência de sentido de certas palavras - o autor refere-se a uma HIV confection que estaria ocorrendo no hotel, o que gera confusão entre os respondentes: seria uma $H I V$ convention? -, até informações duvidosas: haveria mesmo um risco aumentado de cólera na região? Ao que um respondente contesta com informações ouvidas de um especialista em saúde pública na rede de TV CNN. Como efeito geral, coloca-se o relato, se não como desqualificado por completo, pelo menos sob forte suspeita.

Mas talvez o aspecto mais curioso a se destacar aqui é como o teor testemunhal da mensagem do suposto médico, um documento aparente de legitimidade por se tratar de alguém que escreve diretamente de um local privilegiado (do centro do furacão, por assim dizer), acaba derrotado em seus próprios termos, na medida em que, como apontam seus respondentes, suas informações parecem plagiadas de fontes jornalísticas aqui e acolá. Um desses respondentes chega ao curioso veredicto: "While I have no doubt that the conditions in New Orleans and surrounding areas are indeed horrific, this particular email forwards [sic] strikes me as something cobbled together by some well-intentioned idiot from half-heard news reports" ${ }^{27}$. Poderíamos afirmar que está se

\footnotetext{
${ }^{26}$ Ver APÊNDICE A para o texto original completo.

${ }^{27}$ Para fins de análise, opto por manter no original a maior parte das citações a partir das mensagens do corpus, aqui e em toda a Parte II.
} 
condenando aqui à “falsidade” uma narrativa - um acontecimento enunciativo justamente por ela deixar entrever sua composição intertextual, ou melhor, por deixar-se mostrar, sob sua estrutura claudicante, enquanto gênero heterogêneo: afinal, se se trata de um testemunho ocular, não deveria conter trechos simplesmente "bricolados" de fontes reconhecíveis numa memória, ainda que recentíssima, de discursos veiculados sobre a tragédia. Fatos, enfim, nem mesmo fatos tão circunstanciados, são suficientes para garantir a "legitimidade" de um relato, sua justeza enquanto suposta correspondência à realidade. Num regime de verdade em que a memória aberta de fontes intertextuais recentes lança dúvidas sobre a autenticidade de um testemunho, os fatos paradoxalmente derrubam o edifício sólido da narrativa!

Caso um tanto diferente é o de um blog post publicado no jornal eletrônico The Huffington Post e reproduzido numa mensagem enviada à lista no dia seguinte. De autoria de Randall Robinson, ativista negro descrito como um "social justice advocate and author", o texto toma como ponto de partida um rumor segundo o qual negros vítimas do furacão em Nova Orleans teriam começado a praticar canibalismo para sobreviver. A partir daí, em um tom de franca desesperança, Robinson comenta o estado lastimável a que os Estados Unidos haviam chegado naquele momento. Para o ativista, o episódio de Nova Orleans marca o fim da América pela qual ele sempre lutou: “This is what we have come to. This defining watershed moment in America's racial history (...) I am hopeless. I am sad. I am angry against my country for doing nothing when it mattered”. E conclui, escrevendo "com as mãos trêmulas de raiva”, que agora ele vê o país como ele realmente é, “a monstrous fraud”, e que se está vivendo "the lowest moment in my country's history”. É assim que, acredita, milhões de negros como ele devam estar se sentindo. Pois bem, a mensagem está transmitida, ainda que acompanhada, na seqüência de sua publicação, de uma retratação na qual o autor reconhece que a premissa de seu texto estava incorreta, que tudo lhe havia sido contado mas que os rumores provaram ser "unsubstantiated" 28.

O ativista se retrata, portanto, mas não retira uma palavra do que escreveu no restante do texto, o qual mantém sem reserva. Certamente para a comunidade cativa de leitores de Robinson, um rumor retratado não mancha de modo algum aquilo que se constrói como o elemento verdadeiramente "substancial” de sua escrita: o discurso da

\footnotetext{
${ }^{28}$ Ver APÊNDICE A para o texto original completo.
} 
discriminação, da vitimização e da revolta contra um governo que demorou tanto para agir. Se há questionamento ao texto de Robinson, ele aparece um tanto previsível, sob a forma de leitores que ora reprovam seu "ódio inútil” (“Your hate helps nobody”, diz um), ora se solidarizam sob o "impacto verdadeiro" de sua mensagem - ao qual nem mesmo alguém que se afirma como um w.a.s.p. (branco, anglo-saxão, protestante) fica indiferente: " $\mathrm{i}$ am a w.a.s.p. but if i could reach across the internet, i'd love to give you a big hug and shake your hand...”. Verdades, portanto, se edificam a partir de rumores. E estruturas são reforçadas em pleno olho de um furação. Retomando Heidegger, poderse-ia dizer que os seres aqui insistem em sua errância, atendo-se àquelas categorias culturais e históricas com que conseguem (ou "teimam”) enxergar eventos que se lhes apresentam como insuportavelmente contingentes. Já de acordo com a visão pragmatista nos moldes da de Rorty, o discurso de Randall Robinson, antes de ser apontado como “falso”, poderia ser descrito em termos de uma prática de justificação. Isto é, a mensagem de desagravo justifica a eventual “imprecisão dos fatos”. O que não significa, evidentemente, que esse discurso seja mais ou menos verdadeiro, mais ou menos "próximo do real”, que o do suposto médico que escreve do Ritz Carlton Hotel.

Nesse mesmo dia 2 de setembro, o site Snopes enviou aos membros do grupo de discussão a ele associado seu boletim semanal com as mais recentes notícias e atualizações. Na seção dedicada ao furacão Katrina, uma nova polêmica. Duas fotos, (vide abaixo) feitas por duas agências diferentes, a Associated Press (AP) e a Agence France-Presse (AFP), e distribuídas por diversas outras fontes de notícias na Internet incluindo a Yahoo! News - levantam a questão: houve racismo na descrição da primeira como a de um homem negro tendo saqueado (“looting”), enquanto que na segunda um casal branco teria apenas encontrado (“finding”), os suprimentos provenientes de um mercado local que levavam consigo quando tentavam andar em plena enchente, com água à altura do peito?

O texto da Snopes tenta responder essa questão ponderando sobre a dificuldade de se tirar conclusões definitivas a partir das legendas das fotos. Levantam-se várias hipóteses para a aparente diferença de tratamento nos dois casos, dentre as quais: a possibilidade de as duas agências terem padrões estilísticos diferentes quanto à escolha exata das palavras que utilizam, ou a tentativa de se evitar vocabulário repetitivo outras fotos teriam usado outros termos em suas legendas, incluindo "raiding," (invadindo), "taking" (levando) e "making off " (fugindo com/roubando) -, ou mesmo a 


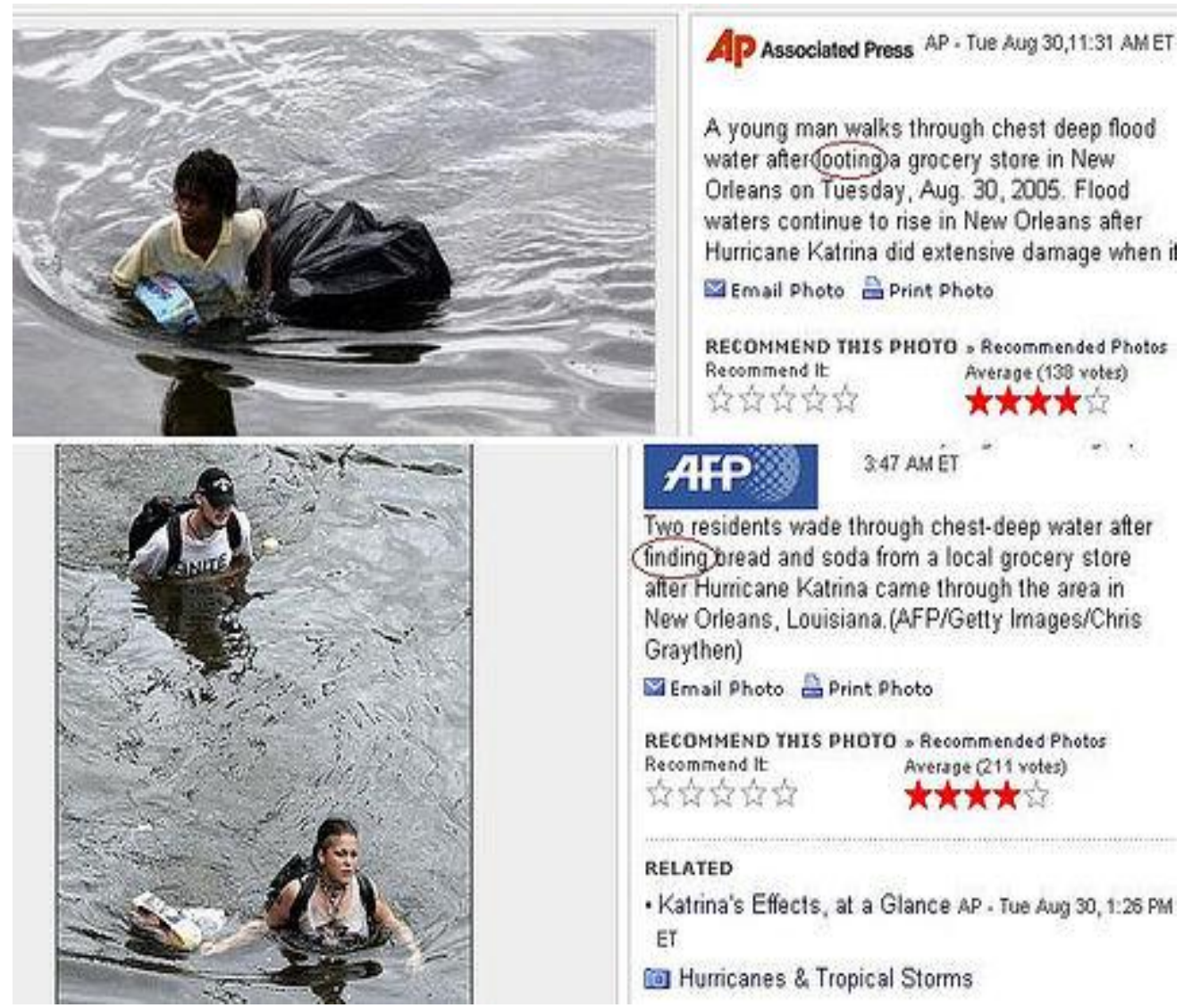

impossibilidade de sabermos em que condições reais cada fotógrafo se encontrava no momento de tirar suas fotos e, portanto, o quanto sabiam. Referindo-se a um artigo sobre o ocorrido, publicado na revista Salon ("'Looting' or 'Finding?' "), o texto reporta as versões das duas agências, ambas atestando a veracidade do que seus fotógrafos haviam testemunhado: o homem da primeira foto tinha sido visto pelo fotógrafo entrando no mercado e saindo de lá com os produtos, enquanto que o casal da segunda foto não havia sido flagrado saqueando e portanto não se poderia afirmar que o tivessem feito. Por fim, o texto reproduz o depoimento do segundo fotógrafo, justificando sua escolha ao dizer que realmente acreditava que os produtos haviam sido encontrados, e que apesar de haver várias outras pessoas por perto - negros e brancos essa era "a melhor foto" que ele poderia fazer.

Independentemente de se poder comprovar ou não os fatos - aquilo que "realmente aconteceu" -, importa-nos mais observar como os efeitos de verdade são construídos a partir de situações contingentes. Parece-nos que nada aqui poderia simplesmente "permanecer contingente", pois comunidades interpretativas ciosas de 
questões raciais vêem ocorrências desse tipo como reinstauradoras de uma estrutura jádada (pré-construída) de discriminação racial. O evento, nesse caso, reforça a estrutura, e as fotos e legendas que o representam servem-lhe de "documentos". A indeterminação dos sentidos não passa mais por uma mera questão estilística. A sinonímia simplesmente não existe quando saquear ou encontrar pode fazer toda a diferença na construção da identidade de um grupo social. Essa ligação entre significado e significante, marcada por uma relação historicamente construída de saber/poder, surge na superfície do discurso como um traço indelével, que não se apaga sob a rasura de uma língua aparentemente transparente e tranqüila de uma legenda de foto jornalística.

Como escreve Barry Allen: "para que o valor de verdade (e valores associados como referência, tradução, relevância, implicação, identidade, e objetividade) 'seja determinado', em qualquer caso, depende da efetividade de práticas historicamente contingentes de avaliação, e de nada mais” (1995: 110-1). Isso equivale a dizer que a diferença entre verdadeiro e falso não existe independentemente de uma prática local, na qual tais valores são produzidos e avaliados e os enunciados circulam como verdadeiros, apresentando-se sob a forma de fatos, notícias, "legendas”. "Somente aí os enunciados têm valor corrente, a capacidade de circular, de penetrar o raciocínio prático, de serem levados a sério, de se passarem por verdade.” (op. cit.: 4). Por força mesmo da tentativa de fixar os sentidos de uma prática em um regime de verdade, a contingência transforma-se em uma necessidade política a constantemente se justificar.

Uma outra suposta evidência de racismo é apontada numa mensagem de Brian Chapman, ainda do dia 2 de setembro, que reproduz o comentário de Wolf Blitzer, um conhecido âncora da CNN sobre desabrigados pelo Katrina em Nova Orleans:

"You see that picture [of people stranded on roofs or wading through water] over and over and over again but no matter how many times you see that picture, you simply get chills every time you see these poor individuals ... almost all of them are so poor, and so black..." (in: Blitzer pities Katrina’s victims, 2/9/2005)

Nesse caso específico, poderíamos dizer que a qualificação adjetiva de uma essência, um absoluto - ser black - surge aqui, em toda sua singularidade, como "perigosamente" depreciativa (so poor em justaposição a so black): a formulação de um enunciado que se 
inscreve em uma regularidade enunciativa ${ }^{29}$, sendo portanto acumulável e repetível. Uma evidência $e$ uma dispersão, para relembrar Pêcheux.

Ora, talvez não se pudesse esperar algo diferente de uma repercussão polêmica junto a quem, sensível à questão identitária, recebe o enunciado formulado pelo jornalista como sendo um sintoma, ainda que inconsciente, de um racismo arraigado. Tal enunciado se apresenta, nesse sentido, como uma espécie de desdobramento da luta permanente pela verdade.

Como vimos na discussão sobre o pragmatismo de Richard Rorty na seção anterior, metáforas surgem, e como resultado de um processo histórico de trabalho com a linguagem, literalizam-se. Daí então, literalizadas, formam a base para novas metáforas aparecerem. Algumas metáforas, no entanto, se sedimentam tanto que “apodrecem”. É o caso dos estereótipos, dos clichês, dos pensamentos prontos. A propósito disso, Barthes nos esclarece que o estereótipo é geralmente uma figura triste

“... porque é constituído por uma necrose da linguagem, uma prótese que vem tapar um buraco de escritura; mas ao mesmo tempo não pode deixar de suscitar uma imensa gargalhada: leva-se a sério; julga-se mais perto da verdade porque indiferente à sua natureza de linguagem: é ao mesmo tempo desgastado e grave.” (Barthes 1971/2004: 394)

O estereótipo é, assim, uma espécie de “verdade-coringa” que está sempre pronta a ser encaixada nas mais diversas contingências.

Em relação ao nosso material de análise, uma dessas metáforas necrosadas aparece sob o tropo do castigo divino (divine retribution). Figuras ligadas à religião ou à política, imediatamente reconhecíveis pelas posições previsíveis e predominantemente conservadoras que assumem - isto é, pelas formações discursivas mais ou menos estáveis de onde enunciam -, marcam presença em todos os fóruns de debate. E suas declarações são garantias de controvérsias não menos previsíveis. A atribuição de culpa, o merecimento do castigo, a exortação ao arrependimento: esses são temas recorrentes

29 Conforme observa Deleuze a partir do conceito foucaultiano de enunciado, “O que conta é a regularidade do enunciado: não uma média, mas uma curva. O enunciado, com efeito, não se confunde com a emissão de singularidades que ele supõe, mas com o comportamento da curva que passa na vizinhança delas, e mais geralmente com as regras do campo em que se distribuem e se reproduzem." (Deleuze 1988: 16) 
em suas falas, e eles parecem se aplicar, com pouca variação, tanto a terremotos na Califórnia quanto a tsunamis na Ásia, ou até mesmo a ataques terroristas como o de 11 de setembro de 2001. Tais figuras mudam levemente seus discursos, adaptando-os às circunstâncias específicas, mas pouco mais fazem do que remover o pó excessivo de seus arquivos um tanto desgastados. E o que encontramos nesses arquivos? Discursos sobre esses “outros” - americanos, muçulmanos, negros, judeus, homossexuais - que têm que pagar por seus pecados neste mundo.

Segundo essa lógica, sugeriu-se que fossem culpados pela devastação do Katrina os amantes da bebedeira, do jazz, da libertinagem sexual - esses “outros” que se encaixam em uma visão estereotipada de Nova Orleans. Sugeriu-se, em particular, que a comunidade homossexual, que se preparava, bem nessa época, para comemorar o já tradicional Southern Decadence (espécie de parada ou carnaval gay), estaria recebendo o castigo divino que lhes cabia desde já na bíblia. Sugeriu-se ainda, num golpe máximo de individualização de culpados, que a atriz e comediante lésbica Ellen DeGeneres, natural de Nova Orleans, teria sido responsável pela tragédia que atingiu a cidade, e que esse castigo teria vindo como resposta à escolha dela como apresentadora de um evento televisivo em rede nacional, a entrega dos prêmios Emmy da televisão americana... ${ }^{30}$

Mas eis que enunciados como esses, cristalizados porque reatualizados de forma tão previsível, acabam por receber a sanção dos membros do grupo de discussão que se ocupa em fazê-los circular e comentá-los. Lembremos: se uma das funções principais de que se incumbe essa comunidade virtual é a de desbancar rumores, aqui o trabalho parece mais simples, na medida em que os argumentos em que se baseiam tais histórias são, de antemão, facilmente desqualificáveis.

O discurso é rarefeito - desqualificado, ridicularizado, desacreditado - mas precisa antes ser devidamente comentado. Se uma polêmica se avizinha - uma dessas polêmicas polarizados do tipo "Mas de que Deus estamos falando: o Deus severo e punitivo do antigo testamento ou um Deus todo-amor, que jamais permitiria uma catástrofe como essa se abater sobre seus filhos?”31 -, o que vemos ocorrer é a pronta intervenção da mediadora da lista de discussão, a quem se atribui o poder (pelas regras da

\footnotetext{
${ }^{30}$ Referência a texto-paródia publicado no site Datelinehollywood.com, que, conforme atesta um dos membros da lista, foi amplamente (a)creditado, a julgar pela quantidade de blogs que se manifestaram furiosamente contra as supostas declarações do líder conservador cristão Pat Robertson feitas em seu programa de TV.

${ }^{31}$ Apenas a formulação particular (“minha”) de um enunciado imemorial.
} 
da comunidade) de impor limites a essa proliferação ao mesmo tempo inútil e “perigosa” de um discurso repetido. Um discurso que todos já ouvimos antes e que pertence talvez melhor a alguma outra lista. Escreve a mediadora, assinando-se Barbara "I can see a religious war coming a mile away" Mikkelson:

"Before this devolves into the usual 'My god is more crunchy and bettertasting than your god, watch what you're posting, sport, because not all of us believe the same thing' fight, may I remind those itching to get into it that such discussions are to be kept off the UL [Urban Legend] list? In place of this forum for such exchanges, I heartily recommend the interested parties privately email oneanother.”(in: divine retribution, 12/09/2005)

Os membros “iniciados” da lista, reconhecendo aí os limites institucionais dessa exclusiva “sociedade do discurso", podem até se dar o luxo de brincar com a situação. É o que ocorre na primeira mensagem subseqüente, em que o autor lamenta ter “apostado” 20 dólares com outro membro antigo da lista que alguém iria citar Hitler (dentro de no máximo duas mensagens mais) antes de despertar a fúria de Barbara! Já uma das participantes que suscitara a intervenção, novata ela própria na comunidade, viria se colocar na posição de censurada, e se desculpar. Mas não antes sem exibir sua ironia. Assinando-se Hope "I've been slapped good and proper" Hilandera, escreve:

"Nah. I know about the Hitler thing from Usenet. I also know about speeling and grammer [sic] from Usenet. I didn't know about the god thing because I'm new to this list, and it never came up before on other lists. My apologies to those who are sick of it, and certainly won't do it again.” (in: divine retribution, 13/09/2005)

Ora, o que temos aqui, em meio a esses pequenos embates? Eu diria: deslocamentos, resistências, exorcizações de discursos fantasmagóricos que ainda precisam ser ditos para ocupar o espaço incômodo de um silêncio inicial e aterrador pós-tragédia. Há mesmo uma lista de discussão que se incumbe de retransmitir esses discursos, falar deles... mas na condição de que se o faça dentro dos limites que uma dada ordem discursiva tenta impor aos sujeitos que nela circulam. Erra-se, portanto; 
insiste-se, mas dentro de uma regularidade discursiva que é construída na prática mesmo da proliferação dos discursos. Pode-se discutir de tudo na lista, incluindo os rumores mais improváveis, pode-se expressar crença ou descrédito neles; porém, quando se pressente a ultrapassagem dos limites de uma tácita "moderação políticaideológica”, trata-se logo de evitar que o fórum se transforme em uma arena de embates verbais potencialmente incontroláveis. Fundamental é que se mantenha o efeito de verdade, alimentado pelo acúmulo seqüencial de comentários.

E, algo que é singular nesse processo todo: a auto-reflexividade - o questionamento de “o que, afinal, estamos fazendo aqui nesta lista?” - não escapa aos participantes da comunidade. Ela aparece freqüentemente, aliás, como sugere, por exemplo, o seguinte trecho de uma mensagem enviada por Brian Chapman, um dos membros mais assíduos:

"It's also not surprising that some of the media uncritically accepted the rumors. Reporters see their duty as providing information, and they - as overwhelmed by the disaster as were the victims, politicians, bureaucrats, and the cops - sometimes tried to fill the information void with the only thing available: rumors. It happened after 9/11 and it will happen again. If it didn't, this listserv would be a duller forum." (in: Katrina, 21/09/2005)

\section{2. “Quem precisa de lendas urbanas?”}

E assim outros tantos rumores, das mais variadas espécies, continuaram a “preencher o vazio de informação” nos dias que se seguiram à tragédia, tanto nos veículos jornalísticos quanto nos blogs e listas de discussão. Alguns desses rumores envolvendo crimes e abusos foram repetidamente reportados por supostas testemunhas e avidamente anunciados em noticiários precipitados, na mesma proporção em que provaram, ao longo dos dias, se tratar de rumores não comprovados. Estupros e atos de violência contra crianças e mulheres nos abrigos de proteção, saqueio de armas de fogo, assassinatos cruéis, contaminação por ingestão de frangos arrastados pelo furacão até o litoral, ataques por tubarões e jacarés que nadam pelas ruas inundadas de Nova Orleans, 
até mesmo o uso pela máfia japonesa (a Yakuza) de um gerador eletromagnético de fabricação russa que estaria causando os furacões... a lista se prolonga. Em resposta a tantas especulações, jornais e outros veículos de mídia começam então a avaliar o peso negativo que tudo isso vem adicionar à situação já difícil enfrentada pelas vítimas. Um jornalista do New York Times coloca seu questionamento nos seguintes termos: "Even now, the real, actual events in New Orleans in the past three weeks surpass the imagination. Who needs urban myths when the reality was so brutal?” (Carr 2005) ${ }^{32}$.

Eu arriscaria dizer, a esse propósito, que não precisamos de mitos urbanos tanto mais do que precisamos de estatísticas ou fatos "substanciados" sobre os "reais e verdadeiros eventos em Nova Orleans”. As histórias simplesmente emergem, misturadas aos testemunhos, boletins policiais e fotografias periciais, entre tantos outros documentos. Elas entram a tecer o fio interdiscursivo que compõem os discursos que tentam significar uma tragédia, subjetivar as identidades dos indivíduos envolvidos, representar uma nação como um grupo homogêneo e sujeito a uma força de coesão em meio aos inocultáveis conflitos entre as comunidades - que é, ela mesma, uma vontade de poder/saber ${ }^{33}$. Essas histórias, em última análise, não são necessárias nem desnecessárias, nem mais nem menos indesejáveis, posto que são formas estruturais - $e$ também, em toda sua singularidade, acontecimentos enunciativos - de construir uma realidade, uma realidade que não dispensa a linguagem, e jamais poderá fazê-lo.

O breve percurso que acabo de traçar por um conjunto limitado de textos sirva talvez para começar a responder a questão: Como narrativas contingentes - no nosso caso, rumores, anedotas, relatos pessoais - podem se tornar lendas urbanas, entendidas aqui como enunciados repetíveis e acumuláveis, positividades (no sentido de Foucault), enfim, efeitos de verdade em gestação? A resposta desponta sob uma fugidia chama: elas o fazem na medida em que buscam fixar-se como “estruturas novas”, atravessadas

\footnotetext{
${ }^{32}$ Os textos jornalísticos citados literalmente nas análises estão incluídos entre as Referências bibliográficas - ver seção a) da Bibliografia.

${ }^{33}$ Ocorre-me aqui mencionar ainda a interessante discussão que Slavoj Zizek faz (embora em termos um tanto diferentes dos da minha) sobre o fenômeno Katrina, em um ensaio jornalístico de outubro de 2005. $\mathrm{O}$ autor chama de "mentiras disfarçadas de verdade" os rumores não-confirmados de violência e estupro envolvendo as comunidades negras afetadas pelo furacão. Quer dizer com isso que, mesmo que tais relatos se comprovassem factualmente verdadeiros, as histórias que circularam sobre eles seriam ainda sim "patológicas" (no sentido lacaniano de investimentos libidinosos inconfessos) e racistas, uma vez que sua motivação se encontra não nos fatos, mas em preconceitos, "[n]a satisfação experimentada por aqueles que poderiam dizer: 'Está vendo, os negros realmente são assim, bárbaros violentos sob uma fina camada de civilização!’” (Zizek 2005: 3).
} 
por discursos pré-construídos dos quais (aparentemente) se esquecem - formas estruturadas de violência, racismo e vitimização, por exemplo -, e firmar-se, assim, como um instrumento de saber/poder específico. Esse saber/poder é, em larga escala, paralisante, amedrontador, intolerante, mas é simultaneamente sintomático, pois "fala” uma contradição, apontando fraturas em uma sociedade que tenta fazer sentido de suas próprias tragédias. Essas narrativas são acontecimentos que buscam uma estrutura, mas são também uma estrutura que se desloca sem parar para além de sua tão provisória estabilidade.

Para concluir este capítulo e esta primeira parte do trabalho, gostaria apenas de me reportar a uma certa relação que se pode estabelecer entre a questão da verdade e as crenças, atitudes e ansiedades de uma comunidade. Tenho em mente especificamente as idéias de duas estudiosas de lendas contemporâneas, Whatley e Henken, já citadas no Capítulo 1 (seção 1.1). Para as autoras, a ressonância de uma lenda em uma determinada comunidade tende a ser maior que a evidência que contesta sua veracidade. Quer a narrativa seja ou não digna de crédito, o impacto que a força de sua mensagem pode causar não é necessariamente maior ou menor. Conforme apontam, “as evidências que se contrapõem à veracidade de uma lenda raramente carregam o peso que a lenda carrega (...) o impacto que uma lenda tem sobre os que a contam ou ouvem pode ter pouco a ver com acreditar-se ou não na história” (Whatley \& Henken 2001: 4).

Assim, pessoas podem não acreditar, por exemplo, que as latinhas de refrigerante que elas irão consumir tenham sido contaminadas por urina de rato, mas isso não as impede de limpá-las cuidadosamente com um guardanapo antes de abri-las. Elas podem não acreditar também que o uso de telefones celulares represente qualquer risco de explosão, mas isso não as impede de desligar seus aparelhos quando param para abastecer em um posto de gasolina. Quer dizer, o aspecto mais relevante sobre esse tipo de narrativa pode não ser sua verdade ou falsidade “objetiva”, mas sim aquilo que ela revela sobre as crenças e valores da comunidade em que circula. É o que começo a investigar no próximo capítulo, que abre a segunda parte do trabalho. 


\section{PARTE II - Lendas Urbanas como Práticas Discursivas}

\section{CAPÍTULO 4: Lendas Urbanas e as Ameaças do Cotidiano}

“[O] desenvolvimento técnico que acarreta o descrédito das ideologias não elimina a necessidade à qual elas correspondiam. Transforma as crenças em legendas ainda mais carregadas de sentido (qual? não se sabe mais). Marginaliza as doutrinas que, transmudadas em nuvens cintilantes, evocam sempre razões para viver."

- Michel de Certeau, A Cultura no Plural, 1974

“You just can't trust those damned cellphones... blowing up cars at gas pumps, attracting lightning, exploding batteries... electrocuting people when charging... and now... they change your thought patterns while you use them..."

- Roiz, urban-legends@yahoogroups.com, 2006

Um dos temas mais recorrentes das lendas urbanas é o das ameaças do cotidiano. Nas sociedades ocidentais contemporâneas, é comum a percepção de que vivemos numa cultura do medo, uma cultura marcada pela ansiedade de não mais se sentir protegido pelas instituições ou redes de segurança que em algum tempo do passado parecem ter fornecido a sensação, se não de total segurança, mas de alguma segurança. Mas o que nos ameaça nos tempos de hoje? Crimes violentos, doenças aterrorizantes, grandes transformações ambientais? Também, mas não apenas.

Aparentemente, estamos igualmente ameaçados por elementos que fazem parte do nosso cotidiano mais prosaico, o universo mais familiar e corriqueiro que nos cerca. Como nos lembra o sociólogo norte-americano Barry Glassner, “na maior parte, nossos medos são domésticos, e muitos são os sinistros invasores que os habitam - crianças assassinas, homens de cor, mamães monstro" (1999/2003: 330). Estamos ameaçados pelas novas tecnologias que vieram facilitar nossas vidas, agilizar nossos contatos, proporcionar-nos (pelo menos em princípio) mais tempo para sermos felizes. Estamos ameaçados pelo conforto de poder abrir mão da "obrigação" de cozinhar nossa própria comida, já que podemos escolher entre centenas de opções mais práticas e rápidas com que nos alimentar. Em uma escala ainda mais banal e insuspeitada, estamos ameaçados pelos desodorantes que usamos, pois podem ser cancerígenos; pelos fornos de microondas onde aquecemos nossas refeições, pelo mesmo motivo; pelos refrigerantes e 
cervejas que consumimos nos nossos fins de semana, uma vez que as latinhas que os contêm podem ter sido contaminadas por urina de rato. Isso para ficar só em alguns dos exemplos que figuram das mensagens que analiso neste capítulo, pois a lista continua.

Se na sociedade em que vivemos nos sentimos desprotegidos, buscamos cada vez mais nos cercar de objetos que nos tragam conforto, em nossas casas, em nossos bairros. Buscamos a sensação de contar com as coisas à mão, sem termos de pensar muito sobre como funcionam. O elemento não-previsto e o impensado é, então, aquilo que vem nos ameaçar - e esse elemento é corporificado na forma do estranho, do estranho familiar, pois está à nossa volta em toda a parte. Por mais que quiséssemos evitá-lo, não conseguiríamos. De uma certa forma, por serem próximas a nós, as ameaças tornam-se alvos visíveis e, assim, menos imponderáveis. Como bem observa Bauman, a presença do estranho é ao mesmo tempo perversa e confortante: “os temores difusos e esparsos, difíceis de apontar e nomear, ganham um alvo visível, sabemos onde estão os perigos e não precisamos mais aceitar os golpes do destino placidamente" (2003: 130).

Barthes também reflete sobre a "falsa inocência” dos objetos prosaicos quando trata dos motivos mais comuns no universo dos fait divers (ver sobre isso Capítulo 1, seção 1.2.2). A presença conspiratória desses objetos nas narrativas implica, segundo o autor, dois temas ideológicos: "por um lado, o poder infinito dos signos, o sentimento de pânico de que os signos estão em toda parte, que tudo pode ser signo; e, por outro lado, a responsabilidade dos objetos, tão ativos, no fim das contas, quanto as pessoas” (1966/2003: 63). Tal situação configura a idéia de que a causalidade está em toda a parte, e que portanto a realidade está eivada de acasos, forças que nos escapam. Mas também se pode pensar que, por estar sujeita à ação do homem, as causas se relacionam a esta ação de modo inescapável. Quer dizer, os instrumentos não têm simplesmente uma vida autônoma, independente do homem. Eles estão, antes de mais nada à mão, ao alcance do homem. Estão, como diria Heidegger, ao dispor do ser-aí.

Dentro desse raciocínio, há algo que nos ameaça bem de perto, mas há ao mesmo tempo e, por isso mesmo, algo que se possa fazer a respeito. Podemos evitar e nos prevenir contra os males, ou pelo menos acreditar que possamos fazê-lo, tomando medidas simples, de maior higiene e precaução, por exemplo, ou alertando os outros (entre outras formas, via encaminhamentos por e-mail) sobre os riscos que todos nós 
supostamente corremos. Nunca é demais prevenir e se prevenir, e, por via das dúvidas, um alerta na forma de lenda urbana pode ser tão válido quanto outro qualquer.

Ainda segundo Bauman, quando se pensa nas maneiras com que podemos melhorar nossas vidas, torná-las menos vulneráveis e inseguras, quase sempre são apontadas duas demandas que parecem as mais críveis e mais “auto-evidentes” e que, portanto, dispensam provas ou refutações. São elas: "a demanda de livrar a comida que comemos dos ingredientes prejudiciais e potencialmente letais que pode conter e a demanda de livrar as ruas por onde andamos dos estranhos inescrutáveis e também potencialmente letais” (2003: 130). Certamente, essas são demandas sobre as quais os indivíduos podem crer ter algum controle. Ao menos em princípio, os riscos da primeira podem ser evitados pela escolha criteriosa e bem informada sobre o que ingerimos, onde e quando - em última instância, trata-se de uma demanda que incide sobre nosso próprio corpo, e o que decidimos fazer com ele, incluindo aí as ginásticas, as terapias, e os tratamentos estéticos, tão em evidência. Quanto à segunda demanda, talvez mais difícil, os mecanismos de vigilância cada vez mais sofisticados em que nossas sociedades investem asseguram parte da resposta. Como bem sabemos, o ubíquo slogan “Sorria: você está sendo filmado” está longe de soar como um mero apelo à simpatia. Câmeras de circuito interno, seguranças, alarmes que disparam nas lojas, tudo conspira para uma aparente sensação de proteção do espaço físico social contra aqueles “estranhos inescrutáveis e também potencialmente letais”.

Com essas reflexões iniciais em mente, proponho-me neste capítulo a tratar de algumas das ameaças do cotidiano cuja presença se fez marcar em vários dos threads de mensagens do corpus no período selecionado para análise. Olhando de uma forma geral para esses threads, destacaram-se, de início, três grandes conjuntos de questões: (1) o medo e as supostos riscos causados pelas novas tecnologias no cotidiano, com foco no uso dos telefones celulares, (2) o problema da contaminação ou adulteração de produtos alimentícios - como vimos, uma das facetas do estranho sugeridas por Bauman - e (3) a violência e insegurança que ameaçam as pessoas em lugares públicos, especialmente em shopping centers e hipermercados. Em vista dessa composição, dedicarei a cada uma dessas questões uma seção do capítulo, explorando em mais profundidade os temas e, particularmente no caso das duas primeiras, as discussões levantadas pelos membros da comunidade virtual. 


\section{Os Tecno-Medos}

As apreensões e ansiedades geradas em uma sociedade marcada por avanços científico-tecnológicos cada vez mais pervasivos e rapidamente substituíveis fornecem freqüentemente o material de que as lendas urbanas são feitas. Como destaca Emmanuel Taïeb, o rumor (e por extensão, a lenda urbana) expressa, em plena era da comunicação eletrônica, "a reação, a recusa de ver mudar os hábitos, a desconfiança diante do progresso” (2001: 258). O medo da novidade e a aversão à ciência e a nova tecnologia não são em si mesmos temas novos, certamente. A fobia a computadores (se é que ainda possa existir) substituía a desconfiança quanto à televisão, e esta, por sua vez, se sobrepunha à resistência ao rádio, e assim poderíamos traçar a história retrospectivamente. Isso tudo até esses meios terem se tornado, nos tempos atuais, "tão naturais quanto o ar que respiramos”.

Quando os primeiros fornos de microondas surgiram no mercado, toda espécie de mito e desinformação surgiu em seu rastro. O simples ato de aquecer um copo d’água num desses fornos parecia esconder mistérios insuspeitáveis. O uso de determinados materiais em seu interior, como o plástico e alumínio, até hoje confundem usuários pouco informados sobre os verdadeiros riscos envolvidos. Em alguns casos extremos, a mera falta de familiaridade com o funcionamento dos produtos produz resultados desastrosos. Relatos dão conta de bebês e animais de estimação que acabaram “cozidos” no microondas pois seus responsáveis julgavam ser esse um método mais rápido e eficaz de secar as criaturas (Fine 1992: 153; Brunvand 1999: 290-1). Mas mesmo antes disso, elas sofriam destino semelhante sendo expostas a fornos convencionais, secadores de cabelos e máquinas de lavar! (Vos 1996: 103).

O uso de telefones celulares - invenção um pouco mais recente que os microondas - nos fornece amplo material de investigação, tamanho o número de relatos envolvendo esse pequeno mas poderosíssimo aparelho da sociedade contemporânea. Longe se vai o tempo em que as pessoas julgavam ser preciso gritar ao telefone (tradicional) quando em uma ligação interurbana, e não tão longe assim o tempo em que se acreditava que os telefones celulares poderiam literalmente “fritar” nossos miolos (Burgess 2004: 1). Os mitos hoje são outros. Entre os mais comuns deles, o de que usar telefone celular próximo a uma bomba de gasolina pode desencadear uma explosão. Nas seções que se seguem, examino um conjunto significativo de mensagens do nosso 
corpus que têm os telefones celulares como protagonistas. Veremos como o lendário em torno desses aparelhos parece não ter limites.

\subsection{Celulares Explosivos}

Em março de 2005, o membro da lista Brian Chapman envia à lista de discussão duas reportagens desmistificando a crença de que o uso de telefones celulares próximo a bombas de gasolina poderia causar explosões. A primeira reportagem, do dia 20, publicada no jornal escocês The Scotsman com o título "Mobile Dangers at Petrol Stations Dismissed", anuncia os resultados de um estudo indicando que, dos mais de 200 incêndios ocorridos em postos de gasolina em um período de 11 anos, nenhum teria sido induzido. Adam Burgess, sociólogo inglês que escreveu uma obra sobre a relação entre uma cultura do medo em torno do uso de celulares e a excessiva preocupação com segurança e saúde nas sociedades contemporâneas, é citado na reportagem dizendo: “ $A$ história posto de gasolina/telefone celular cruza o limiar do rumor e da lenda urbana. Ela é verdadeiramente infundada, uma história enlouquecida sobre saúde e segurança” (Williams 2005). A segunda reportagem, do dia 23, publicada na revista inglesa The Economist com o título “Anatomy of a Techno-Myth”, sugere que o debate sobre a segurança envolvida no uso de celulares é menos uma questão científica que sociológica. Diz o texto: “[A] preocupação repousa não sobre a comprovação científica de qualquer perigo, mas é antes o resultado de fatores sociológicos: trata-se de um mito urbano, sustentado e propagado por fontes oficiais, mas não menos um mito urbano”. Motivadas por versões desse mito urbano circulando há anos pela Internet e outras fontes, e apesar dos diversos desmentidos e estudos já publicados, autoridades de vários lugares do mundo (entre os citados, a cidade de São Paulo) mantêm a proibição do uso dos aparelhos em postos de gasolina. A reportagem também cita Burgess, que conclui haver uma discrepância entre o fato de os celulares terem se tornado objetos praticamente indispensáveis nos dias de hoje - seu uso tendo se multiplicado nos últimos anos - e a vaga percepção de que esses aparelhos possam causar algum risco à saúde e à segurança de seus usuários.

Os esclarecimentos parecem todos muito convincentes. E a lista de discussão está, de certa forma, “cumprindo sua parte”, ajudando a desbancar os rumores, dissipar a desinformação ao propagar artigos como esses. Mas enquanto certos mitos são 
desbancados, outros continuam à espera de esclarecimento. Pelo menos é o que se pode aparentemente concluir pela resposta de Andrea Tringo, que, tendo feito sua "tarefa de casa”, envia à lista a seguinte mensagem, sete dias depois ${ }^{34}$ : “Yes, but I was hoping the one about static electricity from your clothing was a myth. It's not, and I read about a few in Denver where I live. After that, I never wanted to have my dog in the car when I fueled up." Se a eletricidade estática é a verdadeira fonte da maior parte dos incêndios, é preciso dizer que roupas e pêlos de animais domésticos, podem sim, conforme mais um “suposto mito”, desencadear as faíscas. Para atestar sua informação, Tringo remete a uma reportagem da $C N N$ de 2002 relatando o caso de uma garota (na época com 12 anos) que, ajudando a mãe a abastecer seu carro em um posto, teve suas vestes - um suéter e uma jaqueta - incendiadas ao tocar a mangueira.

Podemos observar aqui já um interessante movimento, em que mitos são desbancados, mas também confirmados (como esse último), clamando, por assim dizer, alcançar o estatuto de fato atestado. Se os veículos de comunicação não esclarecem todos os mitos envolvendo o uso de celulares e riscos de incêndio, é preciso fazer a tarefa de casa, procurar saber mais, “escarafunchar”. E para isso, mais relatos de experiências pessoais se fazem necessários, mesmo que esses relatos permaneçam perdidos vagamente numa onda (nada estática) de propagações rumorosas! O caso da garota, por exemplo, vem circunstanciado pela $C N N$, que é um órgão da mídia de grande repercussão. Outros casos terão sido circunstanciados em outros meios de comunicação, em outras ocasiões, com variáveis graus de ressonância. Mas tantos outros supostos relatos não terão o mesmo "estatuto discursivo”. Cruzarão, mesmo, o limiar do rumor e da lenda urbana, como observou Burgess. Serão transmitidos em alertas apócrifos (assinados ou não), confundindo ainda mais uma sociedade "vaga e dispersamente preocupada” com os perigos dessas maquininhas sem as quais não consegue mais viver.

Ao que parece, nem as notícias de jornal nem os mitos urbanos podem contar toda a verdade sobre os incêndios em postos de gasolina, muito menos sobre os perigos do uso de telefones celulares. O lendário, aqui, como processo discursivo, permanece em plena formação, estando sujeito a inclusões e renovações constantes.

\footnotetext{
${ }^{34}$ Aqui a resposta é dirigida a uma mensagem de James Callan, que (por o que acredito ser uma coincidência) postou exatamente a mesma reportagem do The Economist, seis dias depois de Chapman.
} 


\subsection{Em caso de emergência...}

A possibilidade de entrar em contato com alguém imediatamente e de qualquer localidade no caso de uma emergência é certamente uma das vantagens de se possuir um aparelho de telefone celular. Nosso próximo caso ilustra bem isso. No dia 24 de julho de 2005, James Callan envia uma mensagem que, segundo ele, lhe havia sido encaminhada em uma outra lista de discussão da qual fazia parte, o que o levava a crer se tratar de um texto já em ampla circulação. Nele ficamos sabendo da sugestão de um serviço de atendimento médico emergencial em East Anglia, Inglaterra, dias após uma onda de atentados a bomba em Londres, de se adotar um código internacional para ajuda imediata em casos de emergência. Consiste no registro das iniciais I. C. E., que em inglês lêem-se justamente "em caso de emergência” (in case of emergency), na agenda de endereços dos aparelhos celulares. O objetivo seria usar o código para tornar mais fácil e rápido o acesso a pais ou responsáveis de portadores que tenham sofrido algum acidente e estejam impossibilitados de se comunicar. O texto atribui a autoria da idéia a um paramédico não nomeado e cita o veterano da Guerra das Malvinas, Simon Weston, como um dos propulsores da campanha. Bem no estilo de uma corrente, encoraja-se o leitor a adotar a medida e solicita-se que a mensagem seja retransmitida ao maior número possível de pessoas.

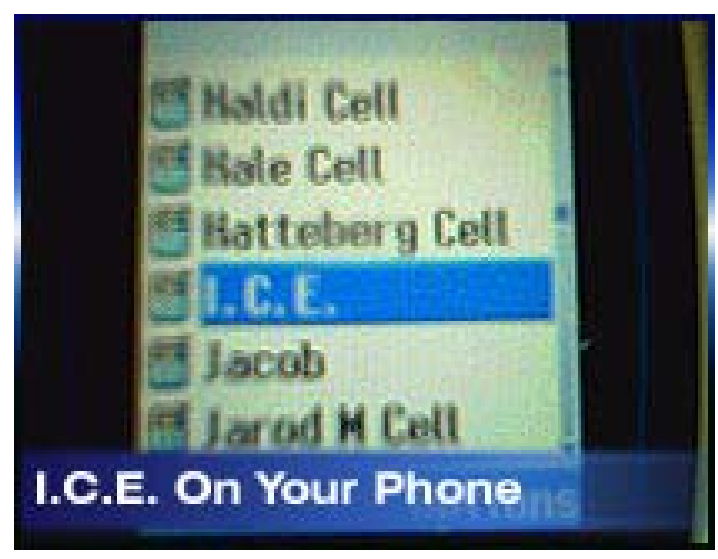

Poucas horas depois, começam a chegar as primeiras respostas, e elas refletem uma variedade de reações. Um diálogo se trava, cujo fio condutor dessa vez não se dá na tentativa de provar ou desbancar a "veracidade” do relato. Antes disso, trata-se de avaliar a própria efetividade da idéia, ou, em outras palavras, legitimar ou não um saber. Jeannie Stuart aprova a idéia, seja o relato verdadeiro ou não. Elisabeth Van Every cita 
um artigo de uma rede de TV de Seattle sobre o assunto. Diz que um amigo seu policial começou a espalhar a idéia e que seu marido, agente da polícia militar, adotou a medida com seu próprio celular, embora ela não soubesse dizer se ele também estava disseminando a campanha. Já Kathy Kirkpatrick expressa suas reservas ao sucesso da idéia. Admite que a intenção é boa, mas argumenta que em casos de grande tumulto, como um atentado, é grande a chance de as pessoas se verem separadas de seus aparelhos (numa correria ou empurra-empurra, por exemplo). Assim, em meio a uma quantidade grande de aparelhos perdidos, como saber a quem pertencem, e a quem reportar? Para ilustrar seu ponto, cita o caso da filha de uma colega de trabalho que, durante o atentado de 11 de setembro de 2001, se envolveu em uma situação semelhante. Jeannie replica que ainda assim a medida funcionaria bem em situações de acidentes automobilísticos. Paul Bowers ironiza, sugerindo a adoção de tatuagens codificadas em diversas partes do corpos. Roiz vai mais longe: diz que programou o seu I.C.E. para chamar um servidor de mensagens que irá fornecer informações essenciais como "He has health insurance”, "He has a great lawyer”, "Nope, no life insurance”, ou "No organs worth donating”... Até mesmo Barbara Mikkelson, a moderadora do grupo, acrescenta uma experiência pessoal (em seu caso, algo raro) para ilustrar a idéia de que, mesmo em um acidente de carro, não se pode contar com a presença próxima de um celular. Quando criança, morava vizinha a um cruzamento de estradas em que acidentes eram muito freqüentes. No dia seguinte a um desses acidentes, lembra ter encontrado um pé de sapato que teria voado para longe de um dos carros e que só poderia ter pertencido à única mulher que estivera envolvida no desastre. Como também testemunhara o acidente, Barbara lembra ainda ter ouvido os paramédicos se perguntando, durante o resgate, onde teria ido parar o tal sapato.

A discussão prossegue com membros da lista ponderando sobre a vantagem de se usar outras formas de promover o contato com a família e/ou amigos de vítimas em casos de emergência. Liz Patton, que trabalha no setor de emergência em um hospital, relata com certo detalhe o que costuma ocorrer quando pacientes incapacitados de se comunicar verbalmente chegam ao local. Enquanto não vê problema algum em se adotar o código I.C.E., ressalta que o celular tende a ser a última coisa que os funcionários pensam em checar. Normalmente, estes buscam cartões de identificação de condições médicas (como diabetes, por exemplo) ou braceletes e colares - ela mesma possui um - contendo não só dados para contato mas todo um histórico médico da 
pessoa. Mas nem mesmo esses recursos parecem funcionar totalmente, ainda segundo um outro participante! Dave Williams relata o caso de sua mulher que, sofrendo de diabetes e portando um bracelete de alerta, passou por três diferentes internações emergenciais sem que em nenhuma delas qualquer funcionário tivesse a mínima idéia do propósito a que este servia, tendo mesmo a ignorado quando ela tentava avisá-los. Conclui Dave: "Yeah, it could have been three bad rolls of the dice, but it was still a waste of time when she needed it." No que é secundado por outro participante (denominado “idigforyou”), que afirma ter desistido de usar o bracelete depois de passar pela mesma experiência em duas situações, uma nos Estados Unidos outra na Inglaterra.

Ora, parece que se está construindo pouco a pouco diante dos leitores da lista um painel cético, se não pessimista, do alcance efetivo de uma idéia que, em sua intenção, revela-se muito simples. É como se todas as reservas e eventuais complicadores fossem fortes o suficiente para desprezar a possível eficácia de uma medida como essa. Isto é, uma idéia que a princípio "não custa nada” - "First, I'd file this one myself under 'Well, it can't hurt'”, pontua Joe Yuska, outro participante - padece sob o efeito de um discurso que tende a "silenciar" o elemento edificante (nos moldes de um manual de auto-ajuda) da campanha pró-I.C.E. com base na descrença e/ou na experiência pessoal $^{35}$. Ou seja, no espaço do interdiscurso, materializado pelas formulações múltiplas dos interlocutores, duas formações discursivas distintas tendem a polarizar o debate, "entricheirando" os argumentos: de um lado, o discurso do self-help, do “indivíduo que ajuda-se a si mesmo”; de outro, o discurso racional e cético, segundo o qual “o que tiver de acontecer, acontecerá”.

Nesse sentido, uma boa chave para entender a motivação por trás do debate vem do próprio Yuska, quando diz: "It seems to me that among the deep universal fears that humans share is the vision of leaving this earth so completely that no one knows what happened to us”. O que estaria em jogo é a fragilidade e a impotência experienciadas diante do imponderado. O medo da morte, por certo, mas antes, o medo de morrer incógnito, abandonado a um destino que pode ser insustentavelmente contingente. Morrer assim, sem mais nem menos, sem poder fazer nada, e separado de seu elo mais imediato com o mundo: o celular... eis um destino ingrato.

\footnotetext{
${ }^{35}$ Reporto-me, nessa conexão, à seguinte passagem em Bakhtin: “A concepção do seu objeto, por parte do discurso, é um ato complexo: qualquer objeto 'desacreditado' e 'contestado' é aclarado por um lado $e$, por outro, é obscurecido pelas opiniões sociais multidiscursivas e pelo discurso de outrem dirigido sobre ele" (1934-5/1990: 87).
} 
Enquanto isso, argumenta R. Culpin, cidadãos comuns, especialmente cidadãos americanos, deixam de prevenir a morte prematura com hábitos de vida mais saudáveis - menos sedentarismo, menos consumo de alimentos ricos em sal e gordura e menos programas de notícias sensacionalistas - preferindo acreditar que as chances de morrer vítimas de atentados são maiores do que realmente são. No que tem a simpatia de Marilyn Shaw, que sentencia: "We spend too much time worrying about things we can't change, but no time changing the things we can change.” Ponto para quem acredita que os alarmismos e mitos urbanos que os materializam funcionam como válvulas de escape para os "reais" problemas de uma sociedade - ou, pelo menos, aquela espécie de problema que parece estar ao nosso alcance de mudar.

Seja como for, 15 dias após a primeira mensagem enviada sobre o código I.C.E., após um breve intervalo nesse thread de discussão, Josh Beckett escreve, da Austrália, contando que acaba de receber uma mensagem de texto de sua operadora de telefonia celular sugerindo a opção de registrar o código em caso de emergência! O que o leva a concluir: "Looks like this legend is turning into fact...". E o que nos leva a concluir: os limites de onde começa o fato e termina a lenda, e vice-versa, são, em última instância, indecidíveis.

\section{Dedos, ratos e outros corpos estranhos}

Outro motivo que domina o cânone das lendas contemporâneas é o da contaminação. Conforme aponta Trubshaw (2002), o escopo varia da invasão de corpos por répteis, aranhas ou insetos, passando por cobras ou tarântulas escondidas em plantas, aparelhos eletrodomésticos ou roupas nas prateleiras de lojas, até a mais comum das formas: a contaminação de alimentos. De fato, vivemos em uma cultura em que as opções de alimentos e bebidas industrializadas e de espaços para o consumo destes tornaram-se infinitas. Os fast-foods, os bares e restaurantes, os hipermercados, as praças de alimentação de shopping centers se proliferam numa oferta constante de alimento e prazer.

Embora tenhamos cada vez mais à disposição informações sobre o valor nutricional dos alimentos - a quantidade de calorias encontrada em cada produto, o consumo máximo diário recomendado para cada nutriente, os riscos que as diversas 
formas de gordura podem trazer à saúde, entre tantos outros - e com isso possamos programar, balancear nossas dietas de acordo com nossas necessidades e, de preferência, com o objetivo de uma vida mais saudável, sentimo-nos também afastados dos processos cada vez mais sofisticados de elaboração e distribuição dos alimentos, principalmente quando os consumimos fora de nossas casas. Fazer refeições em restaurantes ou lanchonetes há muito tempo deixou de ser um hábito esporádico ou restrito a populações com maior poder aquisitivo. Hoje em dia pululam os restaurantes que vendem comida a quilo, onde se pode comer barato, rápido e todos os dias, e variando o cardápio. Pode-se também, cada vez mais, pedir todo tipo de comida para ser entregue em casa.

Em todos esses casos, por mais que vejamos o alimento à nossa frente, continuamos sem ter uma garantia absoluta de que as normas mínimas de higiene e manipulação desses alimentos estejam sendo seguidas. Podemos até visitar as cozinhas, mas isso não nos assegura de muita coisa. Agimos, de fato, na base da confiança. E, aparentemente, confiamos cada vez mais, uma vez que mesmo as refeições mais corriqueiras - o arroz-e-feijão do dia-a-dia - parecem vir de outro lugar. Enunciados como “As mães de hoje não cozinham mais” ou “As esposas hoje em dia mal sabem fritar um ovo” reverberam ainda uma memória, apontando para uma tradição que parece cada vez mais deslocada.

Estamos, enfim, diante de um universo de facilidades e praticidades que se integra muito bem ao ritmo de vida acelerado e eficiente a que nos submetemos, mas que no entanto não está livre de surpresas muito desagradáveis. Não estamos isentos, como sugere a página sobre comida do portal de lendas urbanas Snopes.com, de encontrar restos de animais, urina e outros fluidos em comidas e bebidas servidas em restaurantes, ou de adquirir doenças pelo consumo de produtos químicos como o glutamato de sódio presente em diversos alimentos industrializados. Obviamente, as lendas tendem a reportar casos extremos, mas a sensação do risco, o efeito de ameaça generalizada, não deixa de existir; soa, ao contrário, bastante plausível, uma vez que pode atingir a todos nós, consumidores freqüentes ou potenciais. Como observam Campion-Vincent e Renard: "Participando de sistemas hipercomplexos sem os poder controlar, os consumidores desorientados escutam todo tipo de rumores negativos, rumores freqüentemente difundidos sem discernimento por uma imprensa sensacionalista que privilegia a manchete alarmista.” (2002: 29) 
Para começar a explorar esse tópico, cujos episódios são definidos por esses últimos autores como "pânicos alimentares”, vejamos a seguir como foi documentado no corpus de 2005 um episódio ocorrido num dos incontáveis locais de consumo rápido de comida nos Estados Unidos: a rede de restaurantes Wendy’s.

\section{1. “Garçom, tem um... dedo no meu chilli!”}

Como faz regularmente na lista de discussão, Brian Chapman envia ao grupo, em 24 de março de 2005, uma notícia de jornal cujo “potencial de lenda urbana” lhe parece relevante. É muitas vezes assim, aliás, que começam as discussões: determinado material factual que evoca, remete a, ou soa como lenda urbana é lançado como um novo elo no processo de disseminação e reciclagem do arquivo. É o caso da notícia em questão, citada diretamente do San Francisco Chronicle, com o título: “Wendy's diner finds human finger in her chilli". Trata-se do relato de uma mulher que jantava na rede de restaurantes em San Jose, Califórnia quando teve o infortúnio de morder parte de um dedo humano, bem cozido, encontrado na tigela com chilli que estava comendo. Segundo agentes de saúde citados na reportagem, a mulher cuspiu fora o corpo estranho, notificou os funcionários do restaurante e começou a passar mal do estômago. Mais tarde, ela receberia a confirmação de que se tratava mesmo de parte de um dedo humano, com aproximadamente 4 centímetros, mas que os riscos de contaminação ou qualquer outro dano à saúde eram praticamente inexistentes. Coletado o material para investigação e tomadas outras medidas de prevenção, o restaurante, que ficara fechado por algumas horas, retomou as atividades em seguida.

Quatro dias depois, o mesmo membro do grupo envia outra mensagem, citando reportagens posteriores que traziam novos desdobramentos do caso. Numa dessas reportagens, publicada no San Jose Mercury News no dia 26 de março, a “vítima”, agora já identificada como Anna Ayala, de 39 anos, zeladora desempregada, residente em Las Vegas, teria contratado um advogado com o objetivo de acionar judicialmente o restaurante, que a essa altura já contava com uma queda considerável em relação a seu movimento habitual. Muitas questões permaneciam então sem resposta, as principais delas sendo: como um dedo teria ido parar num prato de comida, e a quem pertencia? Nesse momento já se cogitava a possibilidade de o dedo ter sido incluído depois, durante o processo de manipulação e pós-preparação do alimento no próprio restaurante, 
e não de ele ter vindo do distribuidor. A hipótese não isentaria nem mesmo a própria mulher da acusação de ter “plantado” o dedo lá por sua própria conta, o que ela obviamente negou.

No dia $1^{\circ}$ de abril, mais uma atualização sobre o caso traz a informação de que havia sido coletada uma impressão do dedo encontrado mas que não havia ainda sido possível identificar a quem pertencia. Somente três dias depois viria o primeiro comentário de um membro do grupo de discussão, Shona, a respeito dessa história. Trata-se de um comentário irônico, de alguém que está acompanhando a história como uma investigação policial, com seus desdobramentos e atualizações constantes, mas que não está levando nada muito a sério. Em uma simples frase, sem nada mais acrescentar, indaga a leitora: “Have they tried searching the Koala fingerprint database yet?”.

Ao longo da semana seguinte, novos updates, sempre enviados por Brian Chapman, dão conta de que a suposta vítima já possuía um histórico de disputas legais, incluindo uma em 2003 na qual acusara um outro restaurante pela contaminação por salmonela que atingira sua filha após uma refeição no local - tendo obtido com sucesso uma indenização no valor de 30.000 dólares. Sua casa em Las Vegas seria ainda revistada pela polícia local e de San Jose em busca de mais elementos para investigação. Indignada com o que chamou de “caça às bruxas”, pelo modo como teve sua residência “invadida” e como sua filha de 13 anos foi tratada pelos investigadores, e também com as acusações de que estaria forjando todo o caso para obter compensação financeira - à qual rebateu afirmando que, ainda que estivesse afastada havia um ano de sua profissão em virtude de uma lesão no pé, sua condição financeira era bastante estável e que, portanto, não precisava de dinheiro -, Anna Ayala sinalizava com a determinação de levar o caso até as últimas instâncias legais. Alguns dias depois, porém, uma reportagem do The New York Times indicava que, por orientação de seu advogado, Ayala não tinha mais a intenção de processar a rede de restaurantes Wendy’s por julgar que o constante assédio da mídia vinha causando distúrbios e estresse emocional contínuos para ela e sua família. Nesse mesmo dia, 13 de abril, um segundo comentário da lista era postado por Gary, que também ironicamente sugere o malefício de se alimentar (com freqüência) em restaurantes do gênero. Diz o comentário: "If it put her of[f] eating fast foods, she should be thanking them!”. A julgar por essa reação, a atitude de Ayala em relação ao caso tende a ser vista com maus olhos, ou pelo menos desconfiança, por parte dos que acompanham a história. 
No dia 22 de abril, chega a notícia de que Anna Ayala havia sido presa por suspeita de fraude, enquanto a rede de restaurantes em questão já acumulava um prejuízo de aproximadamente um milhão de dólares ao dia e uma verdadeira crise de relações públicas. Por todo o país, além da sensível queda de movimento, a rede enfrentava ainda uma série de “farsas oportunistas" de clientes que alegavam ter encontrado unha, pedaço de madeira e osso de galinha nos pratos ali servidos. Com a prisão de Ayala, os negócios começaram a melhorar um pouco, com freqüentadores sensibilizados pela situação da empresa e de seus funcionários, ou simplesmente atraídos por promoções motivadas pelo caso, retornando aos poucos aos restaurantes da rede. A impressão mais ou menos generalizada entre essas pessoas era a de que a empresa, seus funcionários e a comunidade seriam as verdadeiras vítimas da história.

De fato, como apontou um editorial do jornal San Francisco Chronicle na ocasião, é impossível calcular quantos clientes jamais voltarão a comer no Wendy’s, assim como aqueles que jamais voltarão a freqüentar uma outra rede (a Kentucky Fried Chicken) que se tornou alvo de uma outra lenda urbana, já clássica, na qual a cabeça de um rato frita foi encontrada numa porção de frango. Conclui o editorial: "Para o Wendy's, a vingança por meio da aplicação da lei [no caso, contra a suposta tentativa de fraude da Senhora Ayala] pode resultar muito mais simples do que a tarefa de fazer o público esquecer as piadas e a péssima imagem que definiu a cadeia de fast-food ao longo de um mês terrível".

A “verdade dos fatos”, revelada no mês seguinte, dava conta de que tudo não passara de uma grande fraude arquitetada por Ayala e seu marido James Plascencia, de 43 anos. O dedo pertencia a um colega de Plascencia que, para quitar uma dívida de jogo no valor de 50 dólares com este último, lhe cedera, aparentemente sem saber do propósito a que se destinaria, o pedaço do dedo que perdera em um acidente sofrido meses antes numa máquina da empresa de pavimentação em que ambos trabalhavam. $\mathrm{O}$ presidente da empresa havia telefonado para uma linha de denúncia da polícia, que na ocasião oferecia 100 mil dólares em recompensa para uma pista que levasse ao esclarecimento do caso. Em setembro daquele ano, Ayala e Plascencia se confessam culpados de conspiração contra a rede de restaurantes e, em janeiro de 2006, ela é condenada a nove e ele a doze anos de prisão.

De um determinado ponto de vista, a história do "dedo na tigela de chilli” poderia ser visto como mais um fait divers curioso envolvendo um suposto flagrante de 
negligência alimentar por parte de uma corporação e que, por meio de uma diligente investigação policial, não provou ser mais que uma farsa. Até certo ponto, é disso que se trata, realmente. No entanto, a memória ativada por um arquivo de lendas urbanas com motivação alimentar vem, de certo forma, reclamar para si mais essa história. Em outras palavras, como vimos repetindo ao longo deste trabalho, temos aqui uma estrutura que busca incorporar um novo acontecimento.

E isso vem a se dar não simplesmente como uma mera adição a uma lista relativamente extensa e conhecida de lendas urbanas dessa linhagem - rato na coca-cola e no frango frito, sêmen na maionese, urina na cerveja, sangue contaminado com HIV no catchup, arame no hambúrguer ${ }^{36}$-, mas antes como um deslocamento dessa memória, uma reatualização em novos termos, sob um novo enfoque, sob um novo foco de ação. O que a história do dedo no chilli traz de peculiar (não só ela, mas particularmente ela) é a prática denominada ostensão (“ostention”). Trata-se de imitar, na "vida real”, a ação ou tipo de ação descrita por uma lenda urbana de conhecimento público (Fine 1992: 205; Ellis 2001: 161-4). O ato de colocar um objeto estranho em um determinado alimento com vistas a acusar falsamente um estabelecimento e assim obter recompensa financeira encontra ressonância não apenas numa cultura de vitimização que encoraja e ampara legalmente a reivindicação individual por perdas e danos nas mais peculiares e inusitadas instâncias da experiência social, mas também e, mais especificamente, numa cultura de narrativas esparsas, apócrifas (porém reincidentes) de lendas urbanas envolvendo essa espécie de companheiro fiel e ao mesmo tempo inimigo público que são as grandes corporações de fast-food.

No que o sociólogo Gary Alan Fine chamaria de Efeito Golias (1992: 143-6), temos aqui a encenação de uma falsa querela entre, de um lado, o indivíduo consumidor, fragilizado diante da impotência de controlar os processos de produção e distribuição dos alimentos que ele ou ela escolhe para consumir e, de outro, a toda poderosa indústria da alimentação rápida, que, ávida por obter margens de lucro cada vez maiores, explora uma mão de obra barata e pouco qualificada e dessa forma potencializa as escalas de produção/distribuição, das quais nem ela mesma pode garantir

\footnotetext{
${ }^{36}$ Para citar apenas alguns dos vários listados e discutidos na galeria de lendas urbanas envolvendo contaminação em comida do site Snopes.
} 
o absoluto controle ${ }^{37}$. Pois bem, o Davi consumidor vence o gigante Golias obtendo na justiça o direito a ganhos compensatórios, sem falar na incontornável exposição e desgaste da imagem da empresa, que passa a partir de então a experimentar um declínio de vendas.

Há que se pesar ainda nesse caso um elemento que não nos passa despercebido: se os funcionários da Wendy’s são em grande parte imigrantes latinos, também é latina a falsa querelante. Mexicana, Ana Ayala presentificaria, de uma certa forma, a imagem desse “outro" vitimizado pelos mecanismos avassaladores do capitalismo comercial norte-americano. Como indicado pelo seu histórico de disputas legais, Ayala aprendeu a lutar contra tudo e contra todos, assumindo uma agência resistente (mas desonesta, como provou ser o caso), pela qual se coloca como uma vítima mais ostensivamente marcada, ou seja, uma Davi mulher, imigrante, mãe de família e pobre - mas ainda assim capaz de trabalhar e, portanto, capaz de agir em nome da “justiça” e da proteção à família mais do que propriamente por necessidade econômica, como ela própria teria declarado. Esse é o enredo narrativo que se constrói, a partir de outros enredos narrativos que nos contam a mesma história.

Melhor dizendo, é uma narrativa que se constrói, projetivamente, a partir de motivos identificáveis. Pois não é necessariamente esse o enredo que irá se impor a boa parte das pessoas que, conforme vimos, julgaram o caso suspeito desde o início. Aqueles que retornaram ao Wendy's, independentemente de tê-lo feito em busca da promoção de smoothies gratuitos, “cheiraram um rato” nessa história, como oportunamente ilustra a expressão inglesa (smell a rat). Quer dizer, se essas pessoas, juntamente com os membros da lista de discussão, que desde o início ironizaram as motivações e meandros do caso, têm acesso rápido ao “arquivo virtual” de lendas urbanas do gênero em suas memórias, sabem também que é muito bem possível tornar um caso gritante de negligência em mais um caso de ostensão. Uma ostensão “original”, aliás - ela própria motivando tantas outras ostensões, mais grosseiras e mais circunstanciais, como vimos -, na medida em que promove uma combinação "nova” de elementos conhecidos. Há, sim, relatos de contaminação em pratos mexicanos (ovos de

\footnotetext{
${ }^{37}$ Mais precisamente, para Fine, o Efeito Golias ocorre quando, por uma “adaptação" da lenda, atribui-se à maior empresa do mercado (no caso, aqui, rede de restaurantes) a responsabilidade pelos danos gerados aos clientes, ampliando-se a repercussão do suposto fato e potencializando-se, assim, o efeito alarmista. Embora não seja esse o caso específico do Wendy’s, aplico aqui a idéia básica do conceito, para fins de argumentação.
} 
barata encontrados em um taco), bem como relatos de dedos encontrados em comida (como o caso do dedo na carne enlatada da marca Menudo, produto também de origem latina!) ${ }^{38}$. Mas dedo no chilli... essa terá sido a primeira vez.

A partir dessa discussão, poderíamos argumentar preliminarmente que, ainda que o caso do dedo no chilli espalhe mais e novos efeitos de insegurança, medo e vulnerabilidade a respeito daquilo que “pomos em nossas bocas” no dia-a-dia incluindo aí, com não menos pertinência, o efeito de culpa(bilidade) atribuível a uma mãe de família que expõe seus filhos a uma refeição arriscada que ela própria, por uma “negligência conveniente”, se dispensa de preparar em casa: uma narrativa também conhecida, como nos lembra Fine (1992: 129) ${ }^{39}$ - tornou-se cada vez mais difícil convencer a todos, todos os momentos e em todos os lugares de que Davi é vítima, se também ele pode ter escondidas “armas ideológico-narrativas de destruição em massa”. E, ademais, não seria mesmo preciso toda uma investigação policial apurada, com sua “narrativa pericial definitiva”, para nos darmos conta disso. Os enredos em que uma falsa vítima lança mão de artimanhas para obter o que deseja nos soam tão ou mais familiares e igualmente persuasivos.

\subsection{Venenos que matam lentamente}

Em novembro de 2006, o IDEC (Instituto Brasileiro de Defesa do Consumidor) notificou quatro das maiores redes de fast-food do país - Burger King, Bob’s, Habib’s e Giraffa’s - para que colocassem informações nutricionais nas embalagens de seus alimentos, ameaçando cobrar a medida na justiça caso elas se recusassem a implantá-la (Gallo 2006). De acordo com o instituto, as empresas descumpriam uma resolução da Agência Nacional de Vigilância Sanitária (Anvisa) e o Código do Consumidor ao não exibirem as informações nutricionais em todos os seus produtos comercializados (em geral sanduíches).

A medida vinha na esteira de uma onda de alerta em relação ao mais novo “vilão” na cruzada pela alimentação saudável, a gordura trans - cuja quantidade, de

\footnotetext{
${ }^{38}$ Outros dois casos "desbancados" pelo site Snopes.

${ }^{39}$ Escreve o sociólogo: "Se essas lendas representam o desejo de uma vida comunitária perdida, a mulher como vítima é simbolicamente adequada. A mulher, ao negligenciar o papel tradicional de quem prepara a comida, ajuda a destruir a família ao permitir a transferência de controle do lar para as corporações amorais e voltadas para o lucro". Em um outro livro, co-escrito com Patricia Turner, o autor chama esse gênero de narrativa de "Grandma’s revenge" ("vingança da vovó") (2001: 84).
} 
acordo com resolução da Anvisa de julho daquele ano, deveria vir especificada na embalagem de todos os produtos comercializados no país. Embora venha sendo usada há muitos anos em boa parte dos produtos de fast-food com os quais estamos acostumados, a gordura trans passou a ser vista como o pior componente que se possa encontrar nos alimentos, seu consumo sendo recomendado a um mínimo diário. De fato, hoje busca-se desesperadamente uma alternativa que lhe seja compatível e viável economicamente ${ }^{40}$.

Mas há um outro vilão que, pelo menos no universo das lendas contemporâneas, tem assustado tanto (ou mais) os consumidores quanto a gordura trans. Trata-se do glutamato de sódio - em inglês, MSG (Monosodium Glutamate) -, aditivo flavorizante encontrado em uma variedade grande de produtos, de salgadinhos industrializados a molhos para saladas e refeições prontas congeladas. A alegação é de que a substância contribui para os crescentes níveis de obesidade mórbida verificados nos Estados Unidos, uma vez que, supostamente viciante, ela induziria os consumidores de tais produtos a comerem cada vez mais. $\mathrm{O}$ alerta se sustenta em parte sobre testes realizados com ratos e ratazanas, nos quais estes ingeriam o glutamato desde o nascimento. Tais testes revelam que o consumo excessivo da substância chega a triplicar a produção de insulina no organismo, fator diretamente relacionado à obesidade.

A questão surge em uma mensagem do grupo de discussão em 26 de fevereiro de 2006, entiluada MSG - Poison in food, em que a leitora Barbara reproduz um longo texto de alerta, misto de artigo (anônimo) e corrente eletrônica - que teria recebido de sua sogra - contra os perigos do glutamato de sódio. O texto traz uma série de referências técnicas, endereços de sites e títulos de artigos científicos que vêm sendo publicados desde a década de 1970 sobre os malefícios provocados pelo consumo excessivo da substância. O governo, as empresas e a própria mídia, cientes da gravidade da situação, estariam jogando o jogo da conveniência, numa espécie de complô silencioso para preservar seus próprios interesses. A questão é tratada aqui em um tom bastante incisivo, apelando para o divulgação o mais ampla possível de seu conteúdo, bem no formato das correntes de Internet. As últimas linhas do texto resumem bem o tom de alerta:

\footnotetext{
${ }^{40}$ Justamente durante o período de escrita desta seção, leio a notícia de que em Nova York será proibido, a partir de julho de 2007, o uso em restaurantes de óleo de frituras que contenham a substância; e a partir de julho de 2008, nenhum alimento vendido na cidade poderá ter gordura trans na receita (Galvão 2006).
} 
We the public, do not want to be rats in one giant experiment and we do not approve of food that makes us into a nation of obese, lethargic, addicted sheep, feeding the food industry's bottom line, while waiting for the heart transplant, diabetic induced amputation, blindness or other obesity induced, life threatening disorders. With your help we can put an end to this poison. Do your part in sending this message out by word of mouth, e-mail or by distribution of this print-out to all your friends all over the world and stop this 'Slow Poisoning of Mankind' by the packaged food industry. Blowing the whistle on MSG is our responsibility, get the word out.

Antes de reproduzir o texto em sua mensagem ao grupo, no entanto, Barbara deixa clara sua desconfiança quanto à veracidade dos fatos ali descritos, afirmando estar certa de que se trata de uma farsa (hoax). Solicita, então, que alguém a ajude a desbancar ou comprovar tais fatos, o que considera bastante improvável (highly unlikely).

A primeira resposta vem de Mark Raftogianis, menos de 24 horas depois. Ele sofre de enxaqueca e afirma que o MSG é comprovadamente um agente desencadeador de sua condição. Demonstra ter pesquisado bastante a respeito, mas, enquanto corrobora a sugestão expressa no texto anterior de que o $M S G$ pode vir disfarçado em diversos produtos supostamente livres da substância, ele não acredita no suposto efeito viciante desta, visto que não encontrou uma só menção ao efeito na bibliografia que leu. Raftogianis prefere acreditar que o alerta exagerado é reflexo de mais uma daquelas histórias que "teóricos da conspiração costumam inventar".

Poucas horas depois, chega a mensagem de Marc Alberts, que discorre sobre o uso milenar e corriqueiro do MSG na culinária oriental, a qual estudou anos atrás. Para os chineses, diz Alberts, a substância não teria a função de mascarar sabores ou de tornar carnes mais tenras, como se poderia acreditar. Ela seria responsável por um sabor pungente que para eles é tão palatável e comum quanto os sabores doces ou salgados. De fato, sendo composto basicamente de água, sódio e glutamato, o MSG estaria presente em praticamente todos os alimentos que contenham proteína. Por fim, Alberts cita uma estatística (e indica uma referência bibliográfica) segundo a qual, nos Estados Unidos, embora cerca de 30\% da população acreditem possuir algum tipo de alergia alimentar, quando testados, apenas $2 \%$ realmente têm compravada a condição.

Um outro Mark (!) se junta, então, à discussão, referindo-se à questão da enxaqueca testemunhada por Raftogianis. Tendo também sofrido de enxaqueca, ele 
afirma ter praticamente se livrado da condição a partir do momento em que remodelou sua cozinha e começou a preparar suas próprias refeições em casa. Acredita que um maior controle sobre sua alimentação - cuja motivação afirma ser anterior ao que identifica atualmente como uma home cooking craze ("nova onda do cozinhar em casa”) - garante a si e a sua esposa (ela, sofrendo do esôfago e se medicando para isso) uma margem razoável de segurança contra tais “irritações”.

O que se pode identificar nesse fio de discussão são pelos menos duas representações recorrentes. Uma é a de que somos vítimas de processos de produção/distribuição que não podemos controlar e que são capazes de nos fragilizar por vício, contaminação ou alergia. Para justificar ou mesmo materializar esse anseio, criam-se e recriam-se vilões, menos ou mais ameaçadores. O da vez é o MSG. Ou a gordura trans... A outra representação é a de que somos culpados pelas escolhas que fazemos sobre aquilo que ingerimos, e que nossas idas cada vez mais freqüentes a restaurantes nos fazem pagar o preço, por mais que exijamos nossos direitos de consumidor à “informação transparente”. A idéia de que haja uma “onda” de cozinhar as próprias refeições em casa (ainda que questionada por algumas mensagens posteriores do thread) gera um efeito discursivo peculiar: sugere uma espécie de "volta mítica”, um retorno a um padrão idealizadamente seguro e artesanal de estar-junto, por mais trabalhoso e "anti-funcional” que isso pareça. Trata-se de uma experiência, algo a ser redescoberto por aqueles que há tempos abandonaram essa espécie de premissa tradicional da vida familiar que se poderia formular com o seguinte enunciado: "Zele pela segurança dos seus; alimente-os bem, como se alimenta a si mesmo”. Trata-se, como diria Maffesoli (2004/2007), de uma experiência ancestral dinamicamente enraizada, uma experiência de empatia mística entre o homem e o seu ambiente cotidiano.

\section{3. "Leptospirose em Latinha” 41 , ou Uma História Exemplar}

Em junho de 2003, tendo acabado de ingressar no programa de doutorado, recebi de minha orientadora um e-mail contendo a seguinte mensagem de alerta, que lhe fora encaminhada por um conhecido $^{42}$ :

\footnotetext{
${ }^{41}$ Título emprestado de uma página na Internet em que a referida lenda é discutida, no endereço: http://cudebebado.cabaretvoltaire.com/index.php?LeptospiroseEmLatinha.

${ }^{42}$ Reproduzo a mensagem no formato original, incluindo os erros de coesão textual e pontuação.
} 


\section{Assunto: ENC: En: Alerta!}

>>Geralmente esses avisos são inventados, mas ele tem sentido.

>>ALERTA GERAL

>>Repasse a todos da sua lista !!!

>> Morreu; Orlando, brilhante advogado e pai da modelo Daniela Sarahyba, numa situação absolutamente igual a anterior.

>> Ele tinha uma casa e uma lancha em Angra. Ao sair na lancha com amigos, num domingo, levou na geladeira da embarcação latas de cerveja e refrigerantes.

$>>$ No dia seguinte, 2a. feira, estava internado numa UTI e morto na 4a. feira.

$>>$ Ele era um atleta, adorava a vida, que a vivia com intensidade.

>> O exame cadavérico atestou leptospirose fulminante contraída na lata de cerveja que ele havia tomado, sem copo e sem canudo, no barco.

>> O exame das latas atestou que estavam infestadas de urina de ratos, conseqüentemente de leptóspiras.

$>>$ MUITO CUIDADO !!!

$>>$ AVISO AOS CONSUMIDORES DE BEBIDAS EM LATA:

>> Toda vez que comprar uma lata de refrigerante, tome cuidado de lavar a parte de cima com água corrente e sabão, se possível, use canudo.

>> Aqui em casa, é obrigatório lavar as latas com desinfetantes mesmo as que vão à geladeira.

>> Uma amiga da família morreu depois de beber uma soda em lata. Provavelmente ela não limpou a parte superior da lata antes de beber, e a lata estava suja com urina de rato seca, que contém substâncias tóxicas e letais, inclusive leptóspiras, causadoras da leptospirose.

>> Bebidas em lata e outros alimentos enlatados ficam guardados em armazéns que geralmente estão infestados de roedores, e posteriormente são transportados para as lojas de venda sem a devida limpeza.

>> Complementando: Uma pesquisa do INMETRO confirmou que a tampa da latinha do refrigerante é mais poluída que um banheiro público.

>>Segundo essa pesquisa, a quantidade de vermes e bactérias era tão intensa que eles sugeriam que se lavasse a tampa da latinha com água e sabão".

$>>$ Dr. Fabio Lopes Olivares

$>>$ Setor de Citologia Vegetal

>> Laboratório de Biologia Celular e Tecidual (LBCT)

$>>$ Centro de Biociências e Biotecnologia (CBB)

>> Universidade Estadual do Norte Fluminense (UENF)

$>>$ Av. Alberto Lamego, 2000 - Horto 28015-620 - Campos dos

$>>$ Goytacazes $(\mathrm{RJ})$

>> Tel: (24) 726.3838 / Tel(fax): (24) 726.3714

>> Por favor, encaminhe este aviso às pessoas com quem você se preocupa. 
O enunciado que abre a mensagem - "Geralmente esses avisos são inventados, mas ele tem sentido” - prenuncia que estamos diante de uma lenda urbana. E já convida a pensar: por que esse aviso tem sentido? O que significa, aqui, ter sentido? Responder essa pergunta implica analisar como se constrói ao longo do texto uma narrativa de verossimilhança. "Morreu; Orlando, brilhante advogado e pai da modelo Daniela Sarahyba, numa situação absolutamente igual a anterior”. Ora, não ficamos sabendo em nenhum momento a que situação anterior o caso de Orlando se refere - nós, leitores na rede de comunicação na qual essa mensagem se apresenta como um elo. O que terá acontecido antes? Não sabemos também quando morreu Orlando, embora um conhecimento mínimo das regras implícitas de um texto jornalístico nos remeteria ao tempo absolutamente recente: “Morreu Orlando”, verbo pré-posto ao sujeito. Quer dizer, se a mensagem é um alerta mas também uma notícia, então devemos entender que Orlando morreu hoje, ontem, ou por esses dias. Devemos saber também quem é a modelo Daniela Sarahyba. Para alguns, Daniela pode ser uma “celebridade” tão reconhecível quanto tantas outras em exposição regular na mídia. Estaria aí já parte do alicerce da verossimilhança narrativa? Acredito que sim. A menção a um episódio envolvendo uma pessoa famosa - no caso, seu pai - confere uma certa credibilidade ao relato, que só irá se reforçar, certamente, com a descrição das circunstâncias em que se deram a morte. Mas há também outros elementos de autenticação da história que concorrem para criar um efeito de transparência de sentido. Um deles é a menção a uma suposta pesquisa do Inmetro, que corroboraria a tese de que latinhas de refrigerante são mais contaminadas que vasos sanitários em banheiros públicos. Além disso, há também a referência a uma “amiga da família”, que teria morrido em circunstâncias semelhantes - embora não fique claro de que família se trata: a de quem escreveu a mensagem? E finalmente, um elemento fundamental é a “assinatura” do texto, atribuída a um profissional de uma “Universidade Carioca”, acompanhada de dados para contato.

Até aí a mensagem não se distingue muito de vários outros alertas de saúde pública, dentre os quais podemos citar, de momento, o da infecção por agulhas contaminadas por HIV em locais públicos (ver Capítulo 5 a seguir) e o do uso de desodorantes antitranspirantes que provocam câncer de mama. Mas a história prossegue. Exatos dois anos e meio depois, em dezembro de 2005, um colega de pós-graduação (na época cursando o Mestrado), sabendo do meu interesse pelo tema, me envia uma mensagem que, para minha surpresa, reproduz o conteúdo praticamente inalterado! 
Desta vez, o enunciado de abertura é substituído por "Estou retransmitindo por achar importante. Leiam com atenção”, o que sinaliza uma adesão menos hesitante à plausibilidade do relato. Outra diferença relevante se refere à pressuposta cadeia de eventos similares, anteriormente relatados. Mais “didático” e ao mesmo tempo mais emocional, o enunciado aqui se lê: "Morreu Orlando. Brilhante advogado e pai da modelo Daniela Sarahyba, numa situação absolutamente igual ao que se vem repetindo, com freqüência dolorosa”. O apagamento da referência pressuposta na mensagem anterior contribui aqui para um efeito maior ainda de novidade. É como se o texto viesse chamar a atenção, "pela primeira vez”, para um fato ao qual todos nós interlocutores estamos sujeitos e para o qual precisamos todos estar alertas. O restante do texto permanece o mesmo, palavra por palavra. Orlando não morreu duas vezes, é claro. Mas o alerta permanece.

Movido pela curiosidade cercando o caso, conduzi uma pesquisa na Internet que me traria mais surpresas. A enciclopédia virtual Wikipedia, em uma breve entrada sobre a modelo, traz como única informação pessoal (além do local de nascimento e o nome da mãe) algo que o leitor da mensagem não teria como suspeitar. O pai de Daniela morrera, sim, de leptospirose, mas em 1994, quando a modelo tinha apenas 10 anos de idade! O esboço de biografia acrescenta que a modelo começou a trabalhar por causa das dificuldades financeiras que a família enfrentou após a morte de Orlando. E conclui: "Uma lenda urbana afirma que ele contraiu a doença ao beber cerveja de uma lata contaminada com urina de rato, mas acredita-se que ele tinha na época um ferimento no pé e teve contato com água contaminada”.

Como se a fonte não fosse confiável o bastante, prossegui em minha pesquisa e encontrei uma entrevista com a modelo, concedida a Juliana Lopes e publicada na revista IstoÉ Gente em outubro de 2001 sob a chamada “Tive de crescer na marra”. As primeiras perguntas abordam precisamente a morte do pai, as circunstâncias em que ocorreram e as dificuldades que a menina teve de enfrentar. Num tom emocionado ("Daniela respira fundo e chora"), a modelo confirma que o pai morrera muito rapidamente, praticamente uma semana depois de estar com ele na viagem de barco. Lembra-se de não ter entendido muito bem o que ocorrera então, e que mandava cartas para seu pai no hospital acreditando estar tudo bem. A questão da lenda urbana em torno do ocorrido, no entanto, não é mencionada em nenhum momento da entrevista. 
Mas o mais surpreendente eu ainda estava por descobrir. Lendo mais tarde um artigo sobre rumores eletrônicos, de autoria do pesquisador em sociologia Florian Dauphin e publicado na revista francesa Sociétés em 2002, descubro que a mesma lenda, com texto praticamente inalterado, circula desde 1998 nos Estados Unidos e foi adaptada para o francês em setembro de 2001. O texto atribui como fonte um site de

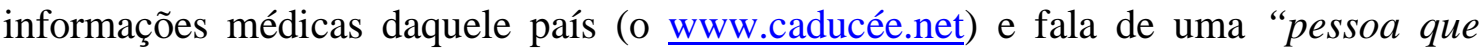
morreu recentemente em circunstâncias absurdas" (Dauphin 2002: 83). A “amiga da família”, citada nas versões em português, desaparece aqui, e é àquela tal pessoa mesma que se atribui o provável “descuido” de não limpar a parte superior da latinha. Também estão ausentes a assinatura e os dados de contato do suposto autor da mensagem. Ainda, curiosamente, o Inmetro (com esse nome mesmo) é citado aqui como sendo um órgão regulador da Espanha, e não do Brasil!

Minha pesquisa desemboca, enfim, no site brasileiro Quatro Cantos, o qual, tivesse eu consultado na ocasião em que recebi a primeira mensagem, teria certamente “estragado" o intrigante percurso de descobertas que trilhei muito depois. Lá se encontra um histórico de toda a evolução do relato, incluindo um menção à versão francesa e aos desmentidos que tiveram de ser feitos, de várias partes envolvidas dentre os quais, o do Inmetro brasileiro; o da Associação Brasileira do Alumínio (ABAL); e o do próprio médico brasileiro (Dr. Olivares) que nega ter escrito o relato, mas que admite simplesmente ter "repassado" a mensagem.

De qualquer maneira, a narrativa da leptospirose na latinha me faz retomar um dos argumentos centrais de minha tese. Entre o "pode acontecer com qualquer um de nós” (estrutura projetada pelo acontecimento) e o "aconteceu com alguém conhecido, em pleno vigor físico e alegria de viver” (estrutura deslocada pelo acontecimento), retece-se uma narrativa de alerta que há quase uma década vem circulando em caixas de correio eletrônico ao redor do mundo, renovando a idéia de que estamos cercados de perigos invisíveis, perigos microscópicos que nos podem ceifar a vida quando menos imaginamos. Como, por exemplo, os perigos de um simples passeio de férias, cujo maior propósito seria o de fugir da rotina, estresse e preocupações do dia-a-dia, mas cuja experiência evoca uma “moral exemplar” que poderíamos resumir no seguinte enunciado: "Estejamos alertas, pois nunca estamos completamente seguros em nossa vida cotidiana, nem menos quando nos damos o luxo de aproveitar a vida bebendo uma cerveja entre amigos”. 


\section{Shop 'til you drop... dead ${ }^{43}$}

Verdadeiros templos de consumo das cidades modernas em todo o mundo, os shopping centers e hipermercados, com seus gigantescos estacionamentos, estão longe de representarem o paraíso seguro e asséptico dos cidadãos-compradores... pelo menos no universo das lendas urbanas. Relatos envolvendo desde incidentes desagradáveis até assaltos, seqüestros e assassinatos que se desenrolam nesse tipo de local são documentados desde as primeiras coletâneas de lendas organizadas nos Estados Unidos pelo folclorista Jan Harold Brunvand (1981; 1999; 2000; 2001) e em estudos citados por autores como Gary Alan Fine (1992) e Bill Ellis (2001). Na nossa lista virtual, não é diferente. Foram várias foram as notícias de jornais que, publicadas ao longo de 2005 e 2006, mereceram menções dos participantes, ainda que não suscitassem threads de discussão. Nesta seção, discuto dois desses textos procurando identificar neles elementos que concorrem para fortalecer o processo discursivo de “cotidianização" das histórias em torno do tema.

O primeiro texto é uma mensagem intitulada Another anymall kidnapping scheme (“Outro golpe de seqüestro em um shopping qualquer”), enviada por Terri Valentin em 26 de fevereiro de 2005. Trata-se de uma mensagem de alerta, repleta de referências vagas, a respeito de uma mulher que, aproximadamente um mês antes, ficara na porta de um shopping center distribuindo um folheto com o intuito de prevenir os freqüentadores do local sobre uma modalidade de assalto que ela havia sofrido no dia anterior. Tendo terminado suas compras e se dirigido ao estacionamento onde havia deixado seu carro, a mulher se deparou com um pneu furado, ao qual pôs-se a trocar. Nesse momento um homem vestindo um terno e portando uma maleta apareceu oferecendo ajuda, que ela aceitou. Após trocar o pneu, o homem pediu à mulher que lhe desse uma carona até o local onde ele havia estacionado o seu carro, do outro lado do shopping, alegando ter se confundido, ao sair por uma porta errada, e estar atrasado para um compromisso. A mulher, embora um pouco apreensiva, concordou em retribuir o favor. Porém, como havia notado que o homem fechara sua maleta no porta-malas do carro dela logo após guardar o equipamento, resolveu agir prudentemente e inventou a desculpa de que precisava retornar ao shopping para comprar um último item de que se

\footnotetext{
${ }^{43}$ Referência à expressão inglesa "Shop 'til you drop", literalmente: “Compre até cair” Aqui, no caso, "cair morto".
} 
lembrara, pedindo que ele ficasse esperando por alguns instantes. De volta ao shopping, a mulher correu a avisar um segurança, que retornou com ela ao local de onde o homem suspeito havia, então, desaparecido. Abriram o porta-malas, tiraram de lá a maleta, que estava trancada, e a levaram à delegacia de polícia. Lá revelou-se finalmente a trama: a maleta continha facas, corda e fita isolante... e não havia nada de errado com o pneu (só havia sido esvaziado). Ficava claro, assim, que se tratara de um golpe, do qual a vítima escapara com muita sorte.

A mensagem termina com um apelo veemente, bem ao estilo das correntes de alerta:

$>$ I'd like you to forward this to all the women you know. It may save a life.

$>$ A candle is not dimmed by lighting another candle. I was going to send this to the ladies only; but guys, if you love your mothers, wives, sisters, daughters, etc., you may want to pass it on to them, as well.

$>$ Send this to any woman you know that may need to be reminded that the world we live in has a lot of crazies in it.... better safe than sorry.

$>$ PLEASE BE SAFE AND NOT SORRY! JUST A WARNING TO ALWAYS BE ALERT AND USE YOUR HEAD!!!

“Uma vela não se apaga ao acender outra vela”. Mais uma vez está presente aqui a idéia de que não custa nada repassar a mensagem, por preocupação. Afinal, estamos todos - como mães/pais, esposas/maridos, irmãs/irmãos, filhas/filhos - sujeitos a ocorrências semelhantes... “se não usarmos a cabeça!”. De fato, podemos observar como o discurso é construído visando a uma atitude responsiva, o mais ampla possível, de seu público virtual. Suas generalizações e ausência quase total de referências factuais convergem para criar um efeito de inclusão numa rede de suspeitas e perigos dos quais quase ninguém pode escapar. No final, não importa exatamente em que shopping, quando e com quem ocorreu o golpe; importa é que ele poderia muito bem ter ocorrido com qualquer um(a) de nós.

O segundo texto traz um link, enviado por Brian Chapman, para um artigo de Melissa Leong publicado no jornal canadense National Post em 2 de dezembro de 2005 com o título "Hoax E-mail Makes Toronto Women Fearful”. O artigo começa com uma descrição um tanto genérica: uma mulher chamada Lea Greenwood (sem mais detalhes) havia recebido recentemente um e-mail alertando-a sobre o ritual de iniciação de uma gangue em Ontário em que homens se infiltravam nos bancos traseiros dos carros de mulheres para seqüestrá-las. Na seqüência, o artigo descreve o conteúdo do e-mail, ora 
citando-o diretamente ("'This is not a joke.... Please read and pass on to other women who drive around on their own") ora recontando-o ("It told of a gang initiation practice, in which...”). Segundo a mensagem, o ritual consistia na tarefa de trazer para o grupo uma mulher e/ou seu carro. E uma das maneiras de se fazer isso era entrar sorrateiramente nos veículos enquanto essas mulheres estavam abastecendo em postos de gasolina ou fazendo compras em supermercados. No final da mensagem, lê-se a assinatura de Barbara Baker, secretária do diretorado de polícia, à qual Greenwood, antes de retransmitir o texto, acrescentou sua própria assinatura, além de dados para contato. Mais significativamente: Greenwood usou sua assinatura profissional, que indicava a posição e a organização para a qual trabalhava: a Sexual Exploitation Education and Awareness Coalition of Toronto.

Só então, com a "história contada”, ficamos sabendo quem é Lea Greenwood, “responsável involuntária” por uma onda de alarmismo que, segundo o artigo, se desencadeou menos de 24 horas depois. Ligações desesperadas começaram a chegar a seu escritório e a seu telefone celular, incluindo uma mulher em pânico temendo por sua vida e um policial conhecedor de lendas urbanas. Nos dias seguintes, ficou sabendo que a mensagem, contendo sua assinatura, havia se espalhado largamente, o que pôde comprovar numa conversa, poucos dias depois, com uma amiga em um escritório de advocacia, a quem a mensagem havia sido enviada após seis encaminhamentos (ela sendo o sétimo grau de separação!). O que levou Greenwood a enviar várias outras mensagens contendo o esclarecimento. O artigo conclui citando-a: "It's a lesson about the power of the Internet”, mas, antes disso, somos informados da motivação inicial que a fez enviar a mensagem original a seu clube de leitura: "I was thinking: We're all out and about, we do other late-night things, we've got kids." Como mulher, mulher com filhos, mulher independente que sai à noite, e mulher ativista em uma organização dedicada à educação e conscientização a respeito da exploração sexual feminina, pouco nos espantaria - ou talvez justamente por esse último detalhe nos espantaria, sim! - se Greenwood fizesse outra coisa senão assinar embaixo e re-lançar a narrativa diretamente para dentro de um ávido ciberespaço. Lá, ela irá se juntar a tantas outras narrativas "institucionais” e bem-intencionadas, mas (a meu ver) igualmente alarmistas, tais como o autêntico "guia de segurança” para mulheres veiculado pelo site filantrópico www.thenonprofits.com com o título “Tips for Staying Safe... for Women”. Dentre as inúmeras recomendações, encontramos: Quando parar o carro em um estacionamento 
ou garagem, observe os carros estacionados à sua direita e à sua esquerda. Se um homem estiver sentado sozinho no veículo, caminhe de volta ao shopping (ou local de trabalho) e peça para um segurança ou policial acompanhá-la de volta. "IT IS ALWAYS BETTER TO BE SAFE THAN SORRY. (Better paranoid than dead.)”.

Obviamente, como já poderíamos imaginar a essa altura, as duas mensagens selecionadas não nos contam "histórias novas”. Ellis (2001: 48) relata que desde pelo menos o final da década de 1970 circulam histórias de supostos rituais de iniciação de gangues operando em estacionamentos de shopping centers, onde se escondem sob carros esperando para navalhar os tendões do calcanhar de moças e então estuprá-las. Observa-se, de fato, um ciclo de histórias que, com variações mais ou menos cruéis como aquela em que membros da gangue seguem a vítima até o provador de roupas da loja, onde decepam-lhe os dedos para lhes roubar anéis valiosos - , tornaram-se populares ao longo dos anos 1980 e 1990 e, pelo visto, estão longe de desaparecer. Em muitos casos, acrescenta-se o elemento conspiratório segundo o qual a polícia e os lojistas dos centros comerciais agem em conluio para evitar que os relatos cheguem à mídia e comprometam os negócios. Como bem lembram Whatley e Henken, as pessoas podem até eventualmente se dar conta de que tais narrativas são “apenas lendas”. Entretanto, “isso não diminui a força da mensagem de alerta, uma vez que mulheres olham cuidadosamente à distância por baixo de seus carros antes de se aproximar e checam o assento de trás antes de entrar” (2001: 4). E provavelmente continuarão a fazê-lo.

Em um artigo em que analiso uma outra mensagem de alerta - relatando o caso de um adolescente de classe média que, passando em frente a uma construção, é atraído por um choro de bebê vindo de trás de uma caçamba de lixo, apenas para se tornar vítima de um seqüestro-relâmpago do qual, mediante pagamento de resgate, ainda retorna infectado com “várias doenças” -, traço uma reflexão que, ao meu ver, aplica-se igualmente aqui. Ela tem a ver com o efeito de cotidianidade que mensagens desse tipo contribuem para construir. Partindo de uma visão dialógica da linguagem proposta por Bakhtin (1934-5/1990; 1952-3/2000), segundo a qual cada enunciado/obra é entendido como uma resposta a outras enunciados/obras de um fluxo verbal ao mesmo tempo em que suscita uma atitude responsiva por parte dos interlocutores com que irá interagir, proponho olhar para a mensagem de alerta como se inscrevendo num fluxo permanente de outras mensagens, outros discursos que já nos alertaram antes sobre outros perigos, 
mais ou menos plausíveis, mas que "contribuíram para a construção de um efeito urgente e cumulativo de realidade social, uma espécie de cultura do medo que se alimenta de fatos mas também de narrativas como essa, num processo dialético de significação” (Lopes 2005: 44-5).

O trabalho sobre as redes de memória operado por esse fluxo permanente (e cotidiano) de mensagens concorre para a naturalização de uma "rotina" sempre presente e sempre potencialmente ameaçadora: a dos seqüestros relâmpagos, dos golpes em estacionamentos, da violência gratuita, dos crimes banais e afins. Ele contribui, por assim dizer, para um "efeito impregnante de cotidianidade”, ou um “apagamento da história”, ao mesmo tempo em que, de um modo só aparentemente paradoxal, insere seus interlocutores numa rede de reconhecimento e aceitação que constitui o próprio material de que o cotidiano é feito.

Mas há de se recuperar a especificidade do fato de que os relatos que abordamos nesta seção transcorrem em locais de consumo, dentro e (particularmente) fora de suas dependências. Que fique claro: não estamos tratando simplesmente de ameaças a mulheres, alvos supostamente mais frágeis da insegurança e violência urbanas que, atingem, afinal de contas, todo o tipo de local público. É importante ressaltar que essas narrativas dizem respeito também ao universo consumista, conta-nos histórias de cidadãos consumidores. Os locais em que esses cidadãos fazem suas compras diárias, freqüentemente acompanhados de suas famílias - são várias as lendas que figuram crianças como vítimas também, como veremos no Capítulo 6, seção 3 - , demonstram ser espaços tão ameaçadores quanto os cruzamentos de avenidas perigosas ou as ruas mal-iluminadas de algum reduto da grande cidade. Os shopping centers e hipermercados, com seu ambiente climatizado e confortável, são também, não nos esqueçamos, o ambiente por excelência impessoal e serializado das sociedades de consumo $^{44}$. São símbolos bastante auspiciosos de uma globalização em que cada vez mais ter uma identidade significa - conforme apontam, entre outros, Bauman (2003; 2004) e Lipovetsky (2004) - encontrar o seu lugar em um universo cada vez mais (angustiantemente) variado de opções efêmeras de consumo cujos estoques são

\footnotetext{
${ }^{44}$ Em seu livro Fast Food Nation, Eric Schlosser descreve o paradigma: “O pensamento básico por trás do fast food tornou-se o sistema operacional da economia de comércio varejista nos dias de hoje, dizimando os pequenos negócios, obliterando diferenças regionais e espalhando lojas idênticas por todo o país como um código auto-replicante" (Schlosser 2002: 5)
} 
rapidamente renováveis. Enfim, para quem pode consumir, os shoppings e hipermercados são locais que estamos “condenados” a freqüentar.

Olhando retrospectivamente para o conjunto de temas discutidos neste capítulo, poderíamos nos perguntar de que maneira aqueles objetos e locais que nos cercam, destinados ao consumo e ao prazer do consumidor livre - a lembrar: os aparelhos celulares, as comidas prontas, os shopping centers -, podem gerar sentimentos tão ambivalentes. A resposta, curta ou longa, teria necessariamente de passar pela questão da narrativa. Precisamos de narrativas que elaborem simbolicamente as ambivalências que tais elementos do mundo moderno geram em nós. Mas ao mesmo tempo alimentamos com essas narrativas uma sensação cada vez mais difusa de ansiedade e temor, uma espécie de "realidade” só tornada possível pela “ficção”. A percepção crítica sobre as ambivalências experimentadas por indivíduos nas práticas sociais do cotidiano, inclusive a própria prática de contar histórias, é o que nos irá permitir ler agora, sob um prisma bastante particular, a "prosaica” e triste conclusão a que chega o guia de segurança para mulheres mencionado anteriormente: “Nosso mundo não é tão seguro quanto pretendemos que seja, e viver em nossos mundos de fantasia IRÁ nos meter em encrenca, mais cedo ou mais tarde. (...) Todos nós precisamos escutar isso.” Bem, assim, pelo menos, reza a lenda... 


\section{CAPÍTULO 5: Lendas Urbanas em Arquivo: entre o velho e o novo}

"Legends may die away shortly, but they may also linger on and enter a period of latency, losing their momentary attraction only to come back again unchanged, modified, or expanded."

- Linda Dégh, Legend and Belief, 2001

"There is no FAQ or archives [on this list]. David (AKA [the creator of] snopes) once said (when he used to post here) that having these would hinder us from re-hashing the same old stuff again and again, year after year.” -Paul Bowers, urban-legends@yahoogroups.com, 2005

Algumas lendas urbanas se tornam clássicos do gênero pelo modo como ressurgem em ciclos, mantendo um motivo comum, mais ou menos invariável, e adaptando-se aos temas locais e ao momento social em que circulam. É o caso da história envolvendo o ataque à freqüentadora do shopping center analisada no capítulo anterior. Uma pesquisa um pouco mais detalhada nos daria conta de relatos bastante semelhantes a esse tendo ocorrido ainda na década de 1980. Muitas são, de fato, as narrativas que se desenrolam em ciclos. A cada retomada, a cada novo sopro de vida, desencadeiam-se aqueles velhos e mesmos efeitos de pânico e alarmismo, para, logo em seguida, vir o desmentido, ou, como se diz em inglês, debunking (desbancamento).

Neste capítulo examino três desses ciclos que, um tanto já conhecidos principalmente por usuários freqüentes da Internet, insistem em reaparecer em nosso corpus, desde 2005 até a data desta escrita. Mas antes gostaria de retomar um conceito que foi referido brevemente em discussões anteriores e que julgo merecer maior desenvolvimento em conexão com o foco que terá a presente discussão. Trata-se da noção de arquivo.

Segundo Foucault, o conceito de arquivo se relaciona ao domínio dos enunciados que é articulado por um a priori histórico. Tal domínio se apresenta como um volume complexo em que se diferenciam regiões heterogêneas e em que se instauram práticas discursivas onde vão se dar os enunciados como acontecimentos. $\mathrm{O}$ que Foucault propõe que chamemos de arquivo é precisamente o conjunto desses sistemas de enunciados. Para o autor, o arquivo funciona como a lei que rege o que pode ser dito, isto é, o aparecimento dos enunciados como acontecimentos singulares. Ele é o que define, enfim, a própria condição de enunciabilidade. Estruturando-se 
permanentemente entre o esquecimento e a tradição (ou a memória discursiva), o arquivo "faz aparecerem as regras de uma prática que permite aos enunciados subsistirem e, ao mesmo tempo, se modificarem regularmente” (1969/2004: 147-8).

Falar de um arquivo de lendas urbanas implica considerar esse movimento entre esquecimento e memória que se encontra na base da constituição de um sistema de enunciados. O que permite que lendas envolvendo alarmismos tecnológicos e/ou alimentares (para nos ater aos exemplos já aqui analisados) sejam reconduzidas e incorporadas a um repertório sempre atualizado e em circulação é justamente o fato de essas narrativas se situarem entre uma tradição - o arquivo potencialmente solidificado (em memória oral ou documentado em coletâneas) de lendas urbanas - e um esquecimento - o efeito de reaparecimento "fresco" e renovado de antigas tramas sob a forma de novas. O constante reaparecimento de tais lendas é possível, a princípio, por referência a esse próprio sistema anônimo, esse arquivo imaginável de lendas que constituem a condição de sua enunciabilidade; mas é possível também, é claro, pelas próprias condições sócio-históricas de produção - ou o que Dominique Maingueneau chama de "redes institucionais" (1984/2005: 23) - que sustentam e ao mesmo tempo tornam possível a enunciação de tais narrativas. Assim, por exemplo, as novas modalidades tecnológicas surgidas e as novas “ameaças” que essas representam em um momento inicial, ou as inovações e transformações constantes no mercado alimentício e nos hábitos alimentares das pessoas, são todos elementos que irão se incorporar à trama perenemente em construção do arquivo de lendas urbanas.

A noção de que o arquivo é estruturado entre o esquecimento e a tradição encontra eco na proposição de Derrida, já mencionada anteriormente (ver Capítulo 1, seção 1.3), segundo a qual o arquivo é a um só tempo instituidor e conservador, revolucionário e tradicional. $\mathrm{O}$ arquivo acumula e faz acumular, reserva e faz reservar; isto é, cria uma lei que se deve respeitar por força do próprio processo de sua construção. Discutindo o modo como a psicanálise freudiana pensou a questão do arquivo, Derrida aponta para as tensões, contradições ou aporias que são implicadas pela pulsão de morte que subjaz o desejo de arquivamento (ou mal de arquivo). Sim, pois arquivar envolve não uma operação natural, mas uma operação de investimento do desejo, uma projeção. Ele se apresenta mesmo como "um movimento de promessa ou de futuro não menos que de registro do passado” (Derrida 1995/2001: 44). Articula, enfim, o saber e a memória à promessa de um devir. 
Assim é que se poderia afirmar que o arquivo de lendas urbanas existe, em princípio, como a projeção de um desejo de arquivamento - desejo esse cujo desdobramento vem impresso na língua e no discurso, e, vale dizer, nas narrativas mobilizadas pela cultura. Tal desejo não se reduz apenas ao esforço material de coleção, documentação e registro de narrativas sob os mais específicos critérios de classificação histórica. Esse investimento existe, é claro, como um aspecto considerável da questão. Mas há, além disso e, fundamentalmente, o trabalho exercido no interior das práticas discursivas, o qual remodela e reconfigura constantemente os documentos do arquivo, ora trazendo à luz seus traços de permanência - os efeitos de afiliação, de conservação, de tradição e "registro do passado" -, ora sua promessa de novidade, seu impulso instaurador, sua enunciação inescapavelmente contingente.

$\mathrm{O}$ arquivo torna-se, de qualquer maneira, um pressuposto para a circulação de qualquer forma de discurso e de saber. Como afirma Elisabeth Roudinesco, ele é a própria condição da história. Está situado entre os limites impossíveis de uma mesma interdição: aquele que por um lado afirma seu excesso - isto é, que lhe confere a autoridade máxima do arquivamento de um saber absoluto, “espelho de si” tendendo à anulação da história como construção interpretativa - e aquele que, por outro, nega seu peso pela força de uma memória subjetiva - isto é, que tende à soberania delirante de um eu que o reinventa "livremente”. O arquivo é, assim, esse vestígio não apagado (ou espectro) sem o qual nenhuma narrativa pode começar, em primeiro lugar, a ser contada e interpretada como tal (Roudinesco 2001/2006: 9-10).

Como corolário desse pensamento, poderíamos afirmar que o arquivo é condição de existência dos próprios gêneros discursivos. E são várias as conexões que se podem traçar a partir dessa afirmação. No caso das narrativas que estou analisando, reconheço, como intérprete, que estou diante de um texto “pertencente” ao gênero lenda urbana quando recupero-o num arquivo, isto é, identifico-o como tal por fazer parte de um arquivo já constituído de narrativas afins, especificamente aqui a lista de discussão na Internet sob a rubrica [UL] (urban legends). Quer dizer, o arquivo está “pronto”, chancelado por uma ordem classificatória, uma tópica comum e agregadora. Mas nesse mesmo movimento, e a um só tempo, instauro a lei do que será considerado lenda urbana quando seleciono os textos para o meu corpus, quando excluo outros textos, quando decido, enfim, o que se encaixa e o que não se encaixa no arquivo, operando 
dessa forma uma nova reconfiguração, um deslocamento no interior de um arquivo supostamente dado.

Também é possível propor que os ciclos de lendas urbanas que vêm e vão, que são esquecidos e depois retomados, são modos concretos de construção de um arquivo historicamente lançado. Eles são articulações sempre renovadas de vestígios imemoriais - vestígios da doença, da insegurança, do medo da morte, da ambição, do poder, e outras experiências humanas que impulsionam a narração de histórias, sejam elas "reais ou fictícias”.

Mas voltemos já ao "nosso" arquivo e passemos ao estudo do primeiro dos ciclos selecionados para este capítulo. Vejamos logo como essas histórias são (ou podem ser) contadas.

\section{The Nigerian Scam - Um golpe sem fronteiras}

Alguém lhe envia um e-mail propondo que você seja o beneficiário de uma considerável soma em dinheiro (dólares) em troca de tornar disponível sua conta bancária a fim de que nela seja depositada uma herança ou os rendimentos de uma grande operação financeira cujos verdadeiros beneficiários - em geral milionários ou pessoas importantes - se encontram sob alguma restrição legal ou de outra natureza para reclamar a quantia. Você aceita, mas não consegue um centavo do dinheiro prometido; ao contrário, tem de pagar pequenas taxas para manter as negociações e solucionar desembaraços legais e outros impedimentos que podem ir se tornando cada vez mais complicados. Nessas linhas gerais poderia ser descrito um golpe internacional que circula hoje em dia por correio eletrônico - e décadas (e séculos!) atrás por carta, em diferentes versões - e cuja configuração mais difundida se costuma denominar Nigerian Scam (golpe nigeriano), ou 419 Scam (referência ao número do artigo da constituição nigeriana que aborda esse tipo de fraude).

Em abril de 2003, tive meu primeiro contato com esse tipo de golpe. Foi-me encaminhada por e-mail, de uma colega que sabia do meu interesse em lendas urbanas, uma mensagem que ela havia recebido contendo a seguinte proposta de negócio, 
“urgente e confidencial ${ }^{45 ”: ~ a ~ S e n h o r a ~ M a r i a m ~ A b a c h a, ~ v i u ́ v a ~ d o ~ e x-c h e f e ~ d e ~ e s t a d o ~}$ nigeriano General Sani Abacha, relata que após a morte misteriosa do marido por ataque do coração foi comunicada pelo advogado da família, Bello Gambari, que o General mantinha guardadas em segredo quatro caixas de metal contendo cinco milhões de dólares cada uma - dinheiro destinado a investimentos pessoais em contas bancárias fora do país. Desde a morte do General, a família estaria sendo perseguida por autoridades do governo nigeriano, que teriam detido para investigação seu filho mais velho, Mohammed, e bloqueado as contas da família no país, além de terem confiscado aplicações vultosas em contas na Suíça (no valor de 20 milhões de dólares) e Alemanha (120 milhões de marcos). Após o enterro do General, prossegue Abacha, o Sr. Gambari teria encontrado o nome e endereço do destinatário da presente mensagem em uma publicação de uma agência do governo voltada para a promoção de oportunidades de negócios, o que a teria motivado a lhe escrever propondo a operação. O destinatário em questão disponibilizaria sua conta bancária para que o dinheiro - que a essa altura já havia sido transferido para um país vizinho (Accra-Ghana) com a ajuda de um alto oficial do governo local - pudesse nela ser depositado, com a garantia de participação em parte do montante a combinar entre as partes. A Sra. Abacha encerra a mensagem reforçando a solicitação de absoluto sigilo sobre a proposta (dadas as circunstâncias políticas delicadas em que a família se encontrava na Nigéria) e oferecendo os dados de contato do advogado para o eventual prosseguimento das negociações.

Um levantamento posterior em sites e artigos publicados na Internet sobre o tema revelariam ser essa uma das várias versões disponíveis do Nigerian Scam, em que basicamente só os personagens principais mudavam. Em algumas versões, as mensagens traziam membros de igreja e instituições como possíveis beneficiários. Em outras, o país de onde deve vir o dinheiro é a Serra Leoa ou a Costa do Marfim, em vez da Nigéria. E em ainda outras, os solicitantes são oficiais do governo, bancos ou organizações não-governamentais. A versão que recebi, no entanto, ficou lá, arquivada, sem se “comunicar” com outros textos.

Dois meses depois (junho de 2003), recebi diretamente como destinatário - e não como pesquisador do assunto - uma outra mensagem supostamente vindo da

\footnotetext{
${ }^{45}$ Ver APÊNDICE B para o texto original completo.
} 
África, desta vez do Zimbabwe ${ }^{46}$. O autor, Richard Mbeki, se apresenta como filho do finado Sr. James Mbeki, um fazendeiro branco daquele país. E justifica o envio do e-mail pela necessidade de buscar um parceiro de negócios em um país estrangeiro, dada a instabilidade política que vive o Zimbabwe sob o governo de Robert Mugabe. Em um decreto em maio de 2001, o presidente ordenou a ocupação e confisco de bens de mais de 6000 fazendas de proprietários brancos - mais de 500 dos quais teriam sido assassinados, segundo reportagens da CNN e outros órgãos da mídia internacional -, o que tornou a segurança para investimentos financeiros desse setor altamente comprometida. Não tendo outro lugar para ir, e impossibilitado de localizar parentes distantes, Mbeki afirma ter encontrado o nome do destinatário - o meu, no caso - por intermédio da Câmara de Comércio local e decidido solicitar ajuda para estabelecer um negócio e posteriormente mudar-se para o país em questão. A garantia? Uma herança que seu pai, antes de ser assassinado por uma milícia do governo por apoiar os fazendeiros brancos, depositara no valor de 20 milhões e 500 mil dólares em uma empresa de seguros na Holanda - e que, para evitar a detenção de oficiais de imigração, fora despachada em duas caixas e declarada como bens pessoais e material fotográfico. Em cooperação pela transação, que poderia ser feita diretamente com a seguradora (a qual me colocaria como beneficiário legal), eu teria direito a $25 \%$ do valor total. Além disso, deveria me comprometer a assistir o Sr. Mbeki em seus investimentos em meu país. Antes, porém, de comunicar essa "valiosa informação", o autor adverte: "Let me use this opportunity to also inform you that this transaction is 100\% risk free and genuine and should be handled in the most confidential manner. This proposal is Not and must Not be linked to all the numerous scam letter[s] flying around”. Aguarda-se resposta imediata.

Mas a resposta, de minha parte, não veio. Arquivou-se. Assim como se aqruivou o apelo da Sra. Abacha, aparentemente mais uma dessas "numerosas cartas fraudulentas voando por aí". Como pesquisador, no entnato, não me passou despercebida a rede de intertextualidade estabelecida entre esses textos, que se referem uns aos outros, ainda que não por citação direta. Pude entrever as marcas de uma interdiscursividade em pleno movimento - uma forma de inserção nesse arquivo que, como vimos, é formado de memória e esquecimento. Poderíamos dizer que, para cair no golpe, bastaria que os leitores simplesmente "se esquecessem” das mensagens já recebidas, não identificando

\footnotetext{
${ }^{46}$ Ver APÊNDICE B para o texto original completo.
} 
nas novas os traços suspeitos das antigas! Já aqueles que reconhecem imediatamente esses traços têm mais uma oportunidade para se familiarizar com uma forma de discurso que parece ter contornos mais ou menos definidos. E de resistir a seus apelos persuasivos!

Dois anos depois, em 22 de fevereiro de 2005, Eileen (e.schoen) envia para a lista de discussão uma mensagem toda em letras maiúsculas, intitulada Monkey Business?, contendo uma proposta misteriosa (pois incompleta) que ela acabara de receber de um remetente da Espanha:

FROM DORA_CHRISTOPHE@terra.es

HELLO,

PERMIT ME TO INFORM YOU OF MY DESIRE OF GOING INTO BUSINESS RELATIONSHIP WITH YOU. I BELIEVE YOU ARE A REPUTABLE AND RESPONSIBLE TRUSTWORTHY PERSON I CAN DO BUSINESS WITH AND BY MATTER OF TRUST I MUST NOT HESITATE TO CONFIDE IN YOU FOR THIS SIMPLE AND SINCERE BUSINESS.

Eileen pergunta aos demais membros da lista de que se trata ("Wonder what the business is”). A primeira resposta, aparentemente, dispensa maiores detalhes. Fred (fmcnary) sentencia, usando apenas uma única palavra, também em letras maiúsculas: “SCAM!”. Algumas horas depois, no entanto, Melinda Meahan instrui: “Go Google for Nigerian 419 scam and you will find out. It's one of the oldest tricks in the book”. Seja qual for o teor dessa suposta proposta de negócios, ela parece conter os elementos básicos de um golpe que já se tornou um clássico, e que se arquivou na memória sob a rubrica de “golpe nigeriano”. Não que Eileen não soubesse disso. Em sua resposta a Melinda, deixa claro que ela, assim como a maior parte dos membros daquela lista (conforme supõe), já recebeu “inúmeras cartas nigerianas”. Ela esclarece que sua intenção não é obter informações sobre o golpe, mas sim indicar uma nova modalidade que nunca tinha visto antes. Desconfortável com a "necessidade” do esclarecimento, Melinda pede desculpas. Não sem um toque de ironia: “esquecera-se” de que está lidando com uma comunidade que "já sabe tudo sobre essas coisas” e que, portanto, não será ela quem irá educar as pessoas a respeito. Lamenta apenas que tais mensagens tenham de lhe ser encaminhadas e que, no final das contas, ainda seja advertida por “ensinar o padre-nosso ao vigário” (“preaching to the choir”). 
Mas nem todos os vigários estão alertas 100\% das vezes. O “negócio micado” proposto a Eileen motiva Scott a mencionar um e-mail assinado pela chefe do escritório de convenções e turismo do lugar onde mora e que uma amiga sua, ADVOGADA DE VERDADE (como enfatiza), acabara de lhe encaminhar. A mensagem inclui mais de 200 remetentes que, como a advogada, teriam caído no golpe “Bill Gates lhe pagará 250 dólares para cada endereço a que você encaminhar essa mensagem”. Scott se sente mal por sua amiga, pois acredita que ela se fez passar por "uma verdadeira idiota” ( " $a$ complete shmuck”) perante boa parte dos destinatários de sua lista de endereços.

Quer dizer que as cartas nigerianas e afins não são só itens curiosos de uma coleção já clássica. O arquivo que elas constituem vai, sim, se diversificando, ganhando novas versões e nuances. De qualquer maneira, seus “efeitos práticos” permanecem ativos. Uma investigação factual sobre o assunto em fontes como a Divisão de Crimes Financeiros do Serviço Secreto norte-americano nos revelará, por exemplo, que golpes do tipo nigeriano "arrecadam centenas de milhões de dólares anualmente e as perdas continuam em escalada" ${ }^{47}$. Em uma entrevista com Nuhu Ribadu, chefe da Comissão de Crimes Financeiros e Econômicos da Nigéria, publicada em março de 2004 no site da $B B C$ News, ficamos sabendo também dos esforços do governo daquele país no sentido de conter as fraudes e recuperar a confiança perdida. Conforme observa Ribadu: “Isso tem causado tanto dano a nossa credibilidade, a nossa imagem, a nossa honra”.

Barbara Mikkelson entra nesse thread com uma importante contribuição. Primeiramente, ela reforça a idéia de que, de fato, novas versões do golpe nigeriano surgem a cada semana, uma vez que as pessoas que o perpretam mudam de nome e inventam descrições cada vez mais criativas de quão desesperada é a situação dos que precisam dar um "bom destino" aos seus milhões de dólares em dinheiro. Mas mais interessante que isso: Barbara incentiva que se discutam no fórum questões como o porquê de as pessoas continuarem a cair no golpe nigeriano, o que os governos estão tentando fazer a respeito, quão seriamente afetadas foram as vítimas, que fascinação humana a idéia de "ganho fácil” pode exercer e como a importância da riqueza

\footnotetext{
${ }^{47}$ Informação obtida no site http://www.secretservice.gov/financial_crimes.shtml, acessado em 31 de janeiro de 2007. Em um artigo de agosto de 2001, publicado na revista Salon, o editor cita uma declaração feita dois anos antes pelo secretário adjunto para assuntos africanos do Departamento de Estado dos Estados Unidos, Howard Jeter, segunda a qual "Os Americanos perdem 2 bilhões de dólares anualmente para grupos criminosos de colarinho branco sediados na Nigéria” (Cruickshank 2001). Já em um artigo de julho de 2004 da $B B C$ News, o prejuízo citado é de 200 milhões de dólares, segundo estimativa da polícia norte-americana (Damon 2004).
} 
percebida em nossa sociedade mobiliza as pessoas. Como conclui a moderadora, mesmo se “tais tópicos não pareçam ter qualquer relação com folclore, eu acredito que o entendimento de alguns de seus elementos é chave para fazer sentido de por que contamos as histórias que contamos.”

Ora, numa primeira leitura, os golpes parecem mesmo não se encaixar tipicamente no que chamamos de folclore (lendas, rumores, etc.). Barbara inclusive coloca a oposição nos termos de uma deliberação por trás da "remanufatura” dos golpes com o objetivo de enganar um número maior de pessoas versus a suposta mudança natural que o folclore sofre refletindo as preocupações e pontos de vista da sociedade atual. Entretanto, eles parecem ter muito a nos dizer, sim, sobre que histórias privilegiamos contar e por quê. Os golpes estão, acredito, enredados nas inúmeras tramas de narrativas que elaboram nossa experiência cotidiana com relação à riqueza, a ambição desmedida, a solidariedade e o desejo de crença, tanto quanto o estão as “ficções morais” que nos acostumamos a ver nas telenovelas, na literatura popular e nos programas e revistas de fofocas. Mas deveremos nos enveredar um pouco mais nessa linha de reflexão à medida em que seguirmos remexendo o nosso arquivo-corpus.

Se Barbara não se interessa simplesmente por colecionar novas versões do golpe nigeriano, outros membros da comunidade, sim, se interessam. A preferência da moderadora por uma boa - ou mesmo tímida (half-hearted) - discussão sobre o assunto encontra eco em apenas duas mensagens subseqüentes. Estelle Raderman se restringe a requentar a explicação básica e direta - já sugerida na própria interpretação de Barbara - para o porquê de as pessoas continuarem caindo nos golpes nigerianos: no geral, somos ambiciosos; pensamos que podemos ter ganho fácil ("gonna get sum'pin for nuttin”). Sherpa, “citando” o raciocínio ainda uma segunda vez, acrescenta: “You can't get something for nothing. You can't have freedom for free”. Para os incautos, a quem os enunciados mais que recorrentes desse discurso de inspiração liberal "não terão lhes ocorrido”, aí está a lição generalista que a parca discussão poderá ensinar.

De fato, em sua maior parte, os membros da comunidade parecem mais interessados em simplesmente continuar compartilhando suas versões, ou, por assim dizer, continuar revirando o arquivo. Assim é que Ktxzkat tenta evocar a história de um tal escritor (cujo nome não consegue encontrar no Google) que caiu em um golpe 419, mesmo tendo escrito um livro sobre pessoas idiotas. Jack Ruttan, ciente da restrição sugerida pela moderadora, não resiste em compartilhar a menção a uma carta nigeriana 
que recebera, na qual um suposto parente seu, um tal Ruttan, estaria na Nigéria aguardando transferir os milhões para sua conta.

Pat Dugan também envia ao grupo uma cópia de seu mais recente 419 (My latest 419), em que um cidadão da Coréia do Norte, desertor da política autoritária de seu país, encontra-se na Coréia do Sul buscando oportunidades para aplicar o dinheiro que conseguira transferir para fora de seu país de origem antes do exílio. Conclui a proposta: "I want to invest this funds in your Country with your help and advice because we are being treated as foreigners here”. Eis mais uma história, portanto, de dimensões globalizadas, em que muito dinheiro está pronto para ser movido para além das fronteiras políticas e ideológicas. Para a coleção, mais um golpe nigeriano, sem no entanto passar necessariamente pela Nigéria!

Finalmente, Annie (Anyaschi) remete os leitores a um $\operatorname{link}^{48}$ contendo todo o incrível histórico de mensagens trocadas entre um suposto príncipe Joe Eboh da Nigéria e sua potencial vítima, o padre Hector Barnett, responsável pelo departamento de desenvolvimento financeiro da Holy Church of The Order of The Red Breast - algo como "Sagrada Igreja da Ordem do Peito Vermelho” - , igreja cristã missionária, baseada na Inglaterra e fundada por Betsy Carrington em 1774. Os membros dessa igreja, em sinal de sua fé, pintam em vermelho um símbolo semelhante ao número 9 ao redor da barriga (no caso das mulheres), ou do mamilo direito (no caso dos homens, repetindo assim o ritual fundador executado pela própria Senhorita Carrington diante de uma tribo de guerreiros Masai no Quênia). A proposta, chancelada por uma série de referências a leis, instituições e cargos institucionais nigerianos, envolveria a transferência de 25 milhões de dólares em dinheiro, dos quais 20\% iriam parar na conta bancária da vítima no exterior. Até esse ponto, nada de muito original em relação ao modelo (ou texto-padrão virtual) de golpe nigeriano. Ocorre que, para se integrar ao esquema, o padre Barnett necessita que Eboh se converta à sua igreja imaginária, processo que implicará, no final de várias correspondências e "trâmites operacionais" como o envio de fotos (falsas, de ambas as partes) e o preenchimento e envio de um “termo de indução” -, o pagamento de 89 dólares pelo golpeador à sua vítima! Como resume Annie “This guy scammed the scammer... and got \$\$!!!”.

\footnotetext{
${ }^{48}$ www.419eater.com, site dedicado exclusivamente ao esclarecimento e o combate sobre os diversos golpes financeiros em circulação na Internet, concentrando-se em especial nos do tipo 419. É rico em documentação, fotos e dicas, além de promover um fórum aberto a qualquer leitor interessado no assunto.
} 
Um intervalo no fluxo de mensagens sobre golpes nigerianos se estabelece na lista. Mas não muito duradouro. Quatro meses depois, em junho, Michael Funicelli encaminha ao grupo o que seria uma versão do mundo árabe para o golpe nigeriano. Evocando Alá, o Senhor Usman Ahmed Y. - que assina a carta, incluindo seu endereço de e-mail cuja extensão it sinaliza uma procedência italiana - espera ter encontrado a pessoa certa a quem deverá confiar a transferência de um fundo por ora sob a custódia de uma agência de seguros em Dubai, nos Emirados Árabes. Iraquiano de origem, o Sr. Ahmed coloca claramente as razões para sua proposta: as circunstâncias políticas altamente instáveis em seu país representam um entrave que impossibilita o trânsito livre para o exterior e as oportunidades de negócios internacionais. Em suas palavras: "The fall of Saddam Hussein has brought destruction/Hell to our great country and everything is practically difficult now and opportunities are closing up, the new government is trying to frustrate our businesses". Tudo o mais permanece bastante dentro dos parâmetros que, a uma altura dessas, já aprendemos a reconhecer: o interessado deverá se deslocar até o país onde se encontra o dinheiro, abrir uma conta bancária em seu país com as credenciais a lhe serem concedidas e, mediante o trâmite de documentos e códigos especificados, terá o direito a (dessa vez) 30\% do montante da operação.

Nessa conexão iraquiana, permito-me avançar no tempo até o presente recentíssimo, quando ainda me subscrevo ao grupo de discussão do Snopes, para reproduzir uma mensagem, datada de 23 de janeiro de 2007, onde novamente o Nigerian scam goes to Iraq. Encaminhada à lista por Anyaschi, de sua correspondência pessoal, diz a carta:

\section{Hello Pal,}

I need of your assistance. My name is Sgt. Jarvis Reeves Jr. I am a military attache with the Engineering unit here in Ba'qubah Iraq for the United States, we have about \$14 Million dollars that we want to move out of the country. My partners and I need a good partner someone we can trust to actualize this venture.The money is from oil proceeds and legal.But we are moving it through diplomatic means to your house directly or a safe and secured location of your choice using diplomatic courier services.

But can we trust you? Once the funds get to you, you take your $30 \%$ out and keep our own $70 \%$. Your own part of this deal is to find a safe place where the funds can be sent to. Our own part is sending it to you. 
If you are interested I will furnish you with more details.

Awaiting your urgent response.

Your Buddy.

Sgt Jarvis Reeves

God Bless America!!!!!!

A julgar pelo teor das mensagens, algo une americanos e iraquianos, pelo menos nesse universo de identidades virtualmente constituídas. Todos querem (ou podem) participar do mercado livre de capitais migratórios. O que lhes impede é a contingência absolutamente restritiva dos regimes políticos a que são submetidos - no caso dos americanos, o fato de estarem cumprindo sua missão no Iraque; no dos iraquianos, o jugo do legado de Saddam Hussein. Caberia, então, perguntar: o que exatamente estaria "restringindo" os africanos? Como é que eles são implicados nessa promessa de "livre participação” nas benesses capitais do mundo globalizado? Quer dizer, se há algo de específico na situação deles, o que é?

Arriscaria dizer, sob o risco de uma certa generalização, que, para além do estado de exceção, a ditadura política, a corrupção, o desemprego e outras misérias materiais, o que os golpes nigerianos mobilizam vivamente, numa dimensão simbólica, é o imaginário exótico sobre o africano - esse estranho do continente sombrio, com suas transações secretas, sua aura de risco, mistério e aventura selvagem. Um olhar mais atento para os textos nos mostra como eles mobilizam esse “outro” que é identificado por nomes misteriosos e pomposos e cujo discurso é materializado em um registro lingüístico um tanto canhestro (do inglês, nesse caso), porém evocativo, por vezes sintaticamente estranho mas ao mesmo tempo formal e lexicalmente sofisticado - um tanto mais, por contraste, do que aquela fala direta e "militarista” do sargento Reeves. Enfim: a promessa de milhões de dólares destinados a testar a ganância de quem quer que se interesse e eventualmente "caia no golpe" - um cobrador de impostos no Canadá?, um renomado psiquiatra na Califórnia?, um veterano da Guerra do Vietnã em Massachussetts ${ }^{49}$ - vem embalada no papel vistoso de uma trama narrativa imemorial.

Trata-se de reconhecer nos acontecimentos dos golpes nigerianos a estrutura desenhada por uma longa tradição narrativa. E nessa tradição, que é ficcional, podemos identificar algumas “verdades” recorrentes, dentre as quais, nesse caso específico: a de

\footnotetext{
${ }^{49}$ Referências a casos de vítimas "reais" do golpe nigeriano relatados na mídia e mencionados em mensagens do corpus entre agosto de 2005 e maio de 2006.
} 
que a malícia e a desonestidade são associadas a determinados povos (mais que a outros), a de que excluídos históricos são capazes de se vingar (adotando estratégias "herdadas” de quem os exclui), a de que lições de moral são aprendidas ao custo de uma perda material e a de que ambiciosos impulsivos se dão mal no final.

Trata-se de considerar também, sob um outro ponto de vista, a possibilidade sempre presente de se projetar identidades, habitar as posições-de-sujeito que a cultura disponibilizou de modo tal que, em princípio, qualquer usuário da Internet pode se apropriar de um nome fictício, forjar documentos oficiais, criar uma rede de confiança (ou igreja imaginária), e se passar por herdeiro de uma fortuna milionária na Nigéria, ou agente do governo nigeriano, ou padre missionário inglês, ou ainda investidor nortecoreano - seja em que parte do planeta estiverem! A perspectiva de ganho fácil, que parece ser a única justificativa para a mobilização em torno de sempre novos golpes, apresenta-se, assim, como apenas uma faceta (a mais material, talvez) do trabalho de identificação simbólica - trabalho ininterrupto, sempre renovável e nunca definitivamente estabelecido - no qual esses tantos sujeitos desejantes podem investir.

Tudo indica que eu poderia continuar colecionando versões do golpe nigeriano ao longo de anos. Um retorno ao arquivo que guardo desde o ano 2003 me revela outras tantas mensagens contendo variações da mesma trama. Alguns dos textos, colhidos de fontes jornalísticas, se constroem como verdadeiras narrativas ficcionais seguindo um enredo de ascenção e queda que está perfeitamente de acordo com certos romances e filmes que já lemos ou vimos antes. Um enredo que poderia ser esquematizado da seguinte forma: vida tranqüila $\rightarrow$ despertar do desejo de tornar-se (mais) rico $\rightarrow$ complicações e embaraços crescentes $\rightarrow$ ruína gradativa e secreta $\rightarrow$ redenção mínima. Já outros textos exploram a astúcia, a ironia e outros sinais evidentes que denunciam a farsa - num movimento racionalizante de “desbancar a lenda” e afirmar uma consciência prática. Seja qual for a abordagem, permanece o traço, persiste a marca: a positividade de um discurso que não se esgota. É como se existisse uma espécie de “excesso de arquivo” que confere à expressão golpe sem fronteiras um efeito de sentido para além da dimensão espacial dos países e dos capitais internacionais livremente transitáveis. 


\section{Pains and Needles}

O segundo ciclo de lendas a que se dedica este capítulo envolve novamente o tema do risco de contaminação. Agora não por comida ou bebida, mas por agulhas. Refiro-me ao fantasma da AIDS, doença que em pleno início de século XXI se encontra ainda rodeada de mitos e, por que não dizer, franca ignorância. Não foram poucas, certamente, as dúvidas que se materializaram nos discursos sobre a doença quando esta ainda se encaminhava para a condição de epidemia mundial. Afinal, de que formas se transmitia a AIDS? Quem a transmitia? A quem? Como evitá-la? Questões como essa exigiam respostas inequívocas as quais por muito tempo - e ainda hoje - competiram com toda sorte de desinformação e preconceitos. Para citar apenas um exemplo disso (examinarei outros ao longo desta seção), reporto-me aos resultados de um estudo promovido pela Rand Corp. e a Oregon State University, publicado em janeiro de 2005, segundo os quais aproximadamente $50 \%$ dos 500 negros norte-americanos entrevistados acreditavam que o vírus que causa a AIDS tivesse sido fabricado em laboratório por cientistas brancos, numa espécie de grande conspiração de genocídio contra a raça negra. Segundo artigo publicado na época pelo jornal The Washington Post, mais de 1/4 disseram acreditar que a AIDS foi produzida em um laboratório do governo, e 12\% acreditavam que a doença foi criada e propagada pela CIA. Além disso, pouco mais de metade dos entrevistados (53,4\%) declararam acreditar que existe cura para a doença, mas que tal informação é mantida pelo governo como um segredo contra a população pobre $^{50}$. Citado no artigo, Phil Wilson, diretor executivo do Instituto Black AIDS em Los Angeles, conclui: “A noção toda de teorias da conspiração e desinformação (...) afasta a responsabilidade pessoal. Se existe esse bicho-papão, as pessoas dizem, 'Por que eu deveria usar camisinha? Por que eu deveria usar agulhas limpas?' E se eu sou uma organização, 'Por que eu deveria me importar em educar a minha comunidade?'” $(\text { Fears 2005) })^{51}$.

De fato, como uma espécie de "bicho-papão”, a AIDS se presta(va) a determinadas metáforas que foram se transformando ao longo do tempo. Ora incidindo

\footnotetext{
${ }^{50}$ Fine \& Turner (2001: 157-166) e Goldstein (2004: 91-95) discutem como concepções desse tipo foram sendo alimentadas - inclusive entre celebridades e líderes negros influentes nos Estados Unidos - desde o aparecimento da doença no início da década de 1980.

${ }^{51}$ Artigo enviado ao grupo de discussão por Brian Chapman no mesmo dia de sua publicação, em 25 de janeiro de 2005.
} 
sobre os gays, ora sobre os africanos, negros, doadores de sangue, viciados em drogas, cientistas americanos ou amantes promíscuos, tais metáforas associa(va)m doença e moralidade de forma inequívoca e bastante explícita - motivo que de certa forma contribuiu para a manutenção da mistificação, da nuvem de incompreensão e medo em torno de uma questão social de proporções planetárias.

Não seria de se estranhar, portanto, que narrativas apócrifas se infiltrassem nesse terreno, gerando teorias conspiratórias, rumores e lendas urbanas - algumas já clássicas, mas cujos motes seguem se metamorfoseando a cada ano. Um desses clássicos é certamente o que envolve o risco de contaminação por agulhas plantadas em assentos de teatros e cinemas, em receptáculos de moedas em telefones públicos ou em bombas de gasolina. Ainda em agosto de 2002, recebia em minha caixa de correio eletrônico a primeira mensagem desse tipo - a segunda na ordem cronológica de todo o meu arquivo - me alertando sobre o perigo. Tratava-se, possivelmente, da primeira fonte pela qual me foi dado conhecer a existência de um verdadeiro ciclo de narrativas onde a agulha é elemento protagonista. A mensagem, contendo o nome e o e-mail de uma série de remetentes anteriores a quem havia sido encaminhada, e enviada por um executivo de uma empresa multinacional alemã situada no Brasil a uma amiga minha, apresentava no campo “assunto" simplesmente a palavra UNICAMP. Reproduzo o corpo da mensagem em sua formatação original:

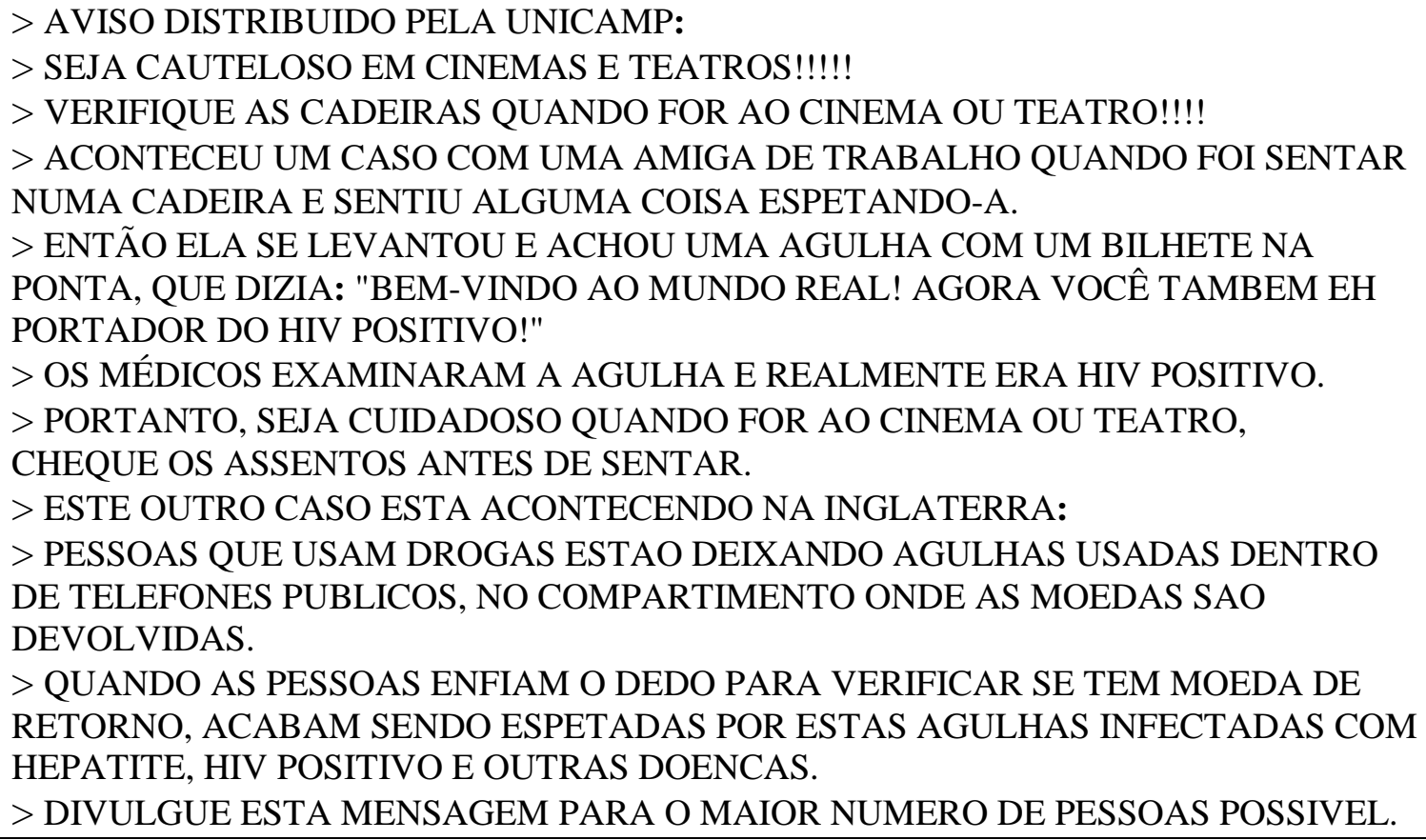


Alguns sinais denunciam logo tratar-se de uma lenda urbana, ou pelo menos de um exemplar característico do gênero: a menção a uma instituição de prestígio (uma universidade pública respeitada no país) que contribui para legitimar a "veracidade” do relato; referências vagas à vítima - “uma amiga de trabalho” - e a um caso que "está acontecendo na Inglaterra"; a imprecisão de termos usados - em "portador do HIV positivo" e “agulhas infectadas com hepatite, HIV positivo e outras doenças”, onde HIV positivo equivale ao nome de uma doença - e o apelo à divulgação do alerta ao "maior número de pessoas possível”. Questões factuais do tipo: como pode uma agulha contaminada estar estrategicamente posicionada em um assento ou (mais curiosamente ainda) em um receptáculo de moedas, ou quem a teria plantado lá e com que intenção, escapam, obviamente, a uma "primeira leitura”, cuja orientação principal é no sentido do pânico e do alerta. Antes mesmo de se poder avaliar a "factibilidade” do narrado, é preciso que o relato siga adiante, que seja encaminhado ao maior número possível de remetentes - colegas de trabalho, amigos, familiares.

Uma pesquisa em coleções publicadas e sites sobre lendas urbanas aponta para o que já poderíamos suspeitar. O “alerta da Unicamp” não é a primeira narrativa desse tipo sobre a AIDS de que se tem notícia. De acordo com (nossa já bem conhecida) Barbara Mikkelson, o alerta, em suas inúmeras versões locais difundidas desde a década de 1990, é uma variante da popular AIDS Mary - esta sim, provavelmente a primeira lenda sobre o tema. AIDS Mary tornou-se conhecida no final de 1986, quando o medo de contrair AIDS entre heterossexuais - já não apenas entre homossexuais, como de início ocorreu - atingia um momento crítico na história social da doença. Em sua versão mais comum, a lenda relatava o caso de um rapaz que, comemorando seu aniversário de 21 anos, é embebedado pelos amigos e ganha de presente uma noite em um quarto de hotel com uma prostituta. Na manhã seguinte, ao se dirigir ao banheiro, o aniversariante dá de cara com a seguinte mensagem, escrita com batom, no espelho: "WELCOME TO THE WORLD OF AIDS”. Numa versão masculina, a AIDS Harry, a vítima da contaminação é uma mulher, geralmente uma namorada fiel. Uma das justificativas mais plausíveis para tal ato de crueldade seria o desejo de vingança (indireta) contra alguém do sexo oposto, que, ciente de sua condição de HIV positivo, teria sido o causador (irresponsável) da contaminação primeira.

As narrativas do tipo “alerta da Unicamp” e AIDS Mary/Harry, entretanto, remontam a períodos pré-AIDS, ainda bastante afastados em relação ao momento em 
que a doença começava a capturar o imaginário de indistintos “grupos de risco” (essa outra nomenclatura provando ser uma “ficção provisória”, afinal ${ }^{52}$ ). Mikkelson nos leva de volta a Nova Orleans, décadas de 1920 e 1930. Na época, garotas adolescentes eram alertadas para o perigo de serem atacadas pelos chamados Needle Men ("Homens da Agulha”). Elas recebiam a instrução de se sentarem sempre nas extremidades das fileiras nos cinemas, nunca no centro, evitando assim atrair a atenção de "escravizadores brancos”. Estes elementos suspeitos, agindo em duplas, sentavam-se cada um de um lado da garota, injetavam-lhe morfina e carregavam-na para fora do local e "para dentro de uma vida de vergonha” (into a life of shame) ${ }^{53}$. Numa outra versão, os “needle men” seriam estudantes de medicina, agindo em cinemas, mas também em ônibus e nas ruas, em busca de cadáveres para dissecação.

Poderíamos seguir numa investigação histórica mais extensa buscando outras tramas, outros fios interdiscursivos em que histórias diversas como essas fariam algum tipo de intersecção. Provavelmente iríamos encontrar tantas outras histórias de ameaças de contaminação por agulha, outras em que garotas inocentes arriscariam se tornar “escravas brancas”, ou outras em que lugares públicos aparentemente inofensivos (como as dos hipermercados e shopping centers analisadas no capítulo anterior) esconderiam ameaças à segurança e bem-estar de seus freqüentadores... Por ora, no entanto, ponho-me a rastrear as mensagens do corpus de 2005 que giram em torno da AIDS a fim de examinar os fios narrativos que se podem aí identificar.

Em 27 de abril daquele ano, ficamos sabendo, por meio de um artigo de jornal enviado por Brian Chapman, de um rumor que então circulava nas Ilhas Salomão. Segundo o artigo, pessoas supostamente infectadas com o vírus HIV estariam circulando em ônibus e eventos públicos injetando pessoas inocentes com agulhas infectadas. As autoridades do pequeno país, que registrara apenas cinco casos da doença em sua história, estariam investigando a possível (e improvável) veracidade do rumor. Quatro dias depois, nos chega outro relato envolvendo um ônibus e uma agulha. O garoto de dois anos de idade Jesus Hernandez, viajando com sua avó Marilu em um

\footnotetext{
${ }^{52}$ No breve histórico da AIDS apresentado em Soares (2001), vemos como foi a partir da identificação dos chamados "grupos de risco", pelo menos numa fase inicial da história da doença, que foi se estabelecendo "a maior parte dos preconceitos que se tornaram elementos fundamentais para a transformação da Aids em epidemia" (op. cit.: 83). A partir dos anos 1990, o uso do termo "grupo de risco" passou a ser questionado, sendo substituído gradativamente - ainda que permaneça com alguma força no imaginário popular - por "comportamento de risco" ou "vulnerabilidade".

${ }^{53}$ Citação de http://www.snopes.com/horrors/madmen/pinprick.asp, acessado em 6/2/2007.
} 
ônibus da companhia Greyhound, se espeta em uma agulha posicionada sob seu assento pouco depois de deixar Portland, no estado americano de Oregon. Alertado sobre o ocorrido, o motorista do ônibus providencia atendimento emergencial em um hospital de Medford, cidade próxima, onde a agulha é examinada e amostras de sangue do menino são testadas. Uma porta-voz da empresa afirma nunca ter ouvido falar de caso semelhante, e que todos os ônibus são limpos antes de partir. No dia seguinte, um terceiro artigo reporta a recente onde de sensacionalismo na imprensa do Quênia motivada por um suposto caso de contaminação em massa por uma estudante de direito da Moi University, em Eldoret. A estudante, que permanecia anônima, havia postado no mural da faculdade uma lista com os nomes das 118 pessoas (incluindo diversos professores) que ela, por vingança, teria infectado com HIV. Mais uma versão, portanto, de AIDS Mary. Por fim, seis meses depois, em 30 de novembro, um relato (sem agulhas, mas igualmente surpreendente) nos informa que em Sofala, província no centro de Moçambique, uma grande quantidade de pessoas soropositivas estaria se recusando a comer carne moída vinda de doações assistenciais dos Estados Unidos por acreditar tratar-se de carne de origem humana. Estaríamos aqui diante de mais uma manifestação da velha teoria da conspiração de brancos contra negros? Ou de uma nova articulação do velho motivo do canibalismo? De qualquer maneira, verdadeiros ou não, os relatos trazem à tona motivos que nunca deixaram de estar lá, no arquivo, como que simplesmente aguardando sua mais recente atualização.

Assim, seguindo nosso percurso, vemos surgirem em 2006 umas outras tantas narrativas que se somam à nossa já intricada rede de tramas paralelas, tecidas no interdiscurso. A primeira delas, reportada em um site de notícias indiano (www.sify.com) em 19 de fevereiro, aborda mais uma vez o pânico das agulhas infectadas no cinema. De acordo com o artigo, e-mails de alerta estariam circulando recontando a mesma trama como tendo ocorrido em cinemas lotados e clubes noturnos em Paris, Londres, Mumbai e Dehli. Com informações médicas e de ONGs dedicadas ao combate à AIDS, as quais afastam a possibilidade dos relatos terem realmente acontecido, o artigo conclui tratar-se, afinal, de mais uma variante de AIDS Mary, a popular lenda dos anos 1980. Três meses depois, em 10 de maio, o site NewsIndPress.com ainda aborda essa onda de e-mails assustadores, comparando-a a algo semelhante ocorrido na Índia quase 10 anos antes. Mas antes disso, outro artigo, publicado em 9 de março em um jornal de Athens, Georgia (o Athens Banner-Herald), é 
enviado trazendo um follow-up sobre o caso de uma mulher de 34 anos que teria de fato sido espetada por uma agulha, cinco meses antes, em um cinema de um shopping center local. Nenhuma conseqüência grave teria advindo do incidente, embora não tivesse sido possível testar o material - aparentemente sangue seco - encontrado em insuficiente quantidade no interior da seringa. Nesse caso, a memória viva de um conteúdo lendário é explicitamente evocada, numa circunstância em que os detalhes de um "fato real”, segundo o artigo, “espelham” os de uma lenda urbana.

Até aqui, a sucessão de relatos, em artigos enviados quase sempre pelo mesmo membro do grupo, parece criar um efeito quase que exclusivamente acumulativo. Aparentemente, estamos, como participantes da lista, recebendo os últimos updates de uma "matriz" textual-discursiva já sedimentada em um arquivo de "conhecimento geral”. Ocorre uma espécie de materialização do princípio do suplemento, tal como o formula Derrida. Como vimos anteriormente (Capítulo 3, seção 1.1), para o autor, a repetição só é possível numa relação de suplementaridade entre o que repete e o que é repetido. No caso aqui, as “atualizações” propostas para a leitura dos membros do grupo operam discursivamente de modo a acrescentar, "na falta de uma unidade plena, uma outra unidade que vem supri-la, sendo ao mesmo tempo a mesma o bastante e outra o bastante para substituir acrescentando” (Derrida 1972/2005: 121). Em outras palavras, os textos suplementam uma suposta completude - digamos, o imaginário/arquivo ao redor da AIDS - ao mesmo tempo em que suprem uma falta: “O que há de novo a dizer sobre a AIDS? Qual é a última?”. É o princípio de toda marca, de todo traço (de toda escritura, no sentido que a ela é dado por Derrida): permanecer sem ser nunca "só ele mesmo" e nunca "sempre uma coisa nova e distinta”.

Retomando ainda, nessa junção, o que Foucault chama de princípio do comentário (Capítulo 1, seção 2.2.1), poderíamos afirmar que o relançar de textos em sucessão, inscritos numa ordem discursiva tal como a da lista de discussão, representa a tentativa de preencher um dizer constitutivamente incompleto, visando (projetivamente) à possibilidade de que uma nova série de regularidades venha a ser descrita - isto é, que os dizeres sobre a AIDS sejam reestruturados em função da ação sempre movente dos acontecimentos enunciativos que se dão “em seu nome”.

Comentar, ainda que por meio de uma sucessão de textos deixados "sem comentário” - já que não houve propriamente um “debate” sobre eles -, significa aqui um exercício, uma prática de deslocamento dos sentidos que segue na direção ora de 
reforçar os estereótipos, a desinformação e os preconceitos em torno de uma questão de saúde que pode afetar a qualquer um sem distinção, ora de corrigir estes mesmos, por meio de desmentidos e informações autenticadas por saberes oficiais institucionalizados. E, é claro, essas duas direções não serão, em si mesmas, as únicas direções possíveis a que o discurso sobre a AIDS irá nos conduzir. Tampouco elas serão mutuamente excludentes em um mesmo texto-acontecimento. A leitura atenta do corpus nos permite compreender, de qualquer forma, que, pelo princípio da suplementaridade, o discurso faz sempre e a cada vez relançar os saberes, "revirar” as páginas do arquivo, propondo comentários inesgotáveis sobre a "mesma e velha lenda".

Assim, pois, um episódio de junho de 2006 acende uma nova onda de comentários na lista - estes mais "explícitos", materializados em um longo e intenso thread de discussão -, vindo a quebrar um pouco a rotina silenciosa das atualizações. Trata-se do caso envolvendo uma mulher branca inglesa que resolveu se vingar de um amante negro que lhe havia contaminado com HIV, transmitindo o vírus deliberadamente para outros homens negros. $\mathrm{O}$ relato nos chega como um link a um artigo do jornal sensacionalista britânico The Sun, publicado no dia 20 daquele mês. Reproduzo abaixo a primeira parte do artigo, que contém os detalhes fundamentais da história:

\section{News \\ Ex tells of HIV nightmare \\ By MIKE SULLIVAN \\ Crime Editor}

A BITTER blonde infected with the Aids virus went on a vengeful mission to spread the disease.

Sarah Jane Porter, 43, was made HIV positive by a black lover — and set out to pass it to other Afro-Caribbean men.

She is thought to have had unprotected sex with DOZENS.

The single mum, of Kennington, South London, was yesterday jailed for infecting one ex — and branded "pure evil".

A former lover of Porter told last night how she set out on a callous "payback mission".

The 37-year-old man — known as Mr B — called her "sick in the head".

And he told how she continued to sleep around even while awaiting trial for deliberately infecting another ex.

Mr B said: "She caught HIV off a black guy and now she’s on a payback mission. All the guys she has slept with are black. 

as well?'.

"Her thinking seems to be, 'Why should I be the only one to suffer? Why shouldn't they suffer

"Sarah is very, very attractive — the sort of woman any guy would love to be with.

"But make no mistake, she is a very dangerous woman."

The lover she infected, known as Mr C, branded her "pure evil”. Porter, a Vidal Sassoon salon receptionist, is thought to have had unprotected sex with DOZENS of young Afro-Caribbean men she met in nightclubs.

One is a well-known figure in the music world.

Yet she feigned shock and tears when Mr C discovered he was HIV positive — and let him believe HE had infected HER.

It was not until months later that the victim, an events manager, discovered through a mutual friend that Porter was carrying the deadly Aids virus BEFORE she met him.

She was jailed for 32 months at Inner London Crown Court yesterday for "recklessly" causing Mr C grievous bodily harm.

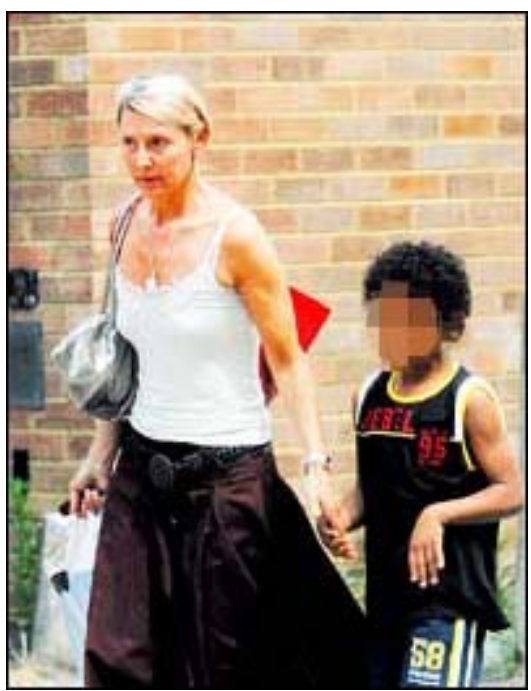

Wicked mum ... Porter with her son, his identity disguised

A história da AIDS Avenger ("vingadora da AIDS"), como Porter ficou conhecida na mídia, começará a ser comentada pelo grupo, na verdade, somente dois meses depois, quando um novo artigo é enviado - mais uma vez, pelo assíduo Brian Chapman - trazendo as primeiras declarações da mulher desde sua prisão, em entrevista exclusiva. O artigo, publicado no também britânico News of the World, conta como Porter se sente culpada e arrependida pelo que fez, mas nega ter agido por vingança. Afirma ter dormido com apenas três homens desde que soube que era soropositiva - em 2000, seis meses após o nascimento de seu filho com o homem que lhe transmitira a 
doença - e que lhes escondera o fato por não conseguir, ela própria, aceitá-lo. Assim é que, procurando seguir a vida como se nada tivesse acontecido, ela teria transmitido o vírus para seus próximos amantes (Mr. B e Mr. C). Na entrevista, Porter afirma ainda ter quase ingerido um vidro de alvejante líquido ao ser informada de sua condição e, posteriormente, ter tentado duas vezes o suicídio. A prisão, porém, teria sido, segundo ela, um acerto de contas consigo mesmo, uma oportunidade para que o ciclo de negação (denial) se interrompesse.

Os esclarecimentos de Porter, ao que parece, concorrem para evitar que sua história se transforme meramente na mais nova versão de AIDS Mary (AIDS Sarah Jane, AIDS Avenger), embora tenha sido com essa matriz discursiva que alguns dos primeiros artigos de jornais britânicos sobre o caso se comunicaram diretamente. Há sinais disso na reportagem do The Sun. A começar, a primeira frase do artigo, que, embora esteja bem de acordo com a linguagem característica de um tablóide sensacionalista, poderia muito bem ser a sinopse de uma lenda urbana em uma coletânea qualquer do gênero: “A BITTER blonde infected with the Aids virus went on a vengeful mission to spread the disease” ("Uma loira RESSENTIDA infectada com o vírus da Aids saiu em uma missão de vingança para espalhar a doença”). Em seguida, afirma o artigo: foram DEZENAS (“DOZENS”, em letras destacadas) as supostas vítimas da mulher, uma mãe solteira a quem seu ex-amante classifica como "doente da cabeça" (sick in the head), "maldade pura” (pure evil).

A trama narrativa segundo a qual a mulher enganada se vinga com fúria absoluta paira por aqui como um espectro pronto para se materializar. Sejam os detalhes verdadeiros ou não, é a estrutura básica desse enredo que contribui para compor o artigo do The Sun, o qual, ainda que "sensacionalista” por princípios editoriais - isto é, princípios que orientam o pacto tácito entre esse tipo de texto e seus leitores -, pode sempre ser lido como um "texto jornalístico informativo" (vide a rubrica News, logo acima da manchete).

Quanto ao ciclo de comentários inspirados pela história de Sarah Jane, este teve início dois dias depois, a partir da seguinte mensagem - uma espécie de stream of consciousness (“fluxo de consciência”) um tanto inusual para os padrões do fórum -, assinada pela newbie Bonnie Howell ${ }^{54}$ :

\footnotetext{
${ }^{54}$ Mensagem reproduzida com a pontuação e os vários erros de ortografia do original.
} 
This is sad.. and this is something the doctors can stop they have a cure besides the fact it should be branded on there forhead or chin where ever visable so they cant go on a revenge trip,,,I feel for all the people that have gotton this awful killing desease by someone who just would not tell that they have it,,,you can have it and still live a normal life with someone who really knows you and cares about you,,,dont hurt others just because someone hurt you,,, this diesease was meant to controll the human race just like cancer they have a cure for it also....but however it makes the doctors and hospitals lots of money....if you are diognosed with this please get several opions if I had freaked out 11 years ago I would probley be dead but ignored what my doctor said and whet somewhere else a year or so later guess what no cancer and my daughter is very heathy she is going to be 12 in october...I hate to say it but I am living proff that they may say you have it just to make money start radiation and then your life is over for no reason....please take my advise dont freak get 1 or 2 or 3 opions before you listen to one doctor no matter how much you trust them..

Não demoram a chegar as primeiras reações. Emocionante o quanto possa ser o relato de alguém que se curou de um câncer e que acredita existir cura para uma doença “criada para controlar a raça humana”, para Azzizza, a primeira respondente, aí está alguém que parece não entender o objetivo primordial da lista de discussão: “desbancar [as lendas urbanas], não perpetuá-las ainda mais”. Já Joe Yuska pondera: “até onde eu saiba, estamos aqui mais para entender as lendas urbanas... e por que elas são transmitidas". Ele não acredita que Howell esteja "blefando" (trolling ${ }^{55}$ ) com uma história tão séria e pessoal, e por isso sugere que se pergunte a ela em que fatos ela baseia suas opiniões sobre medicina, curas e afins. Se ela está confusa, talvez seja ali o local para análise e estudo, entendimento e não retórica (leia-se ironia). Azzizza rebate afirmando não se importar que pessoas postem mensagens dizendo não saber se algo é verdadeiro ou não e gerando discussão; mas, quando alguém vem destilar uma verdadeira bobagem (utter nonsense) como crença inquestionável (gospel truth), essa pessoa deve ser advertida.

Mais de 30 mensagens se seguem. Não caberia aqui discutir cada uma delas. No entanto, poderíamos agrupar os argumentos propostos mais ou menos da seguinte forma:

a. Howell não estaria totalmente equivocada quanto à cura do câncer. Em algumas formas da doença, a remissão pode, sim, ser considerada como cura. No início de sua mensagem, no entanto, ela teria claramente expressado sua crença na existência

\footnotetext{
${ }^{55}$ Termo usado na computação para se referir à atividade de postar mensagens deliberadamente falsas sobre assuntos delicados com o objetivo de chamar atenção e provocar respostas.
} 
de cura para a AIDS - o que o conhecimento científico, como se sabe, ainda não pôde comprovar. Sua "teoria infundada" pertenceria melhor, portanto, a uma lista de discussão sobre conspirações.

b. Reduzir o discurso de Howell à mera ignorância e relegá-lo ao ostracismo interfere na busca de um entendimento sobre os mecanismos pelas quais "os deuses do mal" (evil gods, nos termos de Joe Yuska) podem assumir formas cotidianas, que as pessoas em geral conseguem entender e com as quais podem se identificar. Um ambiente mais amistoso e aberto (e menos condenatório), que é supostamente o da lista, deveria continuar favorecendo esse tipo de reflexão.

c. A mensagem de Howell traz conselhos úteis quanto ao enfrentamento de uma doença, mas não contribui nada para a discussão em torno da AIDS Avenger referência à história da mulher inglesa, já classificada aqui como mito pela participante Vicki PS ("the myth around the 'Aids Avenger'”).

d. A Howell deveria ser dada a chance de se explicar melhor, tornar claras as fontes de suas concepções errôneas. Estas poderiam muito bem ter sido alimentadas por médicos que supostamente detêm o conhecimento dos fatos e deveriam evitar que a desinformação e o preconceito se alastrassem.

São todos argumentos "verdadeiros" - apontando para formações discursivas distintas porém interligadas -, todos perfeitamente "defensáveis” dentro de um fórum que promove a discussão "esclarecida” do tema Lendas Urbanas. Mas Bonnie Howell, o estopim de toda a discussão, não voltou a se manifestar. Sua resposta, esperada conclamada até -, não veio em nenhum momento, pelo menos não na forma de um segundo post. De qualquer maneira, este talvez fosse dispensável. Por si só, o desejo de esclarecimento (que é o desejo de poder saber) talvez representasse apenas uma forma de projeção, uma tática mais ou menos consciente visando a amarrar os vários fios tecidos pela prática interdiscursiva que teve lugar a partir daquela manifestação "primeira". Talvez o "fluxo de consciência" de Howell tenha vindo simplesmente “espanar o pó” do (já amarelado) arquivo lendário sobre a AIDS. Sua inserção, única e precisa, funcionaria como uma marca repetível, que se abre mais uma vez à possibilidade, sempre presente, do suplemento - da iterabilidade, recuperando Derrida dentro de uma prática contextualizada. Aos outros participantes caberia seguir puxando 
os fios enredados da trama interdiscursiva, ou simplesmente interrompê-la (ainda que provisoriamente) quando assim o desejassem.

Assim é que as concepções de que (1) a AIDS é uma doença criada para controlar populações (minorias vitimizadas?) e sua cura, já conhecida, vem sido mantida em sigilo e (2) pessoas (mulheres vingativas?) saem por aí deliberadamente contaminando dezenas de parceiros sexuais tiveram ambas mais uma chance de se manifestar na ordem do discurso - desta vez invadindo os limites (contestados, negociados, nunca definitivamente estabelecidos) de uma "sociedade de discurso" que está pronta para desbancá-las, ao mesmo tempo em que as recicla, em seus ritos, com sempre mais e novos comentários.

\section{Trick or Treat? - Mais e novas "surpresas"}

O terceiro e último ciclo de lendas discutidas neste capítulo representa tipicamente o que se poderia chamar de "lenda com data marcada". Todos os anos, na noite de 31 de outubro, países de origem anglo-saxônica celebram o Halloween, conhecido no Brasil como a Festa das Bruxas. Dentre as diversas atividades e rituais associados a essa tradição de origem pagã está o chamado trick-or-treat. Consiste basicamente em crianças fantasiadas de bruxas, magos, fantasmas e criaturas afins saírem pela vizinhança batendo de porta em porta solicitando guloseimas (treats) como balas e chocolates - no que são normalmente atendidas por moradores gentis e devidamente preparados para a ocasião. Caso não o sejam, as crianças respondem à recusa com algum tipo de travessura (trick), tal como jogar ovos nas janelas ou amarrar rolos de papel higiênico nas árvores.

Pois, ano após ano, reaparecem em jornais e TVs relatos em que "alguma coisa deu errado" - a travessura vindo antes de adolescentes ou adultos mal-intencionados do que propriamente de crianças brincalhonas. Agulhas, lâminas de barbear, cocaína e veneno são alguns dos corpos estranhos que vêm parar dentro de inocentes balinhas e bombons. Se o Halloween é uma festa das bruxas, estas são encarnadas aqui por ameaças muito mais concretas (e aparentemente banais) do que quaisquer outros sustos que a simbologia em torno de criaturas sobrenaturais possa causar. 
Foi assim que, de $1^{\circ}$ a 3 de novembro de 2005, Brian Chapman enviou à lista de discussão uma séria de cinco mensagens - duas delas intituladas Halloween surprises e as demais More Halloween surprises, Yet even more surprises e More surprises - , cada uma contendo uma mini-coletânea de clipes de artigos publicadas em jornais dos Estados Unidos e Canadá com os devidos links de acesso. Nesses artigos, lemos sobre as seguintes “surpresas”, ou variações sobre o mesmo tema, pela ordem:

- Numa província do nordeste do Canadá, um garoto de cinco anos recebeu um doce contendo uma lâmina de barbear de aproximadamente três polegadas de comprimento (www.canada.com).

- Em Powhatan Point, West Virgínia, uma criança encontrou uma pequena agulha dourada dentro de uma mini-barra de chocolate (www.news-register.net).

- Em Winnipeg, uma garota de 12 anos teve a língua perfurada por uma pequena agulha inserida no mini-pirulito recheado de chocolate que acabara de comer (http://winnipeg.cbc.ca).

- Em Calgary, crianças vestidas de fantasmas e duendes receberam, em meio aos usuais doces, pequenos sacos de plástico contendo fezes (http://calgary.cbc.ca).

- Em Lincoln, Nebraska, uma avó de 68 anos mordeu uma mini-barra de chocolate, recebida naquela noite por um de seus netos, com uma agulha de costura de uma polegada dentro (www.journalstar.com).

- Em Ambridge, Pennsylvania, um garoto de cinco anos, acompanhado de sua irmã, recebeu de um casal conhecido uma lâmina descartável coberta por uma embalagem protetora (www.timesonline.com).

- Em Dayton, Ohio, uma garota encontrou fezes, provavelmente de um animal, na sacolinha de doces que um simpático senhor lhe oferecera enquanto caminhava por uma rua (www.whiotv.com).

- Em Lehi City, Utah, a polícia investiga um incidente em que um frasco contendo uma pequena quantidade de cocaína foi encontrado entre os doces de uma criança (www.sltrib.com).

- Em Streetsville, Ontário, um garoto de 12 anos ficou chocado ao se deparar com uma ratazana de plástico presa a uma ratoeira de verdade entre os itens de sua sacolinha de guloseimas (www.mississauganews.com). 
- Em London, Ontário, a polícia investiga dois casos isolados: uma criança encontrou um comprimido de droga controlada entre seus doces e outra foi recebida por um morador exibicionista nu (um flasher) (www.lfpress.ca).

- Em Erie, Pennsylvania, uma menina de 8 anos encontrou, em meio aos itens de sua sacolinha, uma embalagem plástica tipo ziplock e uma caixa de balas ambas contendo pedaços de fezes de gato (www.35see.com).

- Em Vernon, British Columbia, uma criança encontrou uma agulha de costura escondida em um copinho de pasta de amendoim cujo selo de proteção havia sido visivelmente violado (www.canada.com).

Uma sucessão de relatos como esses sugere, numa primeira leitura, que, se a contaminação proposital de doces na época do Halloween é um mito - cuja matriz ou imagem prototípica é a da presença (jamais “documentada”) de lâminas de barbear em maçãs (Vos 1996; Ellis 2001; Brunvand 2002) -, este mito tornou-se realidade. Teríamos aqui uma das três formas que o sociólogo Jean-Bruno Renard identifica como geradoras de uma lenda urbana: a reconstrução, ou reelaboração, de um evento já presente no imaginário coletivo (1994: 101-109) ${ }^{56}$. A reconstrução, no caso, se daria sob a forma de uma ação intencional, ou ostensão (ver Capítulo 4, seção 2.1), que transforma uma ameaça presente em relatos já antigos sobre Halloween - remontando pelo anos à década de 1950 - em acontecimentos dos do tipo reportados em fait divers.

Mas os relatos em questão não parecem ser interpretados pelos membros da lista simplesmente em termos de "mito versus realidade". Dúvida e ambivalência dão o tom das mais de 30 mensagens que se seguem. Michelle inaugura a discussão questionando a plausibilidade de uma criança aceitar doces de um homem andando na rua, como no relato de Dayton, Ohio. Acredita tratar-se provavelmente de um trote armado por um parente ou pela própria criança. No entanto, como saber a verdade, questiona ela, senão acompanhando o noticiário local ao longo dos dias? Talvez uma notinha aqui ou ali ainda se publique "re-instaurando a realidade" - mas o efeito mítico, este se perpetua.

\footnotetext{
${ }^{56}$ As outras duas formas pelas quais as lendas urbanas se originam, segundo o autor, são: ampliação ou exagero de um fato real - por exemplo, a notícia de uma morte acidental transformando-se numa lenda que estigmatiza as circunstâncias e/ou o local onde a morte aconteceu - e deslocamento de contexto de um fato real - por exemplo, crimes como seqüestros e assaltos originando lendas que alertam para o riscos de supostos crimes de natureza similar. No entanto, a meu ver, a classificação do autor está longe de dar conta de todas as lendas, sua "gênese" sendo freqüentemente indeterminada ou o resultado da combinação de elementos dessas três formas.
} 
Se tal leitura se sustenta, a suposta oposição entre o "aconteceu de verdade" e o "foi tudo invenção” perde qualquer sentido prático. Quando, de um lado, Scott Smith diz que tais anedotas, repetidas de segunda, terceira e quarta mãos, acabam sempre provando ser "farsas, mentiras e reações exageradas" e, de outro, Roiz afirma que tais ameaças, embora raras, "são reais e acontecem", eles não me parecem estar de forma alguma polarizando um debate. Quer se leve este ou aquele argumento em consideração, ambos corroboram uma outra "verdade": a de que as lendas urbanas têm um poder regenerativo que lhes é constitutivo, e que se manifesta em sua eterna reativação, em locais os mais diversos - mas especialmente e, particularmente neste caso, com data e hora previstas.

A forma jornalística com que são revestidos tais textos não garante absolutamente nenhum tipo de facticidade comprovada. Quer dizer, qualquer facticidade em torno dos relatos torna-se secundária na medida mesma em que (1) os relatos seguem "desprovidos" de um desdobramento dos incidentes - pelo menos do ponto de vista dos não "diretamente envolvidos" -, tendendo a se perder numa rede de informações e novidades que se suplantam

umas às outras continuamente e (2) os relatos valem pela "confirmação renovada" - no sentido de uma nova formatação - de um evento-surpresa que nunca é tão surpresa assim, pois está sempre-já assentado num imaginário recorrente e devidamente "aguardado" em determinada época do ano.

Mas o debate continua, e levanta-se ainda um outro argumento: sendo os relatos verdadeiros ou não, a crença em sua plausibilidade contribui, segundo Scott Smith, para reforçar um medo injustificado dos nossos vizinhos. A não ser que tenhamos evidências concretas de que nossos vizinhos querem deliberadamente nos fazer mal - e não simplesmente "pregar uma peça", o que afinal faz parte da própria tradição de rituais (basicamente inofensivos) em torno do Halloween - não deveríamos sair por aí acreditando em qualquer notícia sensacionalista, alimentando uma paranóia cujos efeitos silenciosos se manifestam já numa resistência a qualquer contato minimamente mais próximo com os que nos cercam. Como Rochelle Canfield, uma outra participante, questiona: "Whatever happened to common sense, parental supervision and neighborhoods where everybody knows everybody else?"

A dificuldade do argumento de Smith, no entanto, está na insistência em se obter provas, dados concretos, informações mais precisas sobre os incidentes. Estes 
dificilmente serão encontrados em relatos do tipo discriminados anteriormente. Detalhes de como alguém consegue colocar uma agulha dentro de um doce duro como um pirulito - "There's a trick the best magician couldn't perform”, como sugere Rich, mais um participante - são devidamente omitidos, ou sequer questionados, nessas narrativas. Ocorre ainda uma espécie de efeito conspiratório de apagamento da memória: as crianças não conseguem lembrar, por exemplo, exatamente em que casa obtiveram os objetos-surpresa. Assim, quase invariavelmente, os supostos vilões da história permanecem anônimos, não-identificados, sendo representados apenas pelo estereótipo do vizinho abusivo e mal-intencionado - um “outro” que é o verdadeiro fantasma do Halloween.

Para os que discordam de Smith, o argumento mais persuasivo é, pois, de que não se deve esperar o grito de Fogo! para se abandonar o recinto. O universo das lendas urbanas é esse que busca sempre “fisgar suas vítimas”, pegá-las - potencialmente, qualquer um de nós - desprevinidas. Segundo Roiz, é claro que relatos de envenenamento ou manipulação de doces no Halloween são inspirados em velhas histórias de lâminas em maçãs e outras afins (o imaginário reconstruído, retomando o termo de Renard). Mas, argumenta ele, hospitais continuam incluindo raios-X de doces entre seus serviços rotineiros, agentes públicos continuam emitindo alertas de segurança com certa regularidade, e estatísticas ainda posicionam os (raros) incidentes como ameaças reais.

E, finalmente, mas não de forma menos significativa, jornais e noticiários de TV continuam vendendo histórias como essas, pois é de material de tal natureza que um bom número desses meios de comunicação sobrevivem. Culpar a mídia sensacionalista por não seguir obstinadamente em busca de esclarecimentos, retratações e estatísticas significa perder de vista o caráter mítico-fantasístico das “ficções reais” que alimentam o tecido do cotidiano, quer nos jornais, quer na TV, quer na conversa de bar.

Essas “ficções reais”, podemos já concluir, reforçam a teia de interdiscursos que sustenta uma cultura do medo a qual nenhuma racionalidade consegue efetivamente dissipar. Elas engrossam, enfim, um arquivo de narrativas cujos traços emergem a cada ciclo, apagando-se só provisoriamente até que novas marcas venham a eles se sobreescrever. Um jogo potencialmente infinito de relançamentos que constitui a própria tensão entre o já-marcado e o ainda-por-marcar, ou o velho - repetido, mas não o mesmo - e o novo - único, mas não absolutamente original. Um jogo motivado por uma 
falta constitutiva, uma falta que nunca se completa, e em pelo menos dois níveis: uma falta que se manifesta tanto no desejo de atingir uma verdade final que nunca chega, por mais que se possam produzir efeitos de facticidade e racionalidade objetiva em torno dos relatos, quanto no impulso - oposto àquele apenas na superfície, visto que é um seu suplemento - de investir na ficção, de contar e ouvir histórias perturbadoras, e acreditar (ou não) nelas, como uma forma de elaborar discursivamente uma experiência cotidiana que nos confronta com ameaças mais ou menos difusas, mais ou menos “reais”. Eis, enfim, o jogo que a dinâmica de nossas narrativas urbanas contemporâneas, pelas múltiplas práticas que a envolvem, acaba por materializar. 


\section{CAPÍTULO 6: Lendas Urbanas como Construções do Outro}

“E o problema é que esse 'outro', numa sociedade em que a identidade torna-se, cada vez mais, difusa e descentrada, expressa-se por meio de muitas dimensões. O outro é o outro gênero, o outro é a cor diferente, o outro é a outra sexualidade, o outro é a outra raça, o outro é a outra nacionalidade, o outro é o corpo diferente."

- Tomaz Tadeu da Silva, Identidade e Diferença, 2000

"O Outro é o que me dá a possibilidade de não me repetir ao infinito.” - Jean Baudrillard, A Transparência do Mal, 1990

"Dada a intensidade do medo, se não existissem estranhos eles teriam que ser inventados.”

- Zygmunt Bauman, Comunidade, 2003

A questão do outro tem surgido, de modo mais ou menos explícito e em diferentes níveis, ao longo deste trabalho. Ela aparece, primeiramente, na tentativa de definição do gênero lenda urbana, na medida em que se constitui como uma intersecção com outros gêneros, confundindo-se com estes ou combinando-se a eles em textos de natureza heterogênea. Isso torna-se mais evidente quando se toma a lenda urbana como uma prática discursiva multifacetada, que não se encerra em um texto que contém a lenda, mas antes relaciona esse texto a tantos outros que com ele compõem uma cadeia interdiscursiva - incluindo acréscimos, comentários, refutações e outras respostas (ou atitudes responsivas, nos termos de Bakhtin) que aí se interpõem.

A questão do outro aparece também, como vimos especialmente no capítulo anterior, no modo como narrativas arquivadas são reelaboradas, retomadas, reativadas numa rede de memória. O outro é o mesmo reencenado; o outro é o evento que desloca a estrutura, tanto no sentido de contestá-la como no de reafirmá-la, reforçar suas fronteiras (sempre e por constituição) fluidas. Quando somos tentados a perseguir os rastros deixados por narrativas anteriores nas narrativas que se nos apresentam para análise no "presente”, buscando suas origens, remontando suas filiações longínquas, ou mesmo mapeando sua variabilidade inevitável ao longo do espaço e através dos diversos contextos sócio-históricos de sua produção/circulação, estamos, em última análise, buscando entender o outro. Estamos buscando restituir às narrativas o que é próprio seu, em vista daquilo que jamais pode ser totalmente seu, ou seja, jamais totalmente original. 
Com um olhar para o que elas apresentam de novo e outro buscando identificar uma matriz supostamente originária, comum e universal, somos confrontados com uma relação de suplementaridade que está, afinal, na base de qualquer forma de discurso.

O outro, enfim, constitui o mesmo não como simplesmente uma presença explícita marcada na superfície do discurso, mas antes como uma falta constitutiva. No espaço discursivo, o outro não se manifesta necessariamente na forma de uma citação ou fragmento localizáveis - como nos discursos direto e indireto -, ou como uma entidade exterior que irrompe no discurso "forçando" a quebra de uma suposta homogeneidade - um gênero se misturando a outro, por exemplo. Não há a necessidade de uma ruptura visível para que se identifique aí a presença do outro. Como bem sintetiza Sírio Possenti:

“O Outro encontra-se na raiz de um Mesmo sempre já descentrado em relação a si próprio, que não é em momento algum passível de ser considerado sob a figura de uma plenitude autônoma. O Outro é o que faz sistematicamente falta a um discurso e lhe permite fechar-se em um todo. É aquela parte de sentido que foi necessário que o discurso sacrificasse para constituir sua identidade - e cujos elementos nunca são tomados, ou retomados, a não ser como simulacros.” (Possenti 2004: 384)

Em última análise, o outro representa a própria condição de possibilidade do discurso, o qual só se permite fechar em uma positividade/regularidade mediante o "esquecimento" dessa outridade que lhe constitui.

Neste capítulo final, proponho olharmos para a questão do outro de um ponto de vista bastante específico. Buscarei investigar as diversas formas sob as quais o estrangeiro, o estranho, o diferente é personificado nas lendas urbanas. Vimos em capítulos anteriores como a vida urbana cotidiana, a tecnologia, a comida e a doença constituem-se como verdadeiros “outros”, cuja presença ameaçadora se projeta assumindo formas materiais diversas, em relatos não muito distintos entre si em sua apresentação básica. São esses “outros” que os relatos, com sua vocação de urgência e pânico, buscam expurgar, exorcisar. O outro em que me concentro agora é o outro personificado, o outro da identidade outra: o imigrante ilegal, o americano, o chinês, o mexicano, o terceiro-mundista. Trata-se do sujeito que, como qualquer outro sujeito, 
tem sua identidade construída de modo relacional, pela alteridade (o outro me constitui). É o sujeito que só adquire uma unidade por meio da enunciação, isto é, por meio da performatividade narrativa que enuncia/anuncia as relações de alteridade e estranhamento que contribuem - sempre a partir de valores locais e contextualizados para a constituição, e permanente reelaboração, do que chamamos identidades. No caso aqui (mas não somente), identidades nacionais.

Para entendermos melhor o funcionamento desse processo de construção de identidades, embarquemos em algumas conexões ao longo do corpus.

\section{A Conexão Mexicana}

Diz a lenda: uma mulher norte-americana de férias em Acapulco, nadando certo dia em uma praia deserta, depara-se com um simpático cãozinho Chihuahua, a quem, por não ter dono, decide levar ao hotel e alimentar. O tempo passa e o animal, silencioso e dócil, acaba ficando ali, no hotel, até o final da permanência da mulher no México. Chega a hora de voltar para os Estados Unidos e a mulher resolve levar a criatura junto escondendo-a na bolsa como a um objeto contrabandeado. Ela passa ilesa pela alfândega e durante todo o trajeto. De volta a seu país, mantém o bichinho por um certo tempo em seu apartamento, sem reclamações de vizinhos ou qualquer outro tipo de problema. Até que um dia, ao retornar para casa do trabalho, descobre que o animal havia caído dentro do vaso sanitário. Resgata-o, mas, temendo algum tipo de doença, leva-o a um veterinário, que, para seu choque, sentencia: "O que a Senhora tem aqui não é um Chihuahua, e sim uma ratazana d’água mexicana!”. Essa é talvez a versão mais conhecida de The Mexican Pet, uma das lendas urbanas mais citadas em compilações e publicações sobre o gênero (Vos 1996; Brunvand 2002; e outros).

Como já poderíamos antever, trata-se de uma narrativa cuja simbologia se apresenta de modo bastante evidente: a ameaça, o “outro”, aqui mexicano, entra em nosso território clandestinamente, mas por nossa responsabilidade. Então, devemos agora pagar pelas conseqüências de acreditar na suposta inocência e fragilidade de uma criatura que, na realidade, representa um perigo à nossa própria segurança e integridade física. Enfim, trata-se de uma besta feroz escondida sob a aparência enganadora de fragilidade. Também como já poderíamos prever, tal história adquire versões distintas 
em momentos e locais diferentes: em uma destas, a criatura é trazida por nova-iorquinos em férias na Flórida (começo dos anos 1990, época de grande fluxo de imigrantes haitianos à região); em outra, por ucranianos em férias no Paquistão (meados dos anos 1990). De fato, há registros de versões em que as ratazanas são “identificadas” como originárias de lugares tão distantes entre si quanto a Austrália, a Coréia do Norte, a Bélgica, a Turquia e a Guatemala (www.snopes.com; http://urbanlegends.about.com).

Seja qual for a versão, estamos diante de uma modalidade de narrativa que parece ganhar fôlego renovado a cada nova “crise de imigração” mundial. Se isso se comprova, temos motivos suficientes para crer que histórias como essa mantêm sua popularidade em plenos anos 2000. No momento de escrita deste trabalho, por exemplo, um muro fortemente monitorado ameaça ser erigido entre os Estados Unidos e o México para impedir, com o auxílio da mais avançada tecnologia, a entrada ilegal de imigrantes deste país para aquele. Afinal, vem do México aproximadamente $50 \%$ do contingente de “outros” que se aventuram a cruzar as fronteiras físicas - e culturais - de uma América mais ao sul para uma América mais ao norte. É essa conexão mexicana que passo a explorar agora.

Uma busca em nosso corpus de pesquisa nos revela um número considerável de entradas em que figuram as palavras Mexico ou Mexican. A primeira delas, postada por Anna Sunshine Ison em 4 de janeiro de 2005, toma como ponto de partida um link enviado anteriormente por Brian Chapman dando conta de um possível roubo de órgãos de iraquianos por parte de soldados do exército norte-americano. Trata-se de mais um clássico das lendas urbanas: vilões americanos saem pelo Terceiro Mundo roubando órgãos para comércio ilegal. Anna aponta para a presença maciça dessa narrativa tanto no que chama de "alta” como de "baixa cultura”, e diz-se feliz por ter encontrado em um filme que acabara de comprar um exemplo de confluência de dois de seus passatempos preferidos: lendas urbanas e filmes de luta mexicanos. No filme em questão, chamado Santo en la frontera del terror, o famoso luchador oferece proteção a um imigrante ilegal contra o diabólico Dr. Sombra, que rouba e vende órgãos de imigrantes para um hospital na cidade de McAllen, no Texas.

Dois meses depois, em 8 de março, Barbara Mikkelson encaminha a mensagem de uma leitora de Snopes que questiona se é ou não lenda urbana um relato que lhe havia sido feito. Um bombeiro que anos antes trabalhava em Los Angeles havia sido chamado para apagar um fogo em um apartamento. Depois de fazê-lo, entrou no 
apartamento e encontrou vários extintores espalhados pelo local. Ocorre que o morador, quando estava se mudando para lá, viu um extintor do lado de fora e perguntou a um vizinho para que servia. O vizinho lhe deu a resposta óbvia de que se tratava de um extintor e que ele poderia usá-lo para apagar incêndios. Quando então ocorreu o fogo no apartamento, o morador correu para pegar um extintor e arremessou-o para dentro do local. Como isso não surtiu o efeito desejado, buscou outro e mais outro extintor, arremessando-os todos da mesma forma. Ele era mexicano.

Enquanto um ou outro membro da lista entra em longos esclarecimentos técnicos quanto ao uso inadequado de extintores e explosões resultantes, o detalhe étnico não passará despercebido. Nem poderia. Estée (hepatterson) comenta: “Judging by what some of my clients (I work with immigrants) have done in the past, it wouldn't surprise me in the least." Theresa Burch, como ex-bombeira, conclui: "Yes, people can be that dumb.” Sim, pessoas podem ser incautas, ou burras, mas não se trata aqui de pessoas quaisquer, qualquer um de nós.

Ainda que contado como possivelmente verdadeiro, o relato dialoga de forma muito próxima com um sub-gênero de piadas étnicas em que os traços de burrice “típicos” de uma determinada nacionalidade aparecem de forma explícita, como fonte do humor (ver seção 2 abaixo). O que o relato acaba por fazer - ainda que não seja essa sua “intenção principal” - é reforçar o estereótipo de que latinos são ignorantes, seja porque não entendem a língua dos nativos norte-americanos, seja porque ficam confusos com a operacionalidade das “coisas modernas”. Sobretudo, está em jogo nessas narrativas o efeito de uma rígida alienação da alteridade. Como bem define Souza, o estereótipo é uma forma de representação que rejeita a alteridade no próprio processo de construção da identidade de um grupo ou nação. Nos dizeres do autor, o estereótipo “nega o jogo da diferença presente no processo relacional da construção da identidade e, com isso, nega a necessidade da alteridade e do hibridismo na construção da identidade, pressupondo que haja identidades puras, não-híbridas” (2004: 123). No nosso caso aqui, o mexicano é esse outro, esse “ele” que não pertence, não se encaixa no universo do “nós”, não porque seja simplesmente diferente, mas porque é inferior num raciocínio que diz que a diferença do “eles” só pode ser vencida pela assimilação ao mesmo do "nós", ou seja, pela conversão ao universo de valores e referências que compõem o supostamente homogêneo “nós”. 
Mas essa discussão merece um desenvolvimento maior. Proponho, por ora, que retomemos nosso itinerário. Na mesma Los Angeles daquela “anedota inocente”, algo mais “ameaçador” ocorreu dois meses depois, por ocasião do feriado nacional mexicano de Cinco de Mayo. Segundo reportagem da NBC 4-TV intitulada "Black Leaders Call On Feds To Probe Internet Rumor About Racial Attacks”, um rumor propagado por email alertava para um possível ataque racial de hispânicos a negros nas escolas da cidade no dia do feriado. Sem querer alimentar mais alarmismo, líderes negros locais pediam uma investigação federal sobre o caso, que teria mantido dezenas de milhares de alunos (um índice de ausência de aproximadamente 18\%) em suas casas, com medo do que a reportagem chamou de "terrorismo na comunidade". O rumor provava, porém, não passar de uma farsa (hoax).

Ora, uma questão logo nos chama a atenção. Se se trata de uma farsa, se não há afinal nenhuma "guerra racial" - "I don't care what your objective is. Please stop doing it. There is no racial war that is about to occur", como diz David Hurn, líder negro de uma escola estadual -, por que a palavra "terrorismo" haveria de ser usada por uma fonte por princípio imparcial de informação que é a de um artigo impresso? Qual a diferença entre um caso real com jeito de piada (como o do incêndio) e um rumor falso noticiado com alarmismo por um órgão de imprensa? A julgar pelo efeito sintomático de uma relação de alteridade/estranhamento "mal resolvida”, ambos parecem cumprir uma função similar: o de fomentar a lenda, reforçar o estereótipo de que o outro étnico representa fundamentalmente uma ameaça. E o que é particularmente significativamente neste caso específico: trata-se de uma ameaça dirigida a uma comunidade já por si só outra, a de minoria negra norte-americana, que, no entanto, possui articulação políticocultural consolidadas, com entidades e conselhos que lhe são porta-vozes e cujos direitos estão sempre alertas para defender. Como David Hurn faz questão de salientar, o prejuízo recai sobre aqueles que são os “nossos futuros líderes”. Entretanto, se, pelo comentário, subentende-se que também os jovens latinos se incluem na denominação auspiciosa de "futuros líderes", a absoluta ausência no artigo de qualquer escuta (na forma de testemunho, declaração, “direito de defesa”) dessa outra parte do rumor nos deixa com sérias dúvidas sobre o verdadeiro estatuto de pertencimento desses últimos. Dentro dessa lógica, caberia se perguntar: terão, mesmo, os latinos os mesmos direitos? Ou estarão eles ocupando, provisoriamente, a posição de outros dos outros? Um rumor 
só, certamente, não nos dará “a” resposta. Funcionará, talvez, como sintoma de uma tensão latente na sociedade americana.

Em julho, Theresa Burch envia um relato, sem fonte definida, sobre o qual não conseguira obter maiores detalhes. Segundo ela, motoristas de caminhão têm retornado de Laredo, Texas, contando a história de um guia que levava turistas americanos ao México para passeios a pé partindo de uma parada de caminhões local. Depois de encontrar os corpos de alguns desses turistas americanos jogados em caçambas, a polícia concluiu que o guia atravessava a fronteira com eles para cometer os crimes. Pat Chapin, moradora do Texas, esclarece que rumores desse tipo são recorrentes em praticamente cada trecho de fronteira entre os dois países, mas que nunca os tinha ouvido envolvendo motoristas de caminhão. Ela acrescenta que na época havia um problema no trecho da fronteira de Brownsville e El Paso em que corpos de mexicanos estavam sendo encontrados em caçambas e porta-malas de carros, mas as mortes aparentemente se relacionavam ao comércio ilegal de drogas na região. Acredita serem incomuns casos envolvendo grupos de turistas, já que os crimes chamariam muito a atenção. Joe Yuska suspeita ainda mais da possibilidade, e admite: não consegue visualizar turistas americanos seguindo um guia em uma parada de caminhões no México. Ao menos não pelo que "nós esnobes almofadinhas do leste (us effete eastern snobs) sabemos sobre o México”.

E o que é que os americanos do leste sabem sobre o México? Talvez não muito. Quanto menos se conhecem as condições reais em que os locais vivem e como eles efetivamente se relacionam com turistas, mais simples é acreditar no lado sombrio e ameaçador do imaginário sobre o outro. Porém, Pat Chapin, mais uma vez falando a partir desse entre-lugar, nos traz alguns esclarecimentos: há nativos que se autoempregam como guias informais, vestindo uniformes que se confundem com os de policiais, mas cujo trabalho se concentra em orientar turistas a pontos de compras, indicar locais onde encontrar prostitutas ou quaisquer outros em que se tenha interesse. Quanto mais turistas em um grupo, mais dinheiro esses nativos ganham. Embora possam eventualmente sacar uma faca - mexicanos, ela acrescenta, normalmente não têm licença para portar armas - esses guias informais não teriam nenhuma motivação concreta para fazê-lo. Assim, conclui Chapin: "[T] his is the same tired old 'if you go to Mexico you will get killed for whatever is in your wallet' thing”. Pelo menos é isso que 
alguns daqueles “esnobes almofadinhas do leste” - do oeste, do norte e de tantas outras esquinas - insistem em (ou preferem) acreditar.

Quando, em maio de 2006, manifestações na Califórnia a favor dos direitos dos imigrantes latinos nos Estados Unidos tornaram a esquentar o debate em torno do problema, mais uma oportunidade se apresentou para a reciclagem de velhas lendas sobre o estrangeiro preferencial. No dia 6 daquele mês, Smitty acende a primeira chama de um alentado debate a ser referido sob o título de California Situation. Reproduzo a mensagem, um tanto desconexa, em seu formato original:

You have to live in California to really know what is going on and what has been going on....the demonstrations only opened the silent majority's eyes of the arrogance and depth of this problem and the Mexicans...do not blame the other foreigners...they do not have a proliferation of making babies.....you just have to see it...

you see the healthcare.....citizens who work and have no health insurance are screwed but the mexicans are not cause they make babies and they have to be delievered and cared for after they are born..today's price, $\$ 1100$ per family, plus food stamps $\$ 400$ per head, plus WIC (milk and formila and pampers) and FREE MEDICAL..............

AND THEY HAVE THE ARROGANCE TO WANT THEIR LANGUAGE THEIR RIGHTS AND SING THE NATIONAL ANTHEM WITHOUT PERMITS TO EVEN BE HERE IN SPANISH...

that is extreme propaganda which I beleive in the end will bite them back in the ass.

THEY FORGOT ONE SMALL PART OF THE EQUATION I TOLD YOU....

THE AMERICANS ARE NICE ,. BUT NOT SO STUPID...

AND THEY HATE GETTING THREATENED BY ANYONE...IT GETS UP THEIR LEFT NOSTRIL....ESPECIALLY AFTER THEY THINK THEY HAVE BEEN SO NICE AND ACCOMMODATING TO YOU...AND AFTER A WHILE...THEY KICK ASS AND COME BACK WITH A VENGEANCE SO YOU WILL THEN KNOW WHO AND WHAT IS MEANS TO BE AMERICAN........

TRUE OR FALSE..???

We have 11 hospitals close down in Los Angeles County including Martin Luther king which served the black community since it was raised from the ground....even the blacks did not run the well that dry!!! AND THEY ARE AMERICANS!!!!! 
Num primeiro momento, salta aos olhos o tom raivoso e indignado da mensagem. O uso extensivo de letras maiúsculas e pontuação dramática ressaltam o tom passional do autor, que parece estar fazendo um desabafo sob a forma de um testemunho pessoal. Destaca-se, no entanto, a pergunta lançada quase ao final do texto: “TRUE OR FALSE..???”. A que ela estaria se referindo? À tudo que se vem dizendo até então? Ou especificamente à descrição do they feita no parágrafo anterior? Aliás, a quem se refere esse they? Aos americanos? Aos mexicanos? Uma leitura baseada na simples coesão textual nos autoriza a pensar que pode-se estar falando tanto de uns quanto de outros. A julgar pelas mensagens que imediatamente se seguem, não será em “pormenores” como esses, no entanto, que o debate irá se travar.

As duas primeiras reações à mensagem de Smitty são sucintas, e igualmente emocionais. Roiz sugere que a pessoa está na sala de discussão errada: a KKK (Klu Klux Klan) é no final do corredor... à direita. Pat Chapin concorda plenamente, e pede para que Smitty mantenha o dedão (ou seja o que for) longe das letras maiúsculas... mesmo se aquele fosse um local designado para tal discussão, ainda assim o autor da mensagem não o estaria fazendo de modo adequado. Pat acrescenta ainda que não é preciso viver na Califórnia para saber o que está acontecendo. Michael Rohaly tenta argumentar que a mensagem oferece uma chance para se discutir certa propaganda política atual, e menciona a declaração do presidente Bush alguns dias antes segundo a qual todas as pessoas que quisessem se tornar cidadãos americanos deveriam aprender inglês e cantar o hino daquele país em inglês. Roiz, no entanto, reafirma sua posição: ele e os demais estão em um grupo de discussão chamado UL, e isso quer dizer "Urban Legend”. Não estão interessados em propaganda ou quaisquer editoriais políticos que as pessoas queiram despejar. Para isso, há muitos outros grupos de discussão. Mas Rohaly insiste em seu raciocínio, defendendo que se deve corrigir uma falsa concepção, corrente na época, de que hinos cantados em espanhol estariam ultrajando todos os pensadores de direita americanos. Além disso, lembra ele, no próprio Snopes é possível encontrar uma página dedicada a citações de líderes hispânicos supostamente feitas na época e que na verdade datavam desde pelo menos a década de 1990.

O debate prossegue, porém, evadindo a questão da situação californiana em si e concentrando-se no estatuto do texto, isto é, no direito de pertencimento ao fórum de uma mensagem como a de Smitty. O estranhamento inicial provocado pela ausência de uma fonte ou referência faz alguns membros da lista questionarem se se trata de algo a 
ser combatido, desbancado (para Roiz, o objetivo principal da lista), ou se, ao contrário, deve ser tomado como expressão direta de um pensamento partidário e (para muitos) ofensivo. Neste caso, o texto seria um “estranho no ninho”.

Mas como parece in(de)terminável a discussão sobre qual afinal é o propósito da lista, e o que as pessoas estão lá para fazer, mais uma vez entra em cena a moderadora. Barbara parte de uma citação de Marc Alberts, que, ao contrário de Roiz, acredita que a lista existe para discutir as coisas, não simplesmente desbancá-las. Para Alberts, discutir mitos não equivale a propagá-los como fatos. O que Barbara questiona, entretanto, é a natureza do que está sendo discutido. Uma verdadeira discussão sobre por que se crê nos rumores com tão pouco questionamento, e por que a atual controvérsia sobre a imigração mexicana se reflete nas histórias que ouvimos e nos e-mails que recebemos de pessoas que nos são próximas, é certamente bem-vinda. Já uma discussão sobre se os mexicanos deveriam ter permissão de entrar em território americano, se hispânicos estão se apoderando de terras nos Estados Unidos, ou se a imigração ilegal é boa, má ou perdoável, caberá melhor em outras listas. E ela aproveita para lembrar, mais uma vez: “[W]e're here to discuss folklore, to study where various tales come from and how they've changed over the years, to examine how society is reflected in its stories, to look at what our stories say about us, about the people who tell them."

Se levada a fundo essa última proposta, no entanto, haveremos de nos perguntar por que um texto expressando uma posição tão radical, tão politicamente incorreta, foi capaz de gerar tamanho desconforto entre os membros da lista. Poderíamos arriscar a interpretação de que o texto primeiro (“original”), tendo sido lançado na ordem do discurso de modo um tanto violento - isto é, não-conforme às regras de uma comunidade supostamente habituada a seus parâmetros, supostamente certa de sua identidade -, acaba por lançar um elemento de alteridade ameaçadora que de certa forma ecoa aquela exorcisada em seu próprio conteúdo: a lembrar, a ameaça mexicana. A mensagem de Smitty grita na voz desconexa, raivosa e por que não dizer radical de um sujeito (nação?) em crise explícita de identidade. Quer dizer, ouvimos aí a voz de um “nós” que se apega aos últimos estertores de uma identidade que já há muito não é homogênea (nunca foi), posto que atravessada por esses e outros tantos “eles”. Se levada a fundo a proposta da moderadora da lista, haverá de se reconhecer que folclore pode, sim, dizer muito sobre quem o discute e o propaga. Os membros do fórum, supostamente mais esclarecidos sobre os efeitos do folclore sobre as crenças e discursos 
das sociedades contemporâneas, têm, eles mesmos, de dar conta de uma exterioridade agressiva, uma exterioridade radical com a qual é difícil se identificar, mas que não deixa de projetar um "outro" dentro de um "mesmo" - sendo ela portanto uma exterioridade (alteridade, estranhamento) que se encontra sempre-já dentro de nós (eles) mesmos. Como bem a propósito diria Julia Kristeva: “[O] estrangeiro está dentro de nós. Quando fugimos ou lutamos contra o estrangeiro, nós estamos lutando com nosso inconsciente - aquela faceta 'imprópria' do nosso impossível 'único e próprio’” (1991: 191).

Enfim, se levada às últimas conseqüências, a questão da ameaça mexicana coloca a todos que se confrontam com seus discursos o desafio de descobrir sua própria e perturbadora outridade, "pois é isso o que de fato eclode no confronto com aquele ‘demônio’, aquela ameaça, aquela apreensão gerada pela aparição projetiva do outro no coração daquilo que insistimos em manter como um próprio e sólido 'nós"' (Kristeva 1991: 192). Se é nas práticas discursivas que os demônios são enunciados, tomando corpo e assumindo identidades, também deverá ser por meio dessas práticas que se abrirá um espaço possível para a negociação e, por que não dizer, “exorcisação” de tais demônios.

\section{Imigrantes Ingratos, Americanos Estúpidos}

Mas, é claro, os mexicanos não estão sozinhos na posição de outros. Não poderiam os americanos ser, eles próprios, outros de outros?

Uma onda de antiamericanismo mais ou menos generalizada vem se reforçando nos últimos anos motivada pelas políticas externas dos Estados Unidos, particularmente sua atuação no Iraque. Uma mensagem enviada em 12 de janeiro de 2005 por Brian Chapman nos remete a um exemplo que ilustra bem o sentimento corrente à época. Um e-mail indignado, assinado pela irmã de um jovem fuzileiro naval americano no Iraque, estaria circulando na Internet relatando a recusa de um funcionário de uma loja de conveniência em Fort Worth, Texas, em atender o rapaz por este estar trajando uma camisa da Marinha Naval dos Estados Unidos. Segue o e-mail original: 
Subject: Marine refused service at local store

Thought I would pass this along.

On December 19th, 2004, my brother Jason F. Young Lance Corporal in the United States Marines was refused service at a convenience store named One Stop Grocery and Grill at 2001 8th Ave. in downtown Fort Worth, Texas.

He was refused service because he is a Marine.

He went in to the store and asked the clerk (a man of middle eastern descent) for a can of tobacco, at which point the clerk asked him if he was in the military. (He had on a USMC shirt) After my brother replied, "yes sir" the man said nothing to him and looked at the other middle eastern man in the back of the store. Then both men proceeded to go in to the storeroom and did not come out. My brother yelled back to them a time or two and they did not respond.

Jason waited a few minutes and finally left the store.

I am very proud of the way that my brother reacted to the situation. I can honestly say if it had been me I would have cleared their counter and taken my can of tobacco. It is not fair that these people come into our country and enjoy the freedoms that my brother and so many others have fought for. They do not respect our service men and women who have died for them to be able to be here. They do not respect our country, and personally I think they need to go back to where they came from.

My main point in writing this is to get the word out about this particular store and discourage people from shopping there. If they can't respect or even sell to the people that are responsible for the rights they have, then they don't deserve to be in business.

Please email this to everyone you know to discourage them from shopping at this store.

Heather M. Dowell

O relato, noticiado com certo destaque pela imprensa, provou ser verdadeiro. Mas, segundo artigo no site da transmissora local da rede de TV NBC, ainda que (confirmada a versão) o funcionário em questão tenha sido imediatamente demitido e que o proprietário do estabelecimento tenha oferecido seus pedidos de desculpas, familiares e amigos de Young seguiram promovendo piquetes em frente ao local, atraindo mais visibilidade ao caso e trazendo para a família um "sentido de resolução do caso". 
Ora, o fato de tal notícia ser verdadeira não impediu que um segundo membro da lista viesse devidamente "restituir" ao relato seu elemento característico de lenda urbana. Escreve Beth Walker: "Look for this one to be re-re-re-re-re-re-re-circulated until the end of days. Names and stores and locations will change, but the inherent bigotry will never die." Não tendo, provavelmente, acompanhado o desenrolar dos acontecimentos, Walker acredita tratar-se de mais um exemplar de um suposto arquivo de textos contando a mesma história de anti-militarismo, ou mais abrangentemente, antiamericanismo. De fato, enquanto em Snopes o relato sobre Jason Young recebe o selo True - encaixando-se na categoria de lendas urbanas que "de fato aconteceram" -, o leitor do site é remetido a um caso supostamente ocorrido em março de 2003 em uma rede conhecida de restaurantes no sul dos Estados Unidos, este também narrado por meio de um e-mail em franca circulação na Internet. Na ocasião, cinco fuzileiros navais teriam sido expulsos de um restaurante em Hilton Head, Carolina do Sul, e, questionando o porquê de estarem recebendo tal tratamento - afinal não estavam bêbados nem haviam causado qualquer tipo de confusão - , teriam recebido a seguinte sentença: "We do not support the war, and your presence here is a disruption." Sem direito a pedido de desculpas posteriores. O e-mail é assinado por Erik Smith, alguém que se apresenta como tendo ouvido o relato diretamente da fonte e que, embora se considere prudente ao espalhar histórias que, como essa, costumam lhe chegar, insiste haver no caso motivos para levá-lo a sério e considerar a possibilidade de boicotar o estabelecimento em questão.

O argumento em que Smith se baseia para tal é o de que quem não apóia os militares não tem direito às liberdades que estes lutam para proteger, e portanto não merece gerir qualquer negócio nos Estados Unidos, nem lucrar com ele. Mais ainda: uma vez que, sem os militares, essas pessoas não teriam sua liberdade de expressão garantida, elas não deveriam ter o direito nem mesmo de expressar uma opinião naquele país. O detalhe a se destacar aí, na elaboração do argumento, é o uso repetido do pronome "you”, genérico e impessoal - “... if you do not support the members of our military, you do not deserve the freedoms they fight to protect (...) without our military you would not have freedom of speech...” - para se referir aos tais inimigos da nação, a essa altura já não somente os proprietários do restaurante, mas qualquer “ilegítimo americano” a quem possa servir a descrição. 
Com base na investigação detalhada conduzida por Snopes, e para além de todas as suas semelhanças formais e temáticas com o relato anterior, o caso, no entanto, recebe como veredicto o estatuto False. Seria apenas a formulação particular de um rumor que apareceu em outras cidades (como Duluth e Pontiac) e que era contado, com certa recorrência, como verdadeiro. Se há, portanto, uma tradição lendária, ainda que de poucos exemplares, o caso envolvendo o fuzileiro naval ilustraria mais uma vez o que os estudiosos chamam de ostensão; ou seja, casos encenados na vida real inspirados por acontecimentos supostamente fictícios. Ou seria, talvez, mais o caso de pensarmos que a crescente tendência antiamericanista por si só justificaria manifestações “espontâneas” ou seja, não necessariamente motivadas por relatos prévios - como a recusa de servir um representante de uma instituição vista com suspeita ou rejeição? Afinal, quem seriam esses antiamericanos?

É esse ponto que a intervenção de Beth Walker parece enfatizar. Conforme diz, ela pode até imaginar por que as pessoas condenam a (real?) manifestação de preconceito anti-militarista. Ela também se sentiria ultrajada se tivesse recebido um tratamento discriminatório - negando-lhe o direito a um serviço comum em um estabelecimento público - como o que foi conferido ao jovem fuzileiro. Porém, o que mais lhe retém a atenção é justamente o parágrafo do e-mail de Dowell que descreve o comportamento de these people e que reverbera em mais de um ponto o relato assinado por Smith. Walker está preocupada com a questão de quem seriam, afinal de contas, “essas pessoas” que vêm aos Estados Unidos, gozam das liberdades pelas quais se está disposto a morrer, e que deveriam voltar para o lugar de onde vieram. Quem seriam esses they insistentemente repetidos? Estaria Dowell se referindo ao funcionário e o gerente da loja de conveniência?

Para Walker, a irmã do fuzileiro não saberia distinguir uma pessoa de ascendência iraquiana (ou do Oriente Médio) de uma de ascendência indiana (ou asiática) se ambas lhe dessem uma mordida em seu "traseiro caipira hipócrita e intolerante (bigoted, self-righteous, hayseed ass)”. Ela acredita que o funcionário e o gerente da loja não representam todas as pessoas com ascendência no Oriente Médio, nem um pouco mais do que a Senhorita Dowell, com sua “xenofobia reacionária e intolerante (narrow-minded, reactionary xenophobia)”, representa todos os texanos. Aqui o insulto é uma arma contra outro insulto. Ele não deixa, no entanto, de trazer à superfície do discurso o efeito de uma consciência do caráter fluido e não-essencial da 
identidade - tanto a do "mesmo", aquele que fala "de dentro" da sociedade americana, como a do "outro", este que vem "invadir” um território, gozar de suas benesses e ainda por cima tripudiar sobre aqueles que lhe "garantem” tais direitos.

Assim como aquele they da mensagem indignada contra os mexicanos que vimos na seção anterior, e o you da mensagem de Erik Smith, esse these people impõe seriamente o questionamento sobre o quem da identidade, colocando em xeque uma homogeneidade que se quer a todo custo manter, mas que, nos desvãos do discurso, revelam sua vocação irremediavelmente polifônica. Ainda que sua referência possa, aqui e ali, ser recuperada na "superfície do texto”, pelas operações lógico-semânticas da coerência e coesão, esses contestados pronomes pessoais são o índice da explosão conflituosa de sentidos implicada pela segmentação forçada de um them (ou you) contra um us. São a manifestação, na materialidade do discurso, da naturalização de uma cesura que mal se consegue enxergar como existente, desde-sempre, no interior do próprio “mesmo”.

O que, em última instância, a intervenção indignada de Walker sobre os casos de xenofobia relatados (verdadeiros ou não!) nos permite contemplar é a dose de artificialidade que está envolvida na essencialização e polaridade das identidades - na crença, no caso aqui, de que (todos) os nativos do texanos são reacionários e intolerantes e de que (todos) os originários do Oriente Médio estão livres por aí, rechaçando aquilo que supostamente lhes garantimos como um “direito”, e prontos para nos pegar de surpresa e morder nossos traseiros.

O antiamericanismo pode ser expresso também por meio de uma forma de estereotipização aparentemente mais prosaica, muito freqüente no anedotário popular: a associação de uma dada nacionalidade à imagem de pessoas estúpidas ou, simplesmente, burras. Trata-se de uma modalidade bastante conhecida de narrativa, que no Brasil tem como alvo os portugueses (e em Portugal, os brasileiros); nos Estados Unidos, os irlandeses; na Alemanha, os turcos; e tantos outros em diferentes nações do planeta. Uma narrativa desse tipo - mas com ares de lenda urbana - surgida na lista de discussão em 27 de julho de 2005 com o título Chain Email about Stupid American, ilustra exemplarmente tal modalidade. Nesse dia, o tablóide eletrônico húngaro Pestiside.hu publica um relato segundo o qual um turista americano em férias na Hungria teria alugado um carro da marca Citröen ao chegar em Budapeste. Por não saber usar o sistema de câmbio de marchas manual, pouco usual em seu país, o turista 
americano teria fundido o motor do carro ao dirigi-lo a 80 quilômetros por hora, por mais de 200 quilômetros, sempre em primeira marcha! O relato, transmitido via e-mail por toda a Hungria, vinha acompanhado de quatro fotos do veículo após o incidente, das quais a seguinte é reproduzida na reportagem do tablóide.

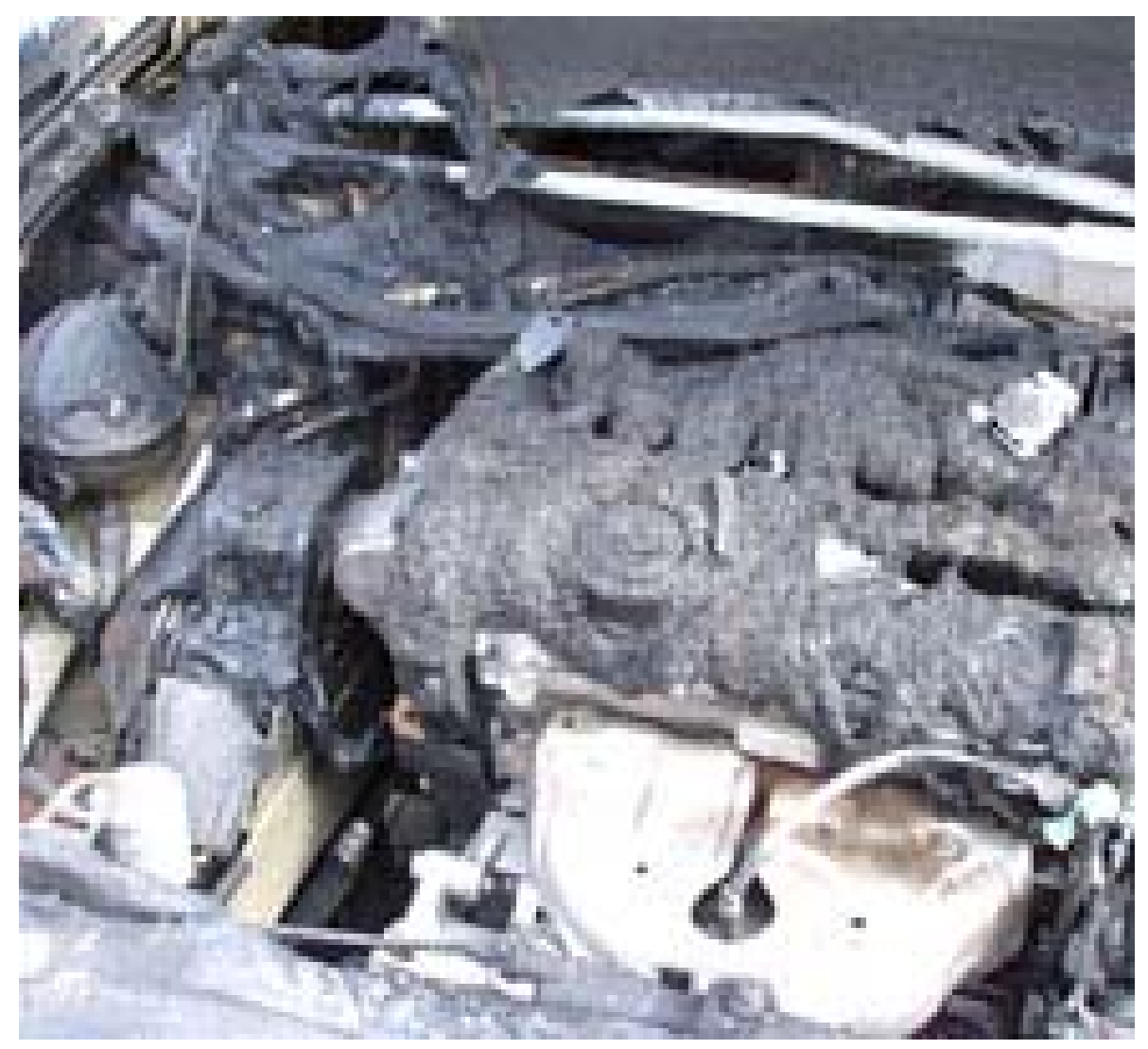

Embora não passasse de mais uma entre as incontáveis peças de folclore eletrônico, a história gerou o usual alarmismo de primeiro momento, com inúmeras pessoas entrando em contato com a agência de aluguel de veículos para se informar do ocorrido, e o dono do estabelecimento passando o dia inteiro esclarecendo os fatos e desmentindo o relato. O veículo havia, de fato, sido alugado no local, e o carro havia, sim, se incendiado. Mas ao volante estava, na verdade, um motorista húngaro que havia forjado um passaporte americano. A causa do acidente, um incêndio repentino, permanecia ainda sob investigação.

Mas o que poderia passar como uma "anedota real” com todos os elementos de uma “piada de estrangeiro burro” - já tantas vezes contada em inúmeras versões e com 
os mais variados alvos de discriminação ${ }^{57}$-, passa a ser, na lista de discussão, o pontapé inicial para um dos mais longos threads de nosso corpus, composto de uma seqüência de 67 respostas. E a primeira delas lança já a plataforma de toda a polêmica que irá se seguir. Sem maiores detalhes ou comentários, a mensagem, assinada por R. Culpin, contém tão-somente o questionamento: "Why should we be surprised that someone would make fun of Americans? Why should we be offended?’.

No dia seguinte, o leitor que se identifica pela sigla DDTLVSDTP propõe a seguinte explicação:

It's because we don't learn from our mistakes. We continue to give tens of BILLIONS of dollars every year, to nations who hate us because of our freedoms. We give tens of BILLIONS of dollars to the UN, even though one of their main targets, is to destroy the USA, so the UN can govern the world. Oh, we also let in tens of millions of ILLEGAL aliens, then give them tens of BILLIONS of dollars from The SS Trust fund. It seems like we would learn!

Tem início mais uma rodada do jogo do us vs. them, embora aqui o them/their assuma referências menos ambíguas (ainda que não totalmente determinadas): são as "nações que nos odeiam por nossas liberdades"; a ONU, que tem como um de seus objetivos “destruir os Estados Unidos, para que assim possa governar o mundo”; e, finalmente, como não seria de se estranhar, as "dezenas de milhões de imigrantes ilegais, a quem damos dezenas de bilhões de dólares do fundo de previdência social”. Nós queremos ajudar o mundo, mas nós não ainda não aprendemos que eles nos odeiam.

\footnotetext{
${ }^{57}$ Em sua análise sobre piadas, Sírio Possenti (2002: 155-166) formula a hipótese de que os estereótipos a respeito de nacionalidades, identidades culturais, etc. - sobre os quais se sustenta o gênero seriam a manifestação particular de simulacros identitários. Para o lingüista, baseando-se em Maingueneau (1984/2005), o simulacro é uma identidade atribuída a um grupo a partir de um outro lugar, isto é, por um Outro que, tipicamente, se apresenta como seu oposto. De acordo com esse raciocínio, poderíamos afirmar que o estereótipo do americano como conhecedor de tecnologia avançada é aqui subvertido, sendo-lhe conferido, como parte de "sua identidade", um atributo oposto - um simulacro - pelo qual o americano é representado como "burro", alguém que, apesar de deter o domínio técnico associado à modernidade, não é capaz de se desembaraçar minimamente diante de um "desafio cultural”. Ou, interpretando de outra maneira, o americano, justamente porque está acostumado ao conforto e absoluta praticidade das tecnologias modernas que produz e tem à mão, é incapaz de lidar com formas mais elementares ou "menos avançadas" de uso desses mesmos produtos. Por meio desse simulacro construído pela piada, mas aqui também pelo fait divers -, tratar-se-ia de articular uma espécie de "vingança simbólica".
} 
R. Culpin, contudo, não vê as coisas assim tão "branco ou preto”. Retomando o jogo de pronomes, afirma: “WE owe China about S700 Billion right now. It's thanks to them that we're enjoying low interest rates and incredible government spending." $\mathrm{O}$ primeiro “WE”, assim, em letras maiúsculas, aponta para uma outra direção possível na argumentação. Trata-se de reconhecer que, nos dias atuais, o capital flui de todos os cantos do planeta para todos os cantos do planeta. E que as nações dependem uma das outras para continuar usufruindo de suas supostas liberdades. O que de fato observamos, cada vez mais, é a incontornável globalização do capital econômico, o que torna um tanto inconsistentes reduções como as que insistem na identificação de um we magnânimo e generoso que é “salvador injustiçado, vítima dos they ingratos do mundo”. Quanto aos imigrantes ilegais, esclarece Culpin, estes ainda não ultrapassam os 10 milhões de indivíduos (aproximadamente 0.3\% da população dos Estados Unidos) e, com raras exceções, "they are caring for your babies, maintaining your yards, harvesting your produce, and trying to build a better life”. Em outras palavras, é para você que eles estão trabalhando. Se alguns deles nos odeiam, conclui, é simplesmente porque lhes negamos a oportunidade de serem livres.

DDTLVSDTP persiste em sua linha de argumentação, salientando as diferenças entre o período em que os Estados Unidos realmente se beneficiaram com a vinda de imigrantes da Irlanda e o momento atual, em que o país, contando com uma superpopulação e sofrendo de uma dívida interna exorbitante, continua a abrigar imigrantes do mundo inteiro, não só latinos. Uma das diferenças mais notáveis, para o autor, é a de que os custos são muito mais altos quando se tem, por lei, de ensinar inglês - ou providenciar serviços de interpretação de outras línguas em atendimentos médicos públicos, por exemplo - para pessoas que se recusam a aprender. Donde se pode concluir, por tais argumentos, que os irlandeses não eram tão outros assim - pelo menos não em termos de uma suposta identidade lingüística - quanto os outros latinos, ou ainda outros tantos cuja língua materna não é o inglês.

O fato de falarem inglês, no entanto, não impediu, segundo Culpin, que os irlandeses, quando de sua chegada em grande número em território americano, e por décadas seguintes, fossem vilipendiados como "preguiçosos, estúpidos e bêbados arruaceiros”. Na verdade, o inglês que falavam não era nem considerado propriamente como inglês, e os empregos que lhe restavam não podiam ser chamados de decentes. Quanto aos não-falantes de inglês, Culpin argumenta que a dificuldade que os 
imigrantes - especialmente no caso de pessoas mais velhas - apresentam na aquisição da língua não deveria ser confundida com uma recusa a aprendê-la.

Neste exato ponto, a argumentação traçada de ambas as partes do debate me remete a uma breve reflexão, inspirada por Jean Baudrillard (1990/1996), sobre o estatuto teórico da relação entre diferença e alteridade. Defende o autor que quando o outro - no caso aqui o imigrante ilegal, mas também o legal; o latino, mas também o irlandês de outros tempos - começa a existir como uma presença ameaçadoramente próxima, ele se torna algo distinto do mero outro diferencial; quer dizer, ele deixa de ser aquele outro do qual se aliena, e a partir do qual se delimitam barreiras, pela operação mesma da diferenciação, que é por definição excludente e que acaba por aniquilar a alteridade. Quando o outro deixa de ser simplesmente o estranho que tem seu estatuto de estrangeiro “devidamente” reconhecido - isto é, o estatuto de quem deve permanecer lá, “em seu lugar” - e ousa ultrapassar as fronteiras que separam eles de nós, é aí então que se “desperta a veleidade de mantê-lo à distância” (Baudrillard 1990/1996: 136). A alteridade radical, a que deixa o outro ser outro e que não se deixa reduzir a um mero jogo de trocas/diferenças tornadas possíveis por uma simbolização de tipo dual estruturalmente condicionada - o outro do mesmo, o mesmo do outro -, essa é muito difícil de suportar. Assim é que, para usar ainda os termos de Baudrillard, toda a forma de alteridade radical acaba por inscrever-se em (assimilar-se a) um discurso da diferença, "que implica simultaneamente a inclusão e a exclusão, o reconhecimento e a discriminação”. Pois onde não é possível a troca regulada das diferenças, aí vem se instaurar "o epicentro de um terror" (op. cit.: 135).

Mas é também neste ponto do thread que Culpin chama de volta à lembrança o motivo inicial a partir do qual toda a discussão se originou. O objetivo era entender por que deveríamos nos surpreender, ou mesmo nos preocupar, com o fato de que algumas pessoas julgam os americanos estúpidos. Para Culpin, toda a argumentação do Senhor DDTLVSDPT ilustra, como que numa prova textual, “a profundidade dos nossos preconceitos (the depth and blind viciousness of our prejudices)". Se nós podemos ser tão virulentamente preconceituosos, não deveríamos nos surpreender com o fato de que outros também o podem ser, nem com o fato de que possamos ser vistos como inferiores, estúpidos ou perigosos - por húngaros, mas também por terroristas islâmicos agindo em nome de Deus, conforme lembra mais adiante o autor. 
Os itálicos em nós e nossos no parágrafo anterior são estrategicamente meus (não de Culpin), e eles servem para expressar um simples pensamento: se o Senhor R. Culpin, ao incluir-se como americano, acaba, por um efeito do real da língua (o uso do pronome evasivamente inclusivo), reconhecendo-se como pertencente a uma identidade nacional projetada, sempre-já cindida e heterogênea - que identifica o outro (o oponente no debate, ou o suposto inimigo a ser combatido) como elemento constituinte do si mesmo -, então também eu gostaria de poder provocar tal efeito com meu texto, declarando-me, assim, “consciente” dos equívocos que a visão estereotipada do outro pode me levar a incorrer. Considero-me, de minha parte, também inserido em uma nação (comunidade interpretativa, formação discursiva) que ora se vê como o Mesmo que assimila o Outro à sua lógica, ora se vê, literalmente, como um outro, à margem, excluído. Quero, contudo, estar o mais possível atento a essa cisão, enxergar nela a alteridade irredutível, evitando assim cair nas armadilhas mais fáceis de um mero jogo de diferenciações ${ }^{58}$.

\section{Children of the World}

Nossa última conexão nos leva rumo a narrativas que envolvem crianças sendo seqüestradas e/ou adotadas ao redor do mundo. Por que há tantas histórias de tráfico de crianças do chamado Terceiro Mundo para o chamado Primeiro Mundo? O que essas histórias têm a nos dizer a respeito da discussão sobre identidade e alteridade que vimos traçando até aqui? Nosso corpus de pesquisa apresenta uma série de relatos que, aparentemente distantes entre si temática e geograficamente, sugerem algumas aproximações possíveis.

Comecemos pela identificação de um motivo bastante recorrente: casais americanos ou europeus viajam a países da América Latina, África e Ásia em busca de crianças para adoção com a finalidade de traficar e comercializar seus órgãos, ou usá-las em operações de pornografia infantil. Ainda em junho de 2004, eu havia selecionado

\footnotetext{
${ }^{58} \mathrm{O}$ thread avança ainda por umas tantas mensagens. Porém, o teor da discussão tende a se concentrar em duas frentes: (1) o tráfico ilegal de drogas através das fronteiras entre México e Estados Unidos e (2) o questionamento do pressuposto, sugerido por DDTLVSDPT, de que Deus ouve a todos os clamores, que só ele tem a salvação eterna para os conflitos que afligem seus súditos na Terra, e que ele se dirige diretamente a certas pessoas dizendo qual a coisa certa a fazer. Tal desvio do tópico inicial do thread recomenda, no que concerne os propósitos do capítulo, a passagem para a próxima seção de análise.
} 
uma mensagem que reportava o caso de um casal do Alabama que fora detido por seqüestrar uma garota mexicana de sete anos de idade enquanto brincava no jardim de frente de sua casa em um subúrbio de Monterrey, importante cidade do norte do México localizada a duas horas da fronteira com o Texas. A reportagem, publicada pela agência de notícias Associated Press e de autoria de Olga R. Rodriguez, dá destaque a um rumor que amedronta os mexicanos. Já na manchete, lê-se: “Alabama couple arrested for kinapping Mexican child, fueling fears that foreigners are stealing children"; e na primeira sentença do texto, “constata-se”: "Many Mexicans have long believed Americans are sneaking into Mexico to steal their children.”

Desde logo, chama a atenção um deslocamento referencial pelo qual identificam-se os seqüestradores genericamente como estrangeiros (foreigners) em um primeiro momento, e como americanos em um momento imediatamente posterior. Também torna-se claro, logo na primeira frase, que se trata de their children, as crianças deles, mexicanos, e não simplesmente crianças, o children da manchete. O relato da detenção do casal (ambos com 34 anos de idade) viria, portanto, confirmar os piores temores deles, mexicanos - “it confirmed their worst fears”. A reportagem segue mencionando os rumores que surgiram em torno do caso. O repórter de uma rede de televisão local afirmara que o casal queria seqüestrar a menina por seus órgãos, e que os suspeitos haviam sido encontrados com um álbum repleto de fotos de crianças mexicanas - o que levou moradores a congestionar as linhas de telefone da emissora relatando ter visto o casal tirando fotos por toda a cidade. Na seqüência da investigação, outros canais de mídia veicularam a hipótese de o casal fazer parte de uma rede internacional de pornografia infantil. A reportagem remete, ainda, a casos passados semelhantes e de grande repercussão, como os que teriam ocorrido na Guatemala no início dos anos 1990. Na época, o Departamento de Estado norte-americano havia lançado comunicados de alerta a viajantes sobre o suposta ação de ladrões de crianças no país da América Central.

O evoluir da investigação comprovaria que o casal havia de fato seqüestrado a garota, uma vez constatadas as dificuldades de adoção por vias legais - dificuldades essas que se julgava bem menores. Segundo informações que o casal teria obtido de colegas norte-americanos, muitas famílias pobres mexicanas estariam dispostas a dar suas crianças. Atraindo a menina para dentro de sua van - elemento este recorrente, aliás, no lendário urbano “clássico” - oferecendo-lhe biscoitos inspirados no 
personagem de desenho animado Bob Esponja, o casal havia sido flagrado por uma vizinha, que os perseguira em um táxi e reportara o caso à polícia. O julgamento, ocorrido exatamente um ano depois - de acordo com mensagem coletada em junho de 2005 reproduzindo outro artigo da Associated Press -, resultou na condenação do casal a 27 anos de prisão, tendo sido constatado ainda que já haviam recebido recomendação para aconselhamento psiquiátrico em função dos distúrbios mentais manifestados em diversos chamados policiais desde seu casamento em 2004. Nada que contribuísse, no final das contas, para dissipar o "pior dos medos mexicanos”: o de perder suas crianças para inimigos tão próximos geograficamente, mas tão vagamente identificados como o malvado outro (americano) que atravessa a fronteira do Primeiro para o Terceiro Mundo com bem outros sonhos em mente...

O medo de ter uma criança vítima de redes internacionais de abuso não se limita, como já poderíamos supor, à conexão mexicana. Por ocasião da tsunami ocorrida no sudeste asiático no final daquele mesmo ano, eu lia numa mensagem remetendo a artigo do jornal britânico The Guardian (4 de janeiro de 2005) a história de um garoto sueco de 12 anos que, visitando a Tailândia com a mãe e os irmãos, desapareceu em meio ao caos da tragédia. Convencido de que o garoto havia sobrevivido à tsunami (assim como seu irmão mais velho e sua irmã mais nova), mas temendo que ele tivesse sido pego por “alguém envolvido com a indústria do sexo infantil”, o pai do garoto pedia um alerta da Interpol para o caso. Médicos no local testemunharam terem visto o menino duas vezes no hospital, em ambas ocasiões acompanhado de um senhor de meia-idade de aparência européia. O que levou seu avô paterno, um cidadão norte-americano, ex-fuzileiro e paramédico a prontamente concluir: "This man could be someone who is doing the wrong thing because he is retarded or something, but I don't buy that, (...) What else is there? It is either trafficking or trade in organs." Ou uma coisa ou outra. Sem muita chance para o acaso. O tal cidadão, ainda que de aparência provavelmente tão européia quanto à de uma família sueca em meio a tantos asiáticos, se configurava, desde já mediante a ausência de qualquer outra evidência senão a que eu chamaria de "evidência da narrativa lendária de todos os dias” - como o autêntico vilão da história. Um ele que na aparência poderia ser um de nós, mas que se revela um fantasma anônimo e perfeitamente real, qualquer que seja seu lugar de origem.

Eis que um site, www.kristianwalker.net, é construído (e regularmente atualizado) em memória do menino e de sua mãe, tidos desde então como mortos. Nele, 
leremos a notícia divulgada pela Associated Press de que aquele homem de aparência européia era um alemão de Munique, residindo com a mulher na Tailândia, que havia se voluntariado no resgate de vítimas da tragédia. Entre essas vítimas estava um outro garoto sueco de cabelos loiros e longos, apenas levemente parecido com Kristian, e que logo se reencontraria com sua mãe. O esclarecimento, como era de se esperar, levou o avô de Kristian, a admitir publicamente o mal-entendido. No entanto, a essa altura, repercutiam intensamente os alertas quanto aos riscos que crianças perdidas estariam correndo no rastro da tragédia - alertas já não somente na forma de rumores, mas notadamente por meio de comunicados oficiais de organizações internacionais (governamentais e não), entre elas a UNICEF e a Save the Children. A "mensagem que fica” é a de que, aparentemente, as crianças do mundo não estão imunes a nenhuma sorte de tempestades: nem as oriundas da ação implacável da natureza, nem as resultantes da própria miséria humana.

Não falta, é claro, quem se disponha a "salvar" as crianças miseráveis do mundo. Casos de adoção de meninos e meninas africanas por celebridades, por exemplo, tornaram-se já um elemento recorrente das narrativas associadas ao Continente Negro. A despeito das barreiras culturais e legais - e também, como vimos, dos mitos que envolvem brancos (americanos) agindo em gangues internacionais de tráfico de crianças -, são freqüentes os casos bem sucedidos de adoção além-fronteiras. Mas se o objetivo aqui é "salvar" as crianças, redimindo-as de sua condição muitas vezes sub-humana, há também os que busquem "salvar a si próprios" por intermédio de um poder supostamente curativo que, em determinadas lendas, é associado às crianças.

Uma dessas lendas envolve crianças virgens de origem africana. $\mathrm{O}$ seguinte texto, uma espécie de petição-corrente coletada na Internet em 2002 e publicada no site Snopes.com, evoca a lenda em uma de suas versões:

There is a myth in South Africa that having sex with a virgin will cure AIDS. The younger the virgin, the more potent the cure. This has led to an epidemic of rapes by infected males, with the correspondent infection of innocent kids. Many have died in these cruel rapes. Recently in Cape Town, a nine month old baby was raped by 6 men. The child abuse situation is now reaching catastrophic proportions and if we don't do something, then who will?

Kindly add your name to the bottom of the list and please forward this on to as many people as you know and after the 120th name on the petition, mail to childprotectpca@saps.org.za. Please don't be complacent, do something about the kids 
of South Africa! You can make a difference! That poor child is fighting for her life. This is just but one of the million cases of child abuse, so please pledge your support and help keep CPU (CHILD PROTECTION UNIT) open. This is a very important petition. SAPS are trying to close down the CHILD PROTECTION UNIT. It is an essential part of our justice system for children. Please, give your support to this petition and ensure that it goes to as many people as possible. Please do not just leave it! Cut and paste so this can stay tidy - ALL IT TAKES TO HELP ARE A FEW CLICKS!!!

After every 120 signatures, please email to childprotectpca@saps.org.za

De acordo com a investigação conduzida pelos criadores do site, a África do Sul é, sim, um dos países com maiores estatísticas mundiais de estupro - de adultos, crianças e até bebês. Em 1998, segundo dados da Interpol, o índice oficial era de 104 casos para cada 100 mil pessoas (comparados a 34 em cada 100 mil nos Estados Unidos). O caso da garota de nove meses citado na petição teria de fato ocorrido, embora a polícia tivesse chegado à conclusão de que o estupro não havia sido cometido por uma gangue de seis homens, conforme de início se acreditara, mas sim pelo exnamorado da mãe do bebê (ela própria, uma adolescente de 17 anos, à época). O crime, ocorrido em outubro de 2001, gerou grande repercussão, chamando a atenção de forma mais incisiva para o problema social na África do Sul.

Um estudo conduzido em uma região do norte do país e apresentado na Conferência sobre AIDS em junho de 2002 em Barcelona buscou investigar o alcance naquela comunidade de três crenças, segundo as quais fazer sexo com parceiro/a virgem pode: (a) curar a AIDS, (b) prevenir o contágio com a doença e (c) representar um ato de vingança por alguém que, tendo sido infectado, não deseja morrer sozinho. Os resultados mostraram que, enquanto a maior parte dos respondentes não acreditava na teoria da cura pelo contato sexual - embora afirmassem ter ouvido falar do mito através da mídia e não em conversas entre a comunidade -, a idéia de se espalhar a doença como um ato de vingança parecia ter, para esses respondentes, um impacto considerável na proliferação crescente da doença. Porém, o resultado mais controverso do estudo (ainda de acordo com a análise do site) foi o de que aproximadamente $20 \%$ dos respondentes acreditavam que fazer sexo com uma criança menor de 10 anos não constituía estupro, e sim um simples ato sexual.

De fato, pode-se concordar com a conclusão de Latasha Treger, uma das pesquisadoras, de que o estupro infantil na África do Sul é o resultado de "uma situação complexa causada pela dinâmica social de hierarquia masculina e violência contra 
mulheres e crianças” e de que, apesar de existir, sim, no país, a teoria da cura da AIDS pelo contato sexual, casos de estupros motivados diretamente por essa crença permanecem, a julgar pelas evidências predominantes, bastante infreqüentes. Entretanto, a questão toda parece apenas reforçar um argumento que venho defendendo ao longo das várias análises empreendidas neste trabalho: o de que os mitos custam a morrer e que sua permanência no fio de uma memória discursiva que "insiste” em se materializar em textos como a petição eletrônica (ou em relatos que ora e outra ressurgem na mídia) ainda pode ser detectada, e com uma certa força, justamente quando a ciência nos oferece, de sua parte, cada vez mais avanços (atestados e incontestáveis) na direção de uma cura para os mais terríveis males.

Assim é que quando lemos em 8 de fevereiro de 2005 a notícia de que dez estupros foram reportados à polícia no fim de semana anterior na região de Zululand, norte da África do Sul, nos deparamos com as seguintes palavras do capitão Musa Khaba, porta-voz da polícia local: "the myth still exists that having sex with a juvenile cures Aids (...) people should be aware by now that there is no cure for Aids”. Para os que ainda não sabem ou não acreditam, seja por quais forem os motivos, é preciso repetir tais enunciados - como se eles ainda fossem solicitados, como se eles se fizessem necessários diante de uma situação social cujos efeitos materiais estão longe de se extinguir.

Somente que, dessa vez, emerge também um enunciado “inesperado”, revestido por uma crença “nova” - “A new myth””, conforme denomina Brian Chapman, o membro da lista que enviou a mensagem - que se vem juntar àquela crença já conhecida. Ainda de acordo com o capitão da polícia sul-africano, “A new myth had now emerged that [having sex with a juvenile] also brings wealth and 'makes one prosper in business"”. Eu hesitaria, contudo, em dizer que tal novo mito seja realmente “novo”, tendo em mente que a própria crença de que o contato sexual com virgens cura doenças sexualmente transmissíveis data de (como vim a descobrir) pelo menos a Era Vitoriana na Inglaterra ${ }^{59}$. Uma investigação mais aprofundada sobre as origens de

\footnotetext{
${ }^{59}$ Havia na época a crença de que o contato com garotas que nunca haviam tido relações sexuais poderia conter o aumento alarmante de casos de doenças venéreas. Por elas estarem supostamente "limpas", não ofereceriam risco. Mas, de alguma maneira, a crença teria dado lugar à interpretação de que sexo com uma virgem faria desaparecer uma doença já preexistente. Assim, o papel da jovem seria o de curar, como numa espécie de propriedade mágica, e não simplesmente prevenir as doenças sexualmente transmissíveis. O poder curativo das virgens, aliás, é relatado em tradições bem mais antigas, algumas das quais propunham que o toque das mãos de uma delas sobre a parte do corpo afetada por algum mal provocaria, milagrosamente, a eliminação desse mal (Snopes.com 2002; Whatley \& Henken 2000: 80-1).
} 
superstições associadas à prosperidade material e financeira provavelmente me traria resultados esclarecedores. O que não posso deixar de destacar, no entanto, é o poder que a lenda tem de se infiltrar nos discursos de modo persistente, com formas mesmas, repetidas, ou formas outras, “novas”. Não posso deixar de levar em consideração o efeito que a lenda tem de despertar fantasmas, reavivar a memória de um saber obscurecido - e obscurecedor - que rema contra a corrente de qualquer possível campanha internacional de prevenção de uma doença cujas significiações, como já observamos em análise no capítulo anterior, parecem ir mais e sempre além do que uma avaliação clínica possa sugerir.

As últimas duas mensagens que compõem nosso corpus de pesquisa - enviadas à lista em 17 de dezembro de 2006 - são também, coincidentemente, os textos com que se encerra esta jornada. São sobre bebês. E, de alguma maneira, apontam para um futuro incerto. Na primeira delas, Brian Chapman envia o link para um longo artigo publicado dois dias antes no site britânico www.thisislondon.co.uk com o assustador título "The babies who are murdered to order” (“Os bebês que são assassinados por encomenda”). Reproduzo os primeiros parágrafos:

The plastic bag looks as if it contains meat. But then a right leg is taken from it and placed surgically on the morgue table, followed by the left one. Then the torso. The head follows, a gaping cavity where the brain used to be.

But it is only when the gloved hand of the pathologist examines the tiny fingers of a baby aged about 30 weeks that the full horror of what I am witnessing sinks in.

This shocking scene was captured on video at post-mortem examinations carried out on behalf of Ukranian mothers who claim their babies were stolen from them at birth.

The film was shown to me by an incredibly brave charity worker called Tatyana Zhakarova, who represents up to 300 families who believe their healthy babies were deliberately targeted at a maternity hospital in the Ukraine's most easterly city of Kharkiv.

The babies, believes Tatyana, were taken at birth to have their organs and stem cells harvested as part of a sickening but highly lucrative international trade.

Certainly, the Ukraine has become the main supplier of the global stem cell trade.

Officially, the cells are taken from aborted foetuses with the mothers' consent, but according to Tatyana, there could also be hundreds of babies stolen to order, to feed demand for stem cells from around the world. 
Matthew Hill, o jornalista que assina o artigo, começa na seqüência a relatar sua alentada investigação para a Rádio BBC 4 de uma suposta operação internacional envolvendo alegações de conspiração, assassinato e até mesmo um tratamento de beleza revoltante. Ele teria ouvido falar pela primeira vez dos rumores em conversa com o doutor Stephen Minger, da Kings College de Londres, um dos destacados nomes na pesquisa com células-tronco no país. Convidado para com encontro com médicos de uma clínica em Barbados que conduz experimentos controversos com células-tronco para o tratamento de doenças degenerativas - células essas alegadamente obtidas de bebês abortados entre sete e dez semanas de vida -, Minger teria expressado apreensão em relação aos métodos pouco transparentes de trabalho na clínica, bem como o fato de a clínica conduzir tratamentos paralelos contra o envelhecimento usando tais células. Detalhe importante: células importadas da Ucrânia e obtidas com a aprovação das mães. Haveria aí alguma ligação com as quase 300 famílias de Kharkiv citadas no início da reportagem?

O próximo passo da investigação levaria Hill a visitar a clínica em Barbados e convencer, com algum esforço, o doutor Shami Ramesh, um dos médicos-chefes, a conversar com ele no hotel. Seguro de que o tratamento funciona, Ramesh nega conhecer rumores de que bebês seriam sacrificados para a coleta de tecido e órgãos internos sem qualquer consentimento dos pais, expressando sua confiança no Instituto de Criologia de Kharkiv, que lhe fornece a matéria-prima. Mas admite: "Maybe in the future we will go and check it out."

O jornalista decide, então, fazer justamente isso. Uma vez em Kharkiv, tenta várias vezes entrevistar o doutor Valentin Greshenko, chefe do instituto. Sem sucesso. Em seguida, concentra seus esforços no Hospital-Maternidade Número 6, onde entrevista Svetlana Plusikova, uma jovem de 26 anos que, em 2002, após uma gravidez relativamente tranqüila, teria dado à luz uma menina natimorta. Pelo menos é o que, muito suspeitamente, lhe informaram os médicos, negando-lhe o direito de ver a criança. Em uma outra conversa, Hill conhece a história de Olena Stulnev , que viu sua filha nascer saudável, apenas para, no dia seguinte, ser comunicada de sua morte, para a qual foram apresentadas três diferentes versões: a criança sofrera de falta de ar, seus pulmões não abriram e seu coração falhara. Inconformados, Olena e o marido Dimitry insistiram numa explicação correta que, a cada vez, se tornava mais difícil de obter. 
Assim, procuraram Tatyana Zhakarova para representá-los, numa causa que unia diversas outras famílias cujas histórias eram bastante semelhantes.

Após alguma pressão, autoridades locais concordaram com a filmagem da exumação e exame dos corpos de aproximadamente trinta bebês. Juntamente com as imagens chocantes de corpos desmembrados, o jornalista iria se deparar ainda com uma sólida parede de silêncio, em que as acusações eram todas peremptoriamente negadas como ficou evidente no caso da conversa que o jornalista teve com Larysa Nazarenko, diretora do hospital-maternidade, que afirmou: "No work in this hospital is connected with the use of cells. This is the wrong address. I deny everything." E ainda: "The children are not lost... They are not stolen - that's just somebody else's illusion.” A repercussão dessas histórias, ilusórias ou não, chegaria às portas do Conselho Europeu, que atualmente conduz uma investigação própria do caso, retomada após uma primeira iniciativa (ainda em 2004) frustrada por falta de evidências concretas.

A segunda mensagem do thread, que, na verdade, é a única que comenta diretamente o assunto, vem de Joe Yuska. E ela permanece no lado da reticência, abastecida por mais e mais informações. Após pesquisar na enciclopédia virtual Wikipedia, Yuska apresenta o argumento de que células-tronco embriônicas são tipicamente obtidas de blastocistos, que são embriões em estágio muito inicial de evolução, bem anterior ao de fetos da idade referida na reportagem. Já as células-tronco adultas podem ser extraídas sem maior prejuízo ao doador. E quanto ao fato de os bebês em questão aparecerem nos vídeos assustadoramente desmembrados, ele pensa tratar-se mais provavelmente da ação de "malucos" (whackajobs) do que de agentes de uma rede de comércio internacional, como declarara acreditar a representante das famílias de Kharkiv $^{60}$.

Então, o que temos aqui se não a mais nova fronteira no ciclo aparentemente ilimitado de narrativas em torno da vitimação de crianças? Quer sejam destinadas a adoção, quer ao roubo de seus órgãos internos, quer agora para pesquisa e exploração de células-tronco, as crianças do mundo - neste nosso último caso, fetos: primeira fronteira, fronteira última? - as crianças são mais uma vez os personagens centrais de

\footnotetext{
${ }^{60}$ Um segundo artigo, publicado no site do Sunday Telegraph ("Stem cell baby deaths probe 'too close to the truth', claims investigator", 17 de dezembro de 2006), e incluído ainda na mensagem de Brian Chapman, cita uma parlamentar suíça, membro do assembléia do Conselho Europeu, que, apesar de acreditar nas histórias das mães e de haver informações confiáveis para substanciar seus relatos, está mais convencida da hipótese de os bebês terem sido roubados para fins de adoção em países ocidentais.
} 
uma grande rede narrativa onde se entrelaçam questões legais, médicas, científicas, religiosas e, obviamente, emocionais.

O debate cada vez mais acirrado na sociedade atual sobre quando exatamente começa a vida está na base das decisões quanto ao futuro da pesquisa com célulastronco. As diversas posições tendem a se condensar numa polarização que entrincheira, de um lado, os que defendem a vida em “todas as suas fases”, e, de outro, os que clamam por um limite legal, pragmaticamente estabelecido, a partir do qual torna-se aceitável manipular a matéria-prima humana ${ }^{61}$. Em meio a esse debate, as crianças são, de um lado, representadas como sujeitos plenos, assegurados de seu direito à vida; de outro, como outros objetificados, definíveis por critérios de posse, utilidade ou franca exploração. Tão iguais a nós mesmos, tão estranhas a nós mesmos.

E o que as lendas urbanas têm a ver com isso? Ora, parece-me que elas - tanto essas sobre células-tronco quanto as analisadas mais anteriormente nesta seção - estão aí para se tentar preencher uma lacuna de indeterminação, um espaço nebuloso do discurso onde valores tão “concretos” e, ao mesmo tempo tão "sagrados” quanto o dom divino da vida e o direito a ela são mobilizados, em ambos os flancos do debate. Lá, onde essa falta, essa indeterminação provoca uma ruptura nas crenças inabaláveis da fé religiosa e da objetividade científica, lá infiltram-se as nossas velhas-novas narrativas do cotidiano. Lá aparecem elas, nos relatos jornalístico-investigativos, mas também nos e-mails e textos apócrifos da Internet "cheirando a lenda urbana”; nas declarações oficiais - supostamente sustentadas por “evidências e dados concretos” -, mas também nas que são “arrancadas” a contra-gosto - como o discurso do médico da clínica em Barbados, que admite a dúvida contra o melhor de seus interesses, e o da chefe do hospital-maternidade de Kharkiv, sintomaticamente cheio de negativas -, bem como nas que são conduzidas ao abrigo de um semi-anonimato - as colhidas “em surdina” entre os pais das crianças para a reportagem - ou simplesmente nas que são condenadas, por silenciamento, a um permanente anonimato.

\footnotetext{
${ }^{61}$ A médica Alice Teixeira Ferreira, da Universidade Federal de São Paulo, coloca a questão nos seguintes termos: "Não dá para saber com certeza se um embrião [congelado] é inviável ou não. Se é viável, aquilo é uma vida e tem de ser protegida". E acrescenta: "Todo livro de embriologia de mamíferos diz que a vida se inicia na concepção. Sabemos disso desde 1827”. Já a geneticista Lygia da Veiga Pereira, da Universidade de São Paulo, pondera: "Claro que o embrião é uma forma de vida. O que temos de definir é em que estágios da vida humana nossa sociedade vai permitir interferências” (citações de “A batalha das células-tronco", artigo da Revista Época, 23 de abril de 2007 - ver Segatto (2007)).
} 
O fosso intransponível que aparentemente existe entre um discurso Mesmo e um discurso Outro revela-se nada mais do que um espaço compartilhado, onde as mesmas vozes ecoam de ambos os lados - um espaço onde os argumentos pró-vida e os argumentos pró-ciência são irremediavelmente assombrados pelo espectro um do outro. Justamente onde é impossível compartimentalizar o debate, simplesmente "deixar de lado” as questões subjetivo-emocionais e se ater aos fatos, é lá onde a cisão se evidencia. É lá que o discurso do Outro revela ser constitutivo do Um - não como mera estratégia retórica, mas antes como condição necessária de existência. Afinal de contas, se o discurso do direito à vida - e em última análise a um futuro longevo e imune a doenças para toda a humanidade, do bebê que finalmente vê a luz do dia ao idoso que não quer morrer tão já - fosse transparente; isto é, se esse discurso estivesse definitivamente assentado, objetivamente formulado "em sua própria evidência”, não haveria a necessidade de tantas narrativas, “mais ou menos plausíveis”, "ficcionais ou não”, virem lhe preencher a falta. 


\section{CONCLUSÃO}

"Para alguns, o já-dito é fechamento do mundo. Porque estabelece, delimita, imobiliza. No entanto, também se pode pensar que aquilo que se diz, uma vez dito, vira coisa no mundo: ganha espessura, faz história. E a história traz em si a ambigüidade do que muda e do que permanece. (...) [M] antenho a tensão como motivo da minha reflexão. Embora, na ilusão da onipotência, não deixe de tentar a especificidade, o único, o definido."

- Eni Orlandi, A Linguagem e seu Funcionamento, 1983

Um lugar em que tensões dialéticas se materializam sob a forma de narrativas inusitadas do cotidiano: entre o sistema (como positividade, conjunto de regularidades relativamente estáveis) e seus deslocamentos (como movimento, condição de existência do próprio sistema). Entre a estrutura e o acontecimento. Um olhar em retrospectiva para nossa visita ao universo das lendas urbanas, para o percurso empreendido ao longo de todo este trabalho, nos deixa esse traço permanente, essa marca que se retém e que deve agora, à guisa de conclusão, ser recuperada. Proponho, portanto, nestas páginas finais, lançar um olhar panorâmico sobre o percurso, ao modo de quem revê um filme em fast forward, buscando não uma imagem ou outra que se tenha impresso na memória, mas um fluxo, um contínuo construído por algum fio condutor - marca de uma positividade/regularidade ainda que tenuamente tecida no "acontecimento" que foi a própria escrita deste trabalho. Busquemos então, re-iluminar o itinerário, trazer à superfície esse fio condutor traçando sua composição desde as páginas (cenas) iniciais, passando por seu desenvolvimento ao longo dos capítulos, os de teoria e os de análise (seqüências centrais), e desembocando aqui no seu epílogo (seqüência final).

Como pudemos observar logo na Introdução, a um pensamento, caudatário das teses de Benjamin, segundo o qual a narrativa perde cada vez mais espaço nas sociedades ocidentais contemporâneas - pelo menos aquele tipo de narrativa que Lyotard chamava de metanarrativa -, opõem-se a visão, defendida, entre outros, por Ricoeur e Certeau, de que a experiência do cotidiano não prescinde de modo algum da narrativa; ao contrário, elabora-se e ganha sentido (também) a partir dela. Eis aí uma primeira tensão.

O que talvez tenha mudado desde a época de Benjamin seja uma consideração maior ao aspecto impregnante da narrativa no próprio tecido do que chamamos 
cotidiano - a ponto de tomarmos relatos tais quais os rumores e as lendas urbanas como modos naturais de lidar com a experiência fragmentada da vida nas sociedades contemporâneas. O enfoque passa a incidir, portanto, sobre o tecido interdiscursivo que compõe a experiência humana, materializada na linguagem em suas diversas formas (mais ou menos estáveis) de manifestação.

Se as narrativas a que Benjamin dedicava sua atenção podiam se apresentar como obras fechadas, produtos acabados atestando o "lado épico da verdade”, os relatos de que tratei neste trabalho se configuram, em grande parte, como seus opostos. Como pude argumentar na Introdução e no Capítulo 1, não estamos diante de textos fechados, nem mesmo versões estabelecidas e definitivas desses textos. As lendas urbanas se infiltram em práticas discursivas de diferentes naturezas: em rodas de conversas de bar, chats, blogs, crônicas e relatos pessoais, para citar somente alguns. Mas elas também podem se sustentar como práticas discursivas por si sós quando passam a ser objeto de discussão, comentários, refutações, esclarecimentos, “desbancamentos” e análises além obviamente de sua produção e distribuição como lendas. Assim se dá na comunidade da Internet dedicada ao tema, fonte da maior parte do corpus constituído para investigação no trabalho. Lá, as lendas urbanas são a matéria-prima de todo o discurso, sua razão de existência e seu motor propulsor.

Na Introdução, aludi ainda ao fato de que o corpus se constitui como espaço de experimentação e interpretação, espaço contraditório onde não se irá buscar as lendas, textos (documentos) prontos a ilustrar as temáticas e questões estabelecidas como objeto da análise. Antes, o corpus irá atestar o modo como os discursos se firmam, se “positivizam” como regularidades (monumentos), mas também se confundem inescapavelmente com outros discursos, no interior de uma prática. O corpus é, de acordo com essa reflexão, uma espécie de palco para a encenação dos discursos. Isto é, aquilo que achamos que sabemos sobre um tal gênero denominado "lenda urbana” será testado, confirmado, contestado, enfim, construído na própria da prática discursiva prática múltipla que se estende até este lado de cá, na escrita mesma deste trabalho, que chega agora (provisoriamente) ao fim.

O que nos remete à discussão conduzida na primeira metade do Capítulo 1 em torno das tentativas de definição do gênero lenda urbana. Vimos como os teóricos de folclore enfatizam elementos distintos na caracterização de um gênero que parece nascer, desde logo, como um “amálgama”, uma forma atomizada, sobressaindo-se ora a 
questão da crença, ora os apelos de uma comunidade, ora os anseios e medos aí simbolizados. Em comum, a percepção de que a lenda só se “completa” enquanto gênero por meio de uma orientação externa, isto é, por meio da consideração das condições de produção/recepção de seus textos, as quais incluem: as circunstâncias imediatas da enunciação, bem como (nos termos de Bakhtin) a atitude responsiva efetivamente enunciada ou virtualmente projetada - que os textos suscitam entre os interlocutores envolvidos, além, é claro, da natureza particularmente heterogênea do gênero, o que se atesta pelo “diálogo” constante entre a lenda e gêneros afins, como o rumor, o fait divers e a notícia de jornal cotidiana.

Dentro dessa perspectiva, creio que algumas das análises empreendidas na segunda parte do trabalho evidenciam o caráter eminentemente situado das lendas urbanas (e, de resto, de qualquer outro gênero, em maior ou menor grau), isto é, o fato de estas se constituírem simultaneamente como práticas reguladoras, tendentes à fixação e estabilização (por vezes estereotipada) dos sentidos - por exemplo, nas lendas envolvendo alimentação, afloram enunciados inscritos numa memória discursiva tais como: "Eu não tenho coragem de comer comida feita na rua / com peixe cru / que tem carne de porco / servida por chinês / de restaurante nordestino, etc.” ou “Comida, só a feita em casa, pela mamãe/minha mulher/dona-de-casa" - e como espaço de deslocamentos, operados em virtude da própria inserção sócio-histórica-ideológica dos sujeitos que conduzem essas práticas - para ficarmos no mesmo exemplo da comida, toda uma economia ou regime discursivo em torno da saúde, do culto ao corpo, da qualidade de vida parece se abastecer dos medos, ansiedades e apreensões quanto ao comer bem e corretamente que são simbolizados nas/por meio das narrativas cotidianas, de tal modo a nos permitir sustentar a tese de que a lenda (mas não só ela, obviamente) alimenta a realidade, contribuindo para efeitos visíveis nos modos de agir das sociedades contemporâneas. Entre esses possíveis deslocamentos, eu citaria ainda o incremento da longevidade e a percepção maior de juventude aliada à saúde corporal observados nessas sociedades (ainda que, em contrapartida, o aumento dos chamados distúrbios alimentares, por exemplo, seja igualmente considerável).

No Capítulo 1, recorri também aos mecanismos e procedimentos apontados por Foucault em A Ordem do Discurso (1971/1996) - tais como o tabu do objeto, o ritual da circunstância, o comentário e o autor - para discutir o caráter auto-regulador das práticas discursivas tal como se desenrolam na lista de discussão estudada. Em alguns 
momentos da análise, fica claro como alguns desses mecanismos e procedimentos intervêm diretamente em tais práticas, tornando-se em certos casos o motor principal das trocas de mensagens. No caso da análise sobre o “americano estúpido” no Capítulo 6 (seção 2), por exemplo, vimos como uma indagação aparentemente simples - "Why should we be surprised that someone would make fun of Americans? Why should we be offended?” -, surgida a partir do relato de uma anedota supostamente verdadeira (embora soasse mais como uma lenda, quase uma piada), desencadeou uma longa seqüência de comentários que, antes de simplesmente “estender” a discussão, ou ampliar o horizonte de argumentação, funcionou mais como a sedimentação de uma polaridade, isto é, o reforço de um discurso identitário em que um “nós” se opõe a um “eles" - por mais indistintos e anônimos que fossem os "rostos” (vozes) desses sujeitos. Em suma, o comentário, bem de acordo com a visão que Foucault propunha sobre esse mecanismo, aparecia ali para conjurar os efeitos potencialmente perigosos do discurso ou seja, para, sob a forma de uma aparente proliferação do discurso, “dominar [o] acontecimento aleatório, esquivar [a] pesada e temível materialidade” desse discurso (1971/1996: 8-9).

Apontei ainda em algumas análises o modo como a figura do autor é particularmente problematizada quando se trata de identificar de onde "surgem os discursos”, quem os assina, a quem interessa sua propagação. Reporto-me, nessa conexão, à análise do thread suscitado pela mensagem de “desagravo” aos imigrantes ilegais nos Califórnia (Capítulo 6, seção 1), assinada por um membro da lista até então desconhecido mas cuja intervenção deixou marcas sensíveis ao longo de toda a discussão subseqüente. Ora, observa-se ali, naquela mensagem, a reativação de discursos já-ditos, mas também o espectro de discursos não-ditos - ou "esquecidos” na memória discursiva - que dispensariam uma assinatura individualizada. É como se os contra-discursos, os argumentos pró e contra, inscritos em formações discursivas concorrentes - “os americanos são legais, mas não bobos”, "nem os negros secaram o poço [como os mexicanos o fazem]" (ditos no texto), ou “os americanos são tolerantes demais e estão pagando por isso", "mas os americanos deveriam reconhecer a dívida ancestral que têm para com esses povos imigrantes” (não ditos no texto), para citar alguns dos enunciados formuláveis - já estivessem contidos ali em seu germe, prontos 
para emergir na superfície material de uma prática ${ }^{62}$. É como se o que fosse dito depois daquela mensagem tivesse necessariamente que se posicionar em um dos lados da trincheira. O desejo expresso por alguns dos comentadores de que esse "autor original” retornasse ao thread, que “desse as caras” para responder aos argumentos por eles levantados - o que, como vimos, nunca aconteceu - nada mais seria, acredito, do que a manifestação do desejo (recalcado) de atribuir um "rosto”, uma identidade a um discurso que comportava desde sempre, dentro de si, as posições subjetivas concorrentes com que ele haveria de dialogar: posições situáveis de um extremo a outro do espectro ideológico que o tema da presença (invasiva, não-desejada) do "outro" poderia mobilizar. Autor original, sim, pelas condições imediatas da situação enunciativa, mas antes de mais nada, autor anônimo, constituído heterogeneamente, atravessado inescapavelmente pela ação do interdiscurso e pelos mecanismos (parcialmente) inconscientes da subjetivação.

Retomando nosso percurso, foi no Capítulo 2 que pudemos desenvolver teoricamente o eixo principal de argumentação deste trabalho - a lembrar, a tensão dialética entre estrutura e acontecimento que se encontra no cerne das práticas discursivas analisadas. Uma investigação inicial em teorias da história, psicologia e filosofia acerca do papel central da narrativa (forma discursiva estruturada de elaboração da experiência humana) nos permitiu chegar à consideração das lendas urbanas como uma forma particular de narrativas interpretável em sua historicidade isto é, como estando atrelada simultaneamente às intrigas convencionais (sóciohistórico-culturalmente construídas) de uma canonicidade e às instâncias eventuais (condições singulares do acontecimento) de sua produção. Na esteira dessa primeira investigação, que inclui a contribuição de um aporte teórico vindo da antropologia e das teorias pós-estruturalistas e do discurso, todo um caminho nos conduziu à conclusão de que a tensão entre estrutura e acontecimento sustenta desde a própria tentativa de definição do gênero lenda, passando pelos mecanismos e procedimentos de autoregulação dos discursos que acabamos de relembrar, até a própria dinâmica do processo de construção de sentido e de identidade(s) promovido pela troca de mensagens sobre lendas urbanas em uma comunidade virtual em particular. Acredito que as análises, em

\footnotetext{
${ }^{62}$ Dentro dessa perspectiva, remeto à postulação da Análise do Discurso inspirada em Pêcheux, segundo a qual "[a]s condições de produção de um discurso determinariam a situação enunciativa vivida pelo sujeito como efeito das relações do lugar por ele ocupado numa dada FD [formação discursiva], e desta dependeriam, ao menos em parte, os sentidos atribuídos a este ou àquele texto" (Coracini 2007: 32).
} 
especial as do Capítulo 5 - todo ele dedicado ao jogo entre o "novo” e o "velho" nas lendas - e as do Capítulo 6 - sobre o outro personificado - terão fornecido exemplos suficientes dos diversos modos em que aquela tensão fundante se concretiza, o que dispensaria aqui uma recapitulação.

Faltava, porém, enveredarmos pelas trilhas sinuosas com as quais a questão da verdade nas/das lendas nos confrontava. Foi assim que reservei todo um capítulo para essa discussão - tarefa que exigiu uma investigação em um campo de saber filosófico com o qual tinha pouca familiaridade, mas cuja contribuição se revelou fundamental e cujo estudo provou, pessoalmente, ser de grande prazer e interesse. Nesse capítulo vimos como, do ponto de vista da filosofia de Heidegger, a busca pela verdade está determinada pela condição de errância dos indivíduos (entes), os quais, por natureza, esquecem-se de que sua imersão na cotidianidade, na dimensão do mundano, implica um afastamento da autenticidade do Ser e, portanto, do acesso à verdade das coisas. Vimos também como, semelhantemente para Nietzsche e Foucault, a verdade não se encontra como dado do universo a ser revelado mas, antes, como resultado da ação do homem, da construção interpretativa - sempre contingente - da realidade, que se dá via linguagem e na forma de uma vontade de verdade. E, finalmente, vimos que, de acordo com uma visão pragmatista da questão, a verdade é tida como o produto de usos (jogos) que o homem faz com a linguagem, sendo essa verdade circunscrita aos termos das práticas historicamente situadas de sua produção. Embora de perspectivas distintas, tais abordagens filosóficas se prestam bastante bem ao entendimento do processo discursivo que constitui as lendas urbanas, uma vez que todas elas apontam, de uma certa maneira, para o elemento ficcional - isto é, de elaboração narrativa, ou armação-em-intriga, para lembrar ainda Ricoeur - que subjaz toda a discussão sobre a busca da verdade, a veracidade, a verossimilhança e a plausibilidade do discurso das e sobre as lendas. Creio que isso terá sido possível contemplar não só nas análises sobre as lendas ao redor do furacão Katrina, conduzidas no Capítulo 3, mas também em análises posteriores, como, por exemplo, as que giram em torno da AIDS, propostas no Capítulo 5.

A essas últimas, poderíamos ainda acrescentar, em vista de tais reflexões teóricas, que a busca pela verdade nas/das lendas urbanas impõe-se como questão relevante a partir de pelo menos dois pontos de vista imbricados. O primeiro é o de que não se conhecem ainda os "fatos" ou "toda a verdade” sobre a doença, isto é, não se sabe/sabia ainda - assim como no advento das "novas" tecnologias do cotidiano e das 
novas técnicas de pesquisa genética, aliás (Capítulo 4, seção 2 e Capítulo 6, seção 3) - o que é fato suficientemente estabelecido (comprovado, científico) e o que é simplesmente boato ou desinformação (estes, sempre insistentes, difíceis de dissipar) e, portanto, erra-se, age-se no apego às verdades mais “essenciais” e “mundanas”: a de que vamos todos morrer, queiramos ou não, ou a de que estamos sujeitos a perigos imponderáveis, ainda não inteiramente decifráveis. O segundo ponto de vista é o de que os fatos, ainda que incompletos, controversos, ou apenas "plausíveis”, só fazem sentido na medida em que se vinculam a um regime de verdade, isto é, são mediados por um regime de práticas discursivas que têm na narrativa uma forma privilegiada de realização - a narrativa de um tipo particular, dispersa e multiforme, que é a lenda urbana, mas também outras narrativas de um tipo particular, que são as narrativas “institucionais” (leia-se: saberes/poderes legitimados) da ciência, da medicina, da mídia. Em termos bem sucintos, poderíamos reunir esses dois pontos de vista sob a forma de (mais) uma tensão dialética: a vontade de verdade na lenda urbana se configura, a um só tempo, como forma de auto-regulação e recriação ficcional (armação-em-intriga) das apreensões, medos e ansiedades da vida cotidiana via discurso. Ou, em termos ilustrativos, “dando voz aos donos da prática”, poderíamos recuperar uma mensagem enviada por Mr. Calvin (ver Capítulo 1, seção 2.1.1), membro assíduo da lista de discussão que, num momento de auto-reflexividade, responde da seguinte maneira ao questionamento de um novato sobre a qualidade do material ali publicado:

[Rumores, lendas e outras tais formas de folclore urbano] são submetidas à lista não para perpetuação, mas como fomento para o nosso interesse. O participante (poster) provavelmente se dá conta da qualidade espúria do material e presume que tal qualidade torna-o mais adequado como uma contribuição, nem mais nem menos. É improdutivo presumir que o material é postado aqui porque é verdadeiro; nós deveríamos presumir que ele é postado simplesmente porque estabelece uma identificação (it relates). Assim, participantes como você têm a chance de falar sobre ele. Para você, o interesse é em desbancá-lo, e foi o que você fez. Pois muito bem! Mas essa ação secundária nos teria sido negada, para começo de conversa, se a informação não nos tivesse sido apresentada.” (in: VIRUS (yeah,right), 20/8/2005, grifos meus) 
Eu ressaltaria, por fim, uma última dimensão em que a tensão estruturaacontecimento se opera, a qual foi possível contemplar mais claramente nos capítulos de análise. Trata-se do modo como o velho e o novo, o arquivado e o por arquivar se interpenetram, criando narrativas híbridas que se metamorfoseiam em múltiplas modalidades; o modo como estas se confundem com notícias sensacionalistas, se embaralham às controvérsias e debates científicos e se imiscuem no anedotário e na sabedoria populares; enfim, a forma como elas articulam criativamente - posto que são narrativas - as ansiedades, medos e questões perenes que habitam o imaginário de uma sociedade fragmentada à qual pertencemos todos. E aí se destacaram, em particular, o medo da contaminação (em suas diversas formas) e a obsessão em torno da (falta) de segurança - exemplos dos quais bastaria lembrar as histórias ao redor da celebração do Halloween (Capítulo 5, seção 3), ou ainda as lendas envolvendo o rapto de crianças e o uso de células-tronco (Capítulo 6, seção 3).

A propósito, como este pesquisador, acometido de um mal de arquivo, não deixou de colecionar material sobre lendas urbanas até este pleno momento de conclusão de trabalho, não poderia deixar de mencionar a curiosa e emblemática mensagem que chega à minha caixa de e-mail em 28 de maio de 2007. Intitulada simplesmente Stem Cells, ela remete a um editorial publicado no jornal Boston Herald poucos dias antes dando conta de um rumor ("story going around town - one now verging on urban myth”) segundo o qual um restaurante tailandês no bairro de Allston, em Boston, estaria abrigando num dos refrigeradores de seu porão uma quantidade de recém-criados lotes de células-tronco (stem cell lines). Logo de início, o editorialista ecoa nossa discussão sobre a verdade das lendas, com a seguinte proposição: "Perhaps it doesn't matter whether there's any truth to the story, because like most myths it tells a larger truth - in this case one about the absurd lengths to which scientists must go to comply with the federal red tape around the issue of stem cell research”. Ora, em vista de todo o percurso traçado até aqui, é impossível deixar de ver nesse rumor um testemunho claro da adaptabilidade aparentemente infindável das lendas contemporâneas - mas adaptabilidade sempre limitada, enfim, e em última instância, por se associarem a um imaginário, a modalidades arquivadas (e portanto disponíveis) de elaboração da experiência em sociedade. Não por acaso, o relato reúne pelo menos três dos temas visitados neste trabalho: a alimentação e seus possíveis riscos - no caso, trata-se de um restaurante tailandês -, a ciência e os “mitos” que ela engendra - o uso 
ainda bastante controverso de células-tronco - e, obviamente, a presença suspeita do outro estrangeiro - aqui, simbolizado pela nacionalidade do restaurante.

Talvez a "verdade maior" sobre a lenda urbana como forma simbólica possa ser formulada nos seguintes termos: ela é marca, traço ou sintoma que, por meio do discurso, aponta para o desejo de conjurar o acaso, de dar sentido à percepção vaga e generalizada de insegurança e falta de controle sobre os "riscos" que enfrentamos. O desejo, enfim, de suspender, ainda que por um breve instante, a errância da vida nas sociedades contemporâneas. 


\section{BIBLIOGRAFIA}

\section{a) Referências bibliográficas:}

ACHARD, Pierre (1983/1999) “Memória e produção discursiva do sentido”, in: ACHARD, Pierre (et al.) Papel da Memória. Campinas: Pontes.

ALLEN, Barry (1995) Truth in Philosophy. Cambridge \& London: Harvard University Press.

ARISTÓTELES (s/d) Arte Retórica e Arte Poética. Rio de Janeiro: Ediouro.

ARROJO, Rosemary (1992) “A desconstrução do signo e a ilusão da trama”, in: ARROJO, Rosemary (org.) O Signo Desconstruído. Campinas: Pontes.

BAKHTIN, Mikhail (1934-5/1990) “O discurso no romance”, in: Questões de Literatura e Estética. São Paulo: Editora da UNESP/Hucitec, $2^{a}$ edição. (1952-3/2000) “Os Gêneros do Discurso”, in: Estética da Criação Verbal. São Paulo: Martins Fontes, $3^{\text {a }}$ edição.

BARTHES, Roland (1966/2003) "Estrutura da notícia”, in: Crítica e Verdade. São Paulo: Perspectiva.

Rumor da Língua. São Paulo: Martins Fontes.

(1971/2004) “Escritores, intelectuais, professores”, in: $O$

BAUDRILLARD, Jean (1990/1996) A Transparência do Mal - Ensaio sobre os Fenômenos Extremos. Campinas: Papirus, $3^{\mathrm{a}}$ edição.

BAUMAN, Zygmunt (1998) O Mal-Estar na Pós-Modernidade. Rio de Janeiro: Jorge Zahar Editor.

(2003) Comunidade - A Busca por Segurança no Mundo Atual. Rio de Janeiro: Jorge Zahar Editor.

(2004) Identidade. Rio de Janeiro: Jorge Zahar Editor.

BBC News (2004) “Nigerian Scammers in Line of Fire”. Entrevista de Nuhu Ribadu a Tracey Logan, in: http://news.bbc.co.uk/go/pr/fr//2/hi/technology/3526209.stm, 3 de março de 2004. Acessada em 1/2/2007.

BENJAMIN, Walter (1936/1987) “O Narrador - Considerações sobre a obra de Nikolai Leskov”, in: Obras Escolhidas: Magia e Técnica, Arte e Política. São Paulo: Brasiliense. 
BIRD, S. Elizabeth. (2002) "It Makes Sense to Us: Cultural Identity in Local Legends of Place”, in: Journal of Contemporary Etnography, vol. 31, no.5, pp. 519547. London: Sage Publications.

BLACKBURN, Simon (2006) Verdade - Um Guia para os Perplexos. Rio de Janeiro: Civilização Brasileira.

BOSTON HERALD (2007) "Stem Cell Dilemma a Job for Congress", in: http://news.bostonherald.com/editorial, 22 de maio de 2006. Editorial. Acessado em 28/5/2007.

BOUTOT, Alain (1991) Introdução à Filosofia de Heidegger. Mira-Sintra, Mem Martins: Publicações Europa-América. Médicas.

BRUNER, Jerome (1990/1997) Atos de Significação. Porto Alegre: Artes (1996/2001) “A interpretação narrativa da realidade”, in: A Cultura da Educação. Porto Alegre: Artes Médicas.

BRUNVAND, Jan Harold (1981) The Vanishing Hitchhicker - American Urban Legends \& Their Meanings. New York: W.W. Norton \& Company.

Urban Legends. New York: W.W. Norton \& Company. (1999) Too Good to Be True - The Colossal Book of (2001) The Truth Never Stands in the Way of a Good Story. Urbana \& Chicago: University of Illinois Press.

W.W. Norton \& Company. (2002) Encyclopedia of Urban Legends. New York:

BURGESS, Adam (2004) Cell Phones, Public Fears, and a Culture of Precaution. Cambridge: Cambridge University Press.

CAMPION-VINCENT, Véronique \& RENARD, Jean-Bruno (2002) De Sources Sûres - Nouvelles rumeurs d'aujourd'hui. Paris: Payot.

CARR, David (2005) "More Horrible Than Truth: News Reports”, in: The New York Times online, www.nytimes.com, 19 de setembro de 2005. Acessado em 17/9/2006.

CERTEAU, Michel de (1974/1995) A Cultura no Plural. Campinas: Papirus. História. Rio de Janeiro: Forense Universitária. (1975/1982) "Fazer História", in: A Escrita da (1980/1988) The Practice of Everyday Life. Berkeley \& Los Angeles: University of California Press. 
CLARK, Maudemarie (1990/1998) Nietzsche on Truth and Philosophy. Cambridge: Cambridge University Press.

CORACINI, Maria José (2007) "Pêcheux hoje: no limiar das dúvidas e (in)certezas”, in: A Celebração do Outro: Arquivo, Memória e Identidade - Línguas (Materna e Estrangeira), Plurilingüistmo e Tradução. Campinas: Mercado de Letras.

CRUICKSHANK, Douglas (2001) "I crave your distinguished indulgence (and all your cash)”, in: Salon.com, http://archive.salon.com, 7 de agosto de 2001. Acessado em 31/1/2007.

DAMON, Dan (2004) “Turning the Tables on Nigeria's E-Mail Conmen”, in: BBC News, http://news.bbc.co.uk/2/hi/africa/3887493.stm, 13 de julho de 2004. Acessado em 1/2/2007.

DAUPHIN, Florian (2002) "Rumeurs électroniques: synergie entre technologie et archaïsme”, in: Sociétés n 76, pp. 71-87.

DÉGH, Linda (2001) Legend and Belief - Dialectics of a Folklore Genre. Bloomington: University of Indiana Press.

DELEUZE, Gilles (1988) Foucault. São Paulo: Editora Brasiliense.

DE NARDI, Fabiele Stockmans (2004) "Entre a estrutura e o acontecimento: Uma releitura de Pêcheux e Foucault em busca do sistema”, in: www.discurso.ufrgs.br, acessado em 13/9/2005.

Perspectiva.

DERRIDA, Jacques (1967/2002) A Escritura e a Diferença. São Paulo: Editora (1972/2001a.) “Assinatura Acontecimento Contexto”, in: Margens da Filosofia. Campinas: Papirus.

(1972/2001b.) Posições. Belo Horizonte: Autêntica.

Iluminuras.

(1972/2005) A Farmácia de Platão. São Paulo:

Rio de Janeiro: Relume Dumará.

(1992) Acts of Literature. New York e London: Routledge.

(1995/2001) Mal de Arquivo - Uma Impressão Freudiana.

ELLIS, Bill (2001) Aliens, Ghosts, and Rituals - Legends We Live. Jackson: University Press of Mississsippi.

FABRÍCIO, Branca Falabella (2006) "Narrativização da experiência: o triunfo da ordem sobre o acaso”, in: MAGALHÃES, Isabel; GRIGOLETTO, Marisa e CORACINI, Maria José (orgs.) Práticas Identitárias - Língua e Discurso. São Carlos: Claraluz. 
FEARS, Darryl (2005) "Study: Many blacks cite AIDS conspiracy”, in: The Wahington Post online, http://www.washingtonpost.com/wp-dyn/articles/A336952005Jan24.html, 25 de janeiro de 2005. Acessado em 8/2//2007.

FERNBACK, Jan (2003) "Legends on the Net: An Examination of OnlineMediated Communication as a Locus of Popular Culture”, in: New Media \& Society, vol. 5 (1), pp. 29-45. London: Sage Publications.

FINE, Gary Alan (1992) Manufacturing Tales. Sex and Money in Contemporary Legends. Knoxville: The University of Tennessee Press.

FINE, Gary Alan \& TURNER, Patricia A. (2001) Whispers on the Color Line Rumor and Race in America. Berkeley, Los Angeles \& London: University of California Press.

FOUCAULT, Michel (1969/2004) A Arqueologia do Saber. Rio de Janeiro e São Paulo: Forense Universitária, $7^{\mathrm{a}}$ edição.

edição. (1971/1996) A Ordem do Discurso. São Paulo: Loyola, $3^{a}$ Martins Fontes. (1975-6/1999) Em Defesa da Sociedade. São Paulo: (1976/1999) História da Sexualidade 1 - A Vontade de Saber. Rio de Janeiro: Graal, $13^{\mathrm{a}}$ edição. (1979/1996) Microfísica do Poder. Rio de Janeiro: Graal, $12^{\mathrm{a}}$ edição. (1997) Resumo dos Cursos do Collège de France (19701982). Rio de Janeiro: Jorge Zahar Editor.

FULFORD, Robert (1999) The Triumph of Narrative - Storytelling in the Age of Mass Culture. New York: Broadway Books.

GALLO, Ricardo (2006) "Embalagem leva Idec a notificar redes de fast-food”, in: Folha de S. Paulo online, www.folha.uol.com.br/folha/cotidiano/, 29 de novembro de 2006. Acessado em 30/11/2006.

GALVÃO, Vinícius Queiroz (2006) “Nova York proíbe venda de alimentos com gordura trans”, in: Folha de S. Paulo, Caderno Mundo, p. A16, 6 de dezembro de 2006.

GENGE, N. E. (2000) Urban Legends - The As-Complete-As-One-Could-Be Guide to Modern Myths. New York: Three Rivers Press.

GHIRALDELLI Jr., Paulo (2001) Neopragmatismo e Verdade - Rorty em Conversação com Davidson e Habermas. Tese de doutoramento. São Paulo: FFLCH, USP. 
GLASSNER, Barry (1999/2003) Cultura do Medo. São Paulo: Francis.

GOLDSTEIN, Diane E. (2004) Once upon a Virus - AIDS Legends and Vernacular Risk Perception. Logan: Utah State University Press.

GREGOLIN, Maria do Rosário (2004) Foucault e Pêcheux na Análise do Discurso - Diálogos e Duelos. São Carlos: Claraluz.

(2005) "Nas malhas da mídia: Agenciando os gêneros, produzindo sentidos”, in: BARONAS, Roberto Leiser (org.) Identidade Cultural e Linguagem. Cáceres: Unemat Editora; Campinas: Pontes.

GRIGOLETTO, Marisa (2002) A Resistência das Palavras. Campinas: Editora da Unicamp.

GRILLO, Sheila Vieira (2004) A Produção do Real em Gêneros do Jornal Impresso. São Paulo: Humanitas.

edição.

HEIDEGGER, Martin (1927/1995) Ser e Tempo - Parte I. Petrópolis: Vozes, $5^{\text {a }}$ (1930/1961) “On the Essence of Truth”, $4^{\text {th }}$ edition translated by John Sallis, in: http://foucault.info/links/related-heidegger, acessado em 25/8/2006.

HERZOG, Werner (1999) “Lessons of Darkness”, in: www.wernerherzog.com, acessado em 11/8/2006.

HILL, Matthew (2006) "The babies who are murdered to order", in: http://www.thisislondon.co.uk/news, 15 de dezembro de 2006. Acessado em 25 de abril de 2007.

KRISTEVA, Julia (1991) Strangers to Ourselves. New York: Columbia University Press.

LEONG, Melissa (2005) "Hoax e-mail makes Toronto women fearful”, in: National Post online, www.canada.com/nationalpost/story, 2 de dezembro de 2005. Acessado em 6/12/2006. Barcarolla.

LIPOVETSKY, Gilles (2004) Os Tempos Hipermodernos. São Paulo:

LOPES, Carlos Renato (2005) "Lendas Urbanas: Discurso, Cotidiano e Verdade”, in: Revista da ANPOLL no. 19, pp. 33-56. Campinas: Universidade Estadual de Campinas.

LOPES, Juliana (2001) “Tive de crescer na marra”. Entrevista com Daniela Sarahyba, in: IstoÉ Gente online, http://www.terra.com.br/istoegente/114/entrevista/, 8 de outubro de 2001. Acessado em 30/11/2006. 
LYOTARD, Jean-François (1979/1997) The Postmodern Condition: A Report on Knowledge. Minneapolis: The University of Minnesota Press.

(1986/1993) O Pós-Moderno Explicado às Crianças.

Lisboa: Publicações Dom Quixote, $2^{\mathrm{a}}$ edição.

MAFFESOLI, Michel (2004/2007) O Ritmo da Vida - Variações sobre o Imaginário Pós-moderno. Rio de Janeiro e São Paulo: Record.

MAINGUENEAU, Dominique (1984/2005) Gênese dos Discursos. Curitiba: Editora Criar.

MALDIDIER, Denise (1989/2003) A Inquietação do Discurso - (Re)Ler Michel Pêcheux Hoje. Campinas: Pontes.

MARCONDES, Danilo (1997/2005) Iniciação à História da Filosofia. Rio de Janeiro: Jorge Zahar Editor.

MOSÉ, Viviane (2005) Nietzsche e a Grande Política da Linguagem. Rio de Janeiro: Civilização Brasileira.

NBC 4-TV (2005) "Black Leaders Call on Feds to Probe Internet Rumor About Racial Attacks”, in: http://www.knbc.com/education/4463872/detail.html, 8 de maio de 2005. Acessado em 12/4/2007.

NIETZSCHE, Friedrich (1873/1987) "Sobre a verdade e a mentira no sentido extra-moral”, in: Os Pensadores - Nietzsche Volume 1. São Paulo: Nova Cultural.

OLSON, Nate (2001) "Perspectivism and Truth in Nietzsche’s Philosophy: A Critical Look at the Apparent Contradiction", in: http//www.stolaf.edu/depts/philosophy/, acessado em 15/9/2006.

ORLANDI, Eni (1983/1987) A Linguagem e seu Funcionamento - As Formas do Discurso. Campinas: Pontes, $2^{\mathrm{a}}$ edição revista e aumentada.

Sentidos. Campinas: Pontes.

(2001) Discurso e Texto - Formulação e Circulação de

PÊCHEUX, Michel (1983/1997) O Discurso - Estrutura ou Acontecimento. Campinas: Pontes, $2^{\mathrm{a}}$ edição.

(et. al.) Papel da Memória. Campinas: Pontes.

(1983/1999) “Papel da memória”, in: ACHARD, Pierre

PINHEIRO, Narjara Ferrari (2002) "A noção de gênero para análise de textos midiáticos”, in: MEURER, José Luiz e MOTTA-ROTH, Desirée (orgs.) Gêneros Textuais. Bauru: EDUSC.

POSSENTI, Sírio (2002) Os Limites do Discurso. Curitiba: Criar Edições. 
POSSENTI, Sírio (2004) “Teoria do Discurso: um caso de múltiplas rupturas”, in: MUSSALIN, Fernanda e BENTES, Anna Christina (orgs.) Introdução à Lingüística - Fundamentos Epistemológicos. Volume 3. São Paulo: Cortez Editora.

QUATROCANTOS.COM. www.quatrocantos.com./LENDAS/INDEX.HTM

RÉE, Jonathan (2000) Heidegger - História e Verdade em Ser e Tempo. São Paulo: Editora da Unesp.

RENARD, Jean-Bruno (1994) "Entre faits divers et mythes: les légendes urbaines”, in: Religiologiques, no. 10, automne, pp. 101-109.

3e édition.

(1999/2006) Rumeurs et Légendes Urbaines. Paris: PUF, RICOEUR, Paul (1983/1994) Tempo e Narrativa - Tomo I. Campinas: Papirus.

Papirus. (1984/1995) Tempo e Narrativa - Tomo II. Campinas: Papirus. (1985/1997) Tempo e Narrativa - Tomo III. Campinas:

ROEPER, Richard (2002) Urban Legends - The Truth Behind All Those Deliciously Entertaininig Myths That Are Absolutely, Positively, 100\% Not True. Franklin Lakes: New Page Books.

RORTY, Richard (1989/1994) Contingência, Ironia e Solidariedade. Lisboa: Editorial Presença.

Cambridge University Press.

(1991/1999) Objectivity, Relativism, and Truth. Cambridge: (1998/2005) Verdade e Progresso. Barueri: Manole.

ROUDINESCO, Elisabeth (2001/2006) A Análise e o Arquivo. Rio de Janeiro: Jorge Zahar Editor.

SAHLINS, Marshall (1981) Historical Metaphors and Mythical Realities. Ann Harbor: The University of Michigan Press.

Rio de Janeiro: Jorge Zahar Editor. (1985/1990) "Estrutura e história”, in: Ilhas de História.

SAN FRANCISCO CHRONICLE (2005) "Cost of the finger hoax", in: www.sfgate.com, p. b-6, 26 de abril de 2005. Editorial. Acessado em 15/11/2006.

SCHLOSSER, Eric (2002) Fast Food Nation - The Dark Side of the AllAmerican Meal. New York: Perennial. 
SEGATTO, Cristiane (2007) “A batalha das células-tronco”, in: Época, 23 de abril de 2007, p. 83.

SILVA, Tomaz Tadeu da (2000) “A produção social da identidade e da diferença”, in: SILVA, Tomaz Tadeu da (org.) Identidade e Diferença. Petrópolis: Editora Vozes, $5^{\mathrm{a}}$ edição.

SMART, Barry (1996) “Teoria social pós-moderna”, in: TURNER, Bryan S. (ed.) Teoria Social. Lisboa: Difel.

SNOPES.COM. Urban Legends Reference Page. www.snopes.com

SOARES, Rosana de Lima (2001) Imagens Veladas - Aids, Imprensa e Linguagem. São Paulo: Annablume.

SOUZA, Lynn Mario T. M. de (2004) “Hibridismo e Tradução Cultural em Bhabha”, in: ABDALA JUNIOR, Benjamin (org.) Margens da Cultura. São Paulo: Boitempo Editorial.

STEIN, Ernildo (1993) Seminário sobre a Verdade. Petrópolis: Vozes.

SULLIVAN, Mike (2006) "Ex tells of HIV nightmare”, in: The Sun online, http://www.thesun.co.uk/article/0,2-2006280282,2.html, 20 de junho de 2006. Acessado em 14/2/2007.

SZCZEPANSKA, Anna Maria (2001) "Searching for the Virtual Community", in: Proceedings of the 24th Information Systems Research Seminar in Scandinavia, Norway.

TAÏEB, Emmanuel (2001) "Persistance de la rumeur - Sociologie des rumeurs électroniques”, in: Réseaux, Hermès Sciences, n 106, pp. 233-272.

THE ECONOMIST (2005) “Anatomy of a Techno-Myth”, in: www.economist.com/science, 23 de março de 2005. Acessado em 1/12/2006.

THENONPROFITS.COM (s/d) "Tips on Staying Safe... for Women”, in: www.thenonprofits.com/safety.htm. Acessado em 7/12/2006. Press.

TRUBSHAW, Bob (2002) Explore Folklore. Loughborough: Heart of Albion

URBANLEGENDS.ABOUT.COM. Urban Legends and Folklore Guide, http://urbanlegends.about.com/

VOS, Gail de (1996) Tales, Rumors, and Gossip - Exploring Contemporary Folk Literature in Grades 7-12. Englewood: Libraries Unlimited, Inc. 
WAELHENS, Alphonse de \& BIEMEL, Walter (1948) “Introduction” à la traduction de HEIDEGGER, Martin. De l'essence de la verité. Louvain: E. Nauwelaerts Éditeur; Paris: Joseph Vrin Éditeur.

WHATLEY, Mariamne H. \& HENKEN, Elissa R. (2000) Did you Hear About the Girl Who...? - Contemporary Legends, Folklore, and Human Sexuality. New York \& London: New York Univerisity Press.

WHITE, Hayden (1978/1994) Trópicos do Discurso - Ensaios sobre a Crítica da Cultura. São Paulo: Edusp.

(1987) The Content of the Form: Narrative Discourse and Historical Representation. Baltimore: Johns Hopkins University Press.

WIKIPEDIA (The Free Encyclopedia) (s/d) "Daniela Sarahyba", in: http://pt.wikipedia.org/wiki/Daniella_Sarahyba, acessado em 30/11/2006.

WILLIAMS, Rachel (2005) “Mobile Dangers at Petrol Stations Dismissed”, in: The Scotsman online, http://news.scotsman.com/latest.cfm?id=4287216, 20 de março de 2005. Acessado em 1/12/2006.

ZIZEK, Slavoj (2005) “Sobre homens e lobos”, in Folha de S. Paulo, Caderno Mais, p. 3, 23 de outubro de 2005.

\section{b) Obras consultadas:}

ARROJO, Rosemary \& RAJAGOPALAN, Kanavillil (1992) “A noção de literalidade: metáfora primordial”, in: ARROJO, Rosemary (org.) O Signo Desconstruído. Campinas: Pontes.

AUTHIER-REVUZ, Jacqueline (2004) Entre a Transparência e a Opacidade: Um Estudo Enunciativo do Sentido. Porto Alegre: EDIPUCRS.

BAKHTIN, Mikhail (Volochinov) (1929/1997) Marxismo e Filosofia da Linguagem. São Paulo: Hucitec, 8 a edição.

BARRETT, Michèle (1991) The Politics of Truth - from Marx to Foucault. Cambridge: Polity Press.

BARROCO, Michel \& FAYOLLE, Vincent (2001) "Mondes Souterrains, Légendes Urbaines et Méta-Destination: Vers une Dynamique des Genres Narratifs”, in: Sociétés $n^{\circ} 73$, pp. 87-98.

BARTHES, Roland (1979) Lição. Lisboa: Edições 70. 
BENNETT, Gillian (1999) Alas, Poor Ghost! - Traditions of Belief in Story and Discourse. Logan: Utah StateUniversity Press.

BHABHA, Homi K. (1994/2003) O Local da Cultura. Belo Horizonte: Editora UFMG.

BOURDIEU, Pierre (1982/1998) A Economia das Trocas Lingüísticas. São Paulo: Edusp, $2^{\mathrm{a}}$ edição.

BRAIT, Beth (1997) "Bakhtin e a natureza constitutivamente dialógica da linguagem”, in: BRAIT, Beth (org.) Bakhtin, Dialogismo e Construção do Sentido. Campinas: Editora da UNICAMP.

BRANDÃO, Helena H. N. (1995) Introdução à Análise do Discurso. Campinas: Editora da Unicamp.

BURUMA, Ian \& MARGALIT, Avishai (2005) Occidentalism - The West in the Eyes of Its Enemies. London: Penguin Books.

CARMAN, Taylor (2006) "Heidegger on Truth”, in: www.essex.ac.uk/philosophy/tpn, acessado em 25/8/2006.

CHARAUDEAU, Patrick e MAINGUENEAU Dominique (2004) Dicionário de Análise do Discurso. São Paulo: Contexto.

CORACINI, Maria José (2006) “Identidades múltiplas e sociedade do espetáculo: impacto das novas tecnologias de comunicação", in: MAGALHÃES, Isabel; GRIGOLETTO, Marisa e CORACINI, Maria José (orgs.) Práticas Identitárias Língua e Discurso. São Carlos: Claraluz.

DERRIDA, Jacques (1982/1988) "Roundtable on Autobiography", in: The Ear of the Other. Lincoln e London: University of Nebraska Press.

Limited Inc. Campinas: Papirus.

(1991) “Em direção a uma ética da discussão”, Posfácio a

DIAS, Maria Odila Silva (1998) "Hermenêutica do Quotidiano na Historiografia Contemporânea”, in Projeto História - Trabalhos da Memória no. 17, 223-258. São Paulo: Educ e Fapesp.

FINE, Gary Alan \& TURNER, Patricia A. (2006) "Cultural myths behind Katrina whispers”, in: The Christian Science Monitor online, www.csmonitor.com, 4 de outubro de 2005. Acessado em 5/10/2006.

FOUCAULT, Michel (1973/2003) A Verdade e as Formas Jurídicas. Rio de Janeiro: PUC Rio e Nau Editora, $3^{\text {a }}$ edição.

GOMES, Mayra Rodrigues (2001) Repetição e Diferença nas Reflexões sobre Comunicação. São Paulo: Annablume. 
GREGOLIN, Maria do Rosário (2001) “Análise do Discurso: Os sentidos e suas movências”, in: GREGOLIN, Maria do Rosário; CRUVINEL, Maria de Fátima e KHALIL, Marisa Gama (orgs.) Análise do Discurso: Entornos do Sentido. Araraquara: UNESP e Cultura Acadêmica Editora.

GRIGOLETTO, Marisa (1992) “A desconstrução do signo e a ilusão da trama”, in: ARROJO, Rosemary (org.) O Signo Desconstruído. Campinas: Pontes.

HALBWACHS, Maurice (1990) A Memória Coletiva. São Paulo: Vértice.

HELLER, Agnes (1985) O Cotidiano e a História. Rio de Janeiro: Paz e Terra.

LE GOFF, Jacques (1990) História e Memória. Campinas: Editora da Unicamp.

MACHADO, Roberto (1979/1996) “Introdução - Por uma Genealogia do Poder”, in FOUCAULT, Michel. Microfísica do Poder. Rio de Janeiro: Graal, $12^{\mathrm{a}}$ edição.

edição.

(2002) Nietzsche e a Verdade. Rio de Janeiro: Graal, 2a

MAINGUENEAU, Dominique (1987/1997) Novas Tendências em Análise do Discurso. Campinas: Pontes, $3^{\mathrm{a}}$ edição.

MIDGLEY, Mary (2003) The Myths We Live By. London \& New York: Routledge.

MOTTER, Maria Lourdes (2001) Ficç̧ão e História: Imprensa e Construção da Realidade. São Paulo: Arte \& Ciência, Villipress.

MURILLO, Luis Felipe Rosado (2004) "Uma proposta de interface entre dois domínios da análise de discurso: a linha francesa e a sua relação com a teoria crítica do discurso", in: www.discurso.ufrgs.br, acessado em 26/5/2006.

ORLANDI, Eni (1999) Análise de Discurso - Princípios e Procedimentos. Campinas: Pontes.

PÊCHEUX, Michel (1975/1995) Semântica e Discurso - Uma Crítica à Afirmação do Óbvio. Campinas: Editora da UNICAMP, $2^{a}$ edição.

(1983/2001) “A análise de discurso: três épocas (1983)”, in: GADET, F. \& HAK, T. (orgs.) Por uma Análise Automática do Discurso - Uma Introdução à Obra de Michel Pêcheux. Campinas: Editora da Unicamp, $3^{\mathrm{a}}$ edição.

PETERS, Michael (2000) Pós-estruturalismo e Filosofia da Diferença: Uma Introdução. Belo Horizonte: Autêntica.

RORTY, Richard (1979/1995) “A filosofia sem espelhos”, in: A Filosofia e o Espelho da Natureza. Rio de Janeiro: Relume Dumará, $2^{a}$ edição. 
RORTY, Richard (1991/1998) “Nietzsche, Sócrates e o Pragmatismo”, in: Cadernos Nietzsche $n^{\circ}$ 4. São Paulo: Discurso Editorial.

(1995/1999) Ensaios sobre Heidegger e Outros - Escritos Filosóficos 2. Rio de Janeiro: Relume-Dumará.

ROSE, Nikolas (2001) “Inventando nossos eus”, in ELLSWORTH, Elizabeth et. al. Nunca Fomos Humanos - Nos Rastros do Sujeito. Belo Horizonte: Autêntica.

SARUP, Madan (1993) An Introductory Guide to Post-Structuralism and Postmodernism. Athens: The University of Georgia Press.

SCHAFF, Adam (1978) História e Verdade. São Paulo: Martins Fontes.

SILVA, Franciso Paulo da (2004) “Articulações entre poder e discurso em Michel Foucault”, in: SARGENTINI, Vanice e NAVARRO-BARBOSA, Pedro (orgs.) M. Foucault e os Domínios da Linguagem. São Carlos: Claraluz.

SOUZA, Geraldo Tadeu (2002) Introdução à Teoria do Enunciado Concreto do Círculo de Bakhtin/Volochinov/Medvedev. São Paulo: Humanitas.

YARBROUGH, Stephen (1999) After Rhetoric - The Study of Discourse Beyond Language and Culture. Carbondale and Edwardsville: Southern Illinois University Press. 


\section{APÊNDICE A}

No Rastro de um Furacão - Capítulo 3, seção 2.1

Recebido em 1 de setembro de 2005:

\section{A physician writes from New Orleans}

Aug. 31, 2005

Thanks to all of you who have sent your notes of concern and your prayers. I am writing this note on Tuesday at 2 p.m.. I wanted to update all of you as to the situation here. I don't know how much information you are getting but I am certain it is more than we are getting. Be advised that almost everything I am telling you is from direct observation or rumor from reasonable sources.

They are allowing limited internet access, so I hope to send this dispatch today.

I am now a temporary resident of the Ritz Carleton Hotel in New Orleans. I figured if it was my time to go, I wanted to go in a place with a good wine list. In addition, this hotel is in a very old building on Canal Street that could and did sustain little damage. Many of the other hotels sustained significant loss of windows, and we expect that many of the guests may be evacuated here.

Things were obviously bad yesterday, but they are much worse today. Overnight the water arrived. Now Canal Street (true to its origins) is indeed a canal. The first floor of all downtown buildings is underwater. I have heard that Charity Hospital and Tulane are limited in their ability to care for patients because of water. Ochsner is the only hospital that remains fully functional. However, I spoke with them today and they too are on generator and losing food and water fast. The city now has no clean water, no sewerage system, no electricity, and no real communications. Bodies are still being recovered floating in the floods. We are worried about a cholera epidemic. Even the police are without effective communications. We have a group of armed police here with us at the hotel that is admirably trying to exert some local law enforcement.

This is tough because looting is now rampant. Most of it is not malicious looting. These are poor and desperate people with no housing and no medical care and no food or water trying to take care of themselves and their families. Unfortunately, the people are armed and dangerous. We hear gunshots frequently. Most of Canal street is occupied by armed looters who have a low threshold for discharging their weapons. We hear gunshots frequently. The looters are using makeshift boats made of pieces of styrofoam to access. We are still waiting for a significant national guard presence.

The health care situation here has dramatically worsened overnight. Many people in the hotel are elderly and small children. Many other guests have unusual diseases. ... There are (Infectious Disease) physicians in at this hotel attending an HIV confection. We have commandered the world famous French Quarter Bar to turn into an makeshift clinic. There is a team of about seven doctors and PAs and pharmacists. We anticipate that this will be the major medical facility in the central business district and French Quarter.

Our biggest adventure today was raiding the Walgreens on Canal under police escort. The pharmacy was dark and full of water. We basically scooped the entire drug sets into garbage bags and removed them. All under police excort. The looters had to be held back at gunpoint. After a dose of prophylactic Cipro I hope to be fine. In all we are faring well. We have set up a hospital in the the French Qarter bar in the hotel, and will start admitting patients today. Many will be from the hotel, but many will not. We are anticipating dealing with multiple medical problems, medications and and acute injuries. Infection and perhaps even cholera are anticipated major problems. Food and water shortages are imminent.

The biggest question to all of us is where is the National Guard. We hear jet fignters and 
helicopters, but no real armed presence, and hence the rampant looting. There is no Red Cross and no Salvation Army.

In a sort of cliché way, this is an edifying experience. One is rapidly focused away from the transient and material to the bare necessities of life. It has been challenging to me to learn how to be a primary care phyisican. We are under martial law so return to our homes is impossible.I don't know how long it will be and this is my greatest fear. Despite it all, this is a soul-edifying experience. The greatest pain is to think about the loss. And how long the rebuid will take. And the horror of so many dead people .

PLEASE SEND THIS DISPATCH TO ALL YOU THING MAY BE INTERSTED IN A DISPATCH from the front. I will send more according to your interest. Hopefully their collective prayers will be answered. By the way, suture packs, sterile gloves and stethoscopes will be needed as the Ritz turns into a MASH.

Recebido em 2 de setembro de 2005:

http://www.huffingtonpost.com/randall-robinson/new-orleans_b_6643.html

\section{New Orleans}

RETRACTION: The claim in the first sentence in my post was incorrect. I had been told this was happening, but these claims have turned out to be unsubstantiated. I therefore retract them -- but stand behind everything else I wrote without reservation.

It is reported that black hurricane victims in New Orleans have begun eating corpses to survive.

Four days after the storm, thousands of blacks in New Orleans are dying like dogs. No-one has come to help them.

I am a sixty-four year old African-American. New Orleans marks the end of the America I strove for.

I am hopeless. I am sad. I am angry against my country for doing nothing when it mattered.

This is what we have come to. This defining watershed moment in America's racial history. For all the world to witness. For those who've been caused to listen for a lifetime to America's ceaseless hollow bleats about democracy. For Christians, Jews and Muslims at home and abroad. For rich and poor. For African-American soldiers fighting in Iraq. For AfricanAmericans inside the halls of officialdom and out.

My hand shakes with anger as I write. I, the formerly un-jaundiced human rights advocate, have finally come to see my country for what it really is. A monstrous fraud.

But what can I do but write about how I feel. How millions, black like me, must feel at this, the lowest moment in my country's story.

Randall Robinson is a social justice advocate and author whose works include The Debt -What America Owes to Blacks. 


\section{APÊNDICE B}

The Nigerian Scam - Capítulo 5, seção 1

Recebido em 1 de abril de 2003:

DEAR SIR,

URGENT AND CONFIDENTIAL BUSINESS PROPOSAL

I AM MARIAM ABACHA, WIDOW OF THE LATE NIGERIAN HEAD OF STATE, GEN. SANI ABACHA. AFTER HE DEATH OF MY HUSBAND WHO DIED

MYSTERIOUSLY AS A RESULT OF CARDIAC ARREST, I WAS INFORMED BY OUR LAWYER, BELLO GAMBARI THAT, MY HUSBAND WHO AT THAT TIME WAS

THE PRESIDENT OF NIGERIA, CALLED HIM AND CONDUCTED HIM ROUND HIS APARTMENT AND SHOWED HIM FOUR METAL BOXES CONTAINING MONEY ALL IN FOREIGN EXCHANGE AND HE EQUALLY MADE HIM BELIEVE THAT THOSE BOXES ARE FOR ONWARD TRANSFER TO HIS OVERSEAS COUNTERPART FOR PERSONAL INVESTMENT.

ALONG THE LINE, MY HUSBAND DIED AND SINCE THEN THE NIGERIAN GOVERNMENT HAS BEEN AFTER US, MOLESTING, POLICING AND FREEZING OUR BANK ACCOUNTS AND EVEN MY ELDEST SON RIGHT NOW IS IN

DETENTION. MY FAMILY ACCOUNT IN SWITZERLAND WORTH

US\$22, $\$ 00,000.00$ AND 120,000,000.00 DUTCH MARK HAS BEEN

CONFISCATED BY THE GOVERNMENT. THE GOVERNMENT IS INTERROGATING HIM (MY SON MOHAMMED) ABOUT OUR ASSET AND SOME VITAL DOCUMENTS. IT WAS IN THE COURSE OF THESE, AFTER THE BURIAL RITE AND CUSTOMS, THAT OUR LAWYER SAW YOUR NAME AND ADDRESS FROM THE PUBLICATION OF THE NIGERIAN BUSINESS PROMOTION AGENCY. THIS IS WHY I AM USING THIS OPPORTUNITY TO SOLICIT FOR YOUR CO-OPERATION AND ASSISTANCE TO HELP ME AS A VERY SINCERE RESPONSIBLE PERSON. I HAVE ALL THE TRUST IN YOU AND I KNOW THAT YOU WILL NOT SIT ON THIS MONEY.

I HAVE SUCCEEDED IN CARRYING THE FOUR METAL BOXES OUT OF THE COUNTRY, WITH THE AID OF SOME TOP GOVERNMENT OFFICIAL, WHO STILL SHOW SYMPATHY TO MY FAMILY, TO A NEIGHBOURING COUNTRY (ACCRAGHANA) TO BE PRECISE. I PRAY YOU WOULD HELP US IN GETTING THIS MONEY TRANSFERRED OVER TO YOUR COUNTRY. EACH OF THESE METAL BOXES CONTAINS US $\$ 5,00 \odot, 00 \odot .0 \odot$ (FIVE MILLION UNITED STATES DOLLARS ONLY) AND TOGETHER THESE FOUR BOXES CONTAIN US20, $00 \odot, 000.00$ (TWENTY MILLION UNITED STATESDOLLARS ONLY). THIS IS ACTUALLY WHAT WE HAVE MOVED TO GHANA.

THEREFORE, I NEED AN URGENT HELP FROM YOU AS A MAN OF GOD TO HELP GET THIS MONEY IN ACCRA GHANA TO YOUR COUNTRY. THIS MONEY, AFTER GETTING TO YOUR COUNTRY, WOULD BE SHARED ACCORDING TO THE PERCENTAGE AGREED BY BOTH OF US.PLEASE NOTE THAT THIS MATTER IS STRICTLY CONFIDENTIAL AS THE GOVERNMENT WHICH MY LATE HUSBAND WAS PART OF IS STILL UNDER SURVAILLANCE TO PROBE US.

YOU CAN CONTACT ME THROUGH MY FAMILY LAWYER AS INDICATED ABOVE AND ALSO TO LIAISE WITH HIM TOWARDS THE EFFECTIVE COMPLETION OF THIS TRANSACTION ON TEL/FAX NO: $X X X-X-X X X X X X X$ AS HE HAS THE MANDATE OF THE FAMILY TO HANDLE THIS TRANSACTION.

THANKS AND BEST REGARD

MRS. MARIAM ABACHA 
Recebido em 26 de junho de 2003:

FROM: RICHARD MBEKI
E-MAIL:richardmbeki@Netscape.net

Naturally, this letter will come to you as a surprise since we have not met, permit me however, I am MR. RICHARD MBEKI, the son of late Mr. James MBEKI a Zimbabwean Farmer.

I am contacting you as the need for me to have a foreign business partner in your country has become necessary due to the present political instability in my country (Zimbabwe), does not encourage financial investment as the environment is not conducive for investment and most of all security is not guaranteed, just as reported by the International media. This problem started when the Zimbabwean government under the leadership of President Robert Mugabe announced a decree on May 31st 2001 to seize more than 6000 white-owned farms. So far, more than 5,400 white owned farms have been invaded, properties confiscated and farm lands seized. During these periods, as reported by the international media and C.N.N, more than 500 white farmers were killed; the government didn't stop at this, as just recently the governments have asked all white-farmers to give up their farms to black farmers or risk going to prison. Having lived in this country (Zimbabwe) for more than 30 years, I have no other country to go to, nor can I trace any of my distant relatives.

Therefore, I decided to contact you through my local Zimbabwean chamber of commerce for your assistance so that you can help me to establish a company in your country and later relocate there. Also, to front for me the kind of profitable business, since you known that I can not be able to travel out of the Nederland for the next two year.

Before the killing of my late father by the government troop because he was supporting the white farmer, he has deposited in a Security company based in Amsterdam (the Netherlands) the sum of USD20, 500,000.00 (Twenty million, five hundred United States Dollars) and make me as the next of kin, also the documents regards to the deposit was given to me, These funds was packaged in two boxes and declared as personal effects and photographic materials so as to avoid detection by immigration/security officials. For now, I stay in the Assylum house in the Nederland because Zimbabwe is highly unsafe for me and my family. You can also mail your immediate response to me.

Let me use this opportunity to also inform you that this transaction is $100 \%$ risk free and genuine and should be handled in the most confidential manner. This proposal is Not and most Not be linked to all the numerous scam letter flying around .The $(\$ 20.5 \mathrm{~m})$ already in the two boxes could be termed as consignment and I will not hesitate to link you to my late father safe contact in the security company for further discussion.

Upon your immediate response, I will immediately send to you all the documentation that will empower you to stand as the rightful beneficiary to the consignments in order for you to finalizing the transaction with the security company in the Netherlands

Lest I forget, you should be entitled to $25 \%$ of the total funds for your support and cooperation in the transaction. It's also your duty to assist me in investing my own share of the money in your company or in your country. I shall be counting on your unalloyed trust and immediate response.

Best Regards

MR. Richard Mbeki 